\title{
الأجهور الهانزة
}

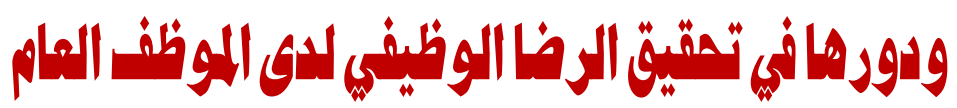
يِّ النظامسين الإداري الوضعي

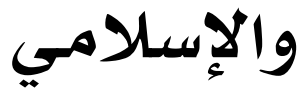

\author{
إعداد \\ د. صبري جلبي أحمد عبد العال \\ أستاذ القانون العام المساعد إعدا \\ كلية الحقوق - جامعة جنوب الوادي
}

\section{موجز عن البحث}

لقد أدى تغيير دور الدولة من دولة حارسة إلى دولة متدخلة في كافة الميادين، إلى جعل الوظيفة العامة الشريان الحيوي لتحقيق أهداف المجتمع؛ والنهوض بمستو اه في كافة المجالات الاقتصادية والسياسية والاجتماعية؛ فبعد أن كانت ملكَّ لشاغلها تباع وتشترى بالمال أو تمارس كسلطة عامة، وامتيازاً في مواجهة الشعب، أصبحت خدمة عامة، وتكليف يضم طائفة من الاختصاصات والمسئوليات يمارسها شاغلها للصالح العام ولما كان الأمر كذلك، كان لزاما على الدولة أن تتبع سياسة تحفيزية من خلالها تحقق رضاء الموظف العام عن وظيفته ليؤديها بكفاءة عالية تلبي حاجات المتعاملين مع المرفق العام، وتحقق المصلحة العامة، خاصة في ظل الظروف الاقتصادية الحالية التي جعلت الموظف بنظر إلى الوظيفة على أنها الأمان من الفقر والنجاة من تقلبات 
الزمن، وهذا ما يفسر لنا التكالب أو التسابق على الالتحاق بالوظيفة العامة .

ومن هنا كان اختياري لموضوع بحثي (الأجور الحافزة ودورها في تحقيق الرضا

الوظيفي لدى الموظف العام في النظامين الإداري الوضعي الإسلامي). وقد قسمت هذا

البحث إلى مبحثين وخاتمة يسبقهما تمهيد ومقدمة، وذلك على النحو التالي:

المقدمة: في أهمية الموضوع وأسباب ومنهج وخطة دراسته .

التمهيد: في التعريف بالموظف.

المبحث الأول: الإطار العام للرضا الوظيفي. وفيه عدة مطالب المطلب الأول:

مفهوم الرضا الوظيفي وأهميته. المطلب الثاني: أنواع الرضا الوظيفي وخصائصه. المطلب الثالث: العوامل المؤثرة في الرضا الوظيفي. المطلب الرابع: أساليب قياس ولميس الرضا الوظيفي ومظاهر تحققه .

المبحث الثاني: النظام القانوني للأجور الحافزة •وفيه عدة مطالب. المطلب الأول: مفهوم الأجور الحافزة وأهميتها. المطلب الثاني: مشتملات الأجور الحافزة. المطلب الثالث: أسس وطرق تقدير الأجور الحافزة.

ونظراً لأن طبيعة دراستنا هذه مقارنة، سوف نقوم بمقارنة الموضوعات السابقة

بالشريعة الإسلامية كلما تيسر لنا ذلك.

أما عن الخاتمة فستكون إن شاء الله في أهم النتائج المستخلصة من الدراسة وأهم

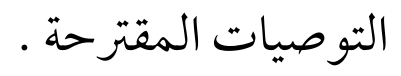

الكلمات المفتاحية : الموظف العام، الرضا الوظيفي، أهمية الرضا ووسائل قياسه، علاقة الرضا الوظيفي بالأجور الحافزة، أثر الأجور الحافزة على الرضا الوظيفي، مشتملات الأجور الحافزة، التطبيقات العملية للأجر الحافزة. 


\title{
The Role of Incentive Wages in Achieving Job Satisfaction
}

\section{General Employee in The Positive and Islamic Administrative Systems}

\author{
Sabry GalabY Ahmed Abdel Aal
}

Department of Public Law- Faculty of Law

South Valley University- Egypt

\section{Abstract:}

Changing the role of the state from a guardian state to an intervening state in all fields has made the civil service the vital artery to achieve the objectives of society; The people have become a public service، entrusted with a range of competencies and responsibilities exercised by the public concern.

As such, the State had to adopt a catalytic policy whereby the public servant was satisfied with his job in order to perform it efficiently to meet the needs of the clients of the public facility and to achieve the public interest. especially in the current economic circumstances that made the employee view the job as safety. From poverty and escape from the vicissitudes of time.

Hence my choice of research topic (incentive wages and their role in achieving job satisfaction of the public employee in the Islamic positive administrative systems). This research has been divided into two papers and a conclusion preceded by a preamble and an introduction، as follows:

Introduction: In the importance of the subject and the reasons and methodology and plan of study

Preface: In the definition of employee

The first topic: the general framework of job satisfaction. There are several demands of the first requirement: the concept of job satisfaction and its importance. The second requirement: types of job satisfaction and characteristics. The third requirement: factors affecting job satisfaction. Fourth requirement: methods of measuring job satisfaction and manifestations achieved.

The second topic: the legal system of incentive wages. The first requirement: the concept of incentive wages and their importance. Second requirement: the incomes of incentive wages. The third requirement: the foundations and methods of estimating incentive wages.

Given that the nature of this study is comparative، we will compare the previous topics with Islamic law whenever possible

As for the conclusion will be، God willing، in the most important results of the study and the most important recommendations proposed.

Keywords: public employee، job satisfaction، the importance of satisfaction and the means of measuring it the relationship of job satisfaction with incentive wages، the impact of incentive wages on job satisfaction، incentive wage implications، practical applications of incentive pay. 


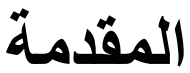

الحمد لله والصلاة والسلام على سيدنا رسول الله، وعلى آله وصحبه ومن والاه، وبعد :

فشعور الموظف العام بالرضا تجاه عمله له انعكاساته الإيجابية على أدائه لأعمال وظيفته، ولا يخفي أن قيام الموظف العام بواجبات وظيفته بكفاءة له دوره الفعال في رفاهية المجتمع وتحقيق استقرار •

ومن هنا كان اهتمام الأنظمة بالموظف العام من كل الجوانب خاصة تحقيق رضاه عن عمله من أولويات اهتماماتها.

ولقد أدى تغيير دور الدولة من دولة حارسة إلى دولة متدخلة في كافة الميادين، إلى جعل الوظيفة العامة الشريان الحيوي لتحقيق أهداف المجتمع؛ والنهوض بمستو اه في كافة المجالات الاقتصادية والسياسية والاجتماعية؛ فبعد أن كانت ملكَّا لشاغلها تباع وتشترى بالمال أو تمارس كسلطة عامة، وامتيازاً في مواجهة الشعب أصبحت خدمة عامة، وتكليف يضم طائفة من الاختصاصات والمسئوليات يمارسها شاغلها للصالح

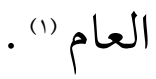
ولما كان الأمر كذلك، كان لزاما على الدولة أن تتبع سياسة تحفيزية من خلالها

(1) ير اجع في ذلك : د. على عبد القادر مصطفي : الوظيفة العامة في النظام الإسلامي وفي النظم الحديثة : ط/ 1 ه ، rه19 ام ، ط / مطبعة السعادة ص كه ـ د. محمد أنس قاسم جعفر : مبادئ الوظيفة العامة وتطبيقاتها على التشريع الجزائري ، ط/ اخوان مورافتلي به19 ام ص 7 ـ د. ماجد راغب الحلو : القانون الإداري ، ط/ دار

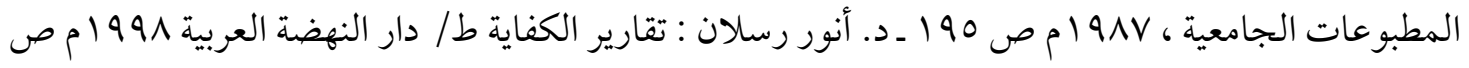


تحقق رضاء الموظف العام عن وظيفته ليؤديها بكفاءة عالية تلبي حاجات المتعاملين مع المرفق العام، وتحقق المصلحة العامة . ولو أردنا الوقوف على العوامل المحددة للرضاء الوظيفي نجدها كثيرة ومتعددة واختلفت حولها آراء الباحثين (1) . ومن وجهة نظري كان هذا الاختلاف نابعَ إلى حد كبير من نظرة الموظف العام إلى الوظيفة، حيث كان البعض ينظر إليها باعتبارها سلطة عامة يشبع من خلالها رغباته التسلطية، ويحقق ذاته ويشبع دوافع الوجاهة والعظمة في داخله من خلالها . أما البعض الآخر كان يعتبرها مصدر رزقه الذي يعينه ومن يعول على اشباع حاجاته.

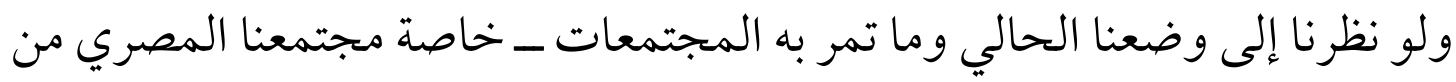
تقلبات اقتصادية، تجعل السو اد الأعظم من الموظفين وغيرهم، إن لم يكن الجميع ينظر إليها باعتبارها الأمان من الفقر والنجاة من تقلبات الزمن، وهذا ما يفسر لنا

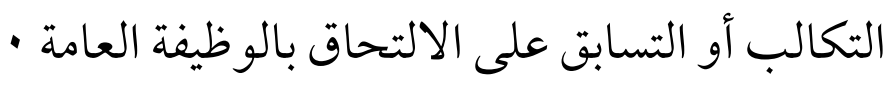
ومن هنا كان اختياري لموضوع بحثي (الأجور الحافزة ودورها في تحقيق الرضا

(1) اختلفت وجهات نظر الباحثين في عناصر دراسة الرضا الوظيفي حسب دراساتهم التجريبية ، فالبعض ذكر

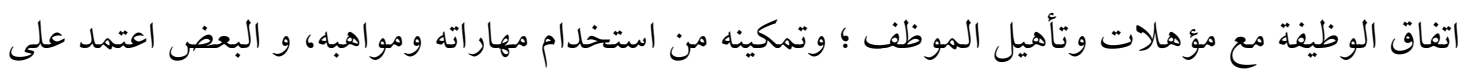

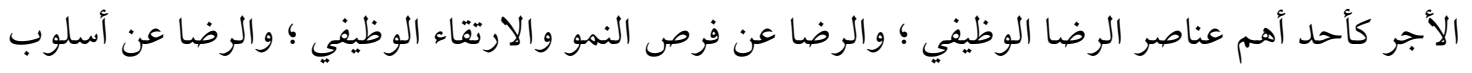

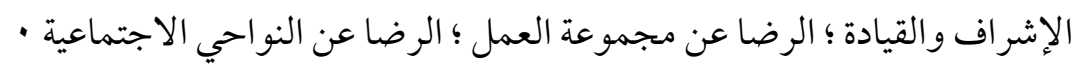

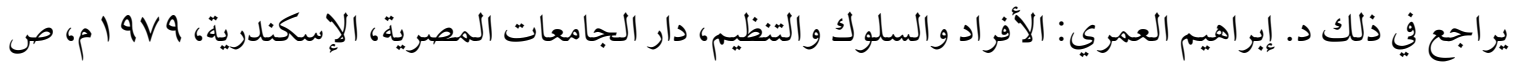
• • _ د. أحمد فاضل عباس مكي: التطور التنظيمي في الجهاز المركزي للتظيم والإداري، برامج القادة

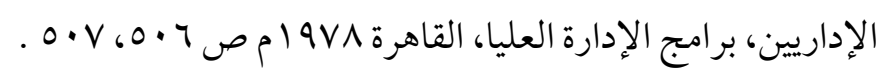


الوظيفي لدى الموظف العام في النظامين الإداري الوضعي الإسلامي).

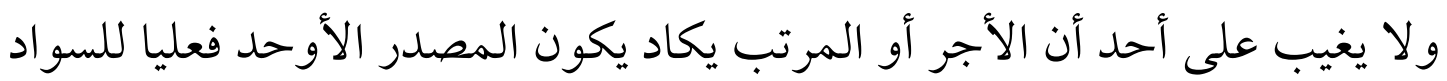
الأعظم من الموظفين العموميين، لذا كان اهتمامنا بهذا المصدر لتحقيق الرضا الوظيفي

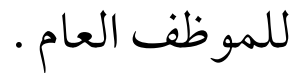

\section{و وإذا كان الأجر أو المرتب مقابل العمل، ففيما تتمثل صفة التحفيز فيه؟} وسنجيب عن هذا التساؤل عند الحديث عن الأجور الحافزة، وهي التي تسد حاجة الموظف العام ومن يعول وتوفر لهم حياة كريمة، وما تفعله هذه الأجور في بث الرضا والطمأنينة في نفوس الموظفين، الأمر الذي يجعلهم متفانين في أداء أعمالهم وخدمة تهرة

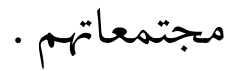
وإذا نظرنا إلى الشريعة الإسلامية نجدها قد اعتنت بفئة الموظفين العموميين عناية منقطعة النظير، بداية من اختيارهم على أسس ثابتة، ومعاير واضحة تجلت في قوله

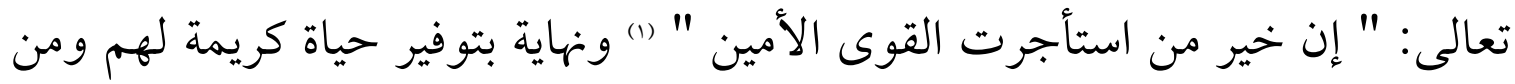
يعولوا، الأصل فيها قوله صلى الله عليه وسلم: من ولى لنا شيئًا فلم يكن له أمرأة فليتزوج، ومن لم يكن له مسكن فليتخذ مسكنًا، ومن لم يكن له مركب فليتخذ مركبًا، ومن لم يكن له خادم فليتخذ خادمـا ومن أعد سوى ذلك جاء يوم القيامة غالاً سارقا" ((). فالشريعة الإسلامية فطنت إلى أن رضاء الموظف العام عن عمله النابع من استقرار

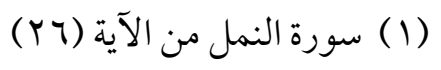

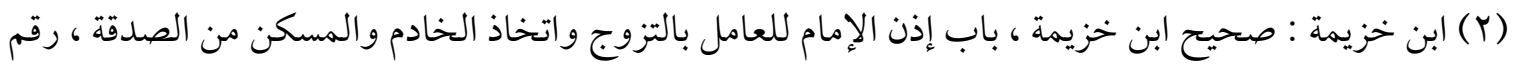

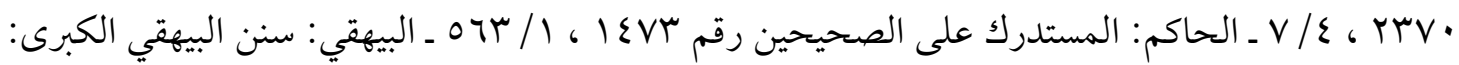

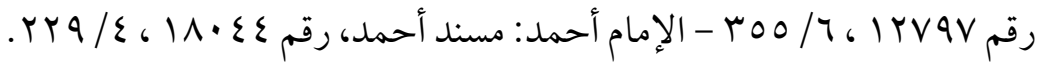


حياته الاقتصادية من أكبر وأعظم الدوافع لتفانيه وإخلاصه في القيام بأعباء وظيفته والتفرغ لقضاء حوائج الناس، وهذا ما يفسر لنا قول عمر بن عبد العزيز ـ رضى اله عنه ـ " ما طاوعني الناس على ما أردت من الحق حتى بسطت لهم من الدنيا شيئً " (1). والشريعة الإسلامية إذ قررت ذلك كان لها السبق في تحقيق رضا الموظف العام عن وظيفته لكونها تقيه ومن يعول تقلبات الزمن في حياته وبعد مماته.

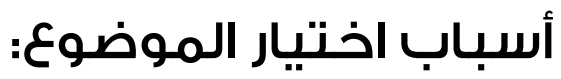
والذي دعاني للكتابة في هذا الموضوضو طائفة من الأسباب، منها: 1 - أهمية المرتب للموظف العام: يمثل المرتب المصدر الأوحد لكثير من الموظفين

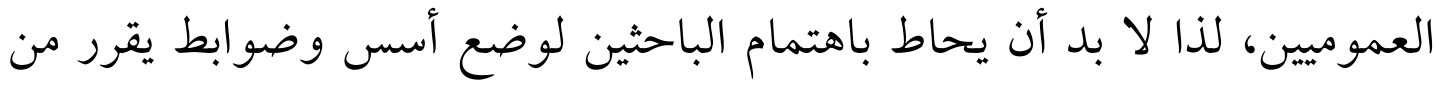
خلالها تضمن كفايته لسد حاجات الموظف ومن يعول وتقييهم تقلبات الزمن. r- الواقع الذي نعيشه أثبت عدم كفاية المرتبات لسد حاجات الكثير من الموظفين، خاصة في الآونة الاخيرة في مصر بعد تعويم الجنيه المصري والارتفاع الجنوني للأسعار، مع ثبات المرتبات، لذا كان من الواجب عليّ كباحث في القانون العام والوظيفة العامة أن أتعرض لهذا الموضوع لعلي أساهم في وضع نظرية أو فكرة تفيد في التقدير الصحيح لمرتبات الموظفين والقدر الكافي لهم، مع مراعات إمكانياتهم ومؤهلاتهم وطبيعة أعمالهم. r- أهمية الرضا عن الوظيفة التي يشغلها الموظف العام، حيث إن الموظف الراضي عن عمله يؤدي هذا العمل براعة وإخلاص، مما يزيد من الانتاجية والجودة في 
تقديم الخدمات العامة التي تقدمها الوظيفة العامة.

ع - عدم وجود أسس تقدير موضوعية يمكن الاستناد عليها عند التقدير، مما يترتب

على ذلك عدم العدالة في تقدير المرتبات، ولا يخفى أن ذلك له تأثير سلبي على

الرضا الوظيفي، الذي ينتج عنه في الغالب أداء سيء لو اجبات الوظيفة العامة.

منهج الدراسـة : منهـئ

المنهج المتبع في هذه الدراسة هو المنهج المقارن القائم على الاستقراء والتحليل، والتأصيل، ثم الموازنة لإبراز الفوارق الجوهرية في النظرة الكلية، وذلك دون تطويع لأحكام الشريعة لتتناسب مع الشرائع الوضعية؛ لأن الشريعة الإسلامية لا تعلو مكانة أو تهبط منزلة بنسبتها إلى نظام وضعي أو نسبة نظام وضعي إليها، باعتبارها شريعة السماء الأخيرة و الخالدة، مستمدة أحكامها من صاحب الكمال المطلق الله رب العالمين . خطـة الدراسـة : خيرة

وقد قسمت هذا البحث إلى مبحثين وخاتمة يسبقهما تمهيد ومقدمة، وذلك على

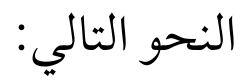

المقدمة: في أهمية الموضوع وأسباب ومنهج وخطة دراسته التمهيد: في التعريف بالموظف. المبحث الأول: الإطار العام للرضا الوظيفي.

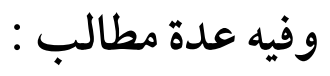
المطلب الأول: مفهوم الرضا الوظيفي وأهميته. المطلب الثاني: أنواع الرضا الوظيفي وخصائصه. المطلب الثالث: العوامل المؤثرة في الرضا الوظيفي 


$$
\begin{aligned}
& \text { المطلب الرابع: أساليب قياس الرضا الوظيفي ومظاهر تحققه . } \\
& \text { المبحث الثاني: النظام القانوني للأجور الحافزة . }
\end{aligned}
$$

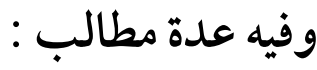

$$
\begin{aligned}
& \text { المطلب الأول: مفهوم الأجور الحافزة وأهميتها. } \\
& \text { المطلب الثاني: مشتملات الأجور الحافزة. } \\
& \text { المطلب الثالث: أسس وطرق تقدير الأجور الحافزة. }
\end{aligned}
$$

ونظراً لأن طبيعة دراستنا هذه مقارنة، سوف نقوم بمقارنة الموضوعات السابقة

$$
\text { بالشريعة الإسلامية كلما تيسر لنا ذلك. }
$$

أما عن الخاتمة فستكون إن شاء الله في أهم النتائج المستخلصة من الدراسة وأهم

$$
\text { التوصيات المقترحة . }
$$

وأسأل الله العون والتوفيق فإنه نعم المولى ونعم النصير

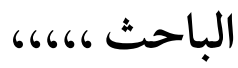




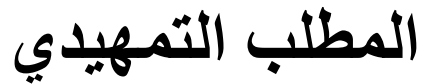 التصريف بالموظة المُ العام}

يعتبر الموظف العام الممثل الحقيقي للدولة والمعبر القانوني عن إرادتها ، فالدولة لا

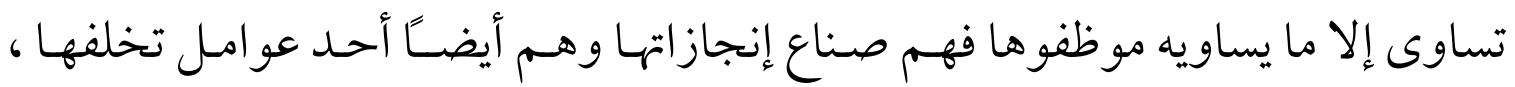
ذلك أن الدولة لا تعلو امكانًا إلا بقـدر كفـايتهم في تحقيـق أهـدافها ، ولا تهبط منزلـة إلا بمقدار ما يصيبهـم من الوهن في تنفيذ سياستها. فالموظف العـام يعتبر أحـد أهـم الركائز التي يقوم عليها أي جهاز إداري في أي نظام وضعي أو إسلامي. ويعد الموظف العام - الكفء - الأساس الذي يقوم عليه البناء الوظيفي في أية دولة ، لذلك قيل بأن قوة الدولة تقاس بمستوى موظفيها فكراً وسلوكَّا"). لـذلك كان لتحديـد مفهوم الموظف العام أهمية كبيرة. ولقد أثنار تحديد مفهوم الموظف العام جدلاً كبيراً بين فقهاء القانون بعد أن كف المشرع - في معظم التشريعات - يده عن وضع تعريف جامع مانع للموظف العام ، واكتفي بوضع الضوابط والشروط التي يتم على أساسها الاختيار للوظيفة العامة ، وتحديد العلاقة التي تربطه بالدولة على أنها علاقة تنظيمية أو لائحية تحكمها القوانين واللوائح ونظراً لخلو معظم التشريعات والأنظمة المقارنة - ومنهـا التشـيع المصـري(")-مـن

(1 ) د. عمر حلمي فهمي: مبدأ الجدارة في تولية الوظائف العامة، مطبعة جامعة عين شمس،ع 99 (م، ص ه . (Y) وذلك على الرغم من وجود عدة نصوص في قوانين التوظف المختلفة بداية من القانون رقم • ا لسنة 1901 19 ، و انتهاء بالقانون رقم 11 لسنة7 1 • ب م، تعرضت لبيان صفة الموظف العام ، إلا أن هذه النصوص في صياغتها المختلفة لم تتضمن تعريفًا لفكرة الموظف العام بمعناه الفقهي المقصود في مجال القانون الإداري ، 
وضع تعريف جامع مانع للموظف العام، اجتهد كل من الفقه والقضاء في تحديد مفهوم

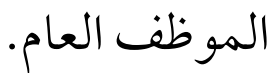
وحســـا فعلـت هـذه التشـريعات إذ تحكــم في الواقـع هـذه التعريفـات مجموعـة مـن المؤثرات والمعطيات التي تختلف، ليس فقط من دولة إلى أخرى، بل وأيضـًا من وقت

بل قصد منها تحديد الخاضعين لأحكام هذه القوانين ، ولم تشترط إلا تعيين المواطن من قبل السلطة المختصة في إحدى الوظائف التي حددها المشرع ، ومن أمثلة هذه النصوص ، نص المادة الأولى من هذا

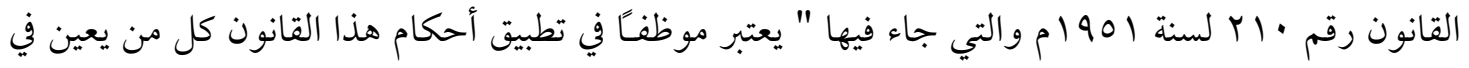

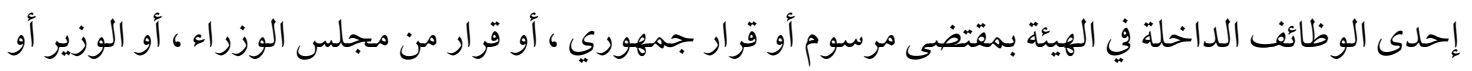

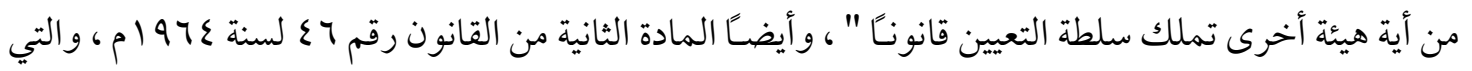
تقول " يعتبر عاملاً في تطبيق أحكام هذا القانون كل من يعين في إحدى الوظائف الدائمة أو المؤقتة بقرار من

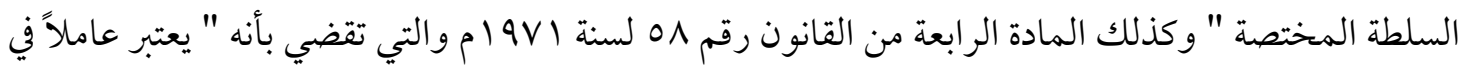
تطبيق أحكام هذا القانون كل من يعين في إحدى الوظائف المبينة بموازنة كل وحدة ، ويكون التعيين في الوظائف المؤقتة بالنسبة للمتمتعين بالجنسية المصرية أو الأجانب وفقًّ للقواعد التي تتضمنها اللائحة التنفيذية مع مراعاة الأحكام الخاصة بتوظيف الأجانب " ، و أخيراً نص الفقرة الأخيرة من المادة الأولى من

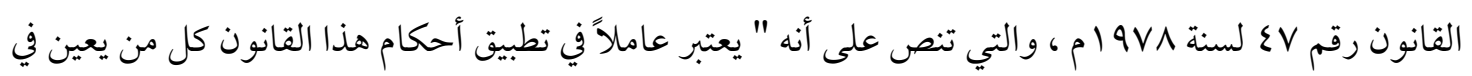
إحدى الوظائف المبينة بموازنة كل وحدة " .

يراجع في ذلك: د. سليمان محمد الطماوي : مبادئ القانون الإداري دراسة مقارنة ، الكتاب الثاني ، ط / دار

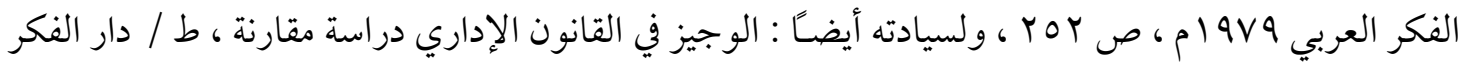
العربي ، القاهرة ب991 ام ص ه • ع - د. ماجد راغب الحلو : القانون الإداري ، ط / دار المطبوعات الجامعية

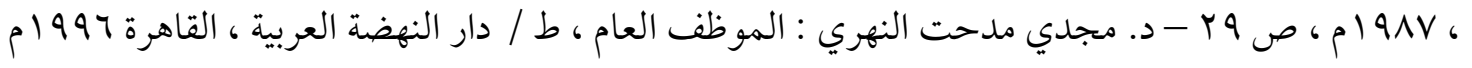
ص 7 ، V - د. رمضان محمد بطيخ : الوسيط في القانون الإداري ط / دار النهضة العربية ، القاهرة 997 ام ،

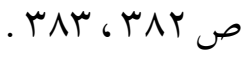




$$
\text { إلى آخر في الدولة الواحدة'(1). }
$$

وبسبب خلو التشريع المصري من وضع تعريف دقيق للموظف العـام اجتهـ الفقهـ و القضاء الإداريين في وضع تعريف للموظف العام، ورغم تعدد أحكام القضـاء وأقوال الفقهاء(r) في وضع تعريف دقيت للموظف العـام ، إلا أن هـذه التعريفـات مهمـا اختلفـت

(1) د. سليمان الطماوي : مبادئ القانون الإداري ، صبr ror - د. علي عبد القادر مصطفي : الوظيفة العامة في

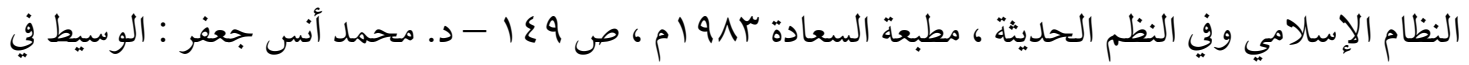
القانون العام، أسس وأصول القانون الإداري، ط/ إخوان مور افتلي، ص ه •r ، • اس - د/ مجدي النهري: الموظف العام، ص 7- د. رمضان بطيخ: الوسيط في القانون الإداري، ص rی r . (r) ومن أحكام القضاء الإداري المصري في بيان المقصود بالموظف العام ، نذكر منها ما يلي : ق ما أقرته المحكمة الإدارية العليا في حكمها الصادر في 9 / / /979 ام في الطعن رقم ب19 لسنة 9 قضائية من أن " المعوقات الأساسية التي عليها فكرة الموظف تخلص في أن يكون تعيين الموظف بأداة قانونية لأداء عمل دائم في خدمة مرفق عام تديره الدولة ، أو أحد أشخاص القانون العام " . راجع : مجموعة المكتب الفني لمجلس الدولة ، السنة الرابعة عشر ، من 10 / إلى آخر ديسمبر 979 ام ،

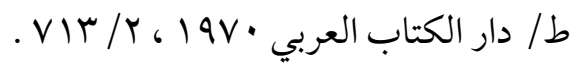
- كما ذكرت المحكمة الإدارية في حكم آخر لها تقول فيه "وغني عن البيان أن ليس كل من تمنحه الدولة مرتبً يعتبر موظفًا عامـًا، فإن صفة الموظف العام لا تقوم بالشخص ، ولا تجري عليه بالتالي أحكام الوظيفة العامة ، إلا إذا كان معينًا في عمل دائم في خدمة مرفق عام تديره الدولة أو السلطات الإدارية بالطريق المباشر " راجع

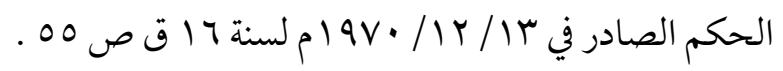
* ومن الأحكام التفصيلية في هذا الشأن حكم المحكمة الإدارية العليا الصادر في /0/ / ب7 19 في الطعن رقم r 17 السنة V ق و الذي أقرت فيه أنه " ليس للتشريعات ، أو اللو ائح في مصر نص يعرف الموظف العمومي ، ولا يمكن اعتبار نص المادة الأولى من قانون نظام موظفي الدولة رقم • اب لسنة أل أم تعريفًا للوظيفة العامة ، أو تعريفًا للموظف العمو مي ، إذ أنه اقتصر فقط على بيان أولئك الذين تطبق عليهم أحكام هذا القانون ، ولئن كانت أحكام هذا القانون تسري على الغالبية الكبرى من موظفي الدولة ومستخدميها ، إلا أنها مع ذلك لك 
لا تسري على فئات أخرى من طوائف الموظفين الذين تنظم قواعد توظيفهم قوانين خاصة ، وهناك بعض

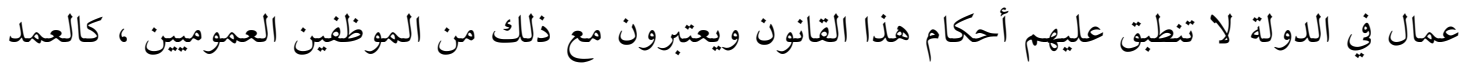
و المشايخ ، والمأذونين ، وقد تلاقى في القضاء والفقه الإداريان على عناصر أساسية للوظيفة العامة ، ولاعتبار

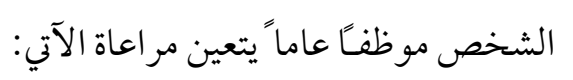

أ) أن يساهم في العمل في مرفق عام تديره الدولة عن طريق الاستغلال المباشر ، وفي مصر يعتبرون موظفون

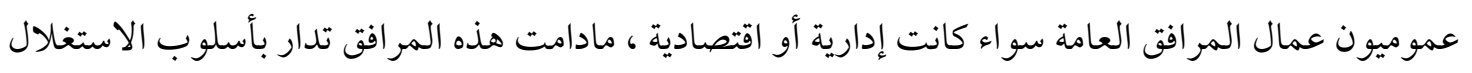
المباشر ب) أن تكون المساهمة في إدارة المر افق العامة عن طريق التعيين أساسكا وقرار إسناد الوظيفة يكون عن طريق عمل فردي ، أو مجموعي يصدر من جانب السلطة العامة ، ويجب أن تقابله موافقة من جانب صاحب الشأن ، فالموظف العمومي يساهم في إدارة المرافق العامة مساهمة إرادية يقبلها دون قسر أو إرغام ، أما الالتحاق الجبري في خدمة مرفق عام فلا تطبق عليه أحكام الوظيفة العامة.

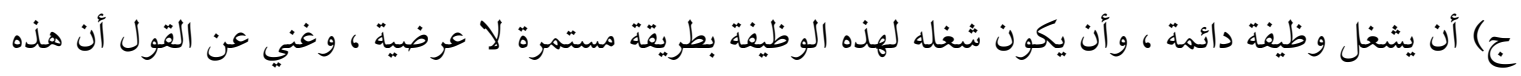
العناصر لا يمكن اعتبارها عناصر قاطعة نهائية للحكم على عامل من عمال الإدارة بأنه موظف إلا أنها عناصر

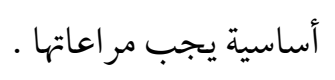

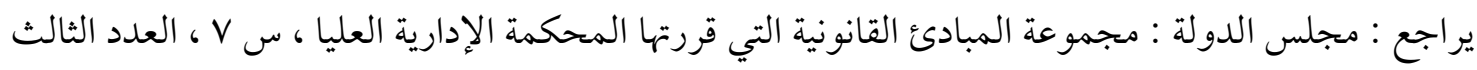

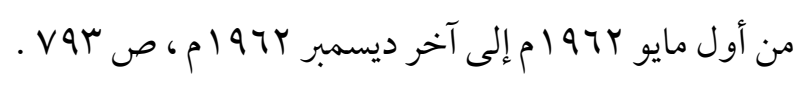

أما عن أقوال الفقهاء ، فقد ذكر الفقهاء تعريفات كثيرة للموظف العام في فقه القانون الإداري ، نذكر منها على سبيل المثال: - n

* تعريف الدكتور / سليمان الطماوي للموظف العام بأنه " الشخص الذي يعهد إليه بعمل دائم في خدمة مرفق عام

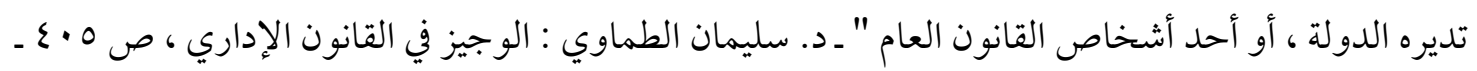

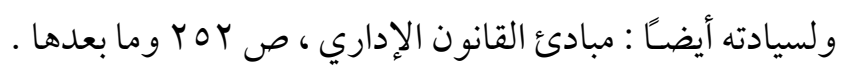
* عرف أيضًا الدكتور / ماجد الحلو الموظف العام بأنه " كل من يتولى وظيفة دائمة أو مؤقتة في خدمة مرفق عام

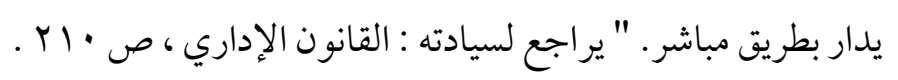

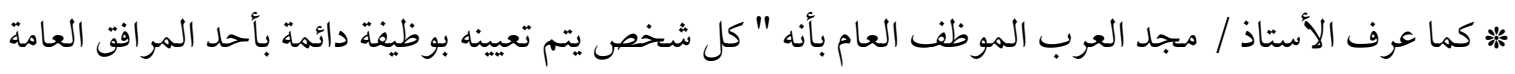

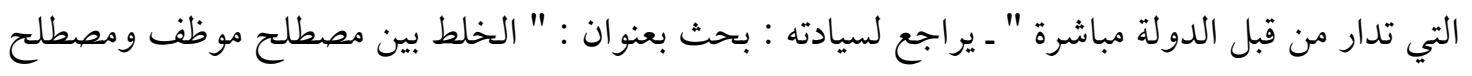


ألفاظها ، فقد جمعت في النهاية عناصر أساسية اتفق كل من الفقه والقضاء على ضرورة تو افرها للتعرف على الموظف العام ، وما تضيفه بعض الآراء إلى التعريف زيـادة على هذه العناصر هو من قبيل التزيد في الوصف بما لا يعد من مقومات التعريف التي تفيده ، أو توسع فيه دون أن تمس جوهر هذه العناصر . ومن التعريفات التي جمعت العناصر الأساسية ، والتي تمثل القـدر المتفق عليه بين الفقـه و القضـاء الإداريـين في مصـر، التعريـــ الـذي سـاقه الـدكتور/ علـي عبــ القـادر مصطفي ، حيث عرف سيادته الموظف العام بأنه : " كل شخص يصـدر قرار بتعيينه في وظيفة دائمة تديرها الدولة بطريقة مباشرة برضاه " (1) . فقد اشتمل هذا التعريف على عدة عناصر جوهرية تعـد شـروطَّا يجـب تو افرهـا لكل يطلق على الشخص صفة الموظف العام: أولاً: صدور قرار بتعيينه في الوظيفة العامة من السلطة المختصة: لكي يكتسب الشخص صفة الموظف العـام لابـد أن يصـدر قرار بتعيينه مـن السـلطة عامل خطأ " منشور على الإنترنت ، شبكة القانون ، موقع مجالسنا ، ص 1 ـ .

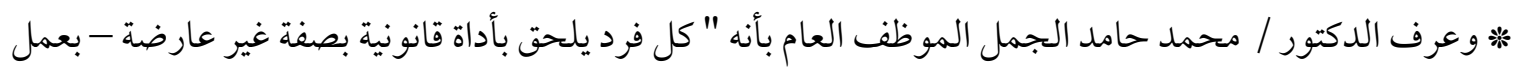
دائم - في خدمة مرفق عام يديره شخص من أشخاص القانون العام بالطريق المباشر " . راجع لسيادته :

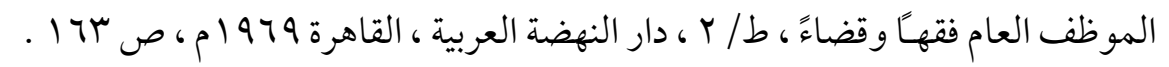
وللمزيد من التعريفات المختلفة للموظف العام يراجع على سبيل المثال : د. محمد أنس جعفر : الوسيط في القانون العام ، ص • الب - د. مجدي النهري : الموظف العام ، ص ^ - د. رمضان بطيخ : الوسيط في القانون

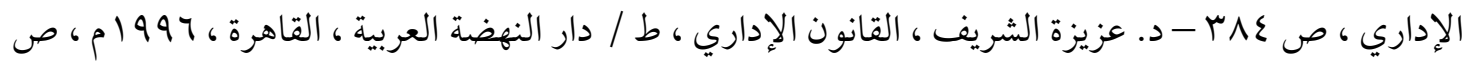

(1) د. علي عبد القادر مصطفي : الوظيفة العامة في النظام الإسلامي وفي النظم الحديثة ، ص ع 10 . 
المختصة قانونًا بالتعيين في الوظائف العامة ، وعلى ذلك فبإن مجرد ترشيح الشخص

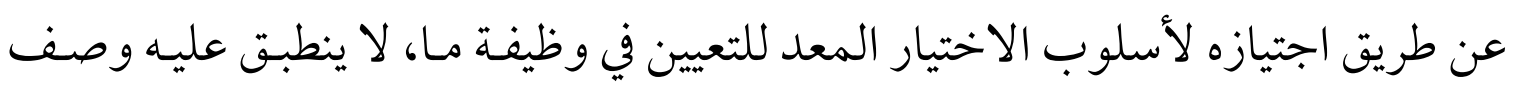
الموظف حتى ولو تو افرت فيه الشروط المقررة. ثانيًا: أن يكون العمل الذي يقوم به الموظف دائمسًا: حتي يكتسب الشخص صفة الموظف ، ومـن ثم تطبق عليه أحكام الوظيفة العامـة قانونًا لابد أن يكون العمل الذى يقوم به دائمسا وبصفة مستمرة ولا يؤثر في ذلك كون

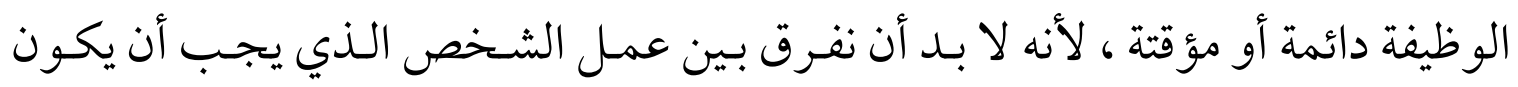
دائمسا ، وبين الوظيفة ذاتها ، فقد تكون دائمة أو عرضية يمكن إلغاؤهـا ، وفي هذه الحالة ينتقل الشخص إلى وظيفة أخري حتي يكون عمله دائمكا').

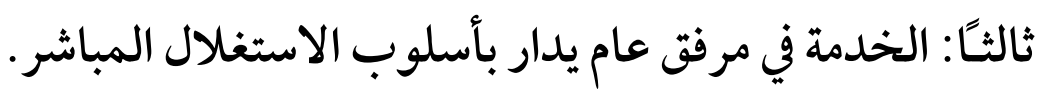
المرافق العامة هي المشروعات التي تفي بحاجات جماعية ذات نفع عام"(r). ويشترط

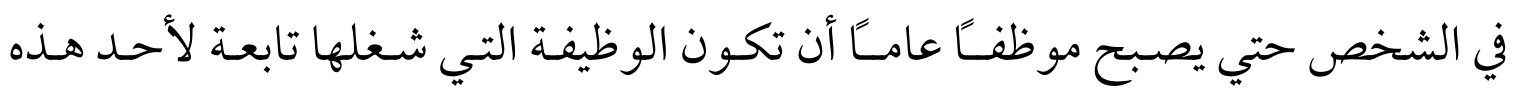
المر افق ، التي تدار بالأسلوب المباشر م(ت). أيا كان نوعها (مر افق إدارية ـ أو اقتصادية أو

$$
\begin{aligned}
& \text { (1) (د. على عبد القادر مصطفي : الوظيفة العامة ، ص } 109 .
\end{aligned}
$$

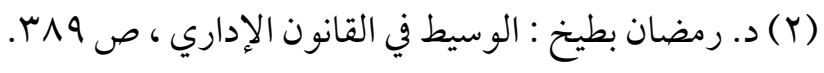

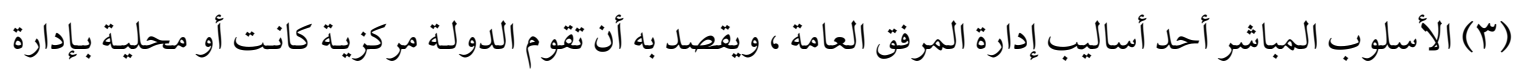
المرفق العام مباشرة بأمو الها وعمالها وتحت مسئوليتها ، مستخدمة في ذلك وسائل امتيازات القانون العام ، وهـذا الأسلوب تـدار بـه المر افق الإداريـة نظراً لخطور رتها ، أو لإحجـام الأفراد عن القيام بها لقلة أو انعـدام

أرباحها.

يراجـع في ذلك : د. سـليمان الطماوي : مبادئ القانون الإداري ، ص •7 ـ ولسيادته أيضسَّ : الوجيز في القـانون

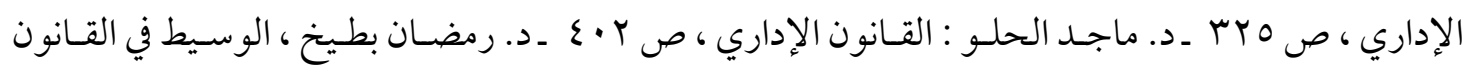


تجارية )، ويغض النظر عـن الجهـة التي تتـولى إدارة هـذه المرافق ، مركزيـة كانـت ، أو إقليمية ، ما دامت من أشخاص القانون العام". رابعًا: أن يكون التحاق الموظف بالوظيفة عن طريت الرضا. وبجانب الشروط التي سبق ذكرها ، يلزم أن تكـون الطريقـة التي دخل بها الموظف العام في الوظيفة قائمة أساسـا على الرغبة في العمل ، لأن الموظف العـام يـتبط بعمله ، بصـفة مستمرة ، ولـيس مـن المعقـول أن تطلـب الإدارة مـن الموظفـ القيـام بأعمـال الوظيفـة دون أن يرغـب في أدائهـا ، و إذا أرغــم مـن قبـل الإدارة فـإن طريقـة أدائـهـ لهـــه الأعمال يخالطها القصور الذي قد يؤدى إلى الخروج عن أهداف الوظيفة المطلوب منه

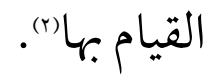
وخلاصة القول، أنه لا بــد مـن تـو افر الشـروط السـابق ذكرهـا حتي يتصفـ الشخص بصفة الموظف العام ، ومن ثم يخضع للقـانون الإداري ، ويتمتـع بمز ايـا الوظيفـة العامـة التي أختير لها. وإذا تطلعنا إلى تـاريخ الدولـة الإسـلامية نجـدها قـد بلغـت درجـة كبيـرة مـن الكفايـة السياسية والإدارية والاقتصـادية ولا غرابـة في ذلك ، فقـد كـان دستورها القـر آن الكريم الذي احتوي على علاج وتنظيم لكل مـا تحتاجـه البشـرية، وقـد اعتني فقهاء الإسـلام بدر اسة كافة الجو انب المتعلقة بالوظيفة العامـة مستخخدمين مصطلح" الولايـة أو ولايـة

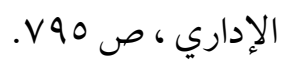

(1) د. سليمان الطماوي ، مبادئ القانو ن الإداري ، ص Y00 ـ د. محمد أنس قاسم جعفر ، الوسيط في القانون

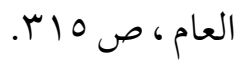

(Y) د. على عبد القادر مصطفي : الوظيفة العامة في النظام الإسلامي وفي النظم الحديثة ، ص 170 
الأمر" كمصطلح مقابل لمصطلح الوظيفة(1) العامـة ، ومصطلحات " الولاة ـ الأمـراء ـ العمال" كمصطلحات مقابلة لمصطلح الموظفين العموميين في النظم المعاصرة"). وقد عرف صاحب كتاب فتح القدير الولاية بأنها : "تنفيذ القول على الغير شـاء

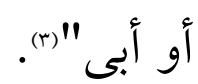

(1) الوظيفة في اللغة : ما يقدر للإنسان في كل يوم من رزق أو طعام ، وجمعها وظائف ووظف.

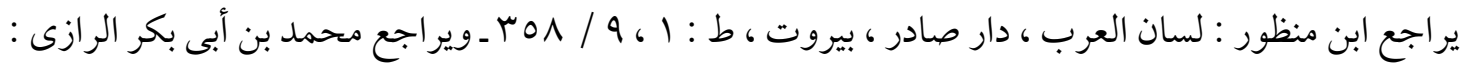

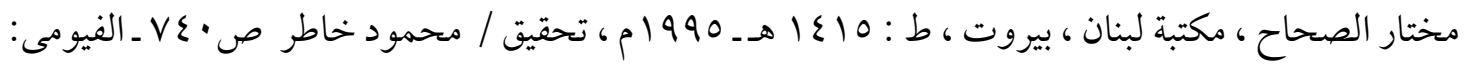

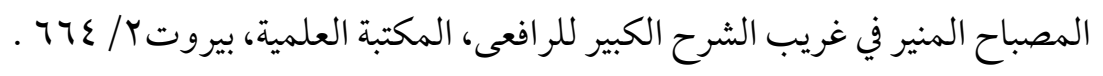
(Y) وهذا خلاصة كلام ابن تيمية في كتابه : السياسية الشرعية في إصلاح الراعي والرعية ، ط: ، و94 ا المطبعة

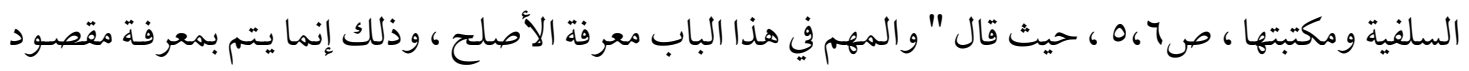
الو لاية، ومعرفة طريق المقصود فإذا عرفت المقاصد والوسائل تم الأمر" انظر ص ب أ.

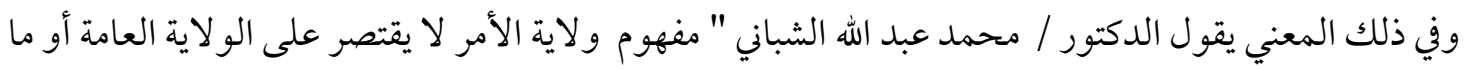

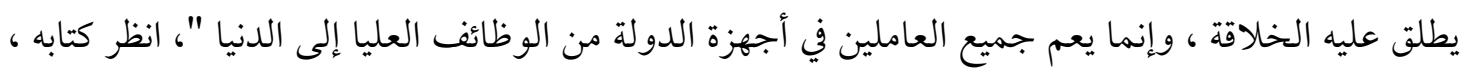

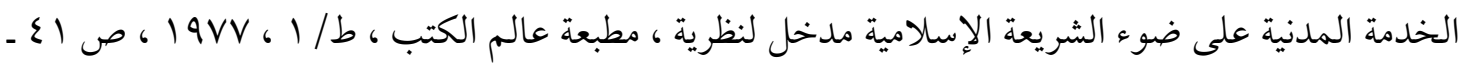
وقريب من المعني يراجع د. ظافر القاسمي : نظام الحكم في الشريعة والتاريخ الإسلامي ـ الحياة الدستورية ،

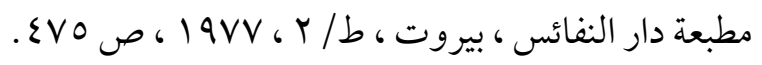
ويقول الباحث/ محمد إسماعيل مرعى " مفهوم الوظيفة العامة في العصر الحديث يقابل ولاية الأمر ، وفي الإسلام أوسع نطاقًا ، لأن الفكرة في النظام الحديث تقتصر غالبًا على الموظفين المتتشرين في الهيئات و المؤسسات العامة والإقليمية ، دون أن تشمل الوزراء أو رئيس الدولة ، أما في الإسلام فإن ولاية الأمر تشمل الجميع" - يراجع له رسالته للماجستير، وعنوانها : الحقوق الدستورية في النطاق الوظيفي بين الشريعة

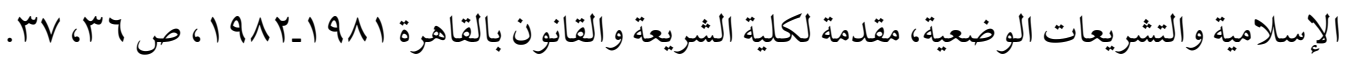
(r) كمال الدين محمد بن عبد الو احد السواسي، ثم السكندري المعروف بابن الهمام الحنفي : شرح فتح القدير

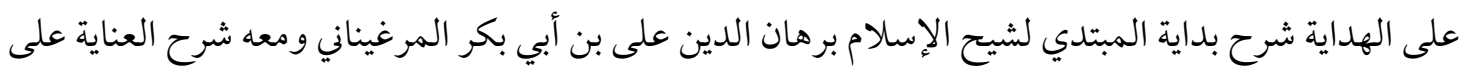


وهذا يقتضي أن يكون القول أو التصرف مرتبطَّا بالشريعة ، بـأن يكون تفويضــا مـن

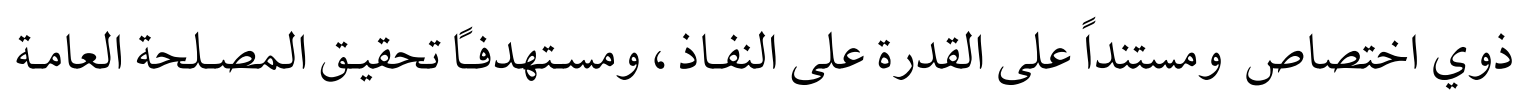

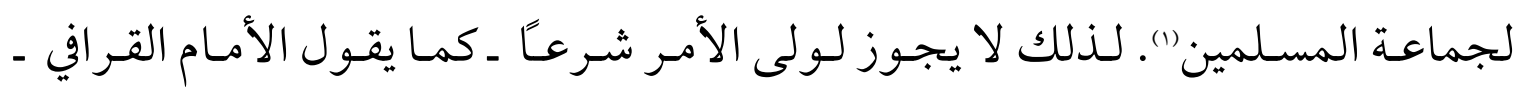

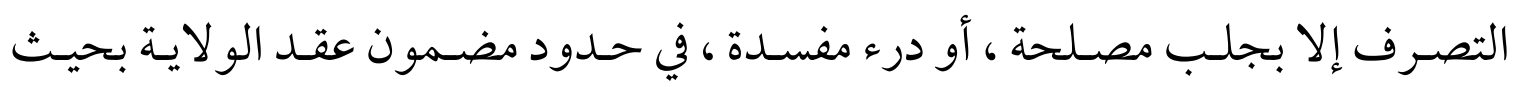

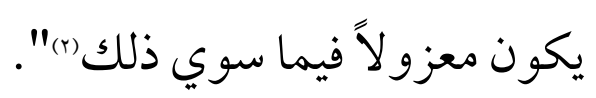

وينظر الإسلام إلى الموظف العام على أنه الحارس الأمين عليه أن ينصح للجهاز

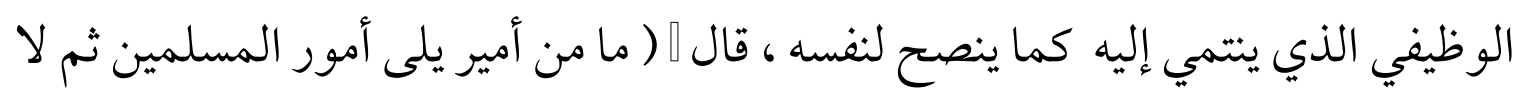
يجهد لهم وينصح إلال لم يدخل الجنة )(r).

الهداية للإمام أكمل الدين محمد بن محمود البابرتي وحاشية المحقق سعد الله بن عيسي المفتي الشهير بسعد

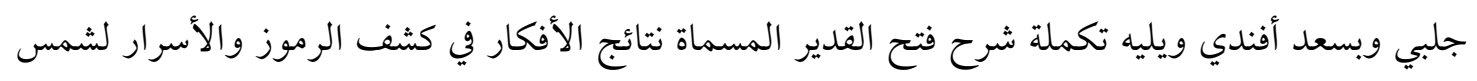

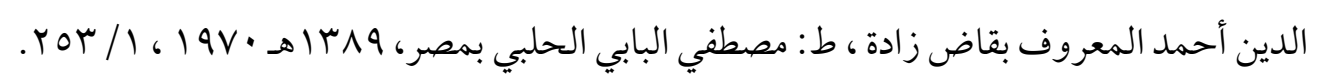
(1) د/ إبراهيم عبد الصادق محمود: الاختيار للوظيفة العامة في النظام الإسلامي دراسة مقارنة بالنظم المعاصرة ،

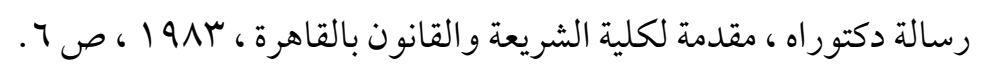

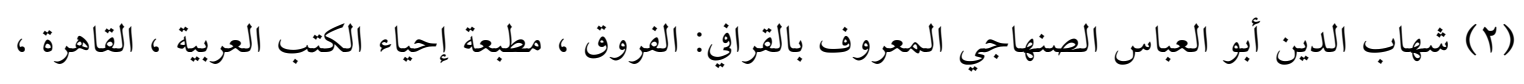

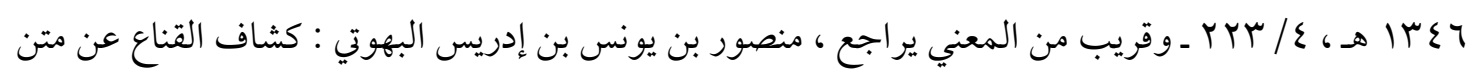

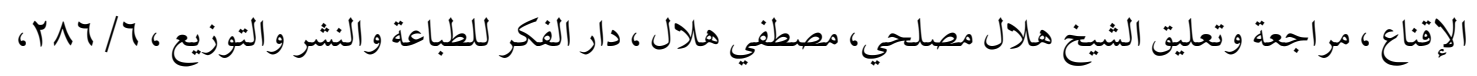

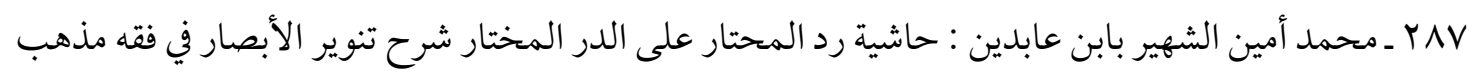

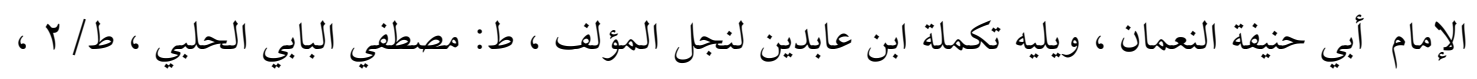

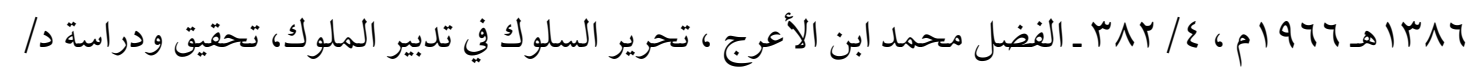

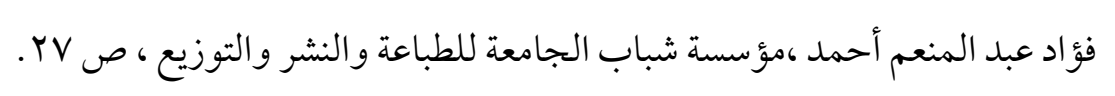

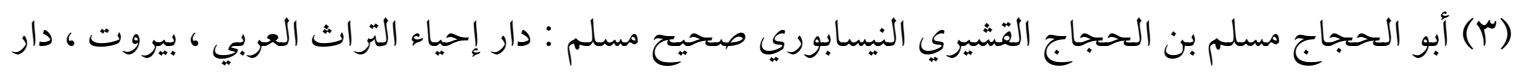

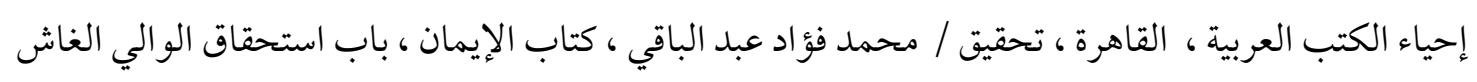

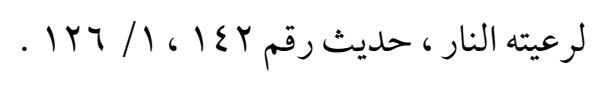


و كان الموظفون في عهد النبي ل ثلاثة أنواع ، الو لاة ، والقضـاة ، و العمال ، وكان كل

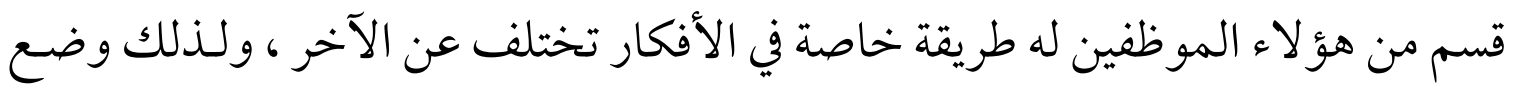
لكل فئة طريقة يتبعها من بعـده كل من يتولى مقاليد السلطة في الدولة الإسلامية)(1)،

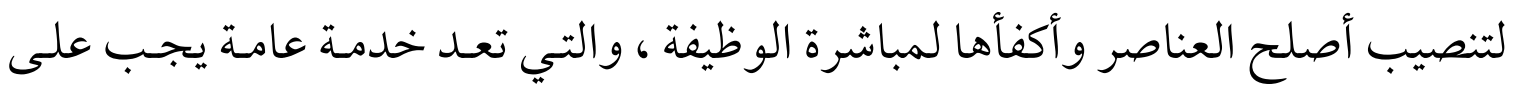

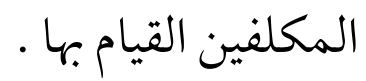

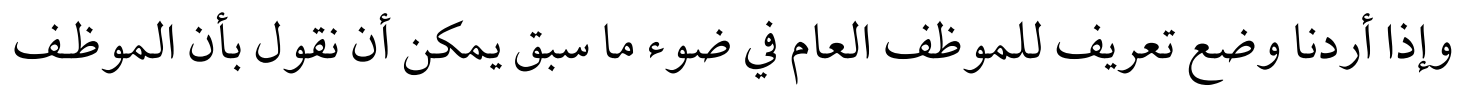

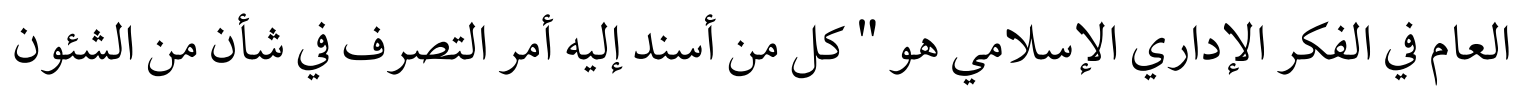

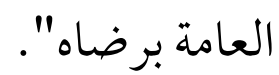
وبتحليل التعريف السابق يتضح أنه لكى يكتسب الشخص صفة الموظف العام في الفكر الإداري الإسلامي يجب أن تتو افر فيه الشروط أو العناصر الآتية :

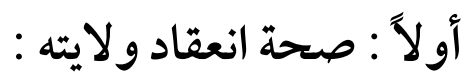

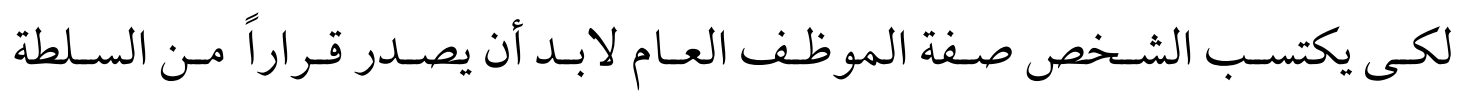

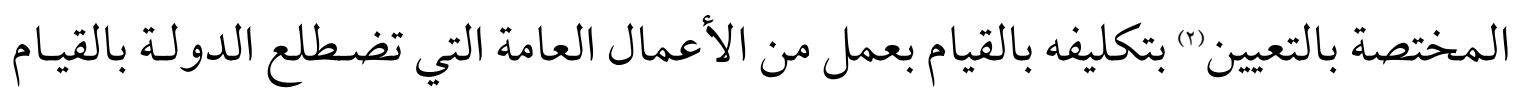
.4

(1) د. على عبد القادر مصطفي : الوظيفة العامة في النظام الإسلامي وفي النظم الحديثة ، ص س؟ ـ . (Y) ويقصد بالسلطة المختصة بالتعيين في النظام الإسلامي ، الخليفة ـ رئيس الدولة ـ باعتباره صاحب الولاية العامة والمسئول الأول ـ أمام اله والأمة الإسلامية ـ عن حفظ الدين على أصوله المستقرة ، وتدبير الشئون العامة للأمة وكذلك من يفرض إليه الرئيس إصدار قرارات التعيين ،كوزير التفويض الذي يفوض إليه رئيس

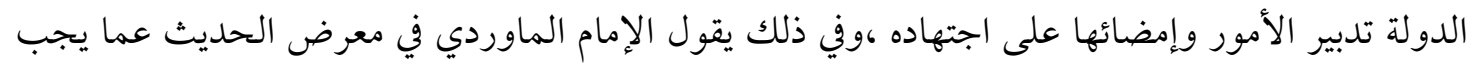
على رئيس الدولة القيام به من الشئون العامة " التاسع استكفاء الأمناء وتقليد النصحاء ، فيما يفوض إليهم من لهن

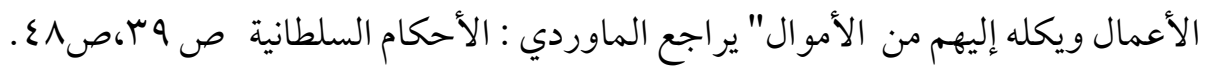


ثانيًا: تكليفه بالقيام بخدمة عامة: ولكي يكتسب أيضًا الشخص صفة الموظف العام يلزم أن يكون العمل المكلف بـهـ من قبل السلطة المختصة من الأعمال العامـة التي يجـب على الدولة القيام بها لحفظ

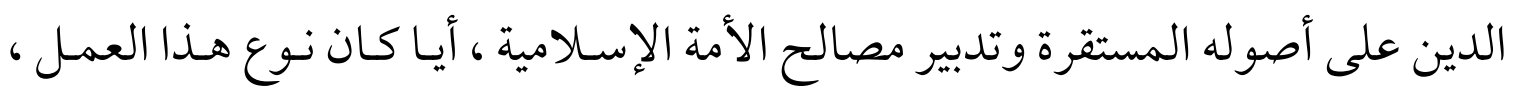

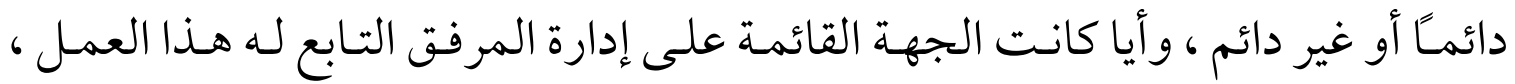
سواء كانت تـديره الدولـة مباشـرة أو عـن طريت الأشخاص ، مـادام مـن الأعمـال التي يجب على الدولة القيام بها. ثالثًا: قبول الثخص القيام بهذه الخدمة: و العنصر الثالث والأخير والواجب تو افره لاكتساب الشخص صفة الموظف العـام في الفكر الإداري الإسلامي هو رضاه أو قبوله تحمل أعباء هذه الوظيفة. وشكل القبول الصادر من الشخص يتوقف على طريقـة التوليـة ، فبإن كانت التوليـة ـ التعيين أو التقليد ـ مشافهة ، فالقبول يكون على الفور لفظًا ، ويجوز مـع التراخي ، وإن كانت التولية كتابة أو مراسلة ، جاز أن يكون القبول على التراخي". ونخلص من كل ما سبق إلى أن النظم الوضعية تتفق مع الشريعة الإسلامية في الأخــ بفكرة الموظف العام من حيث المبدأ، أما كونه يعمل في مرفق عام تديره الدولة أو أحسد أشخاصها بالطريق المباشـر ، وكـون العمل الذي يقوم بـه دائمـاً ، فهذه أمـور لـم تكـن تعرفهـا الشـريعة الإسـامية ، غيــر أنـهـ يـترك تقـديرها للسـلطة العامـة حسـبما تقتضسيه المصلحة العامة ، وبما لا يتعارض مع القواعد الكلية والأصول الشاملة التي جـاءت بها الشريعة الإسالامية. 


\section{المبحث الأول \\ الإطار العام للرضا الوظيفي وضعاً وشرعاً}

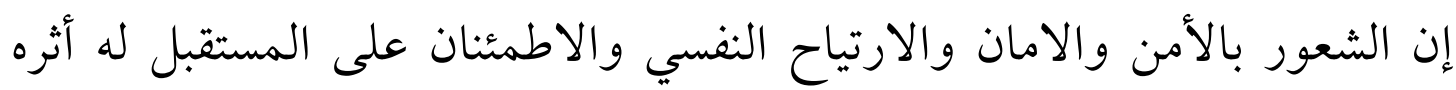

الفعال و انعكاساته الإيجابية على أداء الموظف العام لأعمال وظيفته، الأمر الذي يعود بالنفع على المرفق العام والمتعاملين معه؛ وهذا ما يفسر لنا اهتمام الباحثين بموضوع الرضا الوظيفي والعوامل المؤثرة فيه

فقد جذب موضوع الرضا الوظيفي انتباه الكثير من المفكرين والباحثين؛ حيث تسعى الإدارات المختلفة من خلاله للحفاظ على الموظفين الأكفاء ذوي الخبرة و الو لاء للمرفق الذي يعملون فيه

وفي حديثنا عن الإطار العام للرضا الوظيفي نبين مفهوم الرضا الوظيفي وأهميته في مطلب أو لا؛ ثم أنواع الرضا الوظيفي وخصائصه في مطلب ثان؛ ثم العوامل المؤثرة في الرضا الوظيفي في مطلب ثالث؛ وأخيراً طرق قياس الرضا الوظيفي ومظاهر تحققه؛ مع بيان موقف الشريعة الإسلامية من الرضا الوظيفي في كل ما سبق.

\section{المطلب الأول \\ مفهوم الرضا الوظيفي وأهميته}

بات موضوع الرضا الوظيفي من الموضوعات ذات الأهمية التي لقت الهتماملهً كبيراً من قبل الباحثين في العلوم الإدارية والموارد البشرية؛ وقد اختلفت وجهات النظر حول تحديد المقصود من الرضا الوظيفي تحديداً دقيقً؛ وفي الصفحات التالية نوضح المقصود من الرضا الوظيفي؛ ثم نبين أهميته في فرعين متتالين 


\section{الفرع الأول \\ تعريف الرضا الوظيفي}

الرضا في اللغة (1) ضد السخط وهو الشعور بالارتياح النفسي والاطمئنان ويعد مفهوم الرضا الوظيفي كما هو واضح من مفهومه العمومي، من المفاهيم السلوكية المعقدة لارتباطه بمشاعر الفرح التي يصعب تفسيرها؛ ولكون الرضا نسبى

يختلف من شخص لآخر، نظراً لاختلاف وتعدد العوامل المؤثرة في الرضا الوظيفي . وعلى الرغم من صعوبة وضع تعريف جامع مانع للرضا الوظيفي؛ إلا أن مفهومه شغل اهتمام الكثير من العلماء (()، خاصة علماء الإدارة والذي تحدد لديهم مفهوم الرضا بشكل عام؛ بأنه شعور الفرد بالراحة النفسية بعد القيام بإشباع حاجاته وتحقيق

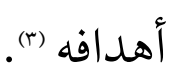

وقد شاع مصطلح الرضا الوظيفي في الأوساط الإدارية؛ خاصة في الإدارة الخاصة منذ

الثلاثينات من القرن الماضي ().

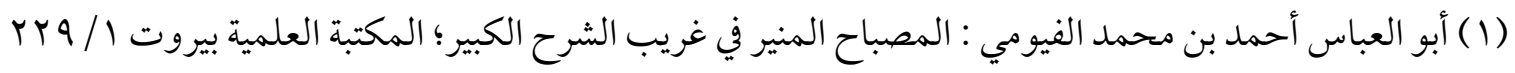

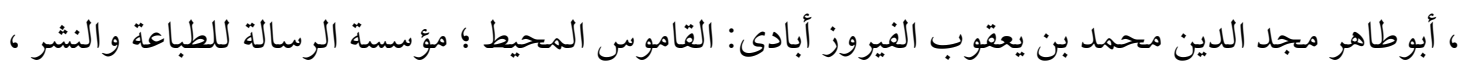

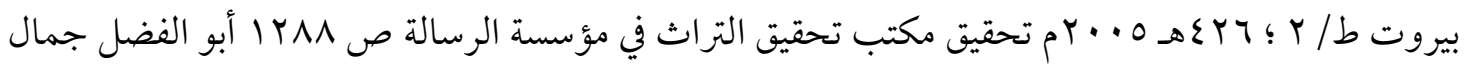

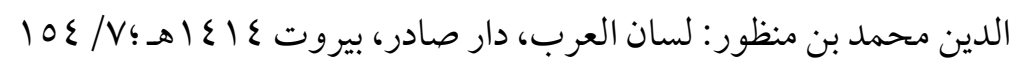

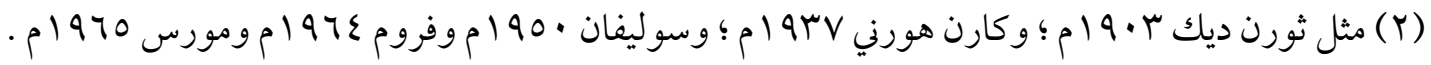
(r) د. دينا يحيى : العوامل المؤثرة في الرضا الوظيفي للقائم بالاتصال في قنوات التليفزيون المحلية ؛ مجلة

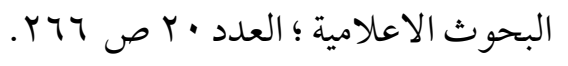

(ع) منى الحاج: الرضا الوظيفي لدى العاملات في العلاقات العامة في بعض المؤسسات الإماراتية ؛ مجلة العلوم

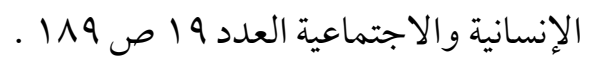


ونظر الهذا الاهتمام فقد ظهرت تعريفات لمصطلح الرضا الوظيفي نذكر منها: فقد عرفه البعض (1): بأنه " أحاسيس أو مشاعر الموظف واتجاهاته نحو وظيفته التي يؤديها؛ وتتحدد درجة الرضا الوظيفي بناء على مقارنة الفرد بين ما يتوقع الحصول عليه من وظيفته وبين ما يحصل عليه منها فعلاً" . وعرفه البعض (r): بأنه " الشعور النفسي بالقناعة والارتياح أو السعادة لإشباع الحاجات والرغبات والتوقعات من العمل نفسه (محتوى الوظيفة) وبيئة العمل، مع الثقة والو لاءو الانتماء للعمل، ومع العوامل والمؤثرات البيئية والخارجية ذات العلاقة" ويرى البعض (r) أن الرضا الوظيفي هو عبارة "عن الشعور الإيجابي أو السلبي للفرد العامل تجاه بيئة العمل، ودرجة قناعته بأن ما يتقاضاه من مكافئات مادية ومعنوية مناسبة مقابل جهوده التي يبذلها في العمل " . بينما يرى البعض () أن الرضا الوظيفي هو عبارة عن " اشباع حاجات الفرد المادية

(1) Lim's " Job satisfaction of information Technology workers: in academic libraries; library\& information science research; vol.30، no.2، 2008، p.5.

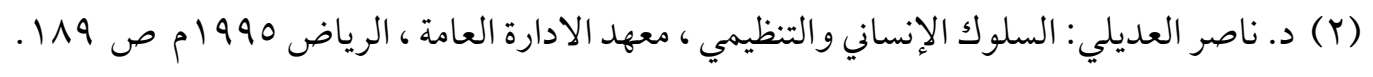

د. بشرى عباس محمد: تأثير الرضا الوظيفي في الأداء المنظم، دراسة تحليلية في الشركة العامة لصناعة

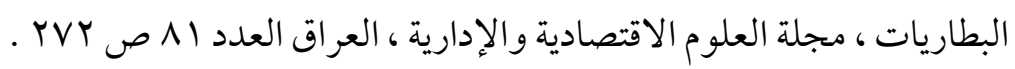

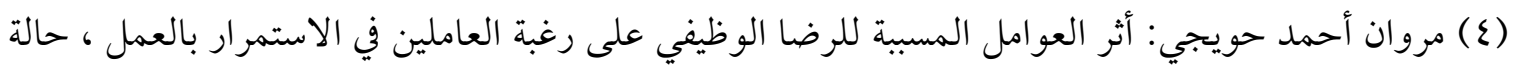
دراسة على اتحاد لجان العمل الصحي في قطاع غزة، رسالة ماجستير في كلية التجارة بالجامعة الإسلامية

$$
\text { . } 11 \text { ص r..人 }
$$

وللمزيد من التعريفات المتعددة للرضا الوظيفي يراجع، محمد عافت شافان العنزي: أثر الحوافز في تحقيق الرضا الوظيفي في المؤسسة العامة للتأمينات الاجتماعية في دولة الكويت، رسالة ماجستير في الإدارة العامة، جامعة آل

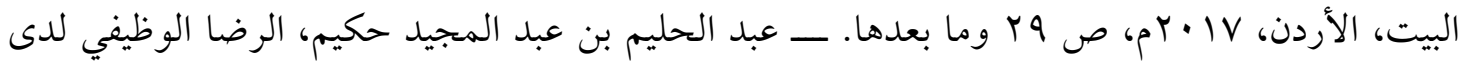


والمعنوية من خلال العمل؛ ويعتبر الرضا هو الاتجاه الإيجابي الذي يحمله الفرد نحو عمله وهو انعكاس لمدى الاشباع الذي يستمده من هذا العمل؛ وبذلك فهو يشير إلى وبري

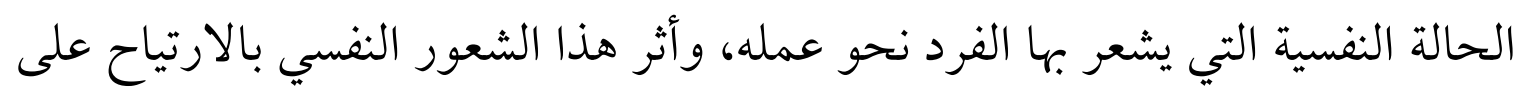
أداء الإنسان وو لائه وانتمائه للمنظمة التي يعمل بها " .

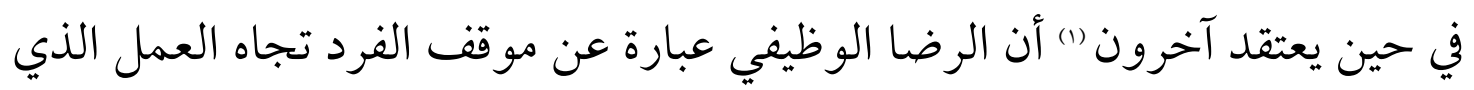
يؤديه، ويكون نتيجة لإدراكه لعمله؛ أو تجاه راتب؛ والترقية، والرئيس، والزملاء، ومحيط العمل، والأسلوب السائد في المعاملة، وفي اجراءات العمل اليومي، أو هو درجة شعور الفرد بمدى اشباع الحاجات التي يرغب في اشباعها من وظيفته الحالية. ومن خلال التعريفات السابقة يمكن استخلاص الخصائص التالية للرضا الوظيفي: اـ أن الرضا الوظيفي عبارة عن مجموعة من الأحاسيس الكامنة داخل الموظف العام يستدل عليها من خلال سلوكه الإيجابي وتميزه في أداء عمله . r ـ الرضا الوظيفي أمر نسبى يختلف إلى حد كبير من موظف إلى آخر والسبب في ذلك

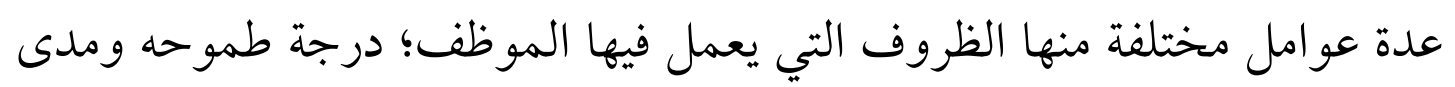

معلمي التعليم العام ومعلمي الفئات الخاصة من الجنسين، دراسة مقارنة؛ رسالة ماجستي؛؛ جامعة أم القرى،

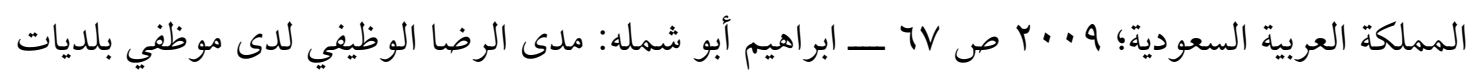

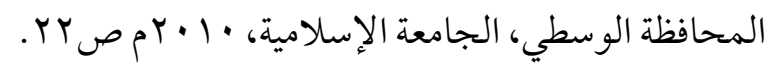

(1) إيمان جوده، ورنده الباقي: العلاقة بين البيروقراطية، ضغوط العمل، وعدم الرضا، دراسة حالة (مجلة العلوم الإدارية؛ جامعة الملك سعود؛ الرياض؛ rrع (هـ r.+rم المجلد (10) ؛ العدد (1) ؛ ص 9 (1. د. محمد إبراهيم التويجري: المواقف الوظيفية والرضا الوظيفي للعاملين من السعوديين وغير السعوديين في الشركات

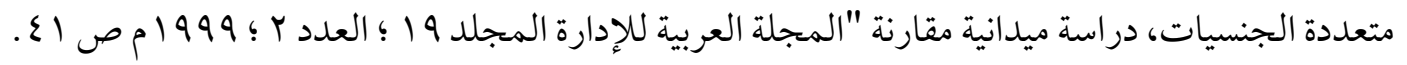


تكيفه مع عمله؛ تعامله مع رؤسائه وزملائه؛ اشباع حاجاته؛ وتلبية رغباته. rـ على الرغم من أن الرضا نسبي لاختلاف العوامل المؤثرة فيه؛ إلا أنه يظل الراتب من أهم، بل أهم عامل مؤثر في رضا الموظف العام عندما يكون مشبعَّ لحاجاته ومحققَّا لرغباته وطموحاته.

عــ يتنوع الرضا الوظيفي إلى نوعين الأول: الرضا العام؛ وهو الاتجاه العام للموظف نحو عمله ككل؛ من حيث كونه راضٍٍ عنه أم غير راضٍ؛ ولا يسمح هذا المؤشر بتحديد الجوانب النوعية التي يرضى عنها الموظف أو التي لا يرضى عنها، أو تلك التي يرضى عنها أكثر من غيرها؛ فهذا النوع يفيد في إلقاء نظرة عامة على موقف الموظف إزاء وظيفته • والنوع الآخر الرضا النوعي؛ ويشير إلى رضا الموظف عن كل جانب من جو انب عمله بشكل مستقل؛ وتتمثل تلك الجو انب في سياسية الادارة التي يعمل تحت مظلتها؛ بما فيها المرتبات؛ فرص الترقي؛ الرعاية الصحية والاجتماعية؛ وغيرها من علاقات العمل وبيئته، وهذا النوع يفيد في تمكين الباحثين في الوقوف على العوامل التي تسهم في خفض الرضا أو زيادته(1) ومن جماع ما تقدم يمكن لنا تعريف الرضا الوظيفي بأنه؛ شعور داخلي بالارتياح النفسي و الطمأنينة ينعكس على سلو كه وأدائه لو اجبات وظيفته نابع من اشباعه لحاجاته وتحقيقه لرغباته واطمئنانه على مستقبله ومستقبل من يعول .

(1) طريف شوقي فرج : السلوك القيادي وفاعليته الإدارية؛ دار غريب للنشر والتوزيع؛ القاهرة r..rم، ص 


\section{الفرع الثاني \\ أهمية الرضا الوظيفي}

يعد الرضا الوظيفي بمغهومه السابق المحرك الأول والأهم لنشاط الموظف العام وتفانيه لعمله؛ فالموظف العام يقضى وقتًا كبيراً من حياته في وظيفته؛ الأمر الذي يجعل الوصول إلى قناعة ورضا الموظف عن عمله أمر في غاية الأهمية لآثاره الإيجابية على الموظف ذاته وعلى المنشأة التي يعمل بها و المجتمع الذي يعيش فيه بشكل عام . فالموظف الراضي عن وظيفته سيطور من أدائه وينمى قدراته؛ مما يزيد من ابداعاته في القيام بواجبات وظيفته؛ الأمر الذي يعود بالإيجابيات على المرفق الذي يعمل به و المتعاملين مع هذا المرفق . والموظف الذي يجيد ويتقن القيام بعمله يعطي انطباعًا حسنَّ للآخرين، سواء كانوا متعاملين مع المرفق العام أو غير متعاملين؛ مما يرفع من شأن الوظيفة العامة و القائمين على سياستها؛ الأمر الذي يعود بالنفع على المجتمع كله . ويمكن تلخيص أهمية الرضا الوظيفي في النقاط التالية') : اـ تحقق الرضا الوظيفي لدى الموظف العام يؤدي إلى ارتفاع درجة الطموح لديه؛ مما

(1) يراجع في ذلك على فالح المطيري: أثر المناخ التنظيمي في الرضا الوظيفي لدى العاملين في البنوك التجارية في

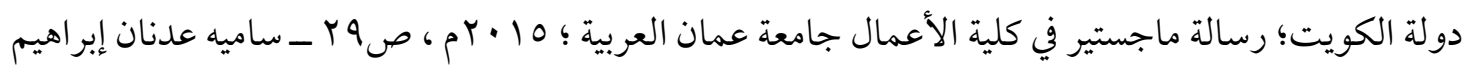
العجوري: العوامل المؤثرة في الرضا الوظيفي لدى الصحفيات الفلسطينيات في فلسطين؛ دراسة ميدانية؛ رسالة

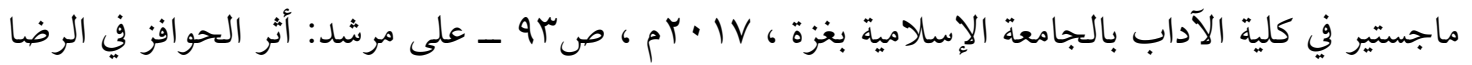
الوظيفي في الشركات الصناعية العاملة في منطقة الملك الحسين بن طلال التنموية في المفرق، رسالة ماجستير

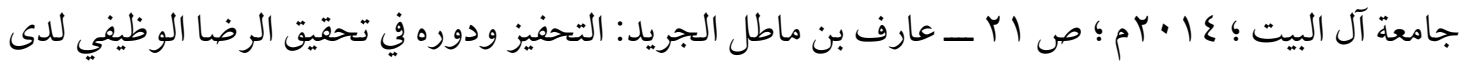
العاملين بشرطة منطقة الجوف، دراسة ميدانية على ضباط وأفراد شرطة منطقة الجوف، رسالة ماجستير كلية الدراسات العليا، جامعة نايف العربية للعلوم الأمنية السعودية ؛ ص ^r. 
يزيد من كفاءته في انجاز عمله؛ علاوة على ارتفاع الروح المعنوية لديه؛ الأمر الذي يدفعه إلى الإبداع والابتكار وتطوير ذاته؛ وبذلك يكون الموظف أكثر قدرة على تلى التكيف الاجتماعي؛ وأقل عرضة للاضطراب والقلق النفسي؛ ويرتفع شعوره بالسعادة؛ ويطمئن على مستقبله .

فالرضا الوظيفي يؤدي إلى تحقيق الأمن والاستقرار النفسي والفكري والوظيفي لدى الموظف العام؛ ويبعث روح الأمل والطموح لدى الموظفين الآخرين في الوصول

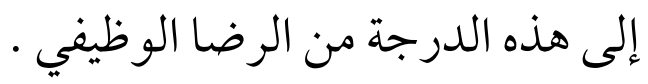

rـ إن ارتفاع درجة الرضا الوظيفي يعود بالنفع على المرفق العام أو المؤسسة التي

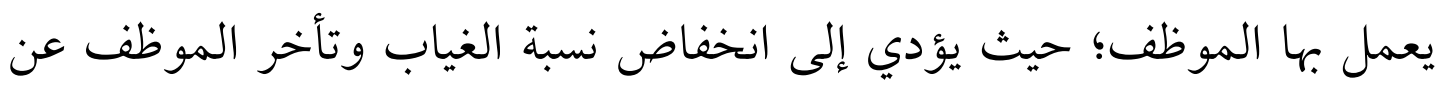

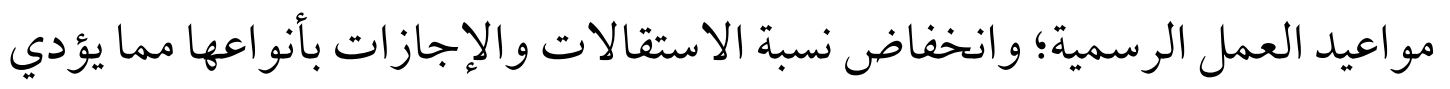
إلى انخفاض معدل التمارض وإصابات العمل، وتدني معدل التظلمات والشكاوى وعدم الاهتمام، هذا فضلاً عن ما يحققه الرضا من انتماء وو لاء الموظف لوظيفته، الأمر الذي يؤدي إلى زيادة مستوى الكفاءة والفاعلية في المؤسسة ، وزيادة الانتاجية

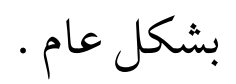

rـ كما أن الرضا الوظيفي يؤثر بشكل إيجابي على المجتمع، فإتقان الموظف لعمله سوف يؤدي إلى ارتفاع معدلات الانتاج والكفاءة الاقتصادية، ومن ثم تطوير المرفق العام بشكل مستمر، الأمر الذي يؤدي إلى ارتفاع معدلات التنمية بشكل عام والتطوير بالمجتمع وتحقيق الاستقرار الأسري وانخفاض معدل البطالة، وتماسك المجتمع بشكل عام .

ونخلص مما سبق، إلى أن الرضا الوظيفي له آثار إيجابية على الموظف والوحدة 
الإدارية والمجتمع، كما أن عكسه له آثاره السلبية').

ولو نظرنا إلى الشريعة الإسلامية نجد أن الرضا فيها بشكل عام معتبر شرعَّ، فقد خاطب المولى سبحانه وتعالى رسوله الأمين بقوله تعالى " ولسوف يعطيك ربك فترضى "(r). فالمولى سبحانه وعد نبيه أنه سيرضيه"(r) بعطائه ليرتاح باله ويطمئن قلبه. ولأهمية الرضا في شعور الإنسان بالسعادة والاطمئنان، مما يدفعه للجد والاجتهاد في عمل الخير لنيل رضا ربه ، قال سبحانه في حق الصادقين " رضي الله عنهم ورضوا عنه ذلك الفوز العظيم()" وقال في حق السابقين الأولين من المهاجرين والأنصار " رضي الله عنهم ورضوا عنه وأعد لهم جنات تجري من تحتها الأنهار خالدين فيها أبدا"(0) ، وقال في شأن الذين آمنو اوعملو ا الصالحات " رضي الله عنهم ورضوا عنه ذلك لمن خشي ربه "(7) - (7)

(1) للمزيد من الآثار الإيجابية للرضا الوظيفي والسلبية لعكسه يراجع ، أندرو دي سيزلاي ، مارك جي والاس :

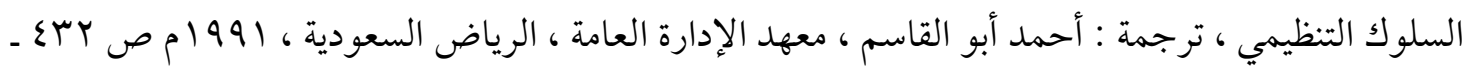

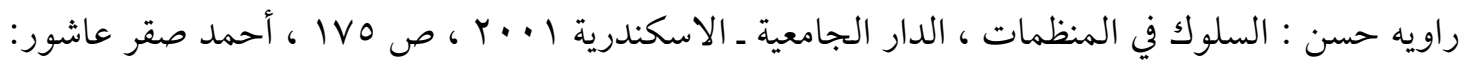

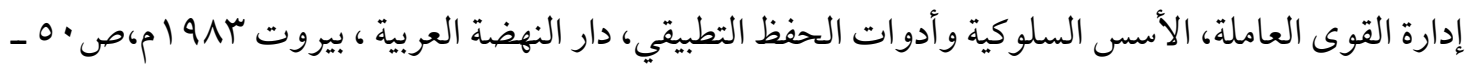
نور الدين شنوفي: تفعيل تقييم أداء العامل في المؤسسة العمومية الاقتصادية، دكتوراه جامعة الجزائر ه ○ ب م

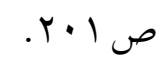

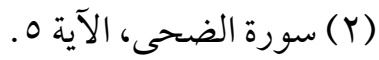

(r) عبد الله بن عبد الرحمن بن العزيز : تأسيس التقديس في كشف تلبيس داود بن جرجيس، مؤسسة الرسالة،

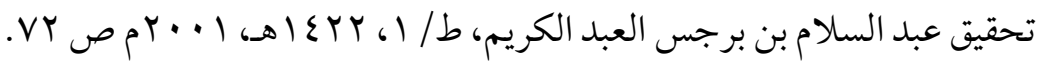

$$
\begin{aligned}
& \text { سورة المائدة الآية } 119 . \\
& \text { (0) سورة التوبة من الآية ... . . } \\
& \text { المورة البينة من الآية } 1 \text { ــ }
\end{aligned}
$$


وقد جاء الرضا في القرآن الكريم ضد السخط ،حيث قال سبحانه في وصفه لحال المنافقين الذين يعيبون على النبي صلى الله عليه وسلم قسمته في الصدقات " ومنهم من يلمزك في الصدقات فإن أعطوا منها رضوا و إن لم يعطوا منها إذا هم يسخطون "(1)، كما ورد بنفس المعنى في السنة المطهرة ، حيث كان من دعاء النبي صلى الله عليه وسلم " اللهم إني أعوذ برضاك من سخطك ،ومعافاتك من عقوبتك .... "().. وقد تعرض الفقهاء لتعريف الرضا، فالرضا عند أهل التصوف هو سرور القلب بمر القضاءs)

وقيل هو انتفاء الجزع في أي حكم كان ، وقال البعض ، هو استقبال الاحكام بالفرح ،

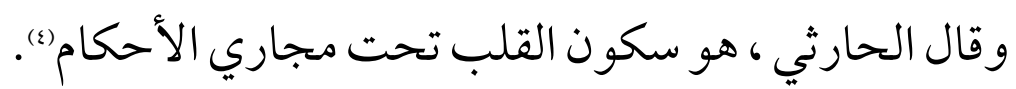
وقد عرف البعض الرضا بالاطمئنان، حيث قال مجاهد في تفسير قوله تعالى " يا أيتها النفس المطمئنة ارجعي إلى ربك راضية مرضية "(م)، المطمئنة أي الراضية (1).

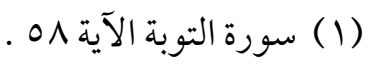

(Y) أبو الحسن مسلم بن الحجاج القشيري النيسابوري: صحيح مسلم ، تحقيق محمد فؤاد عبد الباقي ، دار إحياء

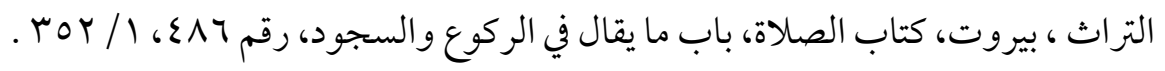

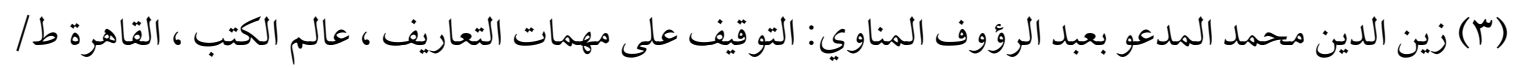
.IV^ 199.

(ع) أبوبكر محمد بن ايوب ابن قيم الجوزية : مدارك السالكين بين منازل اياك نعبد واياك نستعين ، تحقيق محمد

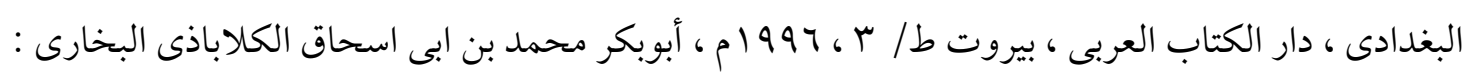

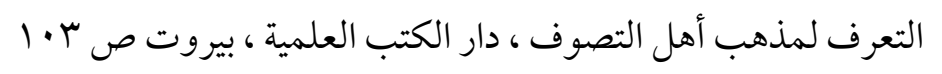

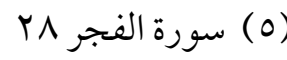

(7) أبو عبد الله محمد بن أحمد شمس الدين القرطبى : الجامع لأحكام القرآن (تفسير القرطبى ) ، تحقيق / أحمد 
وقد يأتي الرضا مر ادف للقناعة، ومن رضي وقنع بأمر، سهل عليه القيام به وحفظه وقام

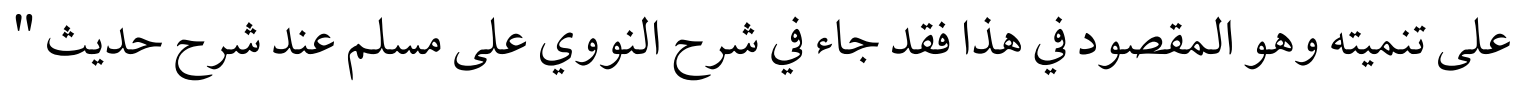
ذاق طعم الإيمان من رضي بالله ربًّا وبالإسلام دينًا وبمحمدٍ صلى الله عليه وسلم نبيَّا

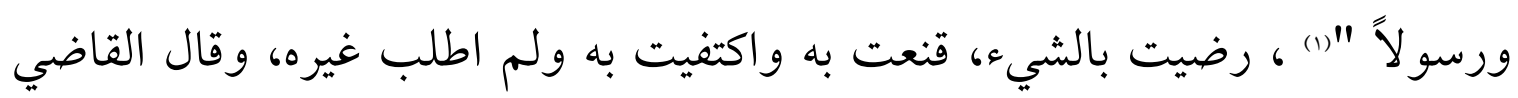
عياض، معنى الحديث أي صح إيمانه واطمأنت به نفسه وخامر باطنه، لأن رضاه بالمذكورات دليل ثبوت معرفته ونفاذ بصيرته ومخالطة بشاشته قلبه ، لأن من رضي أمراً سهل عليه به("). ومما سبق يتضح لنا أن الرضا عند فقهاء الإسلام من أعمال القلوب فهو مشاعر وأحاسيس داخلية يدل عليها سلوك الإنسان و البشاشة التي تظهر على وجهه • كما يتضح لنا أيضًا أن من رضي بشيء حافظ عليه وقام على تنميته وسهل عليه أداؤه فرضاء الموظف عن وظيفته يجعل قيامه بواجباتها أم يسير ويدفعه ذلك إلى مزيد من الابداع والابتكار.

ويتضح كذلك من النصوص الشرعية السابقة عن الرضا، مدى أهميته في علاقة الإنسان مع ربه ومع المجتمع الذي يعيش فيه . وخلاصة ما سبق ذكره في هذا المبحث، أن هناك اتفاق بين النظم الوضعية والشريعة الإسلامية في مفهوم الرضا الوظيفي وأهميته بالنسبة للموظف والوظيفة والمجتمع،

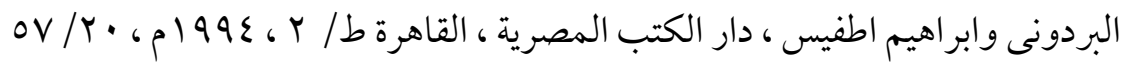

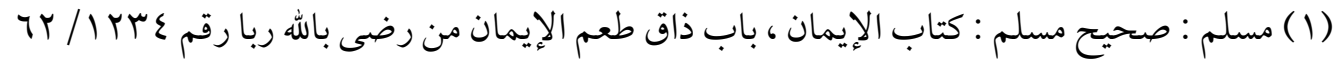

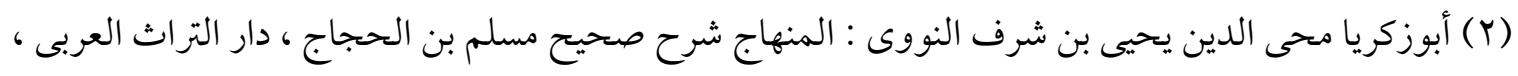

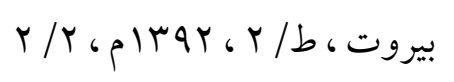


ولابد من وضع رضاء الموظف العام عن وظيفته في عين الاعتبار لانعكاس ذلك على كفاءته في أداء و اجبات وظيفته.

\section{المطلب الثاني \\ أنواع الرضا الوظيفي وخصائصه}

سبق القول بأن الرضا الوظيفي هو شعور داخلي بالارتياح النفسي لدى الموظف العام تجاه عمله و البيئة المحيطة به ، وأن درجة هذا الشعور ليست واحدة عند جميع الموظفين إنما هي نسبية تختلف من موظف إلى آخر، ويرجع هذا الاختلاف إلى عوامل داخلية لدى الموظف العام وأخرى خارجية، وعلى الرغم من ذلك يو جد قدر يكاد يكون متفق عليه من جل الموظفين يتمثل في الرضا العام بالوظيفة. ومن هنا نجد أن البعض (1) قد قسم الرضا الوظيفي إلى عدة أنواع من حيثيات مختلفة كالتالي:

$$
\text { أولاً: من حيث شموليته: - ائ }
$$

ينقسم الرضا الوظيفي من هذه الحيثية إلى الرضا الوظيفي الداخلي ، وهو مرتبط بالجوانب الذاتية للموظف كشعوره بالتمكن والانجاز والتعبير عن التراث، والرضا الوظيفي الخارجي، ويتعلق ببيئة العمل الخارجية كطبيعة ونمط العمل، والرضا الكلي العام وهو مجمل الشعور بالرضا الوظيفي تجاه الأبعاد الداخلية و الخارجية معا .

(1) يراجع إيناس فؤاد فلبمان: الرضا الوظيفي وعلاقته بالالتزام التنظيمي لدى المشرفين التربويين والمشرفات التربويات ، بإدارة التربية والتعليم بمدينة مكة المكرمة، رسالة ماجستير، جامعة أم القرى، المملكة العربية 
وقد رد البعض الأنواع الثلاثة السابقة للرضا الوظيفي إلى نوعين رئيسيين هما (1): الأول : الرضا العام عن الوظيفة: ويشير هذا النوع إلى الشعور العام للموظف تجاه عمله بشكل عام، هل هو راضي عن عمله أم غير راضٍ؟ فهو يمثل رضا الموظف عن جميع جوانب ومكونات الوظيفة، ولا يسمح هذا النوع بتحديد الجوانب النوعية التي يرضى عنها الموظف أكثر من غيرها، فضلاً عن الجوانب التي لا تحوز رضاه من الأساس وهذا النوع يفيد في معرفة موقف الموظف تجاه عمله بشكل عام • الآخر : الرضا النوعي (ب) الجزئي ) عن الوظيفة : والذي من خلاله يمكن التعرف على الشعور الوجداني للموظف عن جزء أو بعض مكونات الوظيفة كمدى رضاه عن طبيعة الوظيفة وسياسة تعامل الرؤساء والتعامل مع الزملاء ، ومدى رضاه عن راتبه ، وأساليب الترقية، وغير ذلك من العو امل التي تسهم في خفض أو زيادة الرضا الوظيفي (r).

ثانيًا : من حيث الزمن : ينقسم الرضا الوظيفي باعتبار زمنه إلى قسمين الأول : الرضا الوظيفي المتوقع، ويشعر الموظف بهذا النوع من خلال عملية الأداء الوظيفي إذا كان متوقعَّا أن ما يبذله من جهد يتناسب مع هدف المهمة. الآخر : الرضا الوظيفي الفعلى ، ويشعر الموظف بهذا النوع من الرضا بعد مرحلة الرضا الوظيفي المتوقع، عندما يحقق

(1) طريف شوقي فرج: السلوك القيادي وفعاليته الإدارية ، دار غريب للنشر والتوزيع ، ط/ ا القاهرة ، مصر

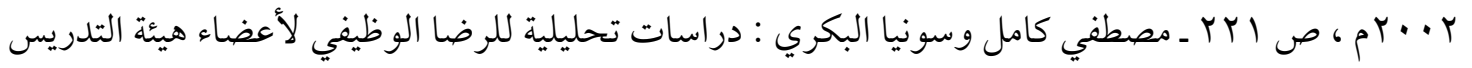

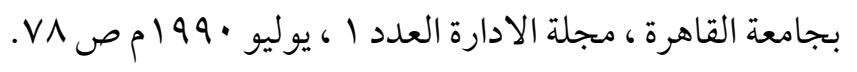

(Y) والرضا النوعي عن الوظيف كان أهم الأسباب التي جعلتني أقصر بحثي هذا على أهم العوامل المؤثرة في رضاء الموظف عن عمله وهو الراتب ، لأن جل الموظفين إن لم يكن جميعهم يهدف من وراء التوظف إلى

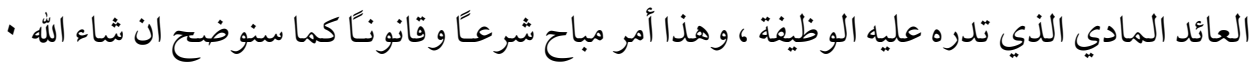


الهدف، فيشعر حينها بالرضا الوظيفي.

خصائص الرضا الوظيفي: للرضا الوظيفي جملة من الخصائص يمكن تلخيصها فيما

اـ يعد الرضا الوظيفي مسألة ذاتية تقديرية مرتبطة بالمشاعر التي قد يعبر عنها السلوك الذي يعكس حالة الموظف، ومن هنا يمكن القول بأن الرضا الوظيفي قد يكون

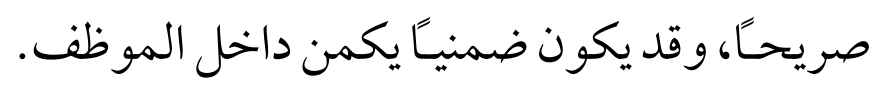

r_ النظر إلى الرضا الوظيفي على أنه موضوع فردى ، فما يعد رضا لشخص قد يكون عدم رضا لغيره، مما يترتب عليه تعدد واختلاف طرق قياس الرضا الوظيفي ، كما أن

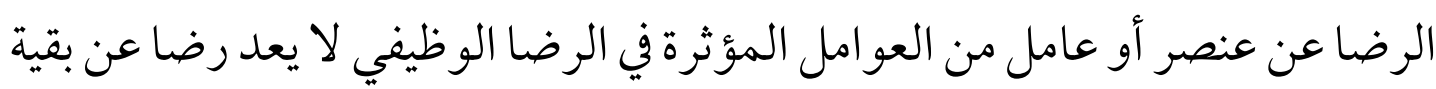
العناصر، هذا فضلاً عن اختلاف درجات الرضا من موظف لآخر لاختلاف تأثرهم

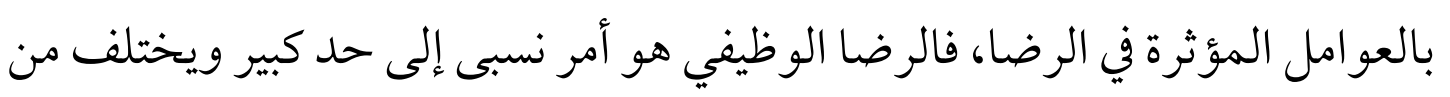

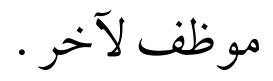
rــ فضلاً عن أن الرضا الوظيفي قد يختلف من موظف لآخر فإنه قد يختلف لدى

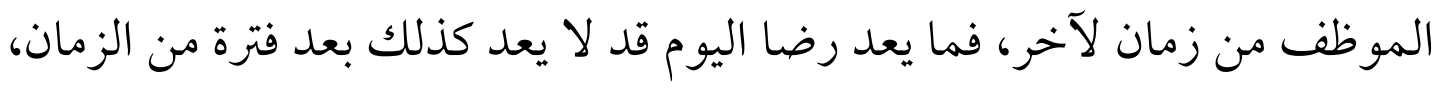
خاصة الرضا عن الراتب، نظرا لارتفاع سقف احتياجات الموظف وتقلبات

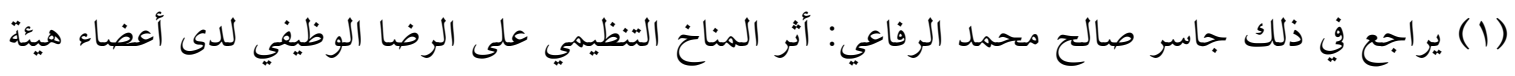

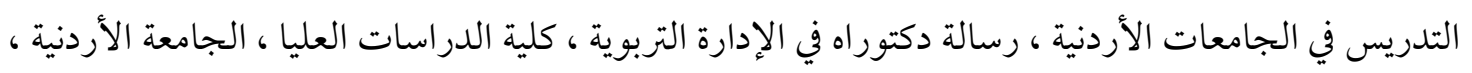

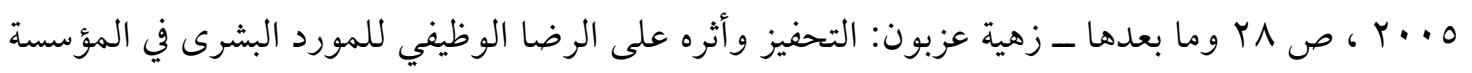

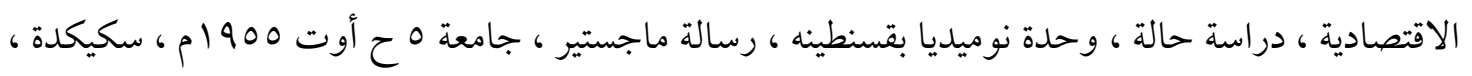

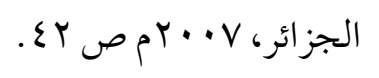


الأسعار، ومن هنا يمكن القول بأن الرضا الوظيفي يجب قياسه والنظر فيه من فترة

$$
\text { لأخرى، وتنميته بشكل مستمر . }
$$

وقد تحدث فقهاء الإسلام") عن الرضا وأنو اعه وآثاره بشكل عام وقيدوه بالتسليم والانقياد لله سبحانه ، وقد فرقوا بين الرضا بالله والرضا عن الله ، فالأول : الرضا بأنه الله

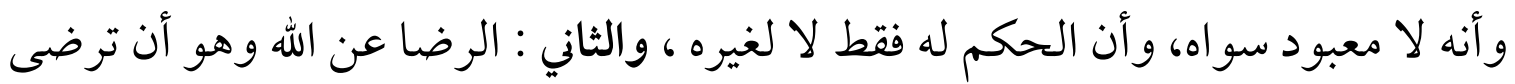
بما قضى وقدر، أي تكون راضيكاعن ربك فيما أحدث وخلق من المقادير("). وهذه التفرقة تشبه إلى حد كبير تقسيم الرضا الوظيفي، إلى رضا عام، أي قبول الوظيفة بشكل عام، ورضا نوعي، وهو الرضا عن بعض عناصر الوظيفة، أو التسليم - بآثارها وقد تحدث الفقهاء عن ثمرات الرضا وآثاره، وقد ذكروا للرضا ما يقرب من ثلاث عشرة ثمرة، من أهمها، أن الرضا من أعمال القلوب وأن ثمرة وجوده رضا الرب عن

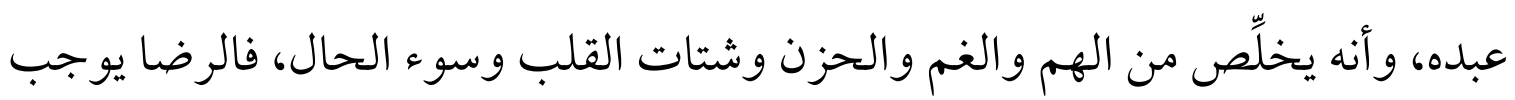
طمأنينة القلب وبرده وسكونه، ويفتح باب السلامة من الغش والحقد والحسد، وأن

(1) ابن القيم : مدارك السالكين ، /110/ وما بعدها ، محمد نصر الدين محمد عويضه، فصل الخطاب في الزهد

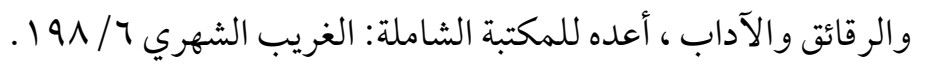

(Y) وذكر شيخ الاسلام ابن تيمية أن الرضا نوعان : أحدهما الرضا بفعل ما أمر به وترك ما نهي عنه ، ويتناول ما

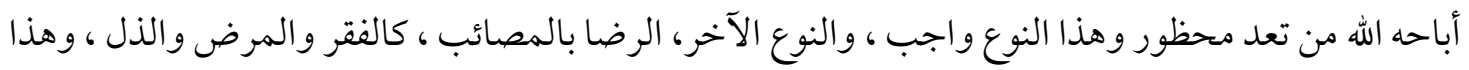
النوع من الرضا مستحب على أصح الأقوال ، راجع نصرة النعيم في مكارم أخلاق الرسول الكريم صلى الله

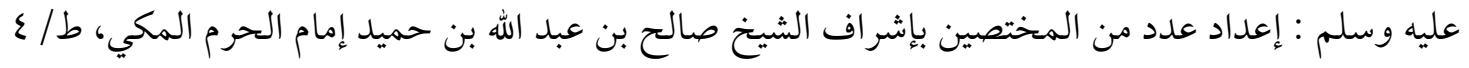

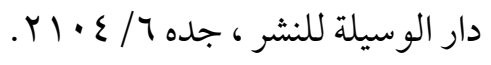


الرضا يصفي الذهن فيتتفع صاحبه بما يعمل (1)، فالرضا له شأن عجيب على سلوك الموظف، لأنه من أعمال القلوب التي تجعله يُقبل على القيام بواجبات عمله بأريحية وقناعة، وبذلك يكون هناك تقارب بين النظم الوضعية والشريعة الإسلامية فيما يتعلق

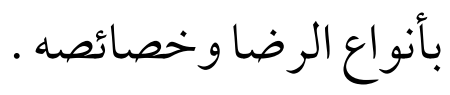

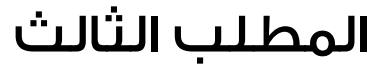 العوامل المؤثرة في الرضا الوظيفي}

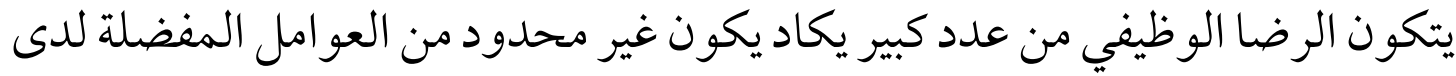
كل موظف، وعلى الرغم من ذلك يوجه شبه اتفاق على المجالات الواسعة التي يكون فيها إرضاء الموظف العام ضروريكً، وهذه المجالات في حقيقتها هي عوامل الرضا

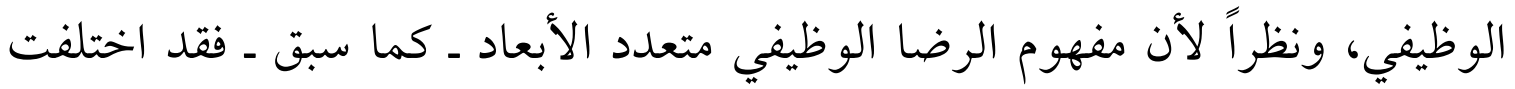
الأبحاث في تسمية هذه الأبعاد، فقد ذكرها البعض على أنها أبعاد الرضا الوظيفي(") ،

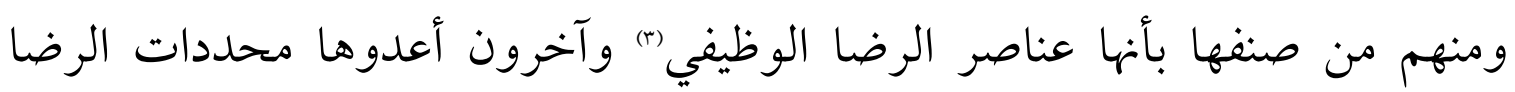
الوظيفي في حين اعتبرها البعض عوامل مؤثرة في الرضا الوظيفي()، وعلى الرغم من

(1) يراجع في ثمر ات الرضا محمد نصر الدين عويضه : فصل الخطاب في الزهد والرقائق والآداب ،/T. ب وما بعدها.

(r) راشد طاحوس بعد الجعيرى الزعبى : مستوى الرضا الوظيفي لدى المشرفين التربويين في المنطقة الشرقية

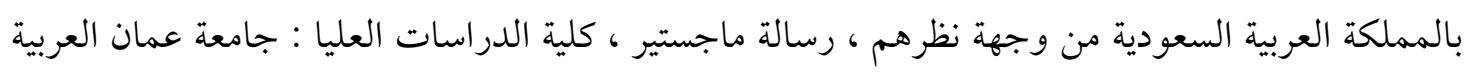

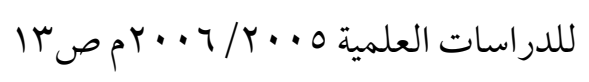

(r) محمد عافت العنزي : أثر الحوافز في تحقيق الرضا الوظيفي في المؤسسة العامة للتأمينات الاجتماعية في دولة

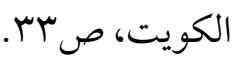

(ع) على المطيري : أثر المناخ التنظيمي ، الرضا الوظيفي ص بr. ـ ـههد الخشاب: أثر الرضا في الارتباط الوظيفي

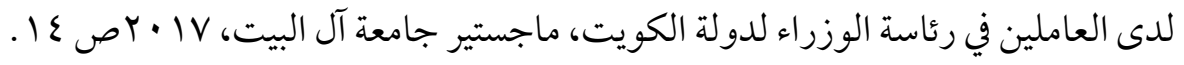




\section{اختلاف المسميات فإن مضمونها واحد .}

وقد تعددت وجهات النظر حول العوامل المؤثرة على الرضا الوظيفي نظراً لكثرتها من ناحية، ولتعلقها بمتغير ات كالموظف نفسه وبيئة العمل .

وقد سلك الباحثون مسالك متعددة في تعداد العوامل المؤثرة في الرضا الوظيفي (1) ويمكن لنا رد العوامل المؤثرة على الرضا الوظيفي إلى ثلاثة أقسام ، عوامل شخصية (ذاتية ) وعو امل تنظيمية، وعو امل اقتصادية .

\section{أولا: العوامل الشخصية (الذاتية):}

وهي العو امل التي ترتبط بالقدرات و المهارات الإبداعية لدى الموظفين، وترتبط أيضا بمستوى الدافعية لديهم، ومدى تأثير دو افع العمل عليهم . وتتعدد العوامل الشخصية المؤثرة في درجة الرضا الوظيفي لدى الموظف العام،

(1) البعض صنف هذه العوامل لعدة مجموعات ، مجموعة العوامل الذاتية ، العوامل التي ترتبط بظروف وبيئة العمل ، العوامل التي ترتبط بالوظيفة ، العوامل التي ترتبط بالإشراف أو القيادة ، العوامل التي ترتبط بتنظيم العمل داخل المؤسسة ، العوامل التي ترتبط بالبيئة التي ينشأ فيها الفرد ، العوامل التي ترتبط بالأمان الوظيفي والأجور وفرص التطور الوظيفي ، راجع ، محمد صلاح الدين عبد الباقي: السلوك التنظيمي ، الدار الجامعية

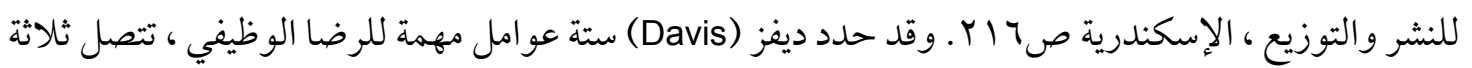
منها بالعمل مباشرة ، والثلاثة الأخرى تتصل بجو انب ذات علاقة بالعمل راجع في ذلك سالم تيسير الشرايده:

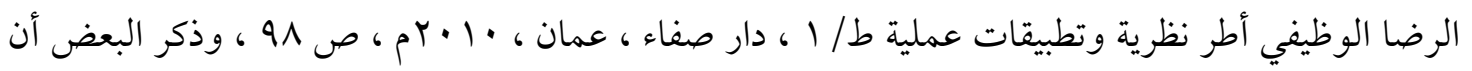

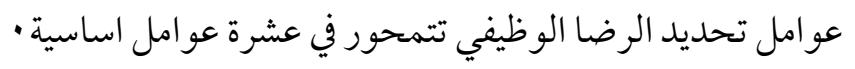

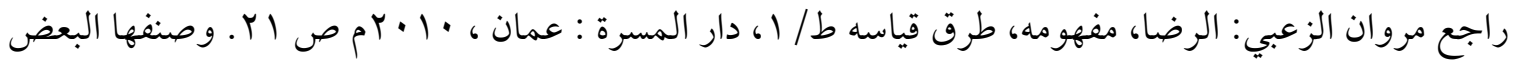
إلى خمس عو امل ، راجع حامد بدر : الرضا الوظيفي لأعضاء هيئة التدريس والعاملين بكلية التجارة والاقتصاد ، و العلوم السياسية بجامعة الكويت مجلة العلوم الاجتماعية، ع/ ب ص 70 ـ 77 
ويمكن الحصول عليها من سجلات الموظفين، إلى أبعاد متعددة نذكر منها"): 1-تقدير الذات والمكانة الاجتماعية : لاشك أن طبيعة الوظيفة والمركز الذي يشغله الموظف العام ونظرة المجتمع لتلك الوظيفة كل ذلك له دور في تحقيق واحترام ذاتية الموظف وشخصيته، فالموظف العام يسعى ـ عادة ـ للحصول على التقدير والاحترام من خلال وظيفته ولقيامه بو اجباتها بكفاءة وليس من شك في أن شعوره بالاحترام والتقدير يدخل في نفسه السرور ويزيد من درجة رضاه الوظيفي (r). فعندما يشير الموظف بأن وظيفته تحقق له مركزاً ومكانة اجتماعية مرموقة، وتكسبه تصنيه احترام وتقدير المجتمع، عندها يشعر الموظف بأن وظيفته هي مصدر فخر وتقدير من المحيطين به، الأمر الذي يزيد من رضاه الوظيفي . r- العمر ومدة الخبرة: يقصد بمدة الخبرة، الفترة الزمنية التي يقضيها الموظف في عمله، وتشير بعض الدراسات والدلائل إلى أن مدة الخبرة للموظف تعتبر من العوامل

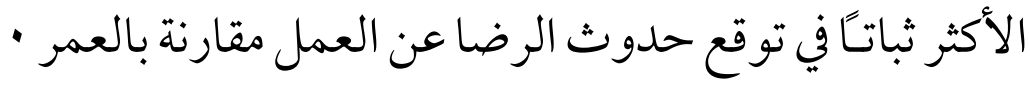
حيث توجد علاقة طردية بين الرضا الوظيفي ومتغير سنوات الخبرة، تعود إلى أن

(1) يراجع في ذلك محمد زين العابدين عبد الفتاح: درجة الرضا الوظيفي لدى أعضاء هيئة التدريس العاملين

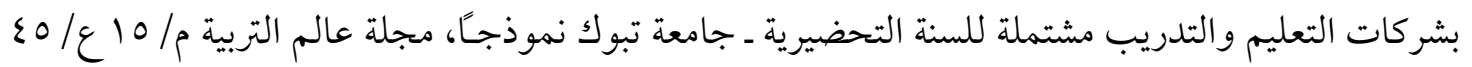
مصر ع ا•r ص 99 ـ جرنبرج جيرالد ، بارون روبرت : ادارة السلوك ، ترجمة رفاعي رفاعي ، وبسيوني

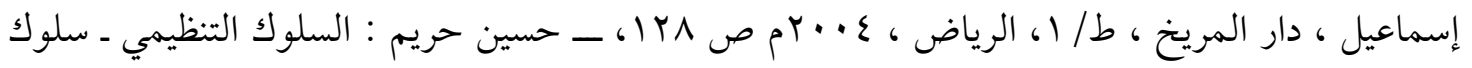

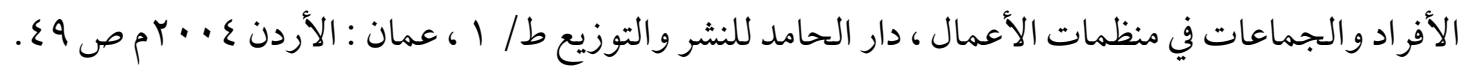

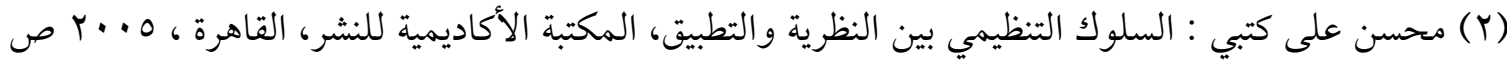


الموظف كلما ازدادت خبرته أصبح أكثر تمكنَّا في عمله ، و من ثم يزداد رضاه الوظيفي "( . r- حاجات الفرد : لكل موظف حاجات تختلف عن حاجات الآخرين في نوعها ودرجة اشباعها وهذه الحاجات تشبع من خلال العمل، فكلما توفر الاشباع المناسب توفر في مقابله الرضا المناسب

عـ القيم واتقان العمل : تعرف القيم بأنها ميل عام لتفضيل حالات وشؤون معينة عن أخرى(r) •، وتختلف القيم باختلاف التخصصات الوظيفية، كما أنها تختلف من موظف لآخر، فبعض الموظفين يؤمن بقيم المال، والبعض يؤمن بقيم المكانة الاجتماعية، والبعض الآخر يؤمن بقيم خدمة المجتمع والآخرين، فبقدر ما تتحقق هذه القيم يتحقق الرضا الوظيفي، ومن هنا تلعب القيم الدور الأساسي في تحديد وتوجيه سلوك الأفر اد بشكل عام • 0ـ القدرات الخاصة : يوجد لكل موظف العديد من نقاط الضعف و القوة والقدرات الخاصة عند أداء واجبات وظيفته، وهذا يعنى عدم تساوى الموظفين في امكانياتهم وقدراتهم، فلكل موظف قدرات خاصة قد لا يشترك معه غيره فيها تؤهله للقيام بواجبات وظيفته، ويمكن تصنيف هذه القدرات إلى مجموعتين : (أ) ـ القدرات البدنية : فقد تحتاج أعمال الوظيفة إلى قدرات بدنية مختلفة، من أهمها القوة، وهي مقدرة الموظف على استخدام قدرته وقوته في أداء عمله، والمرونة وتعنى مقدرته

(1) وجدي محيسن : مدى رضا الموظفين العاملين في مؤسسات وكالة الغوث في قطاع غزة عن أنظمة التعويض

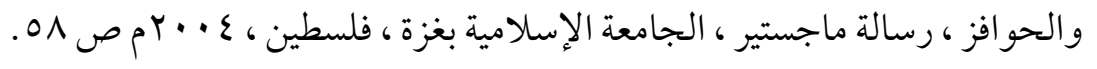

(Y) راويه حسن : إدارة الموارد البشرية، رؤية مستقبلية، الدار الجامعية للطباعة والنشر، ط/ ا، الإسكندرية،

$$
.10 r \text { r p r... }
$$


على تحريك الأجسام بسرعة من وضعية لأخرى، وقوة التحمل، وتعنى مقدرة الموظف على ممارسة أعمال وظيفته لأوقات طويلة وتحمل أعبائها و الصبر عليها ، ومنها السرعة ، وتعنى مقدرة الموظف على الحركة داخل محيط العمل بسرعة"(1) . (ب) ـ القدرات الذهنية(r) : وهي ترتبط بقدرات الموظف على أداء واجبات وظيفيته الذهنية وتتفاوت الحاجة إلى هذه القدرات باختلاف نوع الوظيفة ودرجة الموظف داخلها ، فبالنسبة لمستويات الإدارة العليا تحتاج إلى قدر كبير من هذه القدرات ، لأن اتخاذ القرار يحتاج إلى تفكير وتحليل للمعلومات وتقدير كبير في اختيار الوقت المناسب لإصدار القرار، ومن هذه القدرات، الذكاء الاستنباط والاستنتاج ، والقدرات اللفظية

• والتعبيرية، والسمات القيادية

ولاشك في أن تمتع الموظف بهذه القدرات ( البدنية والذهنية ) يكسبه الثقة وينعكس

بالإيجاب على رضاه الوظيفي

7ـ الشخصية والمؤهلات العلمية(r) : تتمثل الشخصية في مجموعة الخصائص التي يتمتع بها الموظف ويتميز بها عن الآخرين، وهي التي تحدد علاقة الموظف بالمؤسسة وبجميع من يعمل فيها ، وتعد نموذجـا منفرداً ومستقراً في الفكر والسلوك والعواطف، وكلما كانت الشخصية متسقة مع نفسها ومع الآخرين كلما كان

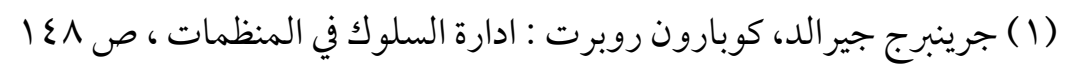

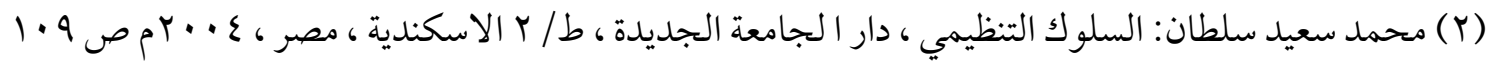
(r) يراجع في ذلك ايمان عبد الباقى : العلاقة بين البيروقراطية وضغوط العمل ، وعدم الرضا الوظيفي ، دراسة

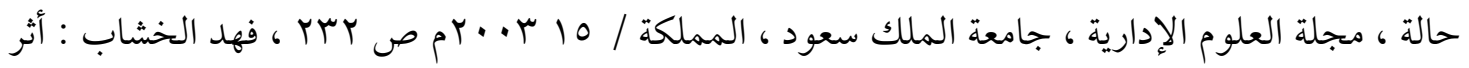
الرضا في الارتباط الوظيفي لدى العاملين في رئاسة الوزراء لدولة الكويت ص 17 


\section{الموظف أكثر انتاجية وأكثر رضا .}

أما بالنسبة لتأثير المؤهل العلمي على الرضا الوظيفي، فقد أثبتت العديد من

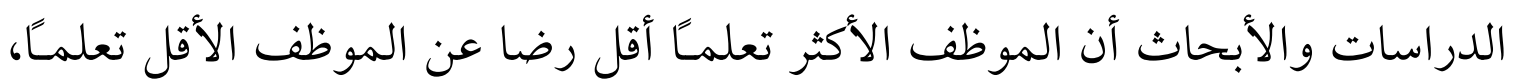
ويرجع ذلك إلى أن تطلعات الموظف الأكثر تعلما تكون مرتفعة دائمًا، وذلك لما يتمتع به من تطور مستمر ، مقارنة بالموظف الأقل تعليمكَ)(1) والذي يرضى بالقليل . ويتضح لنا مما سبق أن درجة الرضا الوظيفي تتأثر بمجموعة عوامل نابعة من ذات شخصية الموظف وهي تختلف من موظف لآخر.

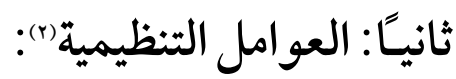
ويقصد بها البيئة الاجتماعية والتنظيمية داخل العمل، فالمناخ التنظيمي له دور كبير في تحديد درجة الرضا الوظيفي لدى الموظف العام • وتوجد عدة عوامل تتعلق بالسلوك التنظيمي للعمل تؤثر على درجة الرضا الوظيفي من أهمها:

1_اسلوب القيادة : يعد الأسلوب الديمقر اطي للقيادة الإدارية هو الأسلوب المفضل لدى الموظفين، حيث يؤدي هذا النمط من الأساليب إلى تنمية المشاعر الإيجابية نحو

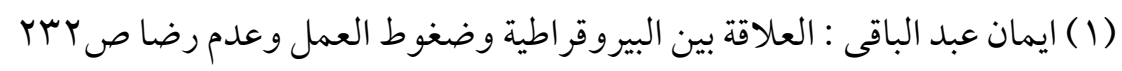

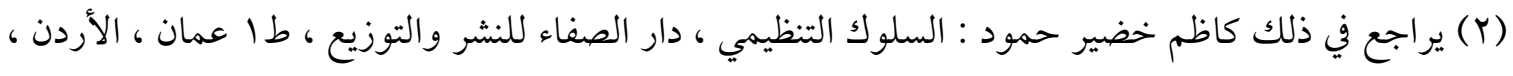

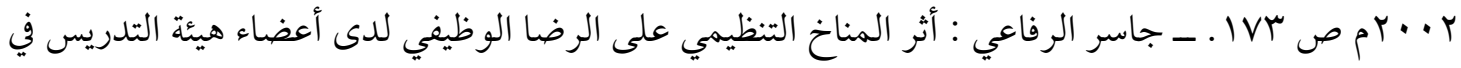
الجامعات الخاصة الأردنية ، ص بع ـ محمود سلمان العميان : السلوك التنظيمي في منظمات الأعمال ، دار

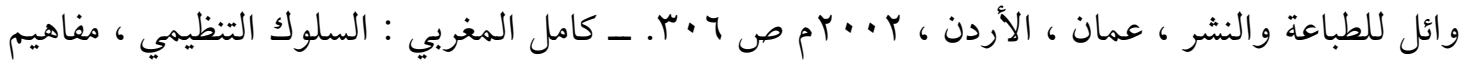
وأسس سلوك الفرد و الجماعة في التنظيم ، دار الفكر للطباعة و النشر والتوزيع ، طץ ، عمان ، الأردن ص ؟ •r. 
عملهم") داخل المؤسسة ويشعرهم بأهميتهم ودورهم الفاعل في رسم السياسة العامة لإدارة المرفق العام الذي يعملون به، وهذا يشعرهم بأهميتهم، ومن ثم يرفع درجة الرضا

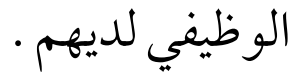

r- طبيعة العمل ()) : العمل غير الروتيني الذي لا يسير على نمط واحد متكرر، يولّد التجدد والتحفيز لدى الموظف، ويدفعه إلى الابداع والابتكار والتجديد في اسلوب أدائه لأعمال وظيفته، ولا شك أن هذا يولد الشعور بقيمة العمل لدى الموظف العام ويرفع من

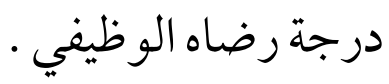

وهذاعكس العمل الروتيني الذي يقتل روح الابداع والتفكير الخلاق لدى الموظف العام ويجعله يمل من أدائه لإعمال وظيفته، وينتظر بفارغ الصبر نهاية أوقات العمل

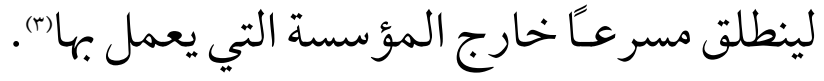

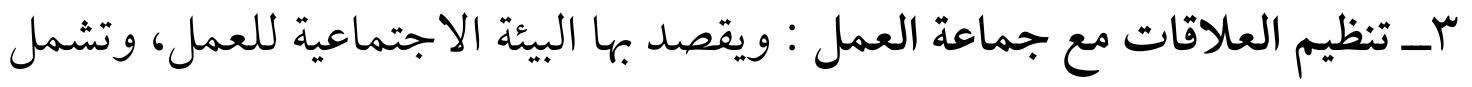
العلاقة مع الرؤساء ومع الزملاء()، فالعلاقة مع الرؤساء المبنية على الود والتفاهم والتقدير للذات يكسب الموظف ثقة في نفسه وقدراته وترفع درجة رضاه الوظيفي ،

(1) سهيلة محمد عباس : إدارة الموارد البشرية ، مدخل استراتيجي ، دار المسيرة للنشر والتوزيع ، عمان ،

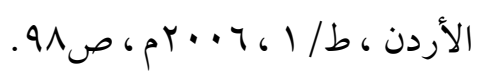

(Y) يقصد بطبيعة العمل ، كون العمل روتينيا ، أي يسير على نمط معين غير متجدد، أو كونه غير روتيني.

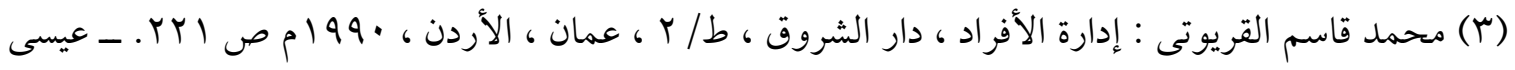
محمد المحتسب : الرضا عن الأداء المهني وعلاقته بالكفايات الارشادية ، دكتوراه جامعة محمد الخامس،

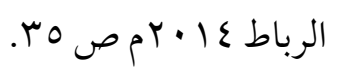

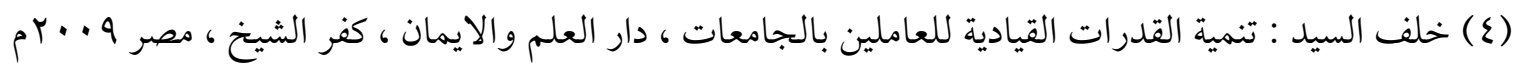


خاصة اذا كانت سياسة الرؤساء قائمة على تفهم ظروف المرؤوسين، وإز الة كافة العقبات التي تعترض طريق تقدمهم في القيام بأعمالهم بمهارة وابتكار. وإذا كانت العلاقة بالرؤساء لها دور بارز في تقدير درجة الرضا الوظيفي ، فإن العلاقة مع الزملاء لا يقل دورها عن ذلك، فعامل العلاقة مع الزملاء يعد من العوامل المؤثرة في الرضا الوظيفي" (1) حيث يسود مناخ العمل في المر افق العامة جملة من العلاقات تتم بين الموظفين تؤثر في الرضا الوظيفي، فكلما كانت العلاقة بينهم قائمة على التفاهم والانسجام، كلما كانت درجة الرضا الوظيفي مرتفعة ، و العكس بالعكس • عــ التدريب والتطوير الدائم لمهارات الموظفين((): يقصد بالتدريب، عملية اكساب المعارف والمهارات للموظفين بهدف رفع كفاءتهم الوظيفية والارتقاء بأدائهم لأعمال وظائفهم للحصول على أعلى انتاجية في زمن قليل وبتكلفة أقل، حيث يعمل التدريب على رفع مستوى الموظفين واطلاعهم على أحدث الوسائل والمستجدات في تقديم الخدمات والقيام بالو اجبات الوظيفية ، فتأهيل وتدريب الموظف و اكسابه المعارف والمهارات له تأثير إيجابي على رضاه الوظيفي لشعوره بالثقة في قدراته ل لقيام بأعمال وظيفته. ○ـــ أسلوب التحفيز المعنوي : لاتباع الرؤساء الأسلوب العادل في التحفيز المعنوي

(1) دينا محي : العوامل المؤثرة في الرضا الوظيفي للقائم بالاتصال في قنوات التليفزيون المحلية ، دراسة ميدانية ،

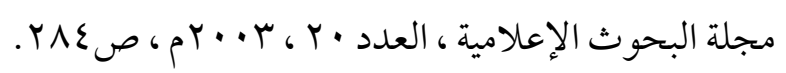
(Y) تيسير أبو عرجة : دراسات في الصحافة والإعلام ، دار مجدلاوي للنشر والتوزيع ، ط/ ا ، عمان ، الأردن،

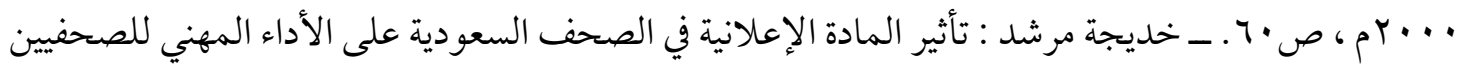

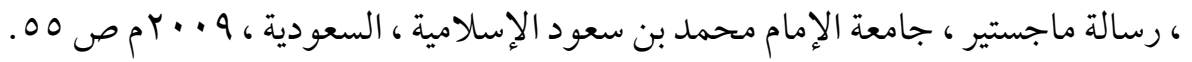


أو التشجيع دور مؤثر في الرضا الوظيفي، فعندما يقوم الرئيس الإداري بتشجيع

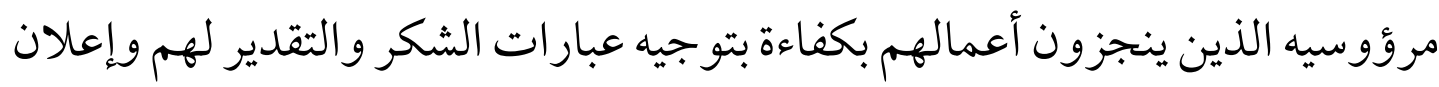

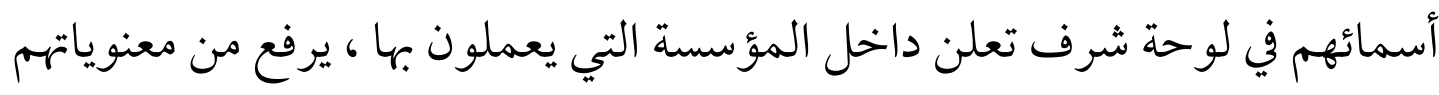

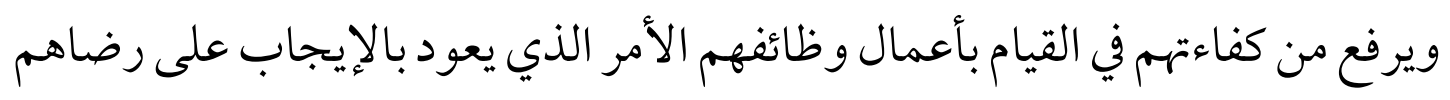
الوظيفي. 7ـ ظروف العمل وبيئتها(1): إن ظروف المكان الذي يؤدي فيه الموظف عمله ، من تأثيث

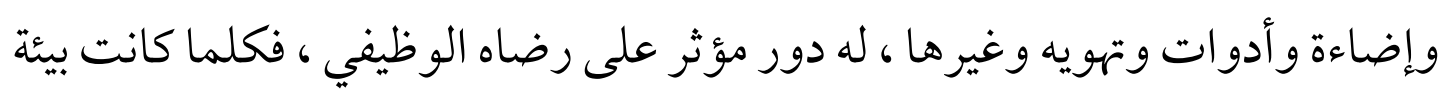

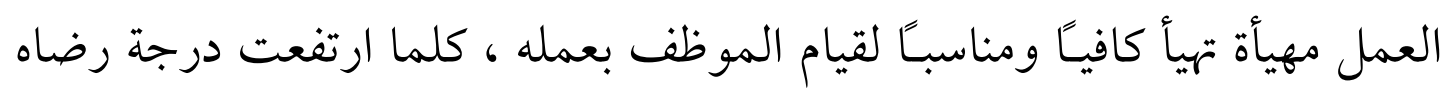
الوظيفي ، وانعكس بالإيجاب على أدائه لو اجبات وظيفته.

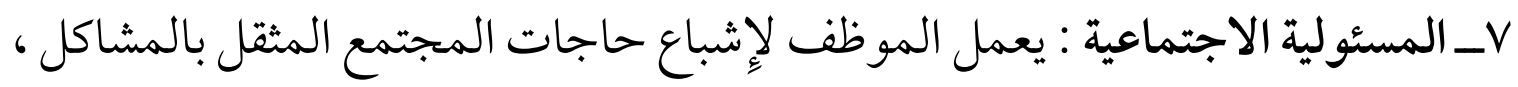

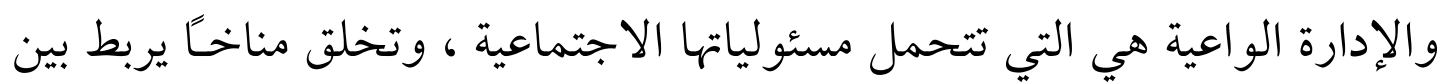

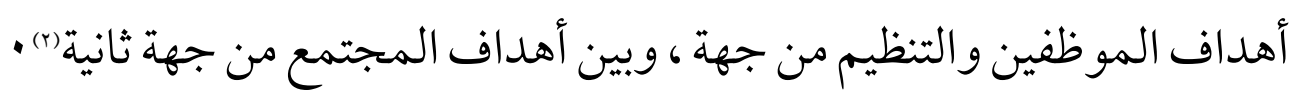
ونخلص مما سبق ، إلى أن العوامل التنظيمية داخل المؤسسة لها دور بارز في تحديد

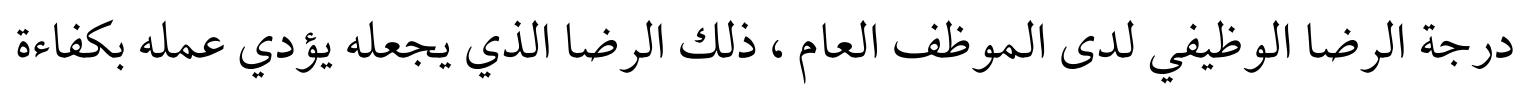

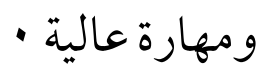

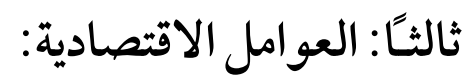

تعد العوامل الاقتصادية من أهم العوامل المؤثرة على الرضا الوظيفي، إن لم تكن

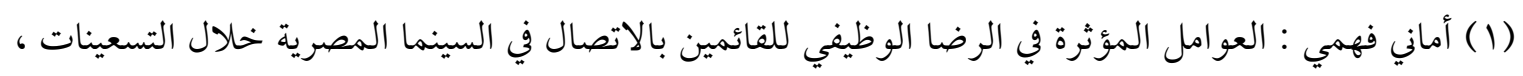

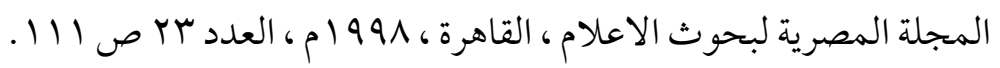

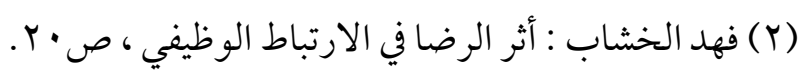


أهمها على الإطلاق ، فالنظرة إلى الوظيفة العامة في أيامنا هذه قد اختلف عما قبل ، فقد كان البعض قديمًا ينظر إلى الوظيفة العامة ـ خاصة المرموقة منها ـ على أنها نوع من الوجاهة وأحد متطلبات المركز الاجتماعي المرموق ، نظراً لأن هؤلاء كانوا يملكون

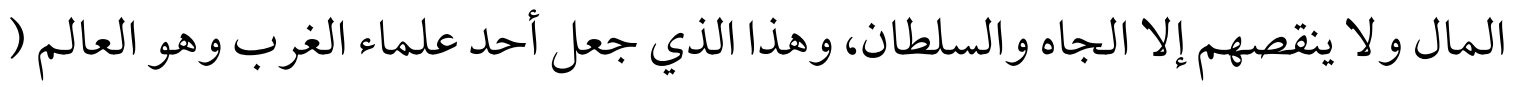
فردريك هيرت زبرج ) في نظريته الشهيرة ( نظرية هيرتز برج ) عام 909 ام والتي أسماها

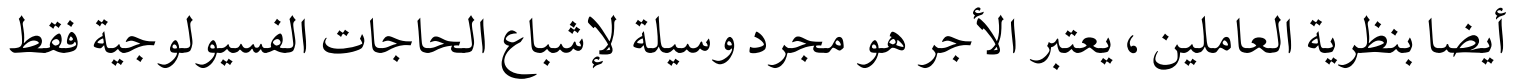
لا غير (1) رغم أنه قد يتعدى ذلك بكثير.

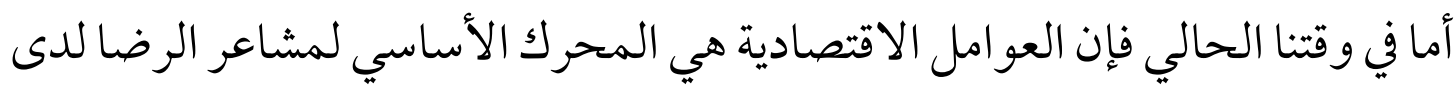
الموظف العام عن وظيفته ، فجُلُ الموظفين العموميين الآن ـ إن لم يكن جميعهم ـ يتوقف رضاه الوظيفي على ما يعود عليه من مزايا مالية عند انخر اطه للعمل في المرافق العامة، فتظل هذه المزايا سواء كانت مباشرة ، كالر اتب والحوافز من مكافآت وبدلات،

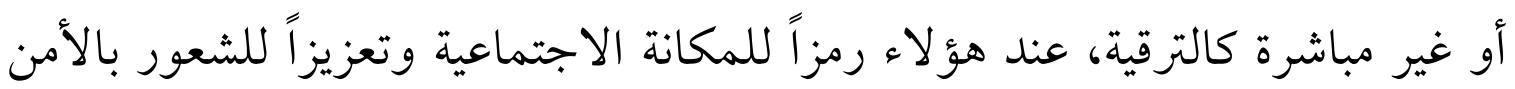
والاستقرار والأمان من تقلبات الزمان، وحصنً منيعًا له ولمن يعول ضد الفقر والاحتياج حال حياته وبعد مماته - ماته فكما ازدادت درجة أمان النواحي الاقتصادية عند الموظف العام ، ازدادت تبعَّ لهما درجة رضاه عن وظيفته وزاد ولاؤه لها، وحرصه على المصلحة العامة والتفاني في القيام

(1) راشد الزعبي : مستوى الرضا الوظيفي لدى المشرفين التربويين في المنطقة الشرقية بالمملكة العربية السعودية

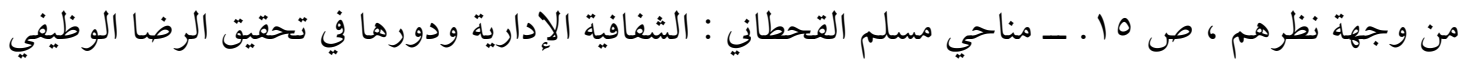

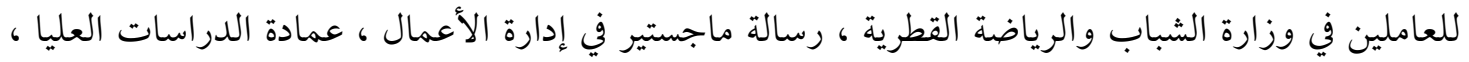

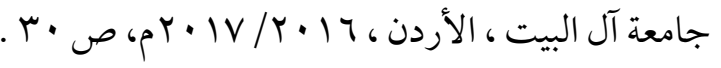


بأعمال وظيفته ، مهما كانت صعوبة هذه الأعمال، ومهما كانت ضغوطات العمل أو سياسة التعامل داخل المؤسسة التي يعمل بها.

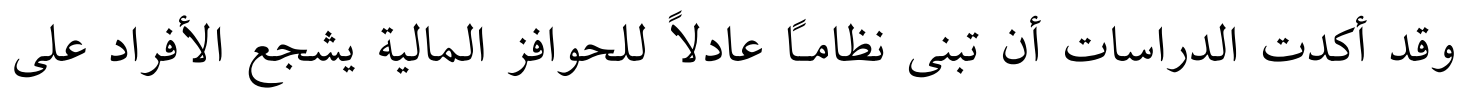
الالتحاق بالوظيفة العامة، ويدفعهم للأداء الجيد ويشجعهم ويرغبهم على الاستمرار بها، ويرفع مستوى الرضا الوظيفي لديهم، خصوصـا إذا كانت متو افقة مع ما يسطره الموظف كانف في ذهنه من طموحات وتوقعات ، فكلما كانت الحوافز المالية متماشية مع هذه الطموحات أو زادت عليها ارتفع مستوى الرضا الوظيفي لديه". ويتضح لنا أن العائد المالي يعد أهم العوامل المؤثرة في الرضا الوظيفي، ونظر اً لهذه الأهمية فقد أوليناه دراسة مستفيضة في المبحثين القادمين. ولو نظرنا إلى الشريعة الإسلامية، نجد أنها قد اهتمت منذ نعومة أظافرها بالمقابل المالي للموظف العام، نظراً لتأثيره على رضاه عن عمله، وانعكاس ذلك على له أدائه

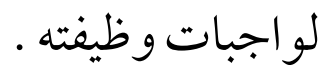

وقد ربط فقهاء الإسلام الرضا الوظيفي لحصول الموظف على مقابل مالي يسد خُلّته

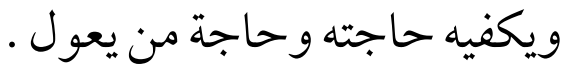

فقد ذكر (السرخسي ) أن الإمام يعطي القاضي كفايته من مال بيت المال ، وأنه لا بأس للقاضي أن يأخذ ذلك ، لأنه فرغ نفسه لعمل المسلمين ، فيكون كفايته وكفاية عياله في

(1) يراجع بتصرف وقريب من هذا المعنى : سامى صليحة : المناخ التنظيمي وتأثيره على الأداء الوظفي للعاملين

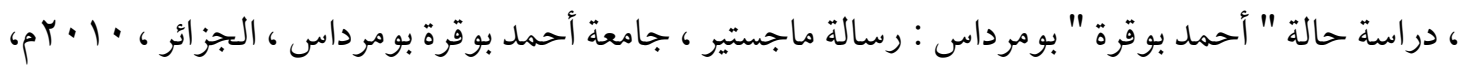

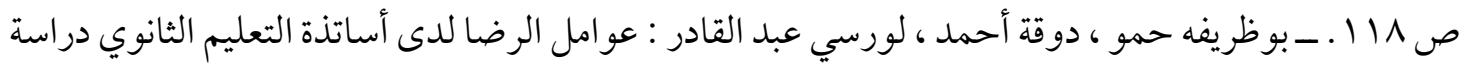

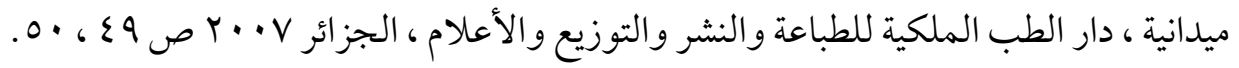


مال المسلمين (1).

ولم يقتصر الأمر على إعطاء القضاة فقط كفايتهم، وإنما امتد ذلك إلى غيرهم من الموظفين الذين فرغوا أنفسهم للقيام بو اجبات وظائفهم ، فقد قال السرخسي " إعطاء المقاتلة كفايتهم وكفاية عيالهم ، لأنهم فرغوا أنفسهم للجهاد ودفع شر المشركين عن المسلمين فيعطون الكفاية من اموالهم +. . . ومنه أرزاق القضاة والمفتين والمحتسبين و المعلمين وكل من فرغ نفسه لعمل من أعمال المسلمين "(r). وقد عبر فقهاء الإسلام في كتب التراث عن العائد المالي الذي يعود على القاضي خاصة وعلى الموظفين عامة بمصطلح " رزق القاضي " وهذا فيه دلالة قاطعة على أن الأجر عند تقديره يجب أن يكفيه وأهله حسب الزمان والمكان، كما ذكر ابن عابدين وحاشيته (r). (1) - n

فالتعبير بالرزق دليل الكفاية، والكفاية دليل على الرضا، فالرضا الوظيفي النابع من الرضا عن العائد المالي معتبر شرعًا عند فقهاء الإسلام ـ كما سنوضح تفصيلاً في المبحث القادم.

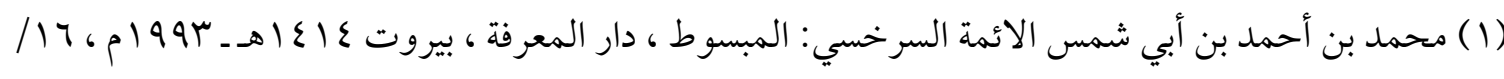
$.1 \cdot r$

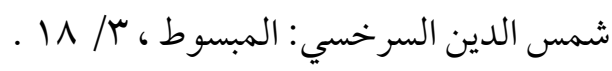

(r) محمد أمين بن عمر بن عبد العزيز بن عابدين : رد المحتار على الدر المختار للحصفكي شرح تنوير الابصار

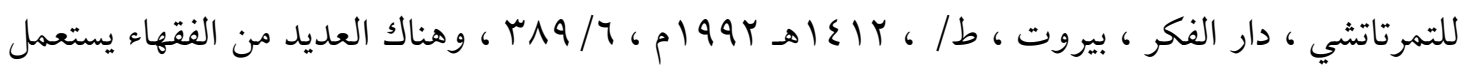
مصطلح رزق القاضي لإفادته للمعنى المذكور في المتن ، ومنهم : كمال الدين بن الهمام : فتح =القدير ، دار

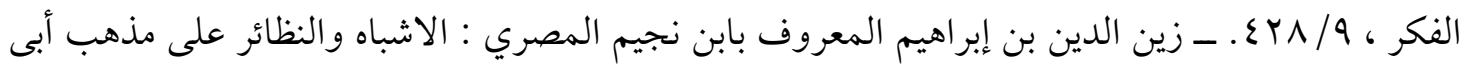

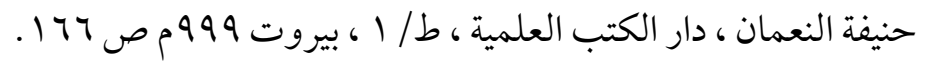


وقد برر الفقهاء ضرورة كفاية العائد المالي ، لكي لا ينشغل الموظف بتحصيل رزقه عن أداء واجبات وظيفته ، ولكي لا يطمع في أمو ال الناس وتمتد يده إلى الرشوة ، وهذا المبرر لو وضعته النظم الوضعية نصب عينيها عند تقدير رواتب الموظفين لقضينا على جانب كبير من الفساد الوظيفي · وفي ذلك يقول المارودي " وأما تقدير العطاء فمعتبر بالكفاية ، حتى يستغني بها عن التماس مادة تقطعه عن حماية البيضة "(1). وقال السرخسي في تبرير كفاية العائد المالي " فلابد له من الكفاية ، فإذا لم يرتزق احتاج إلى الرشوة"(r).

وتقدير العطاء بالكفاية لم يقتصر فقط عند بداية التحاق الموظف بعمله لمرة واحدة ، وإنما امتد النظر فيه بصفة دورية كل عام ، وروعي فيه ظروف المكان والزمان ومقدار الأعباء التي تثقل كاهل الموظف العام ، كما سنوضح ج · وفي ذلك يقول الألوسي " . فيقدر كفايته في نفقته وكسوته لعامه كله ، فيكون هذا المقدار في عطائه ، ثم تعرض حالة

$$
\text { في كل عام ، فإن زادت رواتبه ( أي حاجاته) الماسة زِيد "(r). }
$$

ويتضح لنا أن الشريعة الإسلامية قد وضعت رضاء الموظف عن عمله النابع من رضاه عن راتبه أو رزقه، موضع الاعتبار، وذلك لأهميته في الحد من الفساد الوظيفي

(1) أبو الحسن على بن محمد الشهير بالماوردى : الأحكام السلطانية والو لايات الدينية ، دار الحديث ، القاهرة ، مصر ، ص ه •r وفي نفس المعنى يراجع : القاضي ابو يعلى محمد بن الحسين بن الفراء : الأحكام السلطانية

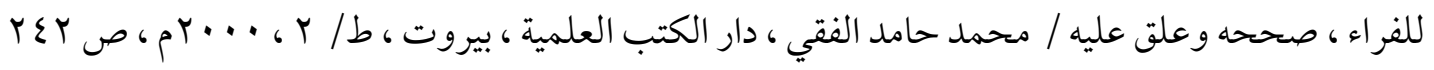

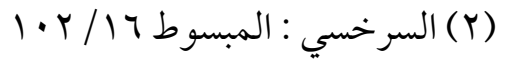

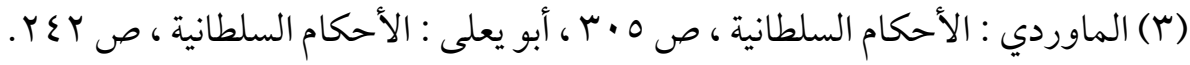


و لانعكاسه الإيجابي على أداء الموظف لو اجبات وظيفته .

ونخلص من كل ما سبق ذكره في هذا المطلب، أن هناك عو امل متعددة تسهم بشكل مباشر أو غير مباشر في تحديد درجة الرضا ومداه بالنسبة للموظفين، منها ما يتعلق بتنظيم ممارسة الوظيفة، ومنها ما يتعلق بالوظيفة ذاتها، ومنها ما يتعلق بقدرات وامكانيات الموظف الشخصية، وبسبب كثرة وتعدد هذه العوامل، فإنه يصعب تحقيق الرضا الوظيفي الكامل للموظفين، لأنه من الصعوبة بمكان توافر كل هذه العوامل مجتمعه بدرجة واحدة، لذا يظل الرضا الوظيفي حالة نسبية يختلف من موظف لآخر ومن وظيفة لأخرى

غير أنه يمكن لنا القول بأنه يوجد قدر كبيرة من الرضا الوظيفي يشترك فيه جُل الموظفين - إن لم يكن جميعهم ـ نابع هذا القدر من رضاهم عن العائد المالي الذي يعود عليهم من عملهم، وهذا القدر اتفقت عليه كل من النظم الوضعية والشريعة الإسلامية، وهو الذي جعلنا نهتم بالأجور الحافزة في المبحث القادم

والسؤال الذي يطرح نفسه على بساط البحث الآن هو، إذا كان الرضا الوظيفي بهذه الأهمية، فكيف يمكن قياسه ؟ خاصة في ظل أنه نسبى يختلف من موظف لآخر ومن وظيفة لأخرى ؟ وهذا ما نجيب عليه في المطلب التالي:

\section{المطلب الرابع}

\section{أساليب قياس الرضا الوظيفي ومظاهر تحقيقه}

سبق لنا القول بأن الرضا الوظيفي هو عبارة عن مشاعر داخلية لدى الموظف العام ،

و أن هذه المشاعر في الحقيقة يصعب ، بل يستحيل قياسها مادامت حبيسة النفس ، غير أن هذه المشاعر يمكن الاستدلال على وجودها وتحديد نوعها ودرجتها من خلال سلوك 
الموظف الخارجي الذي يعكس بصورة إيجابية أو سلبية عما بداخله من مشاعر ، وهذا

يمكن أن يطلق عليه مظاهر تحقق الرضا الوظيفي وهي التي تكشف عن وجوده •

وتوجد عدة مظاهر تدل على وجود الرضا الوظيفي نذكر منها"):

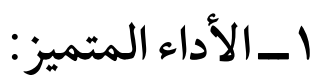

إن أداء الموظف العام لو اجبات وظيفته بكفاءة عالية وجودة مرتفعة وبإتقان، يعكس

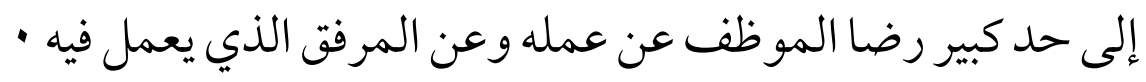

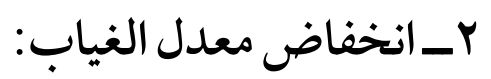

انتظام الموظف في عمله وعدم تغيبه أو تأخره عن مواعيد العمل الرسمية، يمكن أن

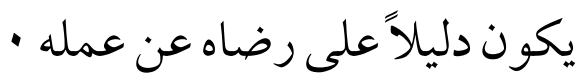

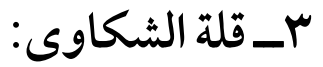

إن الشكاوى المتكررة وكثرة التظلمات، سواء كانت فردية أو جماعية تدل على عدم الرضا الوظيفي، والعكس صحيح، فإن قلتها أو انعدامها لهو دليل على رضاء الموظف

• العام ونجاحه في أداء أعمال وظيفته

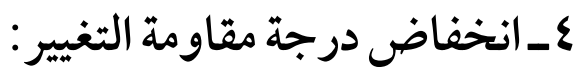

تحتاج الوظيفة العامة إلى تطوير مستمر ليو اكب مستجدات العصر والتطور، خاصة في أسلوب الأداء وإجراءات الانضباط، وهي مسئولية الرؤساء في المقام الأول، فعندما يعمل القادة على التغيير والتطوير وتوجد استجابة من قبل الموظفين، ولم يكن هناك

(1) يراجع في ذلك ليندى بن سهل : الحوافز وعلاقتها بالرضا الوظيفي دراسة ميدانية مطبقة على عينة من أعوان

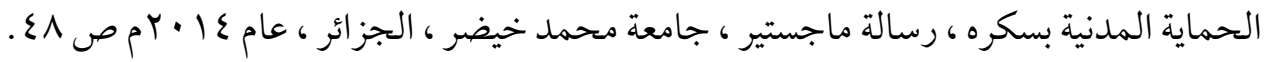


مقاومة لهذا التغيير، يعد ذلك دليل على الرضا الوظيفي ·

فمظاهر الرضا الوظيفي متعددة (1)، وهذه المظاهر هي التي توصلنا إلى مدى وجود الرضا الوظيفي ودرجته، وذلك من خلال قياس الرضا الوظيفي، والسؤال الآن، كيف

$$
\text { يقاس الرضا الوظيفي انطلاقًَا من مظاهره؟ }
$$

في البداية يقصد بقياس الرضا الوظيفي، عملية جمع البيانات الدالة على مستوى رضا جماعة العمل الموجودة في المنظمة عن عناصر الرضا المختلفة("). ومن الأمور التي يجب الاهتمام بها داخل الوظيفة العامة التعرف على درجة الرضا الوظيفي لدى الموظفين، ويجب أن تتم هذه العملية من وقت لآخر لرصد التغيير الذي يطر أعلى درجات الرضا الوظيفي لدى الموظفين من وقت لآخر (r). وعملية القياس هذه تعد الخطوة الأولى في دراسات الرضا الوظيفي، ولكي تكون حقيقية يجب أن تمر بعدة إجراءات وترتيبات خاصة تكفل إمداد الإدارة بمعلو مات وقتية وحقيقية حول شعور الموظفين تجاه أعمالهم والظروف السائدة في أروقة العمل داخل منظماتهم وعلى الرغم من وجود وسائل مختلفة لقياس الرضا الوظيفي، إلا أن عملية القياس

(1) من مظاهر الرضا انخفاض معدل دوران العمل، والتمارض واختفاء الشائعات التي تؤثر على سير العمل وأداء الموظف العام لو اجبات وظيفته، ومن المظاهر ايضًا عدم كثرة الإجازات بدون مرتب، للعمل في القطاع الخاص أو للعمل خارج البلاد لتحسين الدخل، كل هذا يرفع درجة الرضا الوظيفي، والعكس بالعكس، كثرته دليل على عدم الرضا وانخفاض درجته .

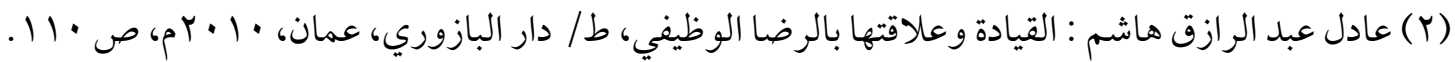
(Y) قريب من المعنى: محسن على الكتبى : السلوك التنظيمي بين النظرية والتطبيق ، ص VIV. 


\section{تهدف إلى تحقيق ثلاثة أهداف رئيسية):}

الأول: يتضمن تحديد مستويات رضا أفر اد التنيم ومعرفة معيار الرضا أو عدمه. الثاني: معرفة مدى اختلاف مستويات الرضا الوظيفي ومحدداته ومؤشراته بين جماعات وأقسام العمل المختلفة داخل المؤسسة. أما الهدف الثالث الذي ترمى إليه عملية القياس ، فهو دراسة العلاقة بين مستوى الرضا

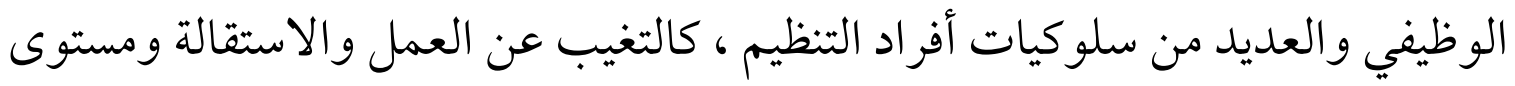

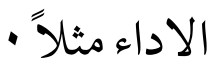

وفي الحقيقة لا توجد طريقة واحدة لقياس الرضا الوظيفي(()، لأن الرضا شعور وأحاسيس وهي تختلف من موظف لآخر، ولوجود عدة متغيرات تتحكم في هذه

(1) عادل عبد الرازق هاشم : القيادة وعلاقتها بالرضا الوظيفي، صـ 11. (Y) حصر البعض أساليب القياس في نوعين : الأول : أساليب موضوعية، ويمكن من خلالها قياس اتجاهات العاملين ورضاهم عن طريق استخدام أساليب قياس معينة تقيس الآثار السلوكية لهم مثل معدل الغياب ، وترك الوظيفة ، ومعدل الحو ادث في العمل ، و كذلك معدل الشكاوى ، ومستوى الانتاج ، وهذا المعيار يفيد في التنبه بمشكلات الموظفين الخاصة برضاهم ، لكن لا تتوافر في الغالب بيانات تفصيلية لمعرفة أسباب المشكلات أو علاجها • النوع الآخر : المقاييس الذاتية للرضا الوظيفي ، ويقيس هذا النوع الرضا مباشرة ،

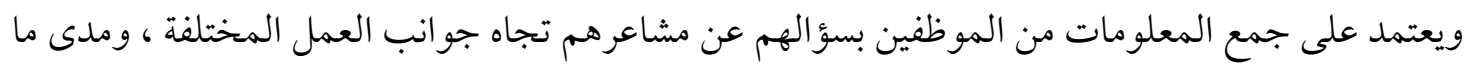

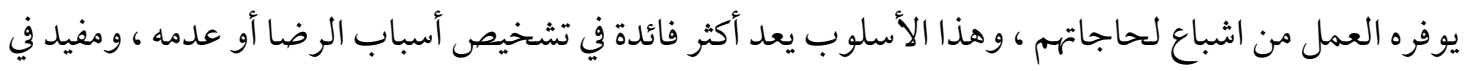
اقتراح جوانب التغيير المطلوب في البرامج التي تؤثر على متغيرات الرضا، ومن الوسائل المستعملة في هذا

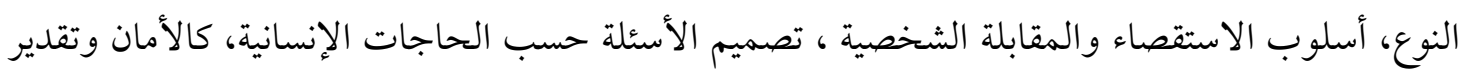
الذات أو الحو افز، كالأجر وفرص الترقي، راجع في ذلك صلاح محمد عبد الله : السلوك التنظيمي ـ مدخل

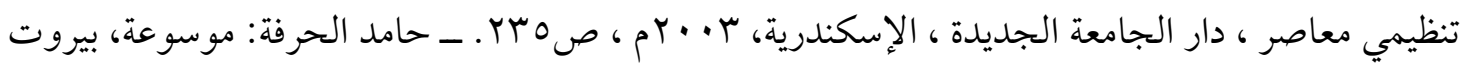


المشاعر لدى الموظفين، مما أدى إلى ظهور عدة طرق لقياس الرضا الوظيفي ، نذكر

منها:

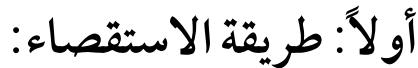

تعتمد هذه الطريقة على استطلاع آراء الموظفين في المرفق العام الذي يعملون فيه وفق نموذج معين يتم تصميمه بشكل يتلاءم مع طبيعة الوظيفة والهدف من الاستقصاء، بحيث تتضمن عوامل الرضا المراد التأكد من وجودها وتأثيرها على الرضا، ومن النماذج التي تفيد في هذه الطريقة نموذج ( بورتو ) الذي يستهدف قياس رضا الفرد عن وظيفته في ضوء إشباعها لخمس فئات من الحاجات الإنسانية هي الحاجة إلى الأمن، الحاجة إلى الانتساب، الحاجة إلى تقدير الذات، الحاجة إلى الاستقلال، الحاجة إلى تحقيق الذات، ومن مزايا هذه الطريقة سهولة تصنيف البيانات كميـًا، وامكانية استخدامها في حالة كثرة الموظفين، كما تمتاز بقلة تكلفتها")

\section{ثانيا: طريقة التدرج التجميعي (ليكرت) :}

ووفقًا لهذه الطريقة يتكون القياس من مجموعة من العبارات التي تشير إلى الخصائص الإيجابية للعمل، وتتبع كل عبارة منها بخمسة آراء متراوحة بين الموافقة القوية والمعارضة الشديدة، ويطلب من كل موظف تقييم كل عبارة منها باختيار واحدة من درجة موافقته عليها ( أوافق بشدة ، أوافق ، محايد ، لا أو افق ، لا أوافق بشدة )(r)، ثم

(1) سالم تيسير الشرايده : الرضا الوظيفي أطر نظرية وتطبيقات عملية، دار الصفا للنشر والتوزيع ، طا، عمان

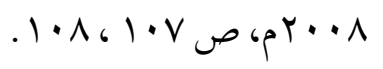

(Y) العبودي فاتح : الضغط النفسي وعلاقته بالرضا الوظيفي ، رسالة ماجستير ، جامعة منتوري، قسنطينه، الجزائر

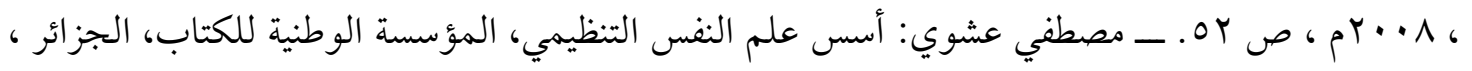

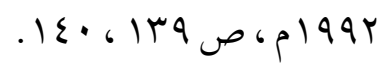


يتم تجميع الدرجات التي حصل عليها الفرد من تقييمه للعبار ات، ومن خلال هذه النتيجة نستطيع تقييم القيمة الكلية لرضاه

وتمتاز هذه الطريقة بأنها لا تحتاج إلى خبراء أو حكام، بل يمكن أن يتم إجراؤها

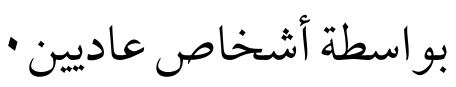
ثالثًا: طريقة تحليل ظواهر الرضا:

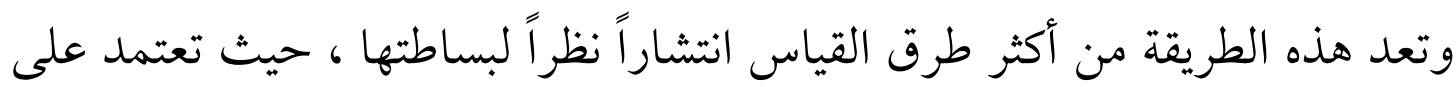
تحليل عدد من الظواهر المعبرة عن درجة رضا الموظف ومشاعره تجاه عمله، (1) ومن

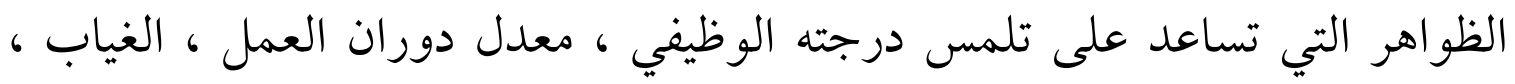
التمارض ،معدل الشكاوى، انخفاض الأداءء). فقد أظهر تحليل هذه الظواهر أن الموظفين الذين لديهم درجة عالية من الرضا الوظيفي جاءت معدلات تحليل هذه الظواهر منخفضة ، أي أن هناك علاقة عكسية بين ممارستهم لهذه الظواهر وبين الرضا الوظيفي ، كما ارتفع ممارستهم لهذه الظواهر

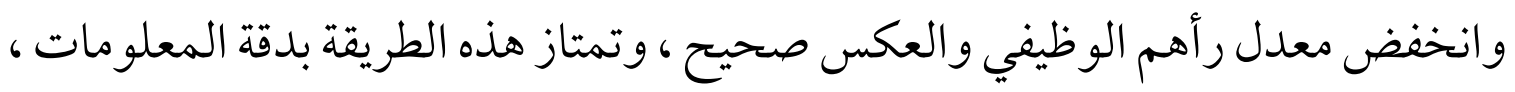
وسهولة تصنيفها ، والابتعاد عن التحيز بكون هذه الظو اهر يتم رصدها بسهولة ولكونها

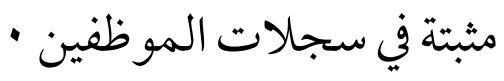
رابعًا : طريقة الوقائع الحرجة ( هارز بربغ ) :

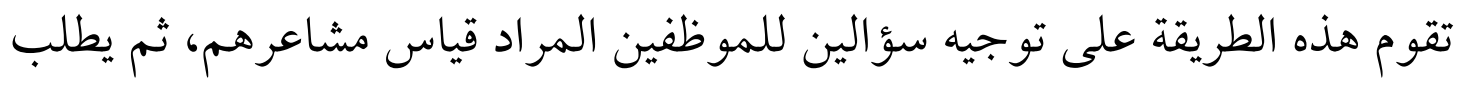

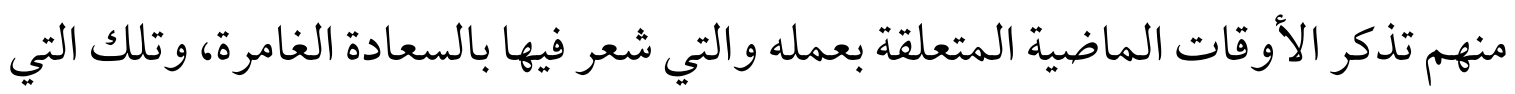

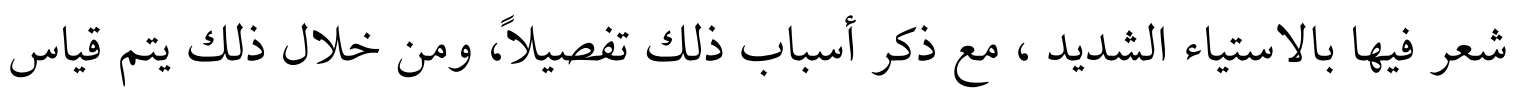

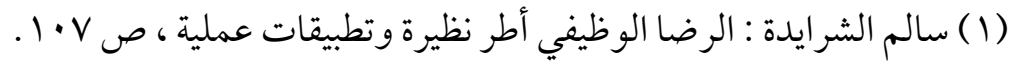

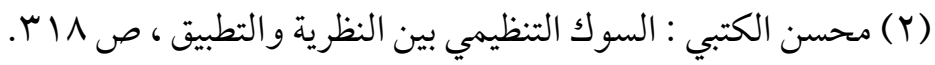


الرضا الوظيفي ودرجته، غير أن الحصول على معلومات أوفر عن الوقائع المسببة للسعادة وتلك المسببة للاستياء يقتضى توسيع دائرة الاسئلة لتشمل أكثر من واقعة حسب ما يدلى به الموظف الخاضع للقياس (1). خامسـا: طريقة ثير ستون :

يبنى هذا المقياس باستعمال عبار ات عادة تفوق المائة عبارة لوصف مختلف العناصر التي تمس الرضا، ثم يطلب من الموظفين الخاضعين للقياس الإجابة عنها بنعم أو لا، ثم يتم تقييم هذه العبارات بمعرفة المصمم أو الحكم، بناءً عليه يتم قياس مستوى الرضا الوظيفي، ويمكن تجميع العبار ات التي تتعلق بمجال معين أو خاصية معينة مثل، الأجر، محتوى العمل، الاشراف، وحساب درجة الرضا عن هذا المجال على حدى، وثم التعرف على درجة الرضا(). من خلال العرض السابق يتضح لنا أن هناك عدة طرق يتم قياس الرضا الوظيفي من خلالها(r)، وقد استخدم العلماء أدوات مختلفة وعملوا على تنميتها لقياس الرضا

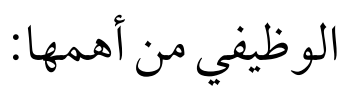

(1) سالم الشرايدة : الرضا الوظيفي أطر نظرية وتطبيقات عملية ، ص V•l ــ ـ العبودي فاتح : الضغط النفسي وعلاقته بالرضا الوظيفي، ص مه م.

(Y) رشيد زرواتي : تدريبات على منهجية البحث العلمي في العلوم الاجتماعية ، دار هومة للنشر، الجزائر ،

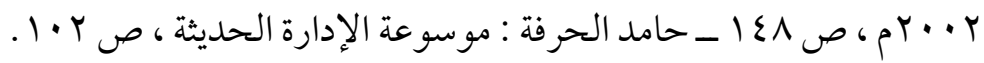
(r) هناك بعض الطرق الأخرى لقياس الرضا الوظيفي ، منها طريقة أسكود، وتتكون من مجموعة من المقاييس الجزئية لكل جانب من جو انب العمل ، بحيث يحتوى كل مقياس على قطبين يمثلان صفتين متعارضتين بينهما

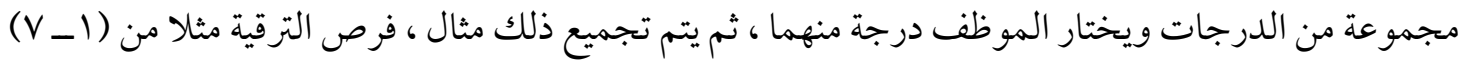
الرقم V يرمز إلى كونها عادلة والرقم واحد (1) غير عادلة ويختاز الموظف من بينهن، راجع أحمد صقر عاشور: إدارة القوى العاملة الأسس السلوكية وأدوات البحث التطبيقي، دار النهضة، بيروت، بـ919 ام ص •جـ. 
1ـ الاستبانات ذات المقاييس المقننة : وتعد من أشهر المداخل لقياس الرضا الوظيفي، ويمتاز هذا النوع من الاستبانات بأنه يمكن استيفاؤه بسرعة وبدرجة عالية من الكفاءة ، كما أن تطبيق المقياس على درجة كبيرة من الموظفين في مجالات مختلفة

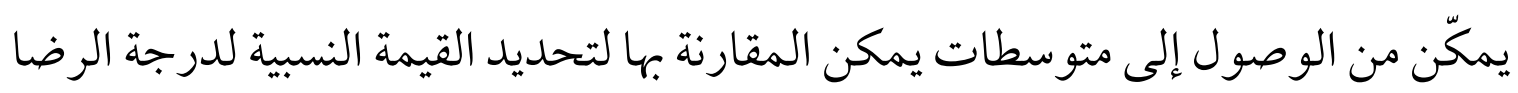
عن العمل في المنظمة، وهناك نوعيات عديدة من هذه الاستبانات منها مقياس أو استبانة وصف المهنة JOB DeSCRIPTION INDEX (JDI) وهذا المقياس يتعامل مع خمسة مفاهيم للعمل وهي : العمل نفسه، الأجر، فرص الترقية، الإشراف، الزملاء، ويضم كل بعد من الأبعاد الخمسة قائمة من الكلمات أو الجمل القصيرة ، وعلى الموظف أن يحدد ما إذا كانت كل كلمة أو جملة تصف شعوره تجاه وظيفته أم لا، باستخدام إجابات ثابتة نسبيًا، ولكل جملة أو كلمة قيمة رقمية توضح مستويات الرضا الوظيفي، وفي النهاية يعطينا جمع تقديرات هذه الإجابات درجة الرضا عن كل بعد، ويمكن تجميع القيم الرقمية للأبعاد الخمسة لتعطينا عادة قيمة رقمية لمستوى الرضا الوظيفي العام ، كما أنه يوجد مقياس شائع الاستخدام وهو مقياس أو استبانة مينيسوتا، وفي هذا المقياس يعبر الموظف عن مدى رضاه عن بعض النواحي المتعلقة بالعمل، مثل الأجر وفرص الترقي، ظروف

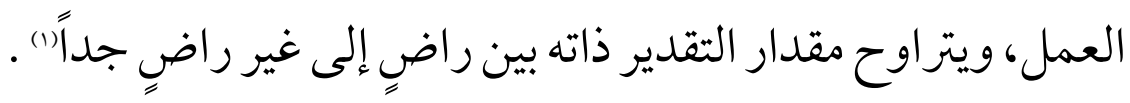

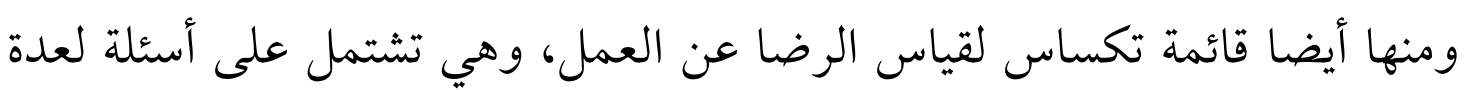

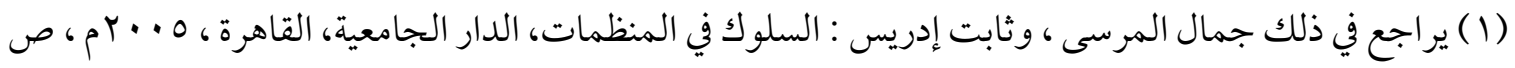

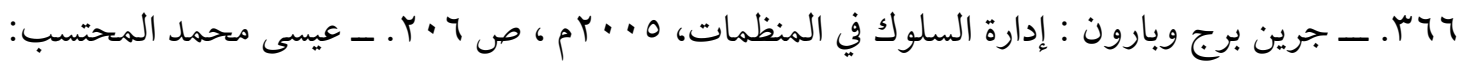

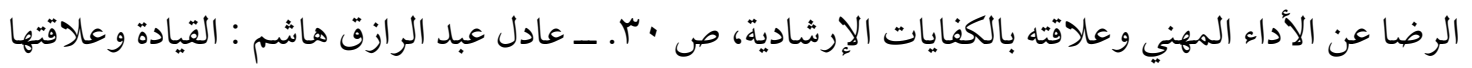

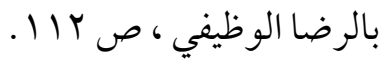


عوامل، مثل ظروف العمل، الترقية، الأجور، مناسبة العمل لقدرات ومؤهلات الموظف، حركة التغيير، اتجاهات الإدارة • الخ").

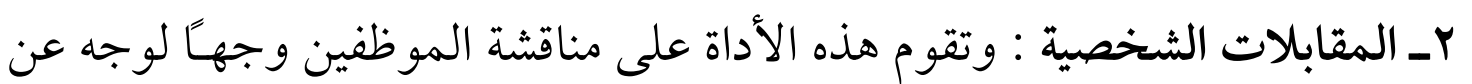
طريق طرح الأسئلة وتلقى إجاباتهم عليها مباشرة وتحليل هذه الإجابات، وبناءً على ذلك يمكن معرفة مدى رضا الموظفين من عدمه، وأي عناصر العمل ينظر إليها برضا تام، وأي العناصر ينظر إليها برضا أقل ،(1) وكلما كانت المقابلة في بيئة يشعر فيها الموظفون بـ بالأمان وبحرية في اجاباتهم، وأن إجاباتهم صادقة، كلما كانت ننيجة المقابلة معبرةً تعبيراً صحيحكاعن قياس الرضا الوظيفي

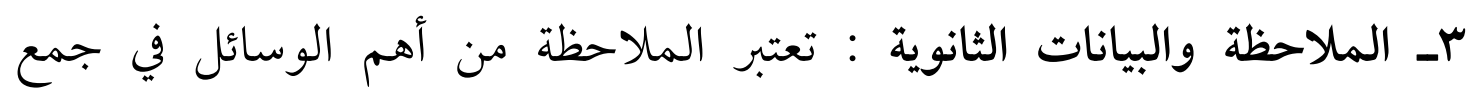
المعلومات، فمن خلال متابعة سلوك الموظفين يمكن استخلاص معرفة شعورهم تجاه أعمال وظائفهم، ومن ثم قياس رضاهم،"(r) كما أنه يمكن استنتاج مدى رضاء الموظفين من خلال بياناتهم الثانوية المتاحة في مقر عملهم، كمعدلات غيابهم، نسبة الإنتاج، الشكاوى، فمن خلال تحليل هذه المؤشرات يمكن قياس رضاهم الوظيفي •

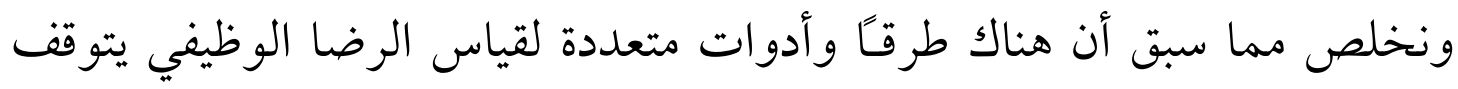
الأخذ بإحداها على جملة من العوامل منها، طبيعة المعلومات التي ير اد الحصول عليها، من حيث اتصافها بالدقة والموضوعية، التكلفة المادية و الزمنية، حجم الوحدة التي يراد قياس رضا الموظفين فيها، إلى غير ذلك من العوامل التي يتحدد على أساسها اختيار

\footnotetext{
(1) عادل عبد الرازق هاشم : القيادة وعلاقتها بالرضا الوظيفي، ص. ـ 11.

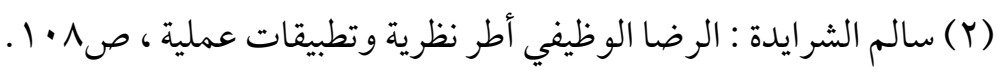

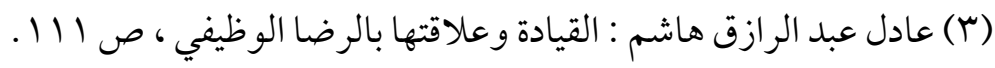


الطريقة المناسبة لقياس الرضا الوظيفي ·

ولو نظرنا إلى الشريعة الإسلامية نجد أنها قد عرفت قياس الرضا الوظيفي عن طريق الملاحظة والمتابعة من قبل القادة الإداريين لمرؤوسيهم، وذلك من خلال الرقابة

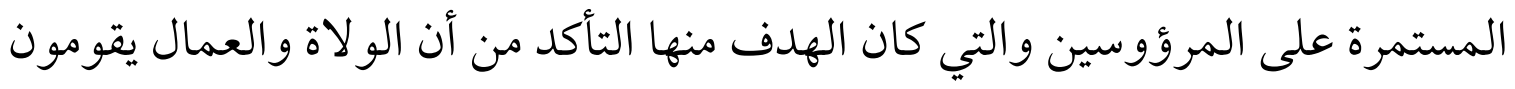

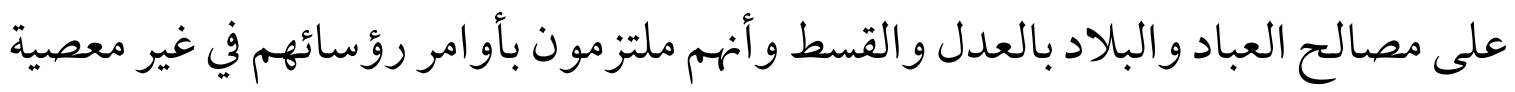
الله وبما يحقق المصلحة العامة، هذا من ناحية، ومن ناحية أخرى التأكد من رضا الولاة عن أعمالهم. وقد حرص الخلفاء الراشدون على متابعة ولاتهم على الأقاليم بأنفسهم ليتفقدوا

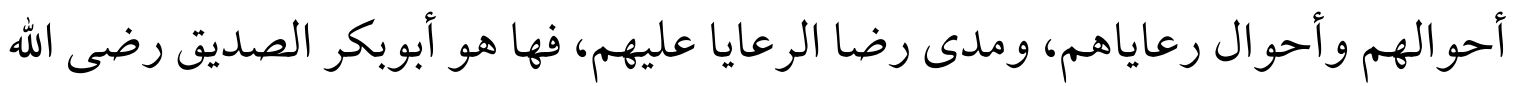

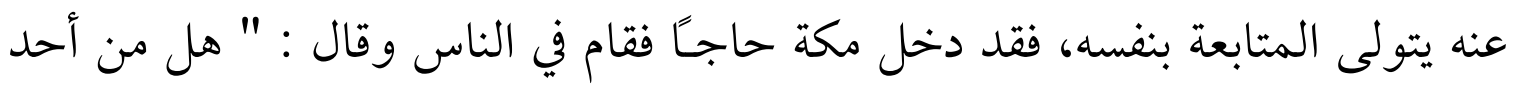

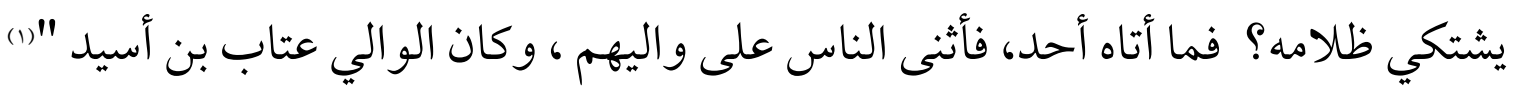

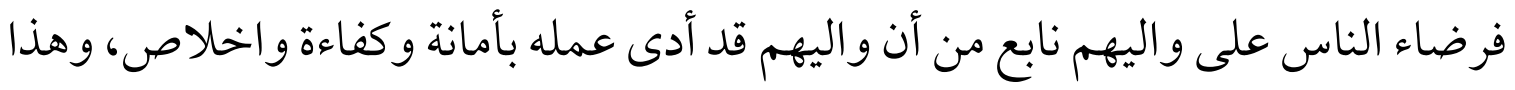

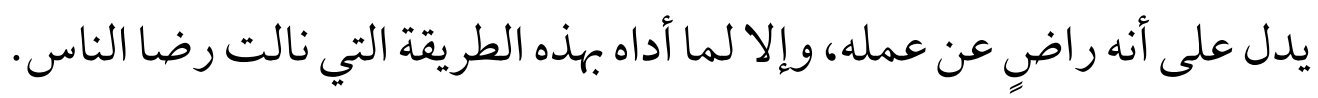

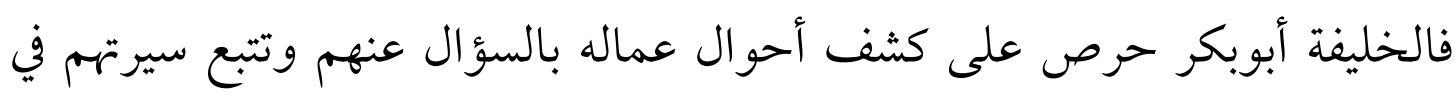
الناس، على الرغم من أنه كان كصاحبه ـ صلى اله عليه وسلم ـ يختار أكثرهم علمًا وعملاًاً) وقد مارس الفاروق عمر رضى الله عنه هذه المتابعة والملاحظة للوقوف على أحوال

(1) ظافر القاسمي : نظام الحكم في الشريعة والتاريخ الإسلامي، دار النفائس ، بيروت، الكتاب الأول الحياة

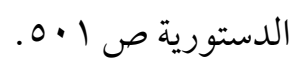

(Y) محمد كردعلي : الاسلام والحضارة العربية، / 1 •1. 
عماله، و كان علمه بمن نأي عنه من رعيته كعلمه بمن بات معه في مهاد و احد وعلى وساد واحد، فلم يكن له في قطر من الأقطار ولا ناحية من النواحي عامل ولا أمير جيش، إلا وعليه له عين لا يفارقه ما وجده، فكانت ألفاظ من بالمشرق و المغرب عنده في كل ممس ومصبح ولقد بلغت المتابعة في عهد سيدنا عمر أعلى درجاتها، وكان رضى الله عنه أول من أنشأ نظام التفتيش في الإسلام، وهو من ابتكار اته التي دعت إليها الحاجة، وسار الحكم الإسلامي من بعده على سنته، فلم تخل حكومة إسلامية على مدى العصور من صاحب

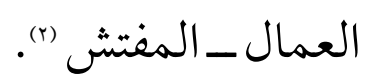

وقد أرسل خامس الخلفاء الراشدين المراقبين والثقاة، أمثال بشر بن صفوان، وعبد الله بن عجلان، وخالد بن سالم إلى خرسان حينما اشتكى الناس من نظام الخراج الذي فرضه واليهم عدى بن أرطأه ، كما أرسل الثقاة أيضا لتصفح أحوال الناس في الأمصار، وفي خطاب التكليف بالمهمة التي أسندها إلى رياح بن عبيدة، ليأتيه بأخبار الناس والو لاة ـ عمال الأقاليم ـ في العراق قال ـ خامس الخلفاء الراشدين ـ : " حاجتي إليك أن تسأل عن أهل العراق، وكيف سيرة الو لاة فيهم ورضاهم عنهم" "(r). ويتضح مما سبق أن قياس الرضا الوظيفي لم يكن بالأمر الغريب على الإدارة في صدر

$$
\text { (1) محمد كرد علي : المرجع السابق ص 11111. (11) }
$$

(Y) ظافر القاسمي : نظام الحكم في الشريعة والتاريخ الإسلامي ، الحياة الدستورية ، ص ع ع.0، ـ أبوعبد الله محمد بن عبدوس الجهشياري : الوزراء والكتاب، حققه ، مصطفي السقا، إبراهيم الإبياري، عبد الحفيظ

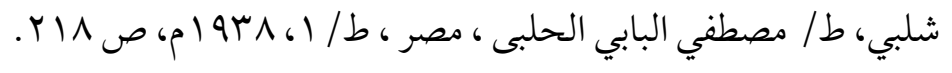

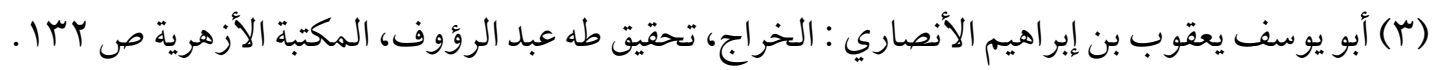


الإسلام ، وهذا يؤكد لنا أن الشريعة الإسلامية لم تترك أمراً فيه صلاح الناس إلا وعرفته وأقامت عليه وأقرته، ومن ثم فهناك اتفاق بين النظم الوضعية والشريعة الإسلامية فيما يتعلق بقياس الرضا الوظيفي، غير أن النظم الوضعية قد أوجدت طرقكً جديدة لقياس الرضا الوظيفي لم تكن معروفة في الإدارة الإسلامية القديمة ، إلا أن الشريعة الإسلامية

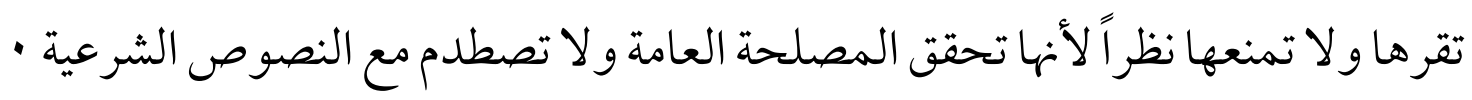
وبذلك ينتهي الحديث عن الرضا الوظيفي، ونتتقل على أهم العوامل المؤثرة في الرضا الوظيفي وهو العائد المادي من الوظيفة والذي أطلقنا عليه الأجور الحافزة . 


\section{المبحث الناني \\ النظام القانوذي للأجور الحافزة}

تمهيد وتقسيم :-

سـبق القـول بـأن العائـد المـادي يمثـل أهــم عو امـل الالتحــاق بالوظيفـة العامـة في وقتنـا الحسالي، ولـه دور كبيـر في تحقيـق رضـاهم الـوظيفي، ومسن ثـم تشـيعهم على الاهتمـام بأعمـالهم الوظيفيـة، و التفـــ التـام للقيـام بهـا على أكمـل وجـه، سـواء كـان في النظـام الإداري الوضــعي أو الإســلامي، فيجــبـ علــى جهـــة الإدارة أن تهــتم

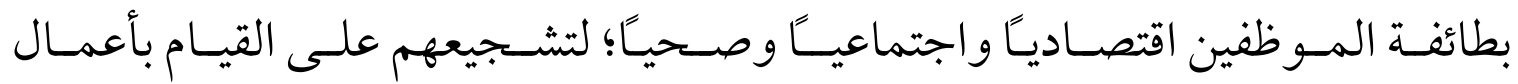

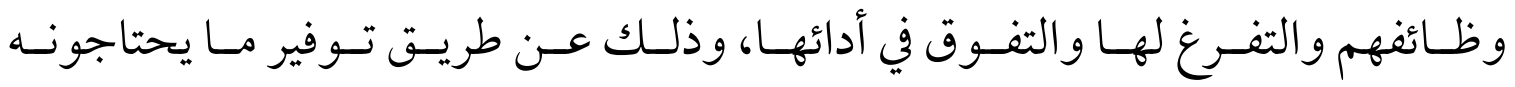

$$
\text { ليحيو ا حياة كريمة هم ومن يعولوا. }
$$

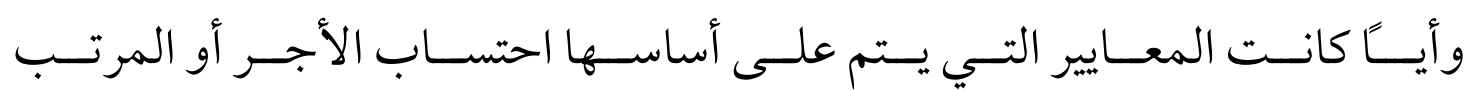

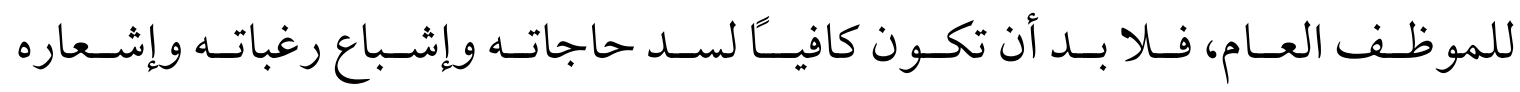
بالرضا، لكي يتفرغ لأداء عمله بالإتقان المطلوب.

ومــن هنـا نسـتطيع أن نقــول إذا وصــل العـادي المـادي إلـى إشــعاره بالرضــا الـوظيفي، يمكـن لنـا أن نصـفه الأجــر الحــافز، فـالأجور الحــافزة هـي التـي تصـل

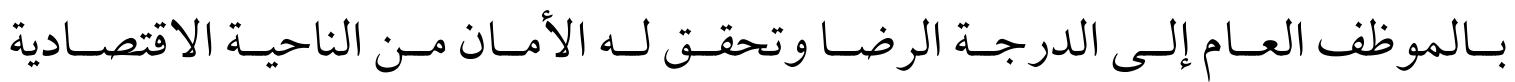
والاجتماعية و الصحية.

لـذلك لا تقتصـر الأجـور الحـافزة علسى المبلــن المـالي الـذي يتقاضـاه الموظـف بشـكل دوري كـل شـهر، و إنمـا تمتــ لتشـمل كـل مـا يعـود على الموظـف العـام مـن مزيا لقاء عمله، سواء كانت مزايا نقدية أو عينية أو خدمية. 
و إذا كانـت الـنظم الوضـعية قـد حاولـت تحقيـق كفايـة الموظـف العـام مسن خـلال

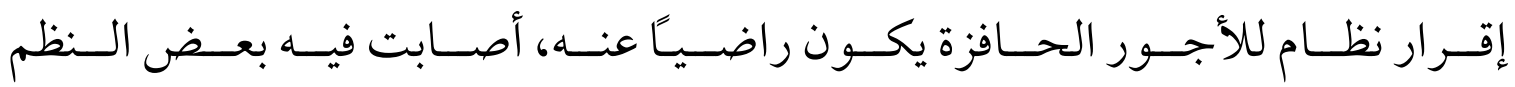
و أخطـأت، فــإن الشـريعة الإسـلامية قــد وضـعت نظريسة متكاملـة لتحقيـق رضــاء الموظف العام النابع من توفير كل ما يحتاجه هو ومن يعول ليحيوا حياة كريمة.

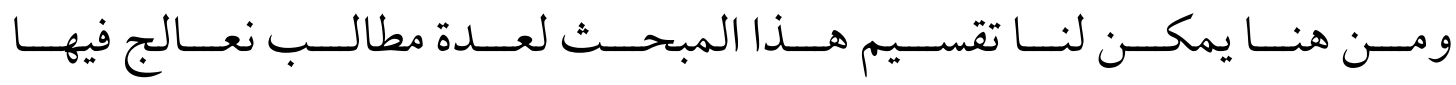
الموضوعات التالية في النظم الوضعية والشريعة الإسلامية. المطلب الأول: مفهوم الأجور الحافزة وأهميتها. المطلب الثاني: مشتملات الأجور الحافزة. المطلب الثالث: أسس وطرق تقدير الأجور الحافزة.

\section{المطلب الأول}

\section{مغهومر الأجور الحسافزة وأهميتهـا}

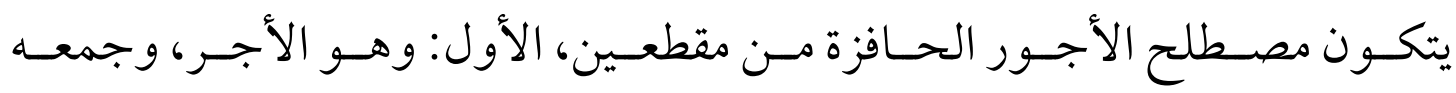

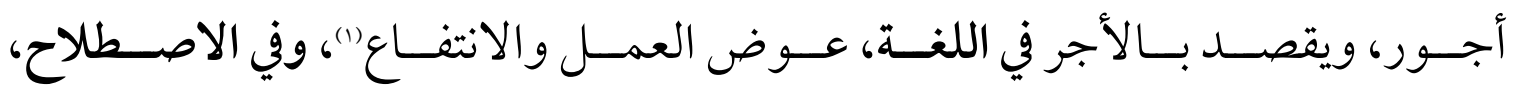

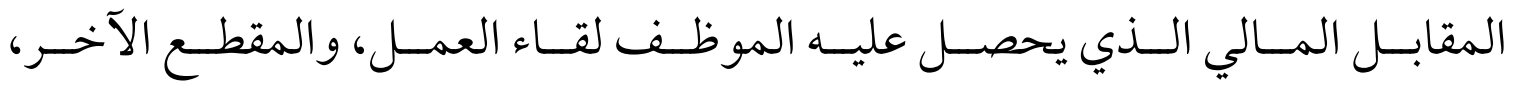

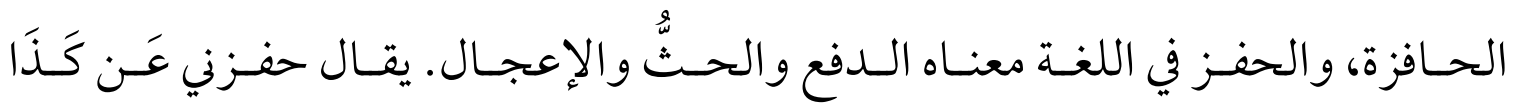
وَكَذَا يحفزني حفزاً أَي أعجلني، ودفعني وحثني على القيام بالعمل (r).

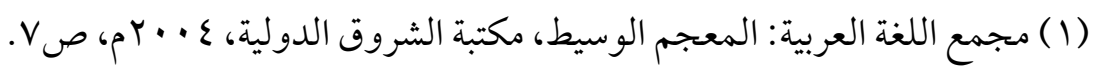

(Y) يراجع في المعني اللغوي لمادة حفز، أبو بكر محمد بن الحسن بن دريد الأزدي: جمهرة اللغة، المحقق: رمزي

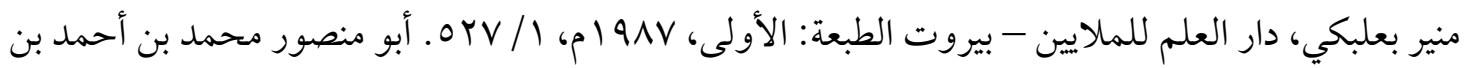
الأزهري الهروي: تهذيب اللغة، المحقق: محمد عوض مرعب، دار إحياء التراث العربي - بيروت الطبعة:

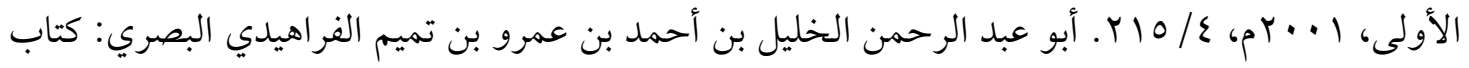


إذاً فـالأجور الحسافزة، هـي كـل مـا يعسود علسى الموظـف العـام مـن مزايـا لقــاء

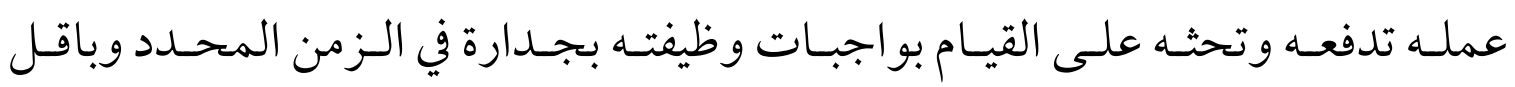
تكلفة.

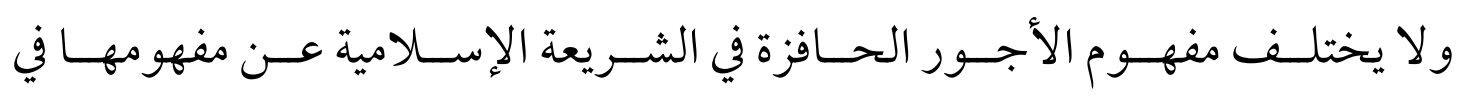

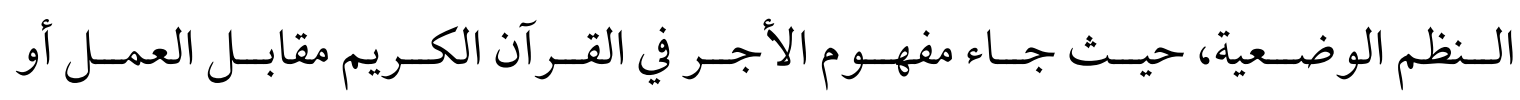

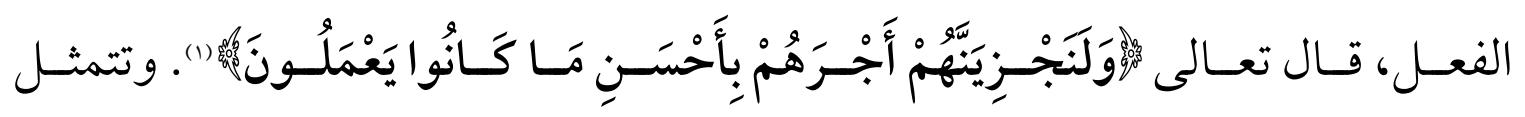

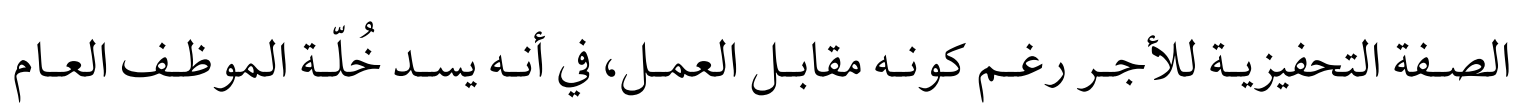
ويشبع رغبته ليحيا حياة كريمة. والأجور الحافزة في الإسلام، هي المبالغ النقدية أو العطايا العينية والمزايا التي تعطى للموظفين مقابل عملهم لإثارة الرغبة لديهم وتحفيزهم على القيام بواجبات

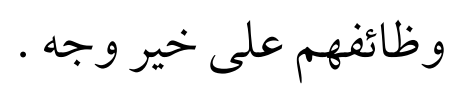

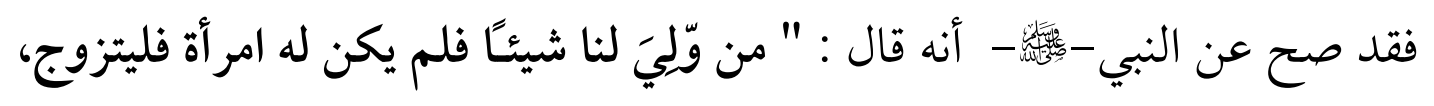
ومن لم يكن له مسكن فليتخذ مسكنًا، ومن لم يكن له مركب فليتخذ مر كبًا، ومن لم

العين، المحقق: د مهدي المخزومي، د إبراهيم السامر ائي، دار ومكتبة الهلال، ؟/ ع 1 ا ـ أبو نصر إسماعيل بن

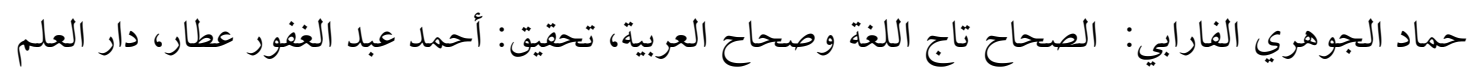

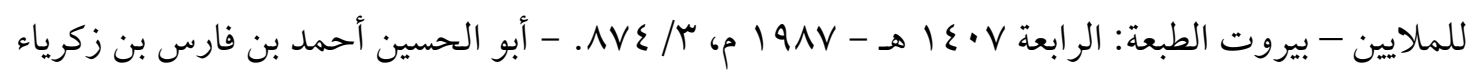

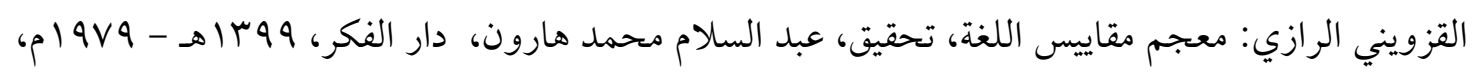

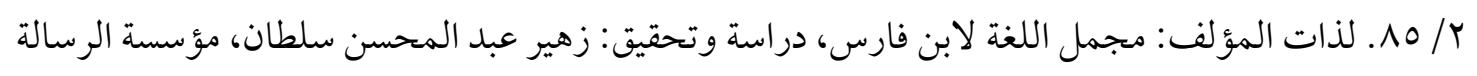

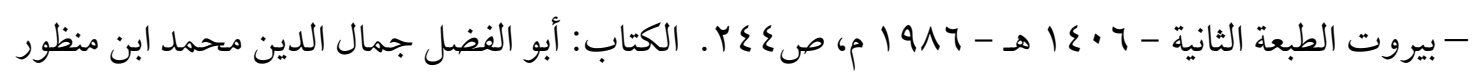

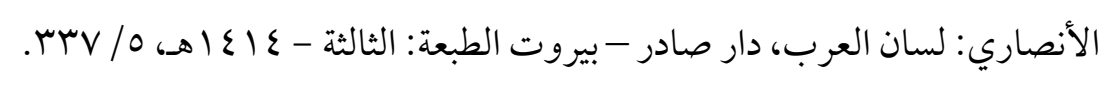

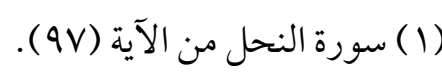


يكن له خادم فليتخذ خادمًا، فمن أعدّ سوى ذلك جاء يوم القيامة غالاً سارقًَ "(1). فالأجور الحافزة تعمل على إثارة الرغبة في العمل لدى الموظفين، وذلك عن طريق التعرف على احتياجات الأفراد ورغباتهم لتقديم الأجور التي تشبع هذه الاحتياجات وتدفع القوى الكامنة لديهم للمساهمة عن رغبة واقتناع منهم بتمية قدراتهم ورفع مستوى أدائهم لواجبات وظائفهم، وهذا ما لمسه المصطفى صلى اله عليه وسلم في

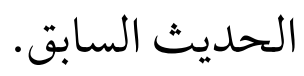
أهمية الأجور الحافزة: وتمثل لأجور الحافزة ـ سواء كان في الشريعة أو القانون ـ أهمية كبيرة للأفر اد ولجهة الإدارة وللمجتمع على السواء. 1 - فبالنسبة للأفراد، تمثل الأجور الحافزة الدافع الأول - إن لم يكن الأوحد- الذي يجعل الأفراد يتسابقون ويتهافتون على طلب الوظيفة العامة في الآونة الأخيرة بسبب الظروف الاقتصادية السيئة التي تمر بها البلاد، لضمان حياة -لا أقول كريمة- وإنما متوسطة الحال لهم و لأسرهم. وتعد المصدر الأساسي لمعيشتهم، والمحدد الرئيسي لرفاهيتهم وإشباع حاجاتهم، كما تؤثر أيضًا على مكانة الفرد الاجتماعية في المجتمع، حيث تقاس منزلة الفرد في بعض المجتمعات بما يحققه من دخل مالي، كما تدفع الأجور الحافزة الفرد لمزيد من

(1) ابن خزيمة : صحيح بن خزيمة ، باب إذن الإمام للموظف بالتزويج واتخاذ الخادم والمسكن من الصدقة ،

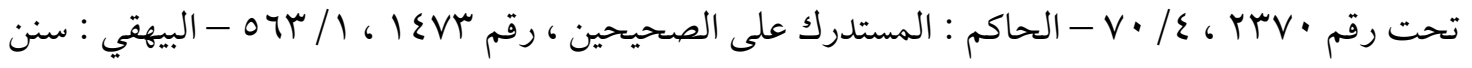

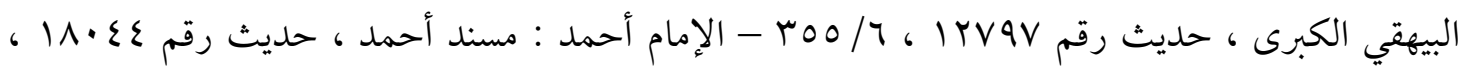


الترقي وتنمية القدرات للقيام بواجبات وظيفته على خير وجه..(1) وفي الشريعة الإسلامية تتجلى أهميتها بالنسبة للفرد في كونها الجزاء العادل مقابل الجهد الذي يبذله الموظف في تحقيق أهداف الوظيفة العامة على خير وجه، بما يحقق له الاستقرار المادي الذي يشبع حاجاته ويعينه على تكاليف الحياة، وهذا ما استشعره سيدنا علي بن أبي طالب وأوصى به واليه على مصر الأشتر النخعي بقوله : " واسبغ عليهم الأرزاق فإن ذلك قوة لهم على استصلاح أنفسهم، وغنى لهم عن تناول ما تحت (r)."يديهم، وحجة عليهم إن خالفو ا أمرك أو ثلموا أمانتك Y - بالنسبة للإدارة، - تمثل الأجور الحافزة مجموعة من الطرق والوسائل المباحة شرعًا والتي تعطى بغرض تحريك وتوجيه جهودهم نحو تحقيق المزيد من حصيلة

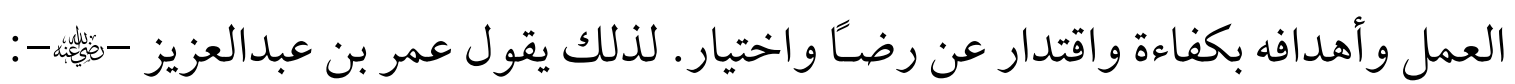
" ما طاوعني الناس على ما أردت من الحق حتى بسطت لهم من الدنيا شيئًا ". (r)

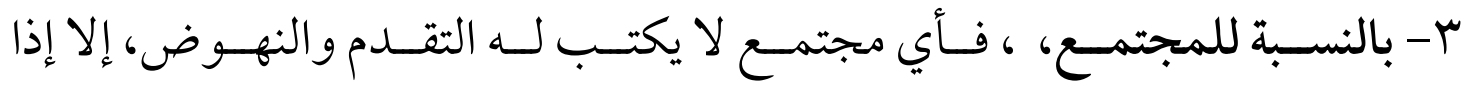

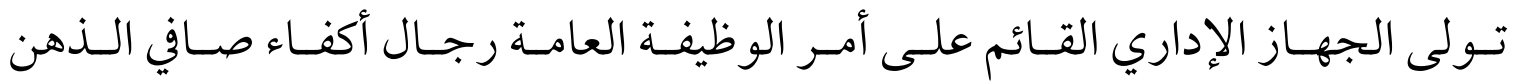

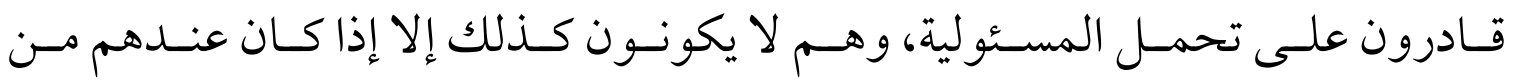

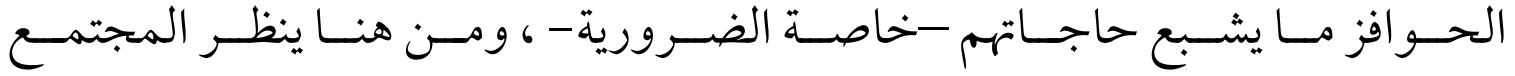

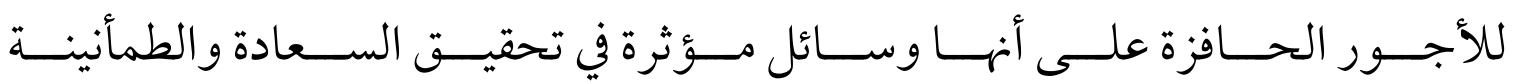

$$
\begin{aligned}
& \text { (1) عبدالحميد عبدالفتاح المغربي: الإدارة الذكية لتنمية الموارد البشرية، ص Or. }
\end{aligned}
$$

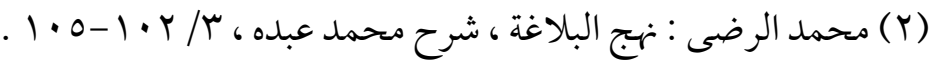

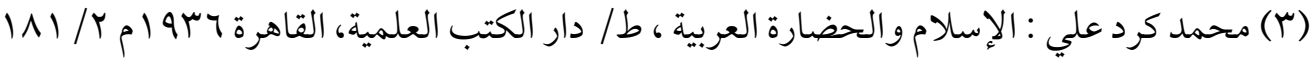




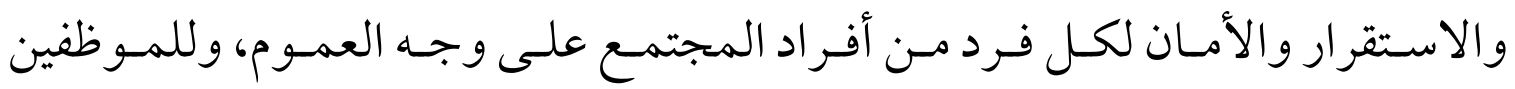

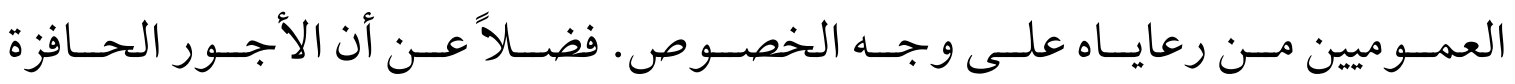

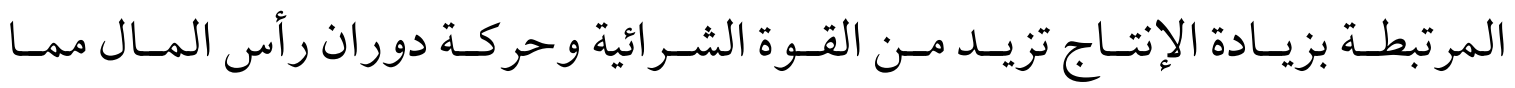
يؤدي انتعاش السوق وزيادة فرص العمل، ومن ثم ارتقاء المجتمع وتقدمه. وتحقق الأجور الحافزة في الإسلام أمرين مهمين :-الأول : تحقيق العدالة بين

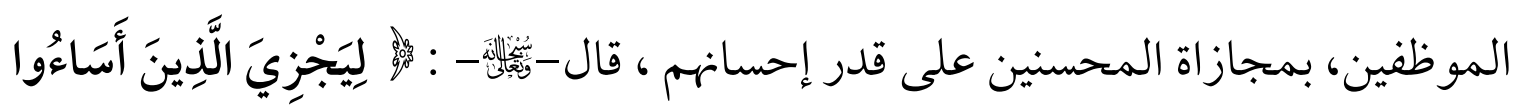

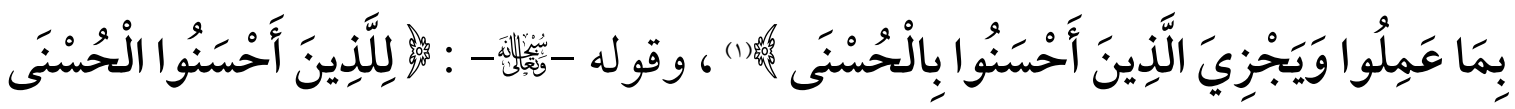

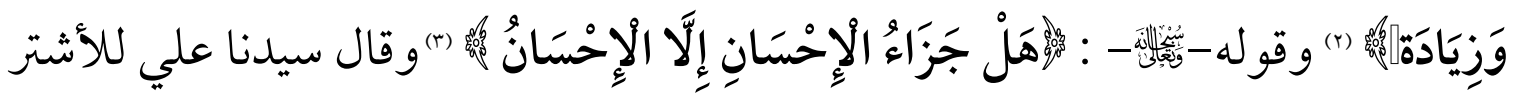
النخعي : " ولا يكونن المحسن والمسيء عندك بمنزلة سواء فإن في ذلك تزهيد لأهل الإحسان في الإحسان، وتدريب لأهل الإساءة على الإساءة، والزم كلا منهم ما ألزم نفسه "(s)

والأمر الآخر: هو تحريك وتوجيه جهود الأفراد نحو تحقيق أهداف العمل بكفاءة عالية طواعية وعن رضَّ وإخلاص وتفانٍ (م).

$$
\begin{aligned}
& \text { (1) سورة النجم من الآية (1) . (Y). }
\end{aligned}
$$

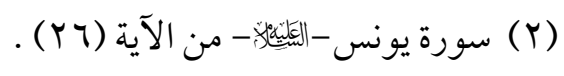

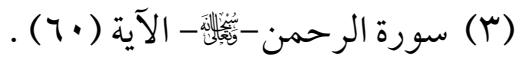

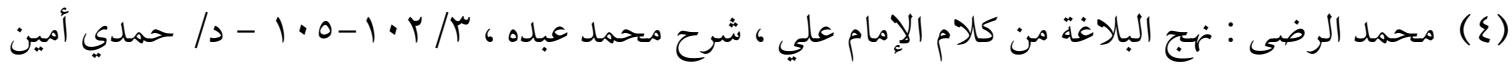

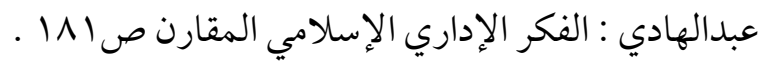

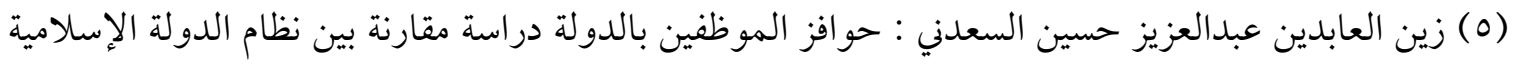

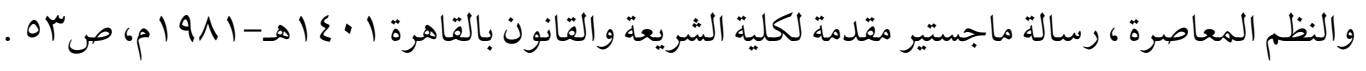


والخلاصة أن الأجور الحافزة في مجال الوظيفة العامة تعتبر مدخلاً إنسانيًا يمكن للإدارة عن طريقه تنمية كفاءة الموظفين عن طريق إثارة الرغبة لديهم للقيام بعملهم على نحو أفضل، ومن ثم يجب أن تكون هذه الأجور قادرة على كفايتهم ماليً ورعايتهم صحيًا واجتماعيًا حتى لا نسمع من الموظفين العبارة الشهيرة التي تتردد كثيراً على الآذان "على أد فلوسهم " .

\section{المطلب الثاني مكونات الأجـور الحـافزة}

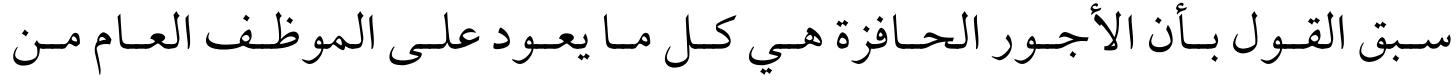

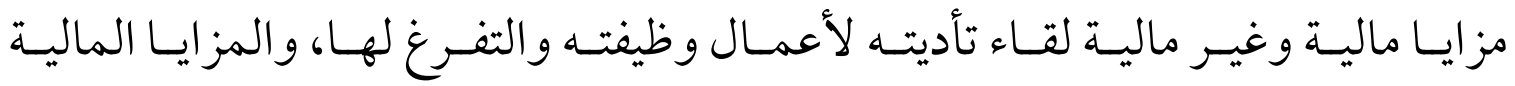
هـي المبـالغ النقديـة أو العطايـا العينــة التـي تعطى للمــوظفين لإثـارة الرغبـة لـديهم

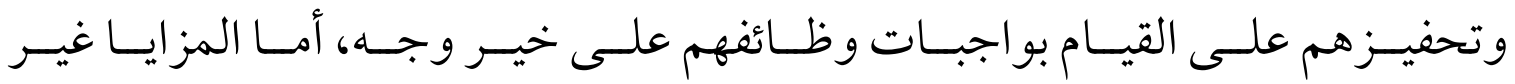

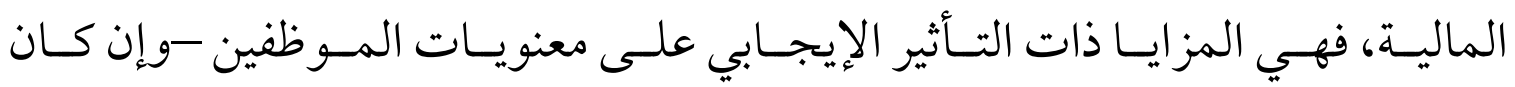

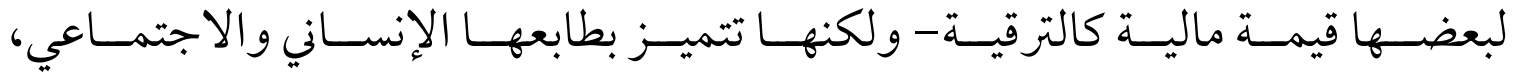

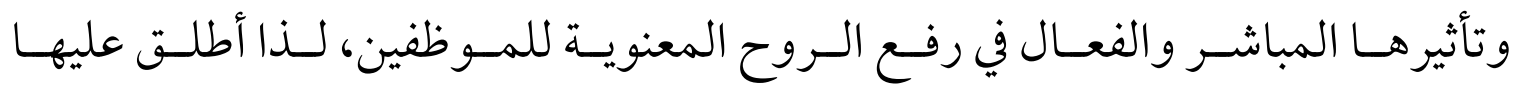

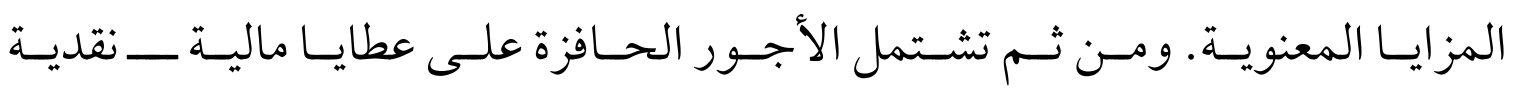
أو عينية ، وعطايا غير مالية ــمعنوية .

وقد أشارت محكمة القضاء الإداري المصرية في حكم لها بتاريخ 7 مايو عام به 90 ام، إلى الصفة التحفيزية للأجور، ومكوناتها، والاعتبارات التي يجب على الإدارة مراعاتها عند تقدير هذه الأجور، فقالت،" فمرتب الموظف تحدده القوانين واللوائح بصفة عامة وموضوعية، وهذا التحديد لا يقوم فقط على الموازنة بين العمل وما يقابله 
من جزاء فحسب، بل يراعى في تحديده ما ينبغي أن يتوافر للموظف من مزايا مادية وأدبية تتناسب مع المركز الاجتماعي اللائق بالوظيفة، مما يجنب الموظف انشغال البال بمطالب الحياة وضرورياتها، ومن ثم يكفل سير المرفق العام الذي يقوم عليه...(وأن المرتب) يشمل كذلك جميع المزايا المتعلقة بالوظيفة مادية كانت أو أدبية، عينية كانت أو نقدية، إذ تعتبر ملحقات المرتب (داخلة في) المرتب الأصلي وتأخذ حكمه، كالمرتبات الإضافية، وبدل السفر، وعلاوة الغلاء وبدل الغذاء، وبدل السكن والملابس والاغتراب، وبدل الإقامة في المناطق النائية، وبدل العيادة، وبدل العدوة للأطباء، وبدل التمثيل، ... و السفر بالسكة الحديد أو غيرها من وسائل النقل."(1) وإذا كانت النظم الوضعية قد عرفت نظام الأجور الحافزة بمشتملاتها، فإن الشريعة الإسلامية قد سبقتها في ذلك بقرون عدة، حيث تبنت نظامًا متكاملاً للأجور يحفظ للموظف كرامته ويحثه على التفاني والإخلاص في القيام بواجبات وظيفته، الأصل فيه

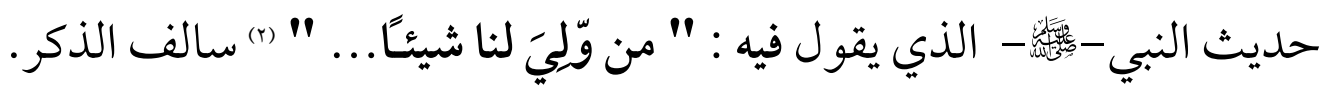
وفي الصـفحات التاليـة نشسير في إيجـاز غيــر مخـل وإطنـاب غيــر ممـل إلى أهــم

(1) حكم محكمة القضاء الإداري في 7 مايو 1901م، مجموعة مجلس الدولة لأحكام القضاء الإداري، السنة

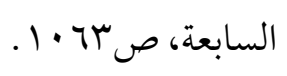

(Y) ابن خزيمة : صحيح بن خزيمة ، باب إذن الإمام للموظف بالتزويج واتخاذ الخادم و المسكن من الصدقة ،

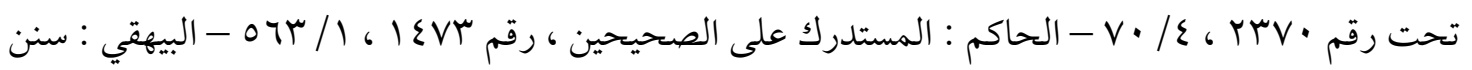

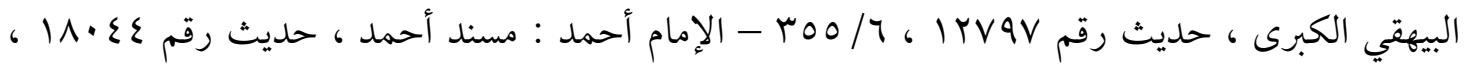


هـذه العطايـا التي تعـد مـن مكونـات الأجـور الحـافزة في الـنظم الوضـعية والشـريعة

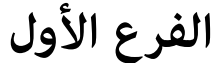 \\ مكونات الأجور الحافزة في النظم الوضعية}

تشـتمل الأجـور الحـافزة علسى عـدة مــوارد ماليـة وغيــر ماليـة للموظـف العـام،

فمن مشتملات الأجور الحافزة المالية، ما يلي:

أولاً : المرتبات أو الأجور (1):

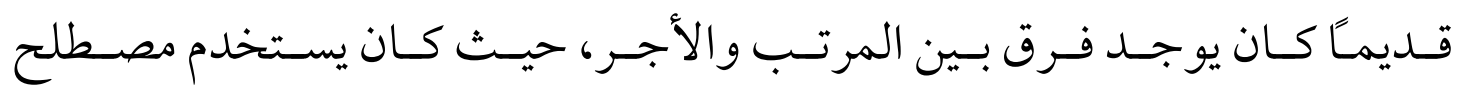

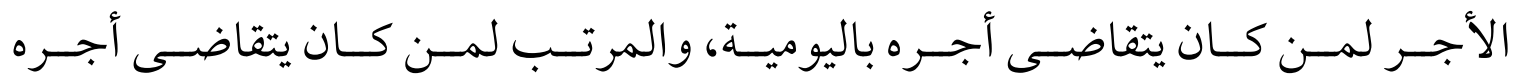

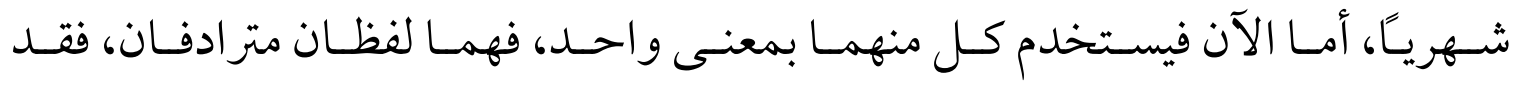

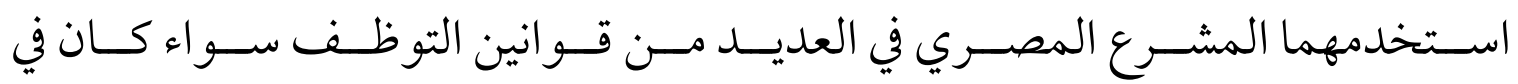
القطاع العام أو الدولة بمعنى واحد).

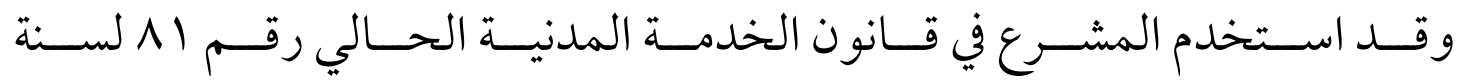

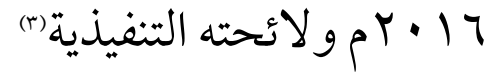

(1) د/ نبيل رسلان : الحوافز في قوانين الموظفين بالحكومة والقطاع العام ص1/ 11 - ويراجع تفصيلاً د/ علي

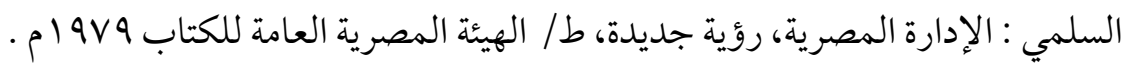

(Y) فقد استخدم المشرع المصري في القانون المدني مصطلح الأجور، وكذلك في قانون الموظفين المدنيين

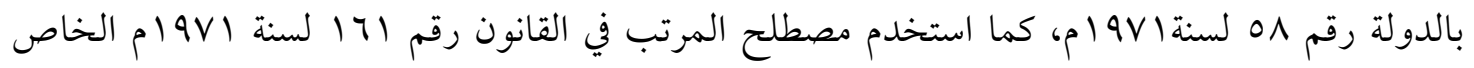
بالموظفين بالقطاع العام، واستخدم مصطلح الأجور في قانون الموظفين بالدولة الملغي رقم Vع لسنة

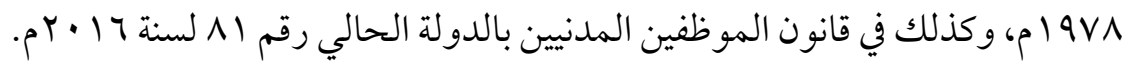

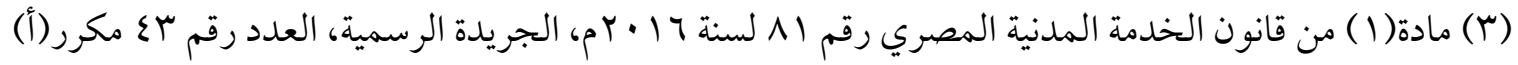


مصـطلح الأجــور، وذلـك في البـاب الخـامس منـه، ونـص في المـادة رقــم (1)

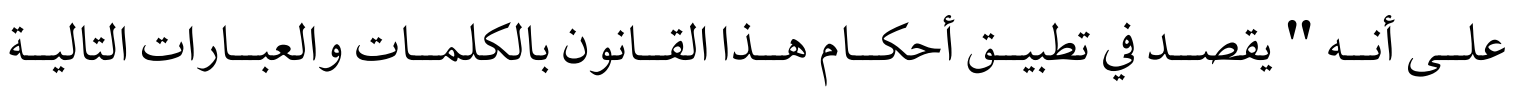
المعني المبين قرين كل منها $\ldots-1$

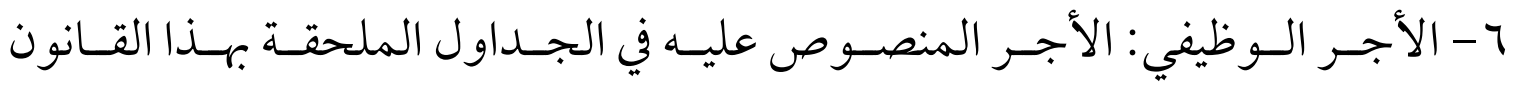
مضمومًَ إليه جميع العلاوات المقررة بمقتضى هذا القانون.

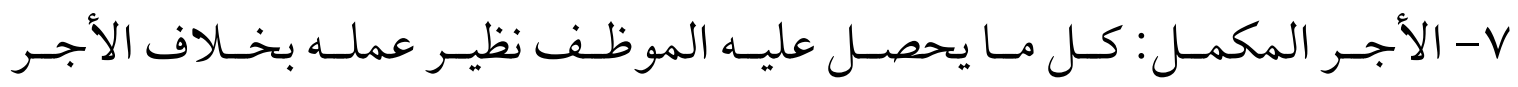
الوظيفي.

^- كامـل الأجر : كل مـا يحصل عليـه الموظف نظير عمله مـن أجـر وظيفي وأجـر

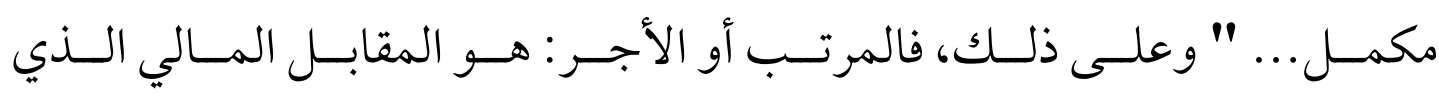

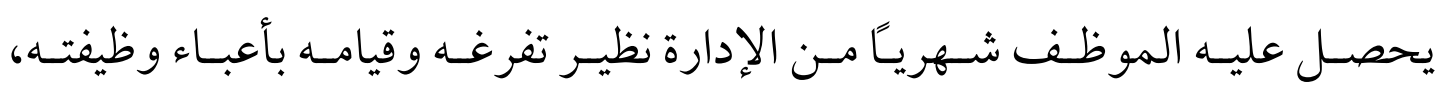
لمواجهة تكاليف معيشته. (1)

في أول نوفمبرج 1 • Yم، والمادة(Y) من اللائحة التنفيذية لقانون الخدمة المدنية الصادرة بقرار رئيس مجلس

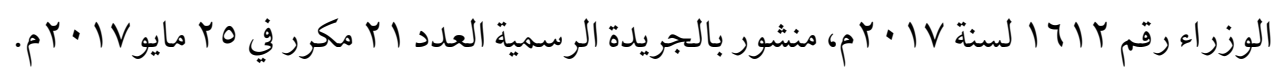
(1) د/ سليمان الطماوي: الوجيز في القانون الإداري صبr آع - - د/ مصطفى أبو زيد فهمي : الوجيز في القانون

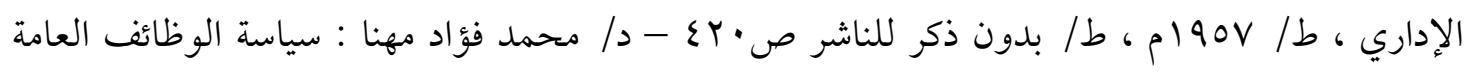
وتطبيقاتها في ضوء مبادئ علم التنظيم صريمب - د/ أنور رسلان : الوظيفة العامة، ط/ دار النهضة العربية،

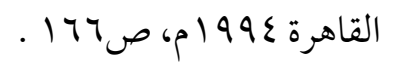

وقالت الجمعية العمومية لقسمي الفتوى والتشريع بمجلس الدولة : " إن الموظف يستحق أجراً مقابل ما يؤديه من عمل، كما يستحق بدلات ومز ايا أخرى ربط المشرع بينها وبين ما يؤديه من عمل برباط لا انفصام له " .

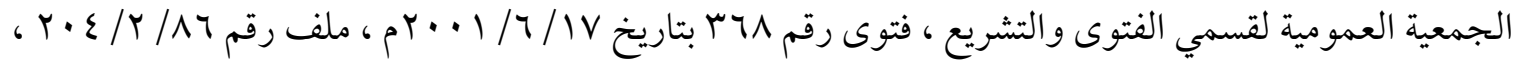


لـذا يجــب علـى الدولـة عنـــ تقــديرها للأجــور أن تراعـي تكــاليف وأعبــاء

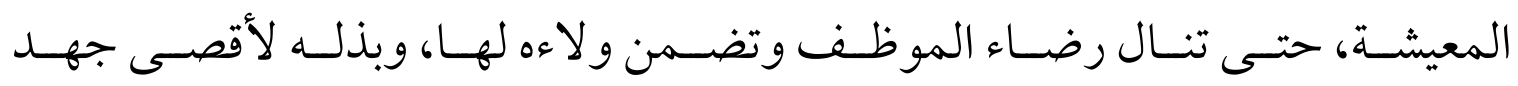
ممكن في أداء عمله .

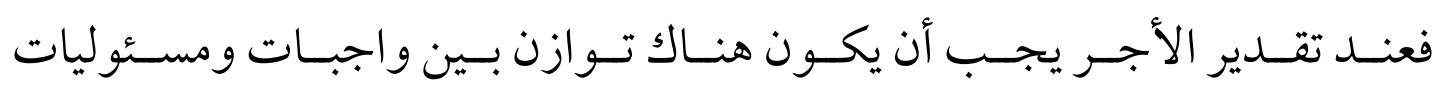

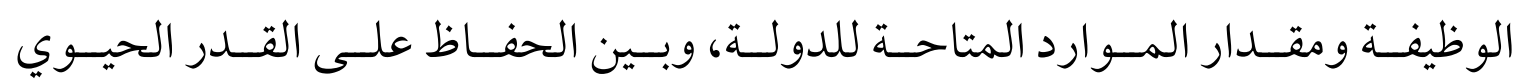
للمعيشــة وتكــاليف أعبــاء الحيــاة العائليـة للموظــف، حتــى تحــفظ المرتبــات بصـفتها التحفيزيـة لرفـع الـروح المعنويـة عنــد المـوظفين، ومسن ثـم تحقيـق الكفايـة الإنتاجية في الوظيفة العامة.

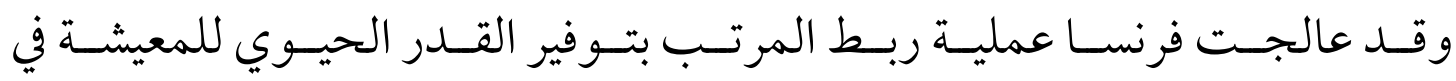

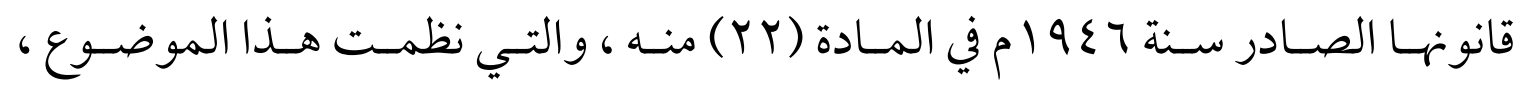
فاشترطت ألا يقل المرتب المربوط

لأول مرة عن · باء٪ من القدر الحيوي ، ويقصد بالقدر الحيوي المبلغ الذي لا يمكن بدونه مو اجهة الحاجات الأساسية للإنسان(1). ونظراً لأن نفقات المعيشة متقلبة بين الارتفاع والانخفاض، فقد لجأت بعض

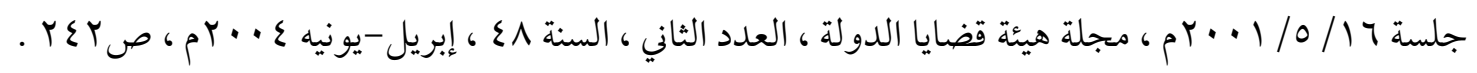
ويرى البعض أن المرتب أو الأجر هو نصيب الموظف أو الموظف من الدخل القومي يتحدد بما يضمن

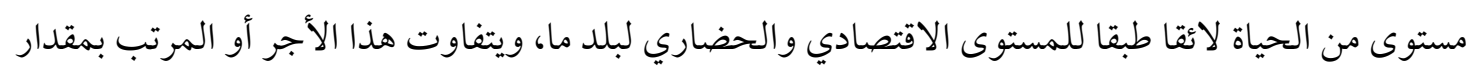
ما يساهم به الموظف في تكوين هذا الدخل القومي. راجع د. حماد محمد شطا: النظام القانوني للأجور

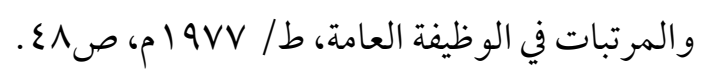

(1) محمود عاطف البنا : دراسات في الوظيفة العامة في النظام الفرنسي ، ط/ بدون تاريخ أو ذكر للناشر صـ ـ ـ1 . 
الدول إلى إعادة النظر في المرتبات بصفة دورية لعلاج جمودها بالنسبة لتقلب الأحوال الاقتصادية، فمثلاً السويد كان يعاد النظر في المرتبات كل خمس أو ست سنوات، ثم أصبح يعاد النظر فيها سنويتًا، كما هو الحال في فرنسا").

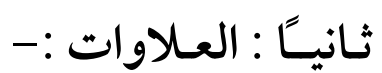

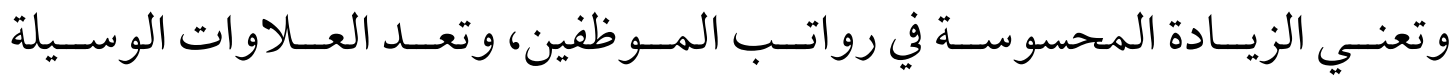

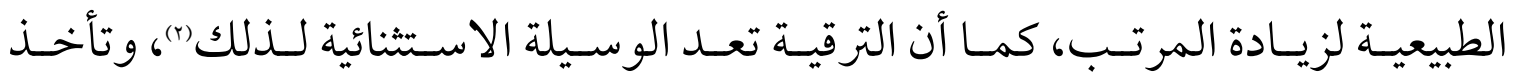
العلاوات في التطبيق العملي عدة صور:

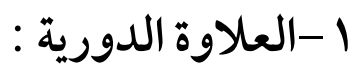
وهي زيادة مرتبات الموظفين بطريقة متنظمة وفق ضوابط محددة ، دون تغيير في

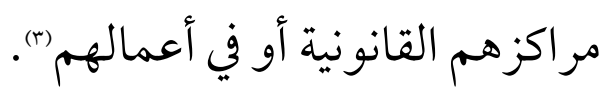
ويتوقف أثثر العلاوة الدورية على أداء الموظفين وتحفيزهم على الفلسفة التي تمنح على أساسها هذه العلاوة، فإذا كانت تمنح للموظف باعتبارها مسألة اجتماعية تقابل أعباء عائلية فإن تأثيرها على كفاية الموظف يكون ضئيلاً لأن الجميع يتساوى فيها وإن كان يتم تأجيل موعد منحها لضمان الحد الأدنى من الكفاية-، وإذا كانت تمنح

(1) يراجع تقرير لجنة دراسة الوظائف العامة في بورما صهه ، أشار إليه د/ حمدي أمين : إدارة شئون موظفي

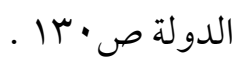

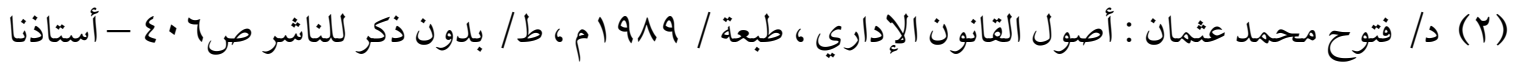

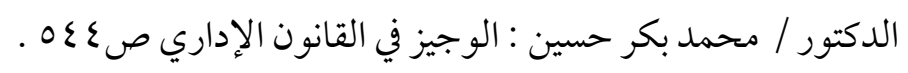

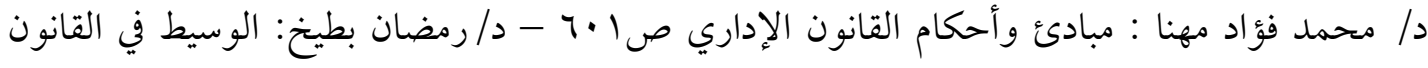

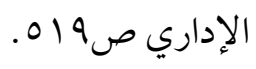


على أساس أنها مكافأة للموظف على تفوقه وتميزه في أداء عمله فإن تأثيرها على كفاية الموظف يكون كبيراً ، لأنها -العلاوة- في هذه الحالة تكون متفاوتة بتفاوت كفاءة

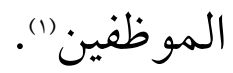

ولقد نصت المادة (rV) من قانون الخدمة المدنية المصري الحالي رقم اN لسنة 17 أب على أن " يستحق الموظف علاوة دورية سنوية في الأول من يوليو التالي لانقضاء سنة من تاريخ شغل الوظيفة، أو من تاريخ استحقاق العلاوة الدورية السابقة بنسبة (V٪) من الأجر الوظيفي، على أن يعاد النظر في هذه النسبة بصفة دورية متنظمة. " ضوابط استحقاق العلاوة الدورية في قانون الخدمة المدنية المصري الحالي رقم 11

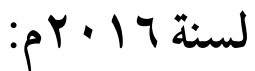
أ-لابد من انقضاء سنة على الأقل سواء من تاريخ استحقاق العلاوة السابقة و من تاريخ

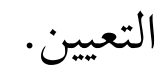
ب-لا يقل مقدار العلاوة الدورية عن V٪ من الأجر الوظيفي الذي يحصل عليه

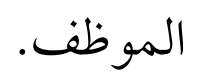

ج--على السلطة المختصة ضرورة النظر في قيمة العلاوة الدورية بشكل دوري ومنتظم

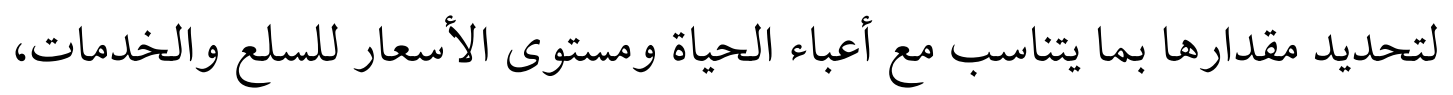
وهذه نظرة إنسانية استحدثها المشرع في قانون الخدمة المدنية الحالي، حيث أتاح للسلطة المختصة إعادة النظر في مقدار هذا العلاوة بشكل دوري بالزيادة للتناسب مع غلاء الأسعار. 
د- راعى المشرع في قانون الخدمة المدنية الحالي البعد الإنساني للأجور وما تمثله من أهمية كبيرة للموظف وأسرته، فقد تكون الدخل الوحيد لهم، لذا حمى هذه العلاوة من العبث بها وقرر حمايتها، فلا يجوز بأي حال من الأحوال حرمان الموظف من هذه العلاوة ولا جزء منها، وذلك بعكس سياسة المشرع في قوانين التوظف السابقة، حيث كان الموظف يحرم من كامل هذه العلاوة أو من نصفها إذا قدم عنه تقرير سنوي بمرتبة ضعيف") هـ- العلاوة الدورية مقررة بمقتضى القانون، ولا تحتاج لاستحقاقها قرار من السلطة المختصة، بمجرد حلول ميعادها تكون من حق الموظف، وهذا بعكس ما كان عليه

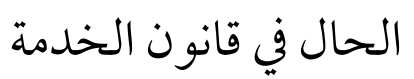
المدنية السابق، حيث كان يلزم لمنحها صدور قرار من السلطة المختصة بذلك).. و - استخدم المشرع لفظ " استحقاق" وهو نفس اللفظ الذي استخدمه قانون الموظفين المدنيين الملغي السابق بدلاً من لفظ " منح " الذي كان وارداً في التشريعات

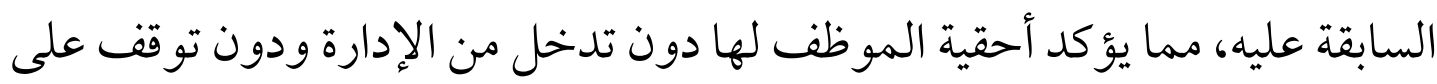
إصدار قرار منها، وحتى عندما نص المشرع في قانون الموظفين المدنيين على ضرورة منحها بقرار من السلطة المختصة، يعتبر قرارها بأحقية الموظف للعلاوة

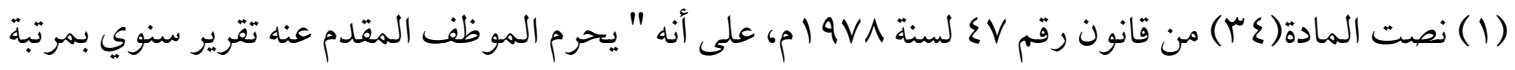

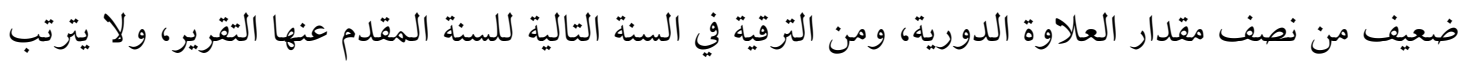
الأثر السابق إذا ما تراخى وضع التقرير عن الميعاد الذي يتعين وضعه فيه".

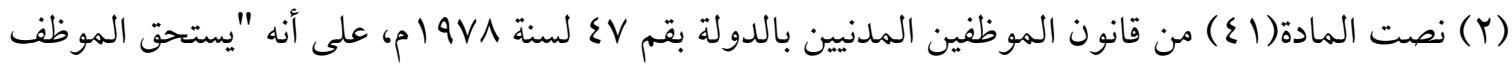

العلاوة الدورية المقررة لدرجة وظيفته التي كان يشغلها...ويصدر بمنح العلاوة قرار من السلطة المختصة. " 
قراراً كاشفـً للمركز القانوني الذي أنشأه القانون ، والذي تلتزم به الإدارة دون أن تمارس في ذلك أي اختصاص تقديري".). ز- موعد استحقاق هذه العلاوة هو الأول من شهر يوليو التالي لانقضاء سنة من تاريخ شغل الوظيفة، أو من تاريخ استحقاق العلاوة الدورية السابقة.

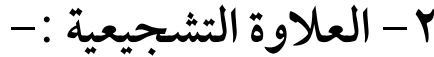

وتعتبر هذه العلاوة من مستحدثات قانون الموظفين المصري رقم 7 لسنة عاب ام"()، واحتفظ بها المشرع في قوانين التوظف التالية عليه، وقد نصت عليها المادة

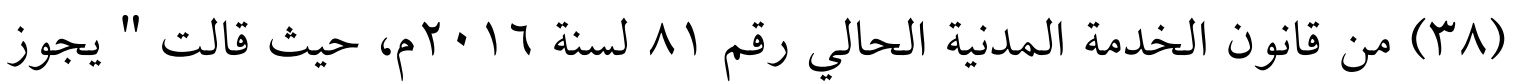
للسلطة المختصة منح الموظف علاوة تشجيعية بنسبة (0٪) من أجره الوظيفي، وذلك

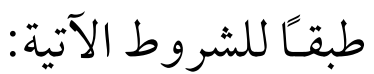

1 - أن تكون كفاية الموظف قد حُددت بمرتبة كفء على الأقل عن العامين الأخيرين. r - ألا يمنح الموظف هذه العلاوة أكثر من مرة كل ثلاثة أعوام. r- ألا يزيد عدد الموظفين الذين يُمنحون هذه العلاوة في سنة واحدة على (• (1\%) من عدد الموظفين في وظائف كل مستوى من كل مجموعة نوعية على حدة، فإذا كان

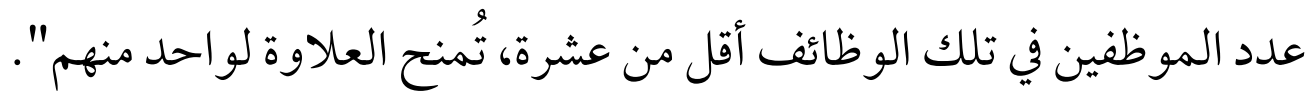

(1) يراجع في ذلك : استاذنا الدكتور / محمد بكر حسين : الوجيز في القانون الإداري صلعـه - د / عبدالفتاح

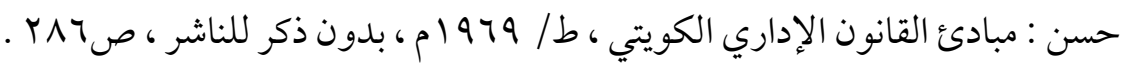

حيث نصت عليها المادة (YV) منه على هذه العلاوة، وقضت منحها للموظف اعتباراً من أول يوليو، وتعادل قيمتها العلاوة الدورية المقررة له، واشترطت منحها شروطكَ من أهمها : أن تكون كفاية الموظف قد حددت بمرتبة ممتاز في العامين السابقين على منحها 
ضوابط استحقاق العلاوة التشجيعية في قانون الخدمة المدنية المصري الحالي رقم

: 1771

أ-هذه العلاوة جوازية، بمعنى أنه يمكن منحها كما يمكن عدم منحها -بشرط عدم

إساءة استعمال السلطة- وفي حالة منحها يصدر قرار بذلك من السلطة المختصة .

ب- تقدر هذه العلاوة بنسبة(ه٪) من الأجر الوظيفي الذي يحصل عليه الموظف، والأجر الوظيفي طبقا لهذا القانون، هو الأجر المنصوص عليه في الجداول الملحقة

ههذا القانون مضمو مـا إليه جميع العلاوات المقررة بمقتضى هذا القانون(1) .

ج-يشترط فيمن يمنح هذه العلاوة أن تكون كفايته قد حددت بمرتبة كفء على الأقل في العامين الأخيرين عن العام التي ستمنح فيه هذه العلاوة() ، وقد كان قانون الموظفين المدنيين السابق يشترط زيادة على هذا الشرط، أن يكون الموظف قد بذل جهداً خاصًَ أو حقق اقتصاداً في النفقات أو رفعًا لمستوى الأداء(r) ، غير أن قانون الخدمة المدنية خلى من النص على مثل هذا الشرط، واكتفى بحصول الموظف على مرتبة كفء عند تقدير كفايته في العامين الأخيرين، والمشرع سلك هذا المسلك ليحقق أمرين، أحدهما: حث الموظف على الاجتهاد في أداء واجبات وظيفيته لكي يحصل على مرتبة كفء أو ممتاز عند تقدير كفايته، ومن ثم يكون

(1) راجع نص المادة( / / ) من قانون الخدمة المدنية المصري الحالي، ويراجع الملاحق في نهاية البحث، حيث أوردنا جداول الوظائف المرفقة بقانون الخدمة المدنية الحالي للاهتداء بها.

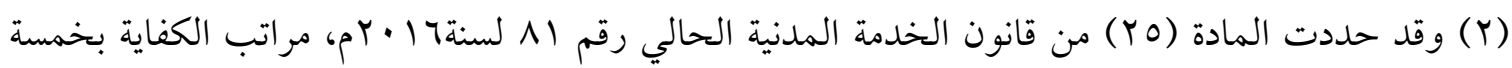
مراتب، وهي، ممتاز، كفء، فوق المتوسط، متوسط، ضعيف.

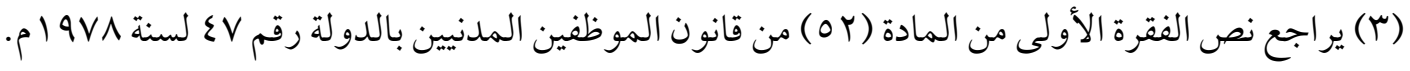


مستحقَّ لهذه العلاوة. والأمر الآخر: زيادة دخل الموظف لمواجهة مصاعب الحياة وارتفاع الأسعار المستمر للسلع والخدمات. وهذه نظرة إنسانية من المشرع للموظف لتحسين مستو اه الاجتماعي. د-يشترط كذلك ألا يمنح الموظف هذه العلاوة أكثر من مرة كل ثلاثة أعوام، وقد كان

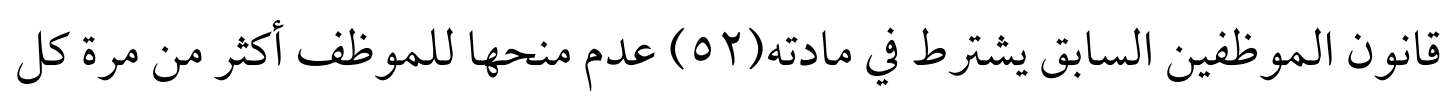
سنتين. هـ-وفي جميع الأحوال يجب ألا يزيد عدد الموظفين الذين يُمنحون هذه العلاوة في سنة

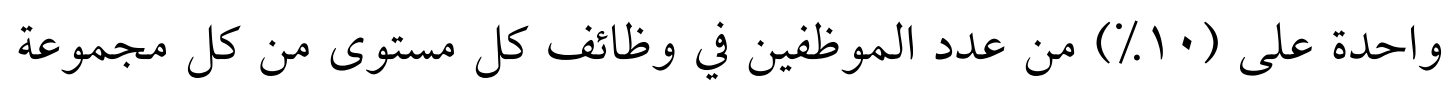
نوعية على حدة، ومع ذلك إذا كان عدد الموظفين في تلك الوظائف أقل من عشرة، تُمنح العلاوة التشجيعية لواحد منهم. هذا ولا يمنع منح العلاوة التشجيعية من استحقاق العلاوة الدورية في موعدها المقرر لها . و - تقوم إدارة الموارد البشرية بإعداد بيانًا بأسماء الموظفين الذين يجوز منحهم العلاوة التشجيعية وفق الشروط والضوابط السابقة وتعرضه على لجنة الموارد البشرية الموجودة بالوحدة الإدارية، أو السلطة المختصة، وعند التزاحم في الحصول على العلاوة التشجيعية، يفضل الأعلى في مرتبة الحصول على تقويم

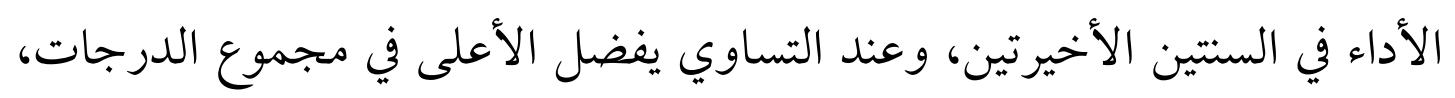
فالأقدم في ذات المستوى الوظيفي (1).

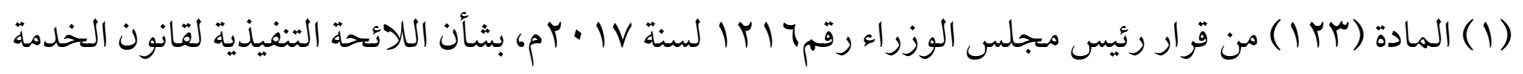

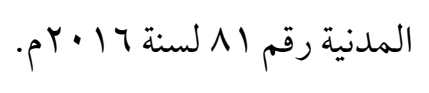


ويتضح من الأحكام السابقة للعلاوة التشجيعية، أنها تختلف عن العلاوة الدورية، ومن أهم مواطن الخلاف بينهما، أن التشجيعية جوازية تتمتع الإدارة بسلطة تقديرية

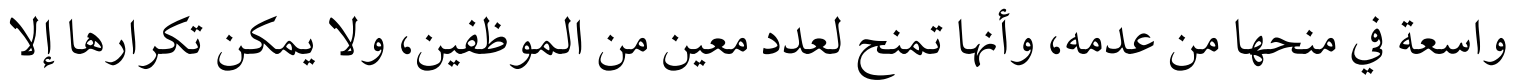
بعد مرور ثلاثة أعوام، أما العلاوة الدورية، فهي وجوبية بعد مرور سنة على التعيين، وتستحق لجميع الموظفين سنويتً، بشكل دوري.

r- حافز التميز العلمي (العلاوة التشجيعية لمن يحصل على مؤهل أعلى ) : أجاز القانون منح علاوة تشجيعية للموظفين الذين يحصلون أثناء خدمتهم على مؤهل أعلى لا يقل عن (V) وفقـَ للقو اعد والإجراءات التي يصدر بها قرار من رئيس مجلس الوزراء، فقد نصت المادة (q؟r) من قانون الخدمة المدنية الحالي على أن "يستحق الموظف الذي يحصل على مؤهل أعلى أثناء الخدمة حافز تميز علمي. ويمنح الموظف هذا الحافز إذا حصل على دبلومة مدتها ستتان دراسيتان على الأقل، أو على درجة الماجستير أو ما يعادلها أو دبلومتين من دبلومات الدراسات العليا مدة

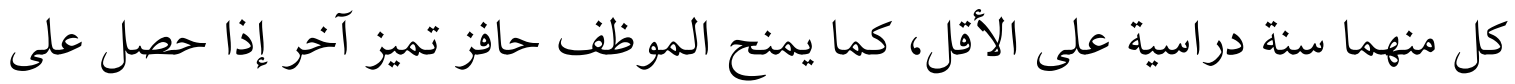
درجة الدكتوراه أو ما يعادلها. ويكون حافز التميز العلمي المشار إليه بنسبة (v٪) من الأجر الوظيفي، أو الفئات

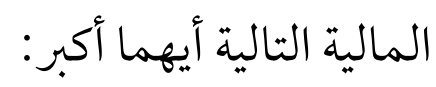
OY جنيهً شهريَّا لمن يحصل على مؤهل متوسط أو فوق المتوسط. • 0

O جنيةًا شهريًا لمن يحصل على دبلومة مدتها سنتان در اسيتان على الأقل.

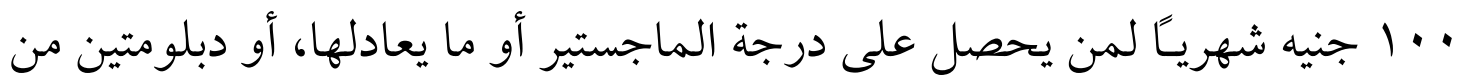


دبلومات الدراسات العليا مدة كل منها سنة دراسية على الأقل.

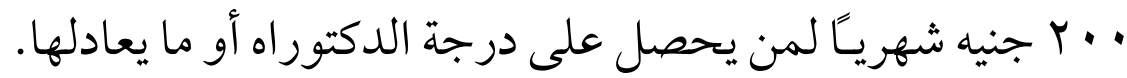
وتحدد اللائحة التنفيذية شروط وضوابط منح حافز التميز، على ألا يجوز منح هذا الحافز أكثر من مرة عن ذات المستوى العلمي".

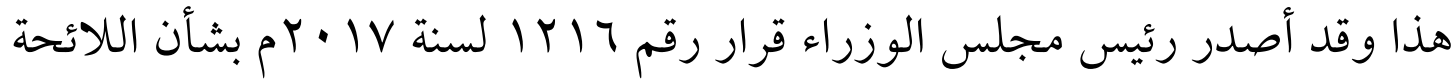
التنفيذية لقانون الخدمة المدنية، مبينًا ضو ابط وإجراءات منح هذه العلاوة، وذلك على

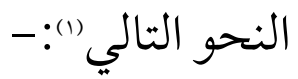

أ- استخدم المشرع لفظ " استحقاق" بدلاً من لفظ " منح "، مما يؤكد أحقية الموظف لحافز التميز العلمي كعلاوة تشجيعية دون تدخل من الإدارة، وإن كان منحها يحتاج إلى قرار من السلطة المختصة، غير أن هذه القرار يعتبر قرارًا كاشفتًا للمركز القانوني الذي أنشأه القانون ، والذي تلتزم به الإدارة دون أن تمارس في ذلك أي اختصاص تقديري. ب- مقدار العلاوة وفئات الموظفين المستحقين لها:- تقدر هذه العلاوة ب (V/) من الأجر الوظيفي كحد أدنى، وتمنح للفئات التالية وفق الضو ابط الآتية: - الموظفون من غير حاملي المؤهلات العلمية: يمنح هؤلاء حافزاً علميًا وفق الضوابط التالية: - خمسة وعشرون شهريًا جنيهًا لمن يحصل على مؤهل متوسط، أو فوق متوسط، ، أو (\%) 
- خمسون جنيهًا شهريًا لمن يحصل على مؤهلٍ عالٍ، ، أو (V٪) من الأجر الوظيفي أيهما أكبر.

- الموظفون حاملي المؤهلات العليا: يمنح هؤلاء الموظفون حافز تميز مقداره (V٪) على الأقل شهريًا من الأجر الوظيفي ، أو حسب الفئات المالية التالية عند حصولهم أثناء خدمتهم على أي من المؤهلات التالية: - خمسة وسبعون جنيهً شهريًا لمن حصل على دبلومة مدتها سنتان دراسيتان على الأقل، أو (V/) من الأجر الوظيفي أيهما أكبر.

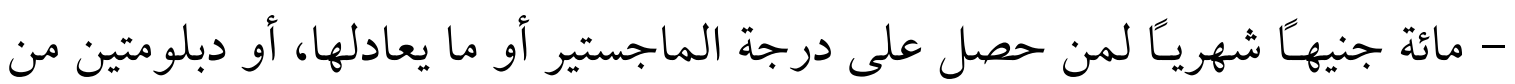

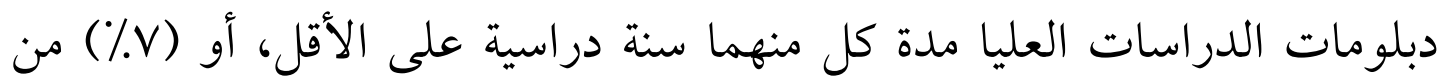
الأجر الوظيفي أيهما أكبر. - الموظفون حاملي درجة الماجستير أو ما يعادلها: يمنح هؤلاء مائتي جنيه شهريًا كحافز علمي إذا حصلوا على درجة الدكتوراه، أو ما يعادلها، ولا يجوز حرمانهم من هذا الحافز كونهم سبق لهم الحصول على حافز علمي من الفئات السابقة، إذا

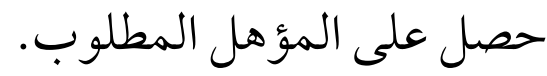

ج-يشترط لاستحقاق هذه العلاوة أن يكون المؤهل الذي حصل عليه الموظف متصلاً بطبيعة الوظيفة التي يشغلها، وله علاقة بها حتي يستفيد منه في ممارسة مهام وظيفته، ويرجع في تقدير ذلك إلى السلطة المختصة، أو لجنة الموارد البشرية الموجودة بالوحدة الإدارية، بعد أن يتقدم الموظف بطلب مدعوما بما يثبت حصوله على

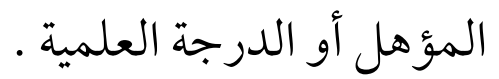
د- فيما يتعلق بإجراءات الحصول على هذا الحافز، يجب أن يتقدم الموظف بطلب 
لإدارة الموارد البشرية بالوحدة الإدارة التي يعمل بها مدعمًا بالمستندات التي تفيد حصوله على المؤهل أو الدرجة العلمية الأعلى، وتقوم الإدارة بإعداد بيان تفصيلي بالمستحقين لحافز التميز العلمي، وتعرضه في خلال شهر من تقديم الطلب على السلطة المختصة، إذا كان الموظف من شاغلي الوظائف القيادية، أو وظائف الإدارة الإشرافية، أو على لجنة الموارد البشرية في أول اجتماع تالٍ لها بعد تقديم الطلب، إذا كان الموظف من شاغلي باقي الوظائف. هـ- تستحق هذه العلاوة من تاريخ اعتماد السلطة المختصة للبيان الذي أعدته إدارة الموارد البشرية، وذلك بالنسبة لشاغلي الوظائف القيادية، ووظائف الإدارة الإشرافية، ومن تاريخ اعتماد محضر اجتماع لجنة الموارد البشرية بالنسبة لباقي الوظائف .

و - عدم منح هذا الحافز أكثر من مرة عن ذات المستوى العلمي، مهما تعدد مرات الحصول على نفس المؤهل المستحق عنه الحافز، بمعنى إذا حصل الموظف على أكثر من ماجستير، أو أكثر من دكتوراه، فلا يستحق الحافز إلا لمرة واحدة، مهما تعددت مرات حصوله عليها، لكن إذا حصل الموظف على حافز الحصول على درجة الماجستير، ثم أكمل دراسته وحصل على درجة الدكتوراه، استحق حافز الحصول على الدكتوراه. ونخلص، إلى أنه يمكن تكرار الحصول على حافز التميز العلمي بتكرار الحصول على المؤهل الأعلى. وتعد العلاوات السابقة من أهم وسائل الإدارة للحصول على رضا الموظف عن أعمال وظيفته، لذا تضاف هذه العلاوات للأجر الوظيفي الذي يتقاضاه الموظف شهريًا، حيث نصت المادة ( • ع) من قانون الخدمة المدنية المصري الحالي رقم 11 
لسنة 17 أبم، " تُضم العلاوات المقرر بمقتضى هذا القانون إلى الأجر الوظيفي

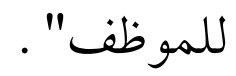

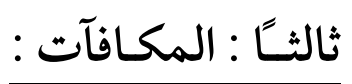

وهي نوع من التحفيز المادي للموظف بإثابته ماليًا على ما بذل من جهد (1).

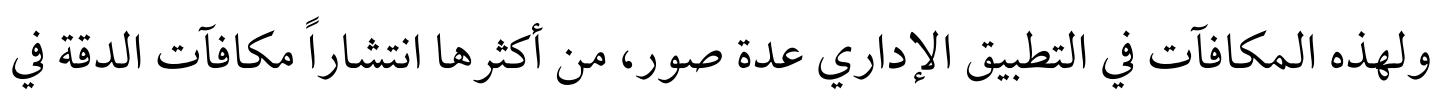
العمل التي تمنحها البرازيل وإسبانيا والهند والبرتغال واليابان لمحصلي الغاز والمياه والكهرباء ، ومكافأة الخدمة الحسنة التي يحصل عليها الجنود في الإدارات الفيدرالية الأمريكية، والتي تصل إلى ثلاثين مليون دولار، ومنها أيضًا المكافآت التي تمنح لمجيدي اللغات من الموظفين في ألمانيا وفلنده وأيرلنده ، وكذلك المكافآت التي تمنح على سرعة الاختز ال في فرنسا"). ومن أهم صور المكافآت وأكثرها شيوعـا المكافآت التي تمنح على الاختراعات التي يبتكرها الموظف، وكذلك الاقتراحات التي يتقدم بها لجهة الإدارة لتحسين أداء العمل، ويبرر منح هذه المكافآت أن الموظفين يؤدون عملاً فوق ما هم مطالبون به قانونًا، وأثبتت التجارب والإحصائيات أن هذه المكافآت تعد من قبيل الاستثمار

د/ نبيل رسلان : الحوافز في قوانين الموظفين بالحكومة والقطاع العام ، رسالته السابق الإشارة إليها

$$
\text { صN }
$$

، السيد / هربرت برمش : زيادة فاعلية الإدارة بواسطة المزايا المختلفة التي تمنحها لموظفيها (r)

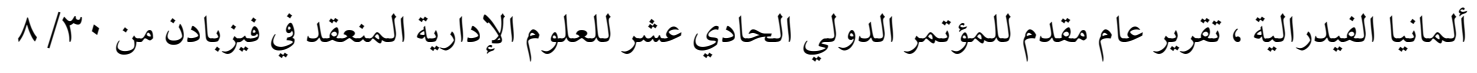

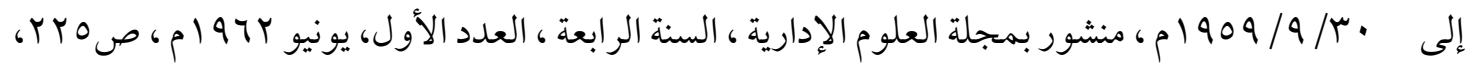


المجزي للدولة ، كما هو واضح من التقرير الذي أعدته أمريكا في سنة 901 (م، حيث

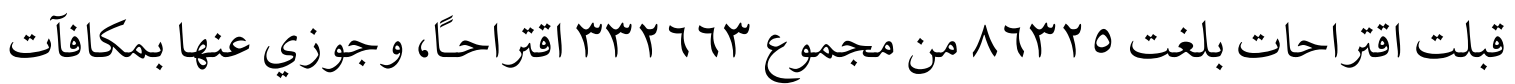
بلغت ...... . . . دولار ، ولكن العائد الذي حققته هذه الاقتراحات وصل إلى

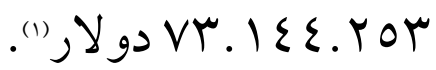

فالمكافأة تهدف إلى تشجيع الموظف على البحث والاختراع والمزيد من الاقتراحات التي تحسن وتعدل من أسلوب العمل في الوحدة الإنتاجية، مما يعود على المنظمة بالربح الوفير والخير العميم، وفي نفس الوقت تسعى الإدارة من ورائها الحصول على رضا الموظف عن العائد الذي يعود عليه من الوظيفة التي يشغلها. وتمتاز هذه المكافآت عن غيرها من صور الزيادات المختلفة في المرتبات بأنه يمكن منحها بمجرد إثبات جدارة الموظف دون انتظار تاريخ معين -كما هو الحال في العلاوة الدورية- مما يدفع الموظف إلى بذل كل جهد حتى يظفر بهاب().

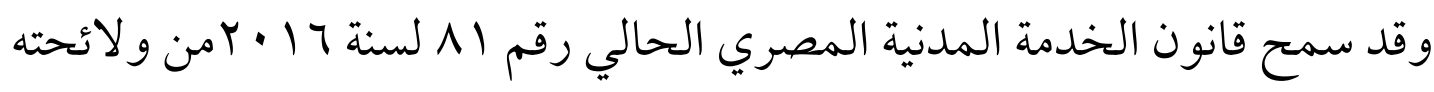
التنفيذية بمنح مكافآت خاصة للموظفين لها ما يبررها، نذكر منها :أ-مكافأة تحسين طرق العمل، يمنح الموظف هذه المكافأة وفق الضو ابط التالية(r):-

(1) السيد / هربرت برمش : زيادة فاعلية الإدارة بواسطة المزايا المختلفة التي تمنحها لموظفيها ، مجلة العلوم

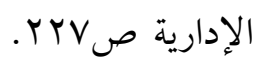

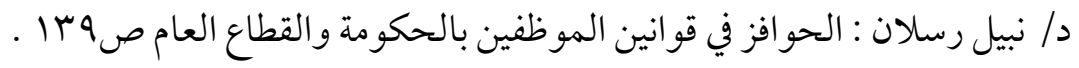
(r) وقد نصت المادة (Y ) من قانون الخدمة المدنية على أن " يجوز للسلطة المختصة تقرير مكافآت تشجيعية

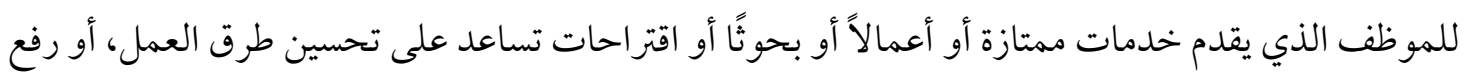
كفاءة الأداء، أو تو فير في النفقات، وذلك كله بشرط سماح البند المخصص لذلك في الموازنة العامة". 
- مقابلاً أو مكافأة عما قدمه من أعمال إضافية أو عما بذله من جهود غير عادية في أعمال كلف بها من قبل السلطة المختصة.

- إذا قدم بحوثًا أو أعمالاً أو اقتراحات مبتكرة أو خدمات ممتازة بذل فيها جهداً غير عادي

- أن تساعد هذه الخدمات والأعمال و البحوث والاقتراحات في تحسين طرق العمل، أو رفع كفاءة الأداء، أو توفير في النفقات.

- تمنح هذه المكافأة عندما يسمح البند المخصص لذلك في الموازنة العامة، وهذا أمر طبيعي، فالوظيفة إذا لم تكن ممولة لا يجوز شغلها، فمن باب أولى هذه المكافأة يجب أن تكون ممولة.

ب- مكافأة الاختراعات والمصنفات:- عرفت الدولة قيمة التقدم التكنولوجي والاستفادة منه في ممارسة واجبات الوظيفة العامة، وأثره على تحقيق المصلحة العامة، فحثت الموظف العام على التسليح بكل ما هو جديد في هذا المجال لتنمية قدراته وامكانياته للاستفادة منها في ممارسة واجبات وظيفته، وكذلك عملت على حثه لتنمية ابتكاراته التي تخدم الوظيفة العامة، لذا نجد المشرع في قانون الخدمة المدنية المصري الحالي قد رصد مكافأة مجزية وعادلة لكل من صنف أو ابتكر أفكاراً جديدة تفيد المجتمع وتنعكس على أدائه في ممارسة أعمال وظيفته. وقد صدرت اللائحة التنفيذية لقانون الخدمة المدنية مبينة ضوابط هذه المكافأة، وفيما يلي نعرض لشروط وضوابط منح مكافأة الاختراعات والمصنفات في قانون 


$$
\text { الخدمة المدنية المصري الحالي ولائحته التنفيذية(1):- }
$$

- يجب على الموظف أن يخطر الوحدة الإدارية المنتمي إليها كتابة عن أي اختراع أو مصنف يبتكره أثناء تأديته لأعمال وظيفته، بشرط أن تكون هذه الأعمال نتيجة تجارب أو بحوث أو دراسات رسمية، أو تكون هذه لها صلة بالشئون العسكرية، أو تدخل في نطاق و اجبات وظيفته . - يعوض الموظف تعويضًا عادلاً عن أعماله يحثه على بذل جهد أكبر لمزيد من الاختراعات و المصنفات التي تخدم الوطن، ويتم تقدير هذا التعويض عن طريق تشكيل لجنة بقرار من السلطة المختصة من ذوي الخبرة في مجال الوحدة التي يعمل بها الموظف المخترع، ومن ذوي التخصص في مجال الاختراع أو الابتكار، سواء من داخل الوحدة أو من خارجها.

- إذا تبين للجنة أن الاختراع أو الابتكار يتعلق بالشئون العسكرية لا يجوز لها تقدير التعويض العادل، ويقتصر دورها على إحالة الموضوع بكامله للجهات المختصة في هذا

(1) نصت المادة(ع ع) من قانون الخدمة المدنية رقما1 لسنة 7 ( • بم، على الأحكام المتعلقة بمنح مكافاة

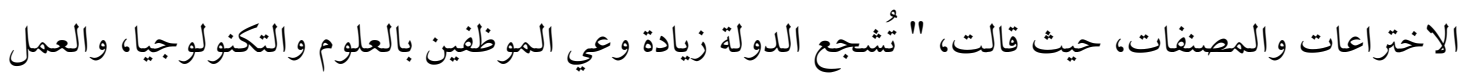
على نشر المعارف بينهم، وتطوير القدرات الابتكارية. وتكون الاختراعات والمصنفات التي يبتكرها الموظف

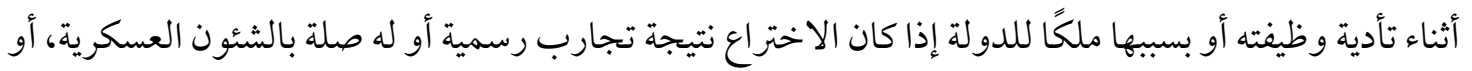
إذا كان الاختراع أو المصنف يدخل في نطاق أعمال الوظيفة. وفي جميع الأحوال يكون للموظف الحق في تعويض عادل، يُر اعى عند تقديره تشجيع البحث والاختراع. ويجوز أن يُنشأ صندوق خاص في الوحدة، تتكون موارده من حصيلة استغلال حق هذه الاختراعات والمصنفات، ويكون الصرف من حصيلة هذا الصندوق طبقًا للائحة المالية التي تضعها السلطة المختصة ". 


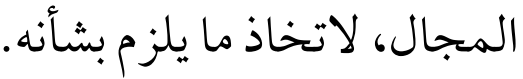

- وبعد تعويض الموظف تعويضا عادلاً عن عمله هذا، يكون الابتكار أو الاختراع ملكَّ للدولة في كل الأحوال، سواء كان متعلقًا بالشئون العسكرية، أو لم يكن. - يمكن أن يُشأ صندوق خاص في الوحدة التي بها الموظف المخترع، تتكون موارده من حصيلة استغلال حق هذه الاختراعات والمصنفات، ويجب أن تدرج موارده في الموازنة العامة للدولة ويكون الصرف من حصيلة هذا الصندوق طبقًا للائحة المالية التي تضعها السلطة المختصة من وزارة المالية). هذه هي أهم المكافآت التي قررها نظام الخدمة المدنية ولائحته التنفيذية، استهدف بها المشرع إثارة روح الإبداع والابتكار لدى الموظف العام، وتنمية قدراته و محاولة الوقوف على كل ما هو جديد من عالم التكنولوجيا لتطوير أدائه وإبداعاته في ممارسة مهام منصبه. ونخلص من كل ما سبق ذكره في هذا الفرع، إلى أن الأجور الحافزة تتكون من نوعين الموارد، الأولى مادية، وهي ـ كما سبق ذكره ـ الأجر والعلاوات والمكافآت التي قررتها القوانين واللوائح المنظمة لشئون الوظيفة العامة في الأنظمة المختلفة، ولا يتوقف الأمر على ذلك، بل تشتمل الأجور الحافزة على نوع آخر من الموارد، وهي الموارد غير المالية، وهي التي ستكون محل البحث في الصفحات التالية. = المكونات غير المالية للأجور الحافزة:- تشتمل الأجور الحافزة على مجموعة من

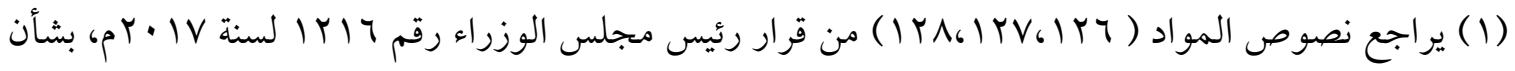
اللائحة التنفيذية لقانون الخدمة المدنية المصري الحالي رقم اي لسنة 7 أ بم. 
الموارد غير المالية، تعد مميزات يتمتع بها الموظف أثناء وبعد ممارسته لأعمال وظيفته، ولا شك في أن هذه الموارد أو المزايا لها دور كبير في تحقيق رضاه عن وظيفته، ومن ثم ممارسته لو اجباته الوظيفية بكفاءة وتميز.

وقد عرضنا في الصفحات السابقة للمكونات المالية للأجور الحافزة، والتي تتمثل أساسكا فيما يحصل عليه الموظف نقداً من مرتبات وعلاوات ومكافآت تشجيعية نظير ما قام به من جهود بدنية وذهنية عادية وغير عادية . ونشير في الصفحات التالية إلى المكونات ذات التأثير الإيجابي على معنويات الموظفين - وإن كان لبعضها قيمة مالية كالترقية- ولكنها تتميز بطابعها الإنساني والاجتماعي، وتأثيرها المباشر والفعال في رفع الروح المعنوية للموظفين ، لذا أطلق عليها الحوافز المعنوية . ت الم ولهذه الحوافز (المكونات غير المالية للأجور الحافزة) في التطبيق الإداري عدة صور ، منها الترقية، والإجازات، والرعاية الصحية والاجتماعية للموظفين .

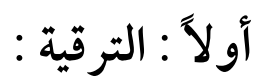

نحن أن قوانين التوظف المصرية قد أخذت بالنظرة الأوروبية للوظيفة العامة، تلكم النظرة التي تبنى فيها النظام الأوروبي النظرية الشخصية في ترتيب الوظائف العامة، ومن ثم اعتبرت الوظيفة العامة في ظل هذا النظام مهنة دائمة ينخرط فيها الموظف ويرتبط بها طيلة حياته الوظيفية، ويخصص لها كل نشاطه ووقته وجهده حتى بلوغه السن القانوني، مما يكسبه المهارة والخبرة التي تبرر تدرجه وترقيته في درجات السلم الوظيفي بما يتفق 


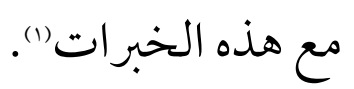

والترقية تعني شغل الموظف المُرقى لوظيفة أخرى ذات مستوى أعلى من الصعوبة والمسئولية والسلطة والمركز، تفوق مستوى وظيفته الحالية("). وتنطوي الترقية على ميزتين هامتين بالنسبة للموظف :

د. عمر حلمي : مبدأ الجدارة في تولية الوظائف العامة صVعا وما بعدها - د/ عبدالعظيم عبدالسلام :

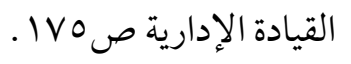

(Y) د. نبيل رسلان : الحوافز في قوانين الحكومة والقطاع العام •ط / دار النهضة العربية · القاهرة 9V1 ام $.1 \leqslant 9$

وهناك عدة تعريفات للترقية ، وإن كانت تختلف من حيث الألفاظ ، إلا أنها تدور حول معنيين رئيسيين، الأول: أن الترقية كما تكون من وظيفة إلى أخرى تكون أيضًا من درجة إلى أخرى أعلى منها، والمعنى الثاني : يرى أن

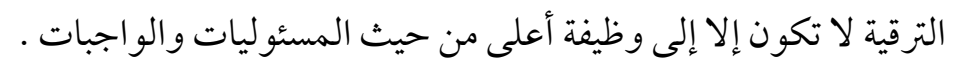

ير اجع في هذه التعريفات : د. محمد أنس جعفر : نظم الترقية في الوظيفة العامة ص •r و وما بعدها - د. عدلي خليل

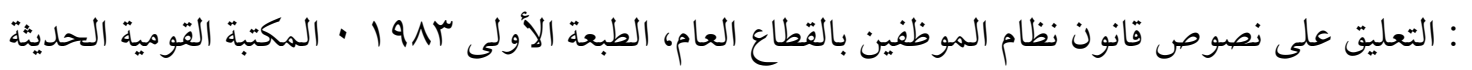
ص IVY - د. محمود حلمي مصطفى : نظام الموظفين المدنيين بالجهاز الإداري والقطاع العام ، الطبعة

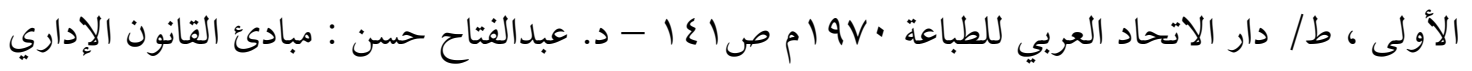

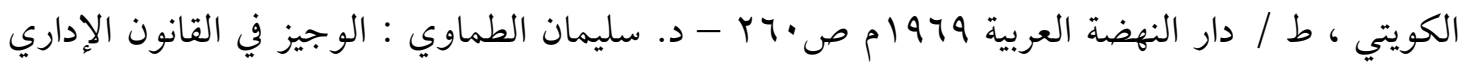
صع 0ع - د. محمد فؤاد مهنا : مبادئ وأحكام القانون الإداري، مطبعة الشاعر ، بدون تاريخ صع • •7 ، وقد عرفت المحكمة الإدارية العليا الترقية بأنها ما يطرأ على الموظف من تغيير في مركزه القانوني يكون من شأنه

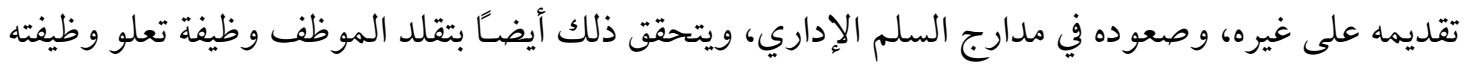
الحالية في مجال الاختصاص، وإن لم يصاحب هذا التقليد نفع مادي. المحكمة الإدارية العليا، طعن رقم

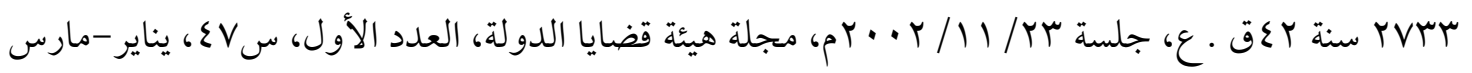

$$
\text { rlaspror }
$$


الميزة الأولى : التقدير الأدبي للموظف المُرقى، حيث تنقله الترقية من وظيفة إلى ألى

$$
\text { وظيفة أخرى أعلى منها في المستوى . }
$$

الميزة الثانية: مالية، حيث يحصل الموظف المرقى على الراتب المربوط لهذه

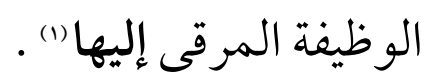

وتعد الميزة الثانية(المالية) محط أنظار الكثيرين من الموظفين؛ نظراً لاجتياح الظروف الاقتصادية السيئة لكثير من دول العالم -خاصة دول العالم الثالث- مما دفع معظم الموظفين إلى التفكير في الفروق المالية التي سيأتي بها المنصب الجديد، ناسين أو متناسين المركز الأدبي له، وأن هذا المنصب ذات مسئوليات وواجبات أعظم، قد بـ

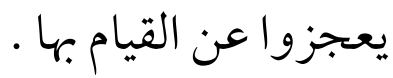

وتعمل الترقية في ظل هذا النظام (النظام الأوروبي) والتي أخذت به مصر على تحقيق اجتذاب أفضل العناصر البشرية وبقائهم في الخدمة المدنية، والوصول إلى أعلى معدل لرضاهم الوظيفي، وتوطيد الحافز في نفوس الموظفين أملاً في الفوز بها، زيادة

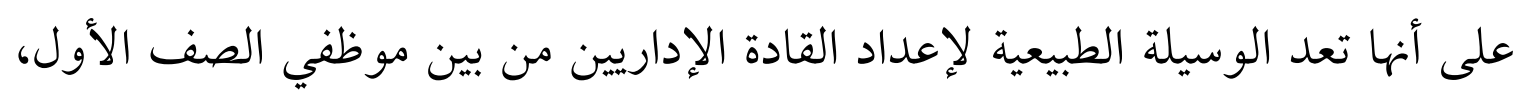
فضلاً عن أنها تعمل كذلك على سيادة روح الطاعة والنظام باعتبار أن الترقية هي وسيلة الرؤساء عن طريق الترغيب، وأن التأديب هو وسيلة الضغط و الترهيب(").

ولكي تحقق الترقية الأهداف المرجوة منها لابد أن تقوم على أسس صالحة

(1) د. السيد خليل هيكل : القانون الإداري السعودي ، الطبعة الأول ع99 ام ، مطابع جامعة الملك سعود صivi

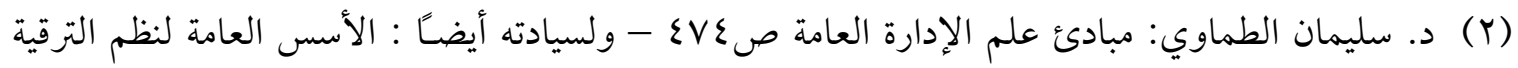

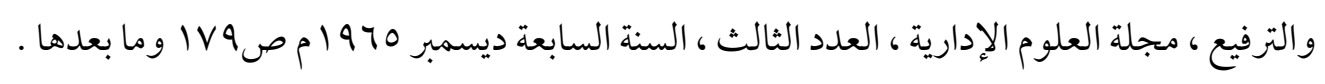


ومعايير واضحة تقضي بإبعاد الوساطة والمحسوبية عن مجال الترقية، وإلا أهدرَتَ

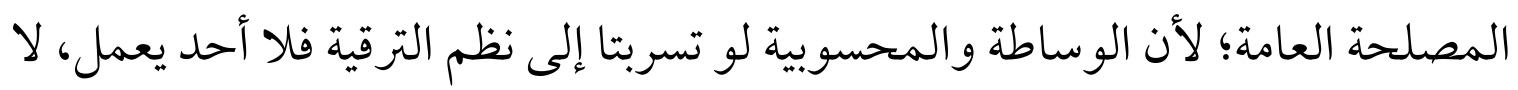

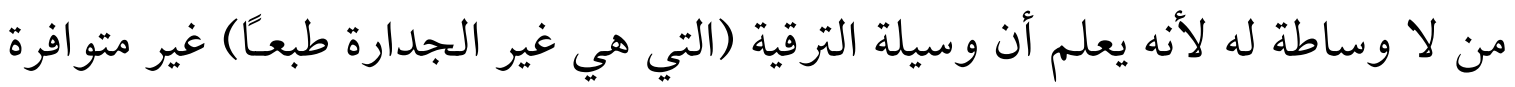

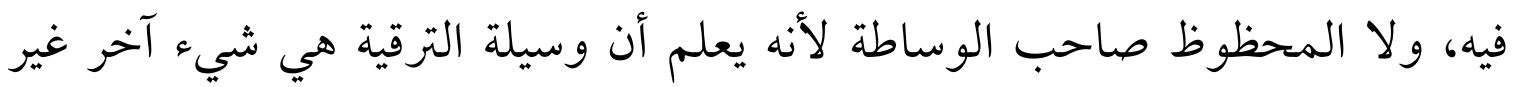

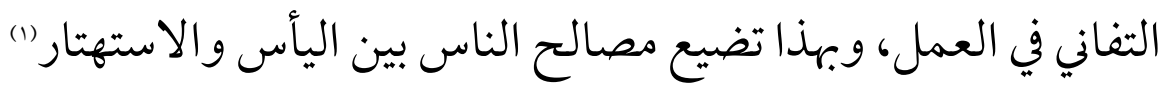
وتعتبر الترقية من أهم الدعامات التي تقوم عليها سياسة نظم التوظف التي تعتبر الوظيفة العامة مهنة دائمة ينقطع لها الموظف ، ويقضي في فيها طيلة حياته، كما أنها تعتبر من أهم العوامل في حياة الموظف، إن لم تكن أهم عامل على الإطلاق بعد عامل المرتب وأخطر منه، لأنها ترفع المرتب من ناحية وتصعد بالموظف في السلم الإداري

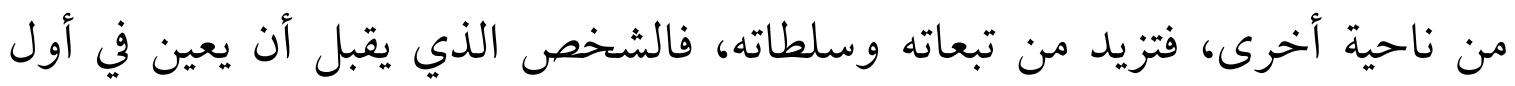

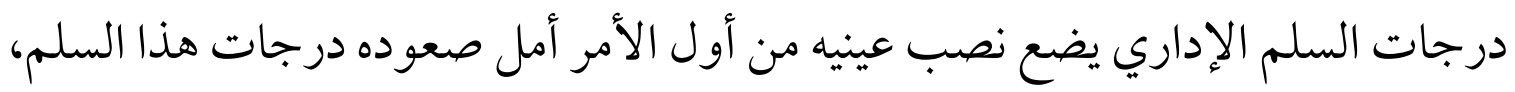

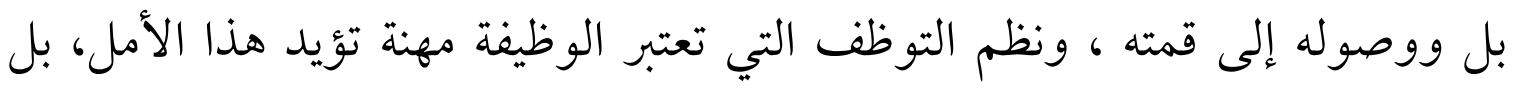

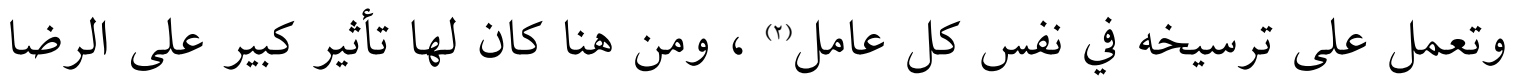
الوظيفي للموظف العام.

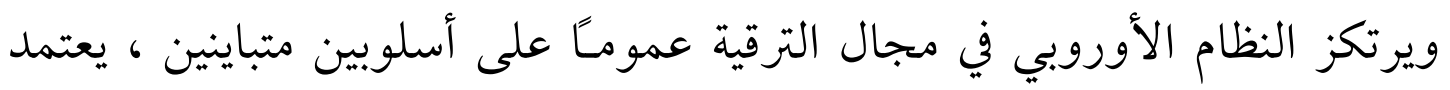

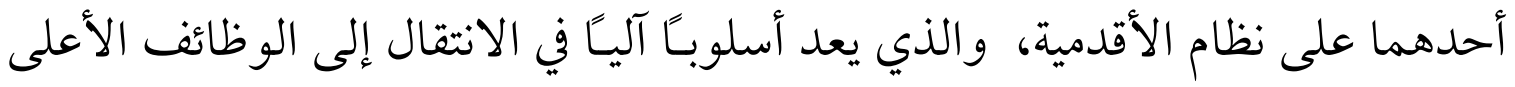
الشاغرة من بين أقدم الموظفين في الوظيفة الأدنى، بينما يقوم الآخر على نظام الاختيار

(1) د. نبيل رسلان : الحوافز في قوانين الموظفين بالحكومة والقطاع العام ص^ع| - دـ سليمان الطماوي:

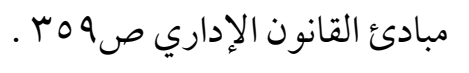

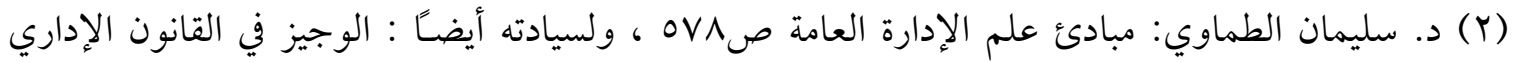

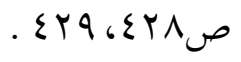




\section{وفق قو اعد وضو ابط معينة تضمن ترقية الأصلح للوظيفة الأعلى.}

ودون دخول في التفاصيل الدقيقة لهذين النظامين(") ، نود القول أن قانون الخدمة المدنية المصري الحالي رقم ا1 لسنة 7 أ بام، ومن قبله قوانين التوظف المصرية، قد أخذ بهما في مجال الترقية، فالترقية في الوظيفة العامة طبقا لقانون الخدمة المدنية الحالي تأخذ -وبنسب متفاوتة- بكل من الأقدمية والاختيار كأساسين للترقية في الدرجات الدنيا، مع الأخذ بالترقية بالاختيار للكفاية بالنسبة للدرجات العليا.

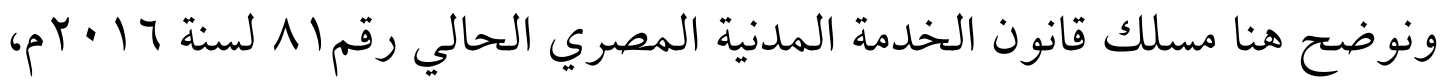
ولائحته التنفيذية، في الأخذ بالأقدمية والاختيار ونظام المسابقات كأساس للترقية للوظيفة الأعلى الشاغرة.

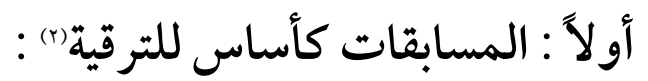
يقصد بالمسابقات " أن تقوم هيئة ما (قد تكون هيئة مركزية يحددها القانون أو الجهة التي يراد التعيين فيها ) بعقد امتحانات ذات طبيعة خاصة للمرشحين لشغل

(1) راجع مؤلفنا، النظم التقدمية في الوظيفة العمومية، دراسة مقارنة بين النظم الوضعية والشريعة الإسلامية، دار

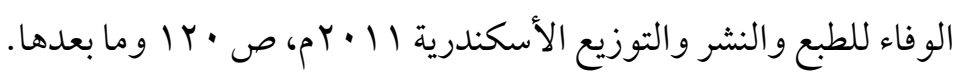

(Y) عرفت المسابقات بعدة تعريفات تدور كلها تقريبً حول معنيين ، الأول تقليص حرية الإدارة في الاختيار للوظائف العامة، ومن ثم محاولة القضاء على نظام المحاباة أو المحسوبية عند شغل الوظائف العامة، والمعنى الثاني : تحقيق نظام الجدارة ، بالثثبت من مدى صلاحية الشخص وقدرته على تحمل أعباء الوظيفة العامة . يراجع في هذه التعريفات : د. حمدي أمين عبدالهادي : نظرية الكفاية في الوظيفة العامة ، رسالته السابق الإشارة

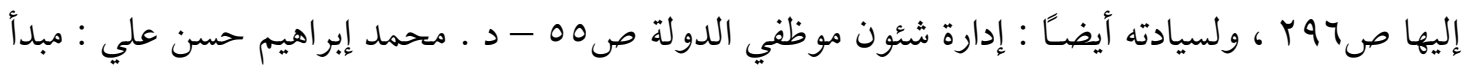
المساواة في تقلد الوظائف العامة دراسة مقارنة ، رسالة دكتوراه مقدمة لحقوق القاهرة عه9191910 ام ص9 • ا - الأستاذ / Alain Plantey بحث عملي في الوظيفة العامة ، أشار إليه د. محمد إبراهيم حسن :

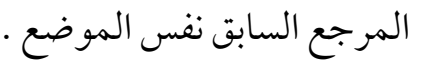


الوظائف العامة بقصد التحقق من كفايتهم وصلاحيتهم لتحمل أعباء وحاجيات الوظائف، على أن يرتب الناجحون في كشوف طبقـَ لترتيب نجاحهم في المسابقة، على أن يتم التعيين وفقًا لهذا الترتيب " (1)

فنظام المسابقة يمثل قيداً على حرية الإدارة في الاختيار للوظيفة العامة، بما يفرضه عليها من الالتزام بالترتيب الوارد في كشوف الناجحين عند التعيين، والتي أسفرت عنه نتيجة المسابقة، ومن ثم غلق الباب تمامـًا أمام جهة الإدارة في إعمال نظام الوساطة والمحسوبية في مجال التوظيف. وقد أشار الجدول رقم(1) المرفق بقانون الخدمة المدنية المصري الحالي الخاص بالوظائف التخصصية، إلى الوظائف التي تشغل بهذا الأسلوب، وهي التي تحمل

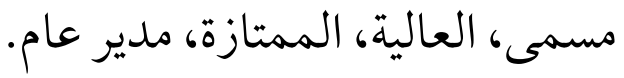
وقد نظم شغل هذه الوظائف طبقَّ لهذا الأسلوب القانون رقم ه لسنة (991 (م) بشأن الوظائف القيادية المدنية في الجهاز الإداري والقطاع العام، ولائحته التنفيذية.

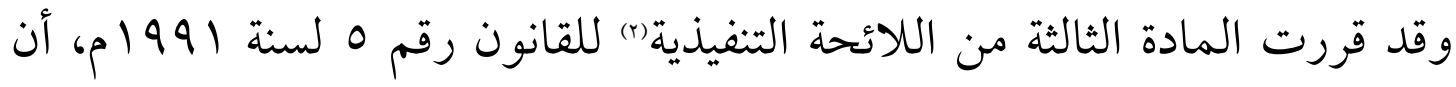
شغل الوظائف العامة القيادية يكون عن طريق الإعلان في صحيفتين يوميتين واسعتي الانتشار، أو في لوحة الإعلان داخل الوحدة، وذلك إذا قررت السلطة المختصة بالتعيين شغل تلك الوظائف من بين الموظفين بالو حدة .

(1) د. محمد السيد الدماصي: تولية الوظائف العامة ، رسالته السابق الإشارة إليها صه ـr ـ. (Y) صدرت اللائحة التنفيذية للقانون رقم ه لسنة ا99 ام بقرار رئيس مجلس الوزراء رقم 1997 لسنة 1991

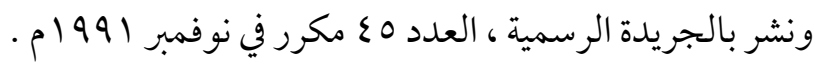


ويتضح من ذلك أن شغل الوظائف المدنية القيادية يكون عن طريق مسابقة مفتوحة يتقدم لها كل من تتوافر فيه شروط التأهيل لتولي هذه الوظائف، سواء كان من داخل الوحدة أو خار جها (وهذا هو الأصل بناءً على هذه المادة)، وعلى ذلك قد يظفر بالترقية إلى هذه الوظائف واحد من خارج من الوحدة الإدارية ما دام قد تقدم على غيره في المسابقة، أو عن طريق المسابقة المغلقة، وهي التي تُصر التقدم للمسابقة على الموظفين بالو حدة دون غيرهم، ومن ثم سيظفر بالترقية واحد من بينهم.

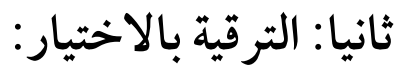
كانت الإدارة قديمًا تتمتع بسلطات واسعة في الترقية بالاختيار، وكان يطلق على الاختيار آنذاك، الاختيار الحر، لكن بعد ظهور قوانين التوظف وتحيقًا لمبدأ تكافأ الفرص، أصبحت الترقية بالاختيار لها ضوابط وشروط يجب توافرها في الموظف المرقى، وقد قيدت سلطة الإدارة في الاختيار طبقَّ للوائح والقوانين. والوظائف التي تشغل بهذا الأسلوب، هي وظائف الدرجة الأولى (أ)، وذلك طبقًا للجدول رقم(1) المرفق بقانون الخدمة المدنية الحالي، وطبقًا أيضًا لنص المادة (Yq) من ذات القانون، حيث نصت، " ... وتكون الترقية للوظائف التخصصية من المستوى الأول (ب) بالاختيار على أساس بيانات تقويم الأداء وما ورد في ملف الخدمة من عناصر الامتياز.... ". وقد اشترطت المادة (19) من اللائحة التنفيذية لقانون الخدمة المدنية في الموظف المراد ترقيته بالاختيار ضرورة حصوله على تقدير ممتاز في العاميين السابقين مباشرة على سنة الترقية، واحتيازه بنجاح التدريب التي تتيحه له الوحدة الإدارية. ثالثًا: الترقية بين الأقدمية والاختيار في قانون الخدمة المدنية المصري الحالي: قيما عدا الوظائف التخصصية السابقة التي تشغل بنظام المسابقة، والتي تشغل 
بالاختيار بنسبة مائة بالمائة ـ كما سبق _ـ، أخذ قانون الخدمة المدنية بنظام مزدوج وهو الجمع بين الترقية بالأقدمية، والترقية بالاختيار بنسب متفاوتة تزيد فيها نسبة الترقية بالاختيار كلما ارتقينا إلى أعلى في درجات السلم الإداري، والعكس، حيث تزيد نسبة الترقية بالأقدمية كلما نزلنا على درجات السلم الإداري.

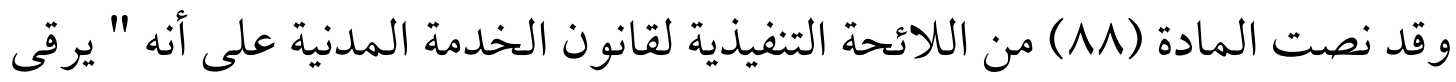
شاغلو الوظائف التخصصية بالاختيار في حدود النسب المبينة قرين كل مستوى مرقى

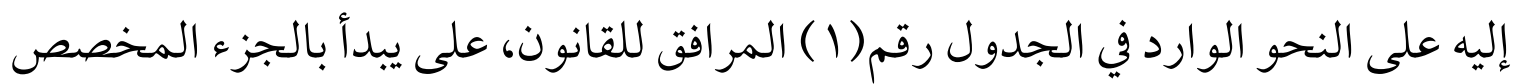

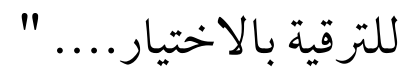
وطبقً للجدول رقم (1) المرفق بهذا القانون، تتم الترقية بالاختيار والأقدمية بالنسبة للوظائف التخصصية في حدود النسب الآتية :-

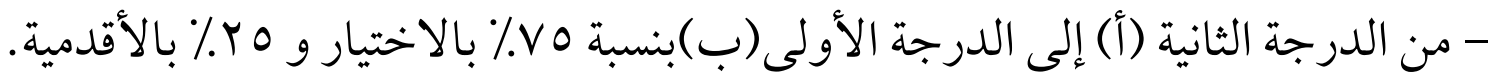
- من الدرجة الثانية (ب) إلى الدرجة الثانية (أ) بنسبة • 0\%بالاختيارو • 0\% بالأقدمية. - من الدرجة الثالثة (أ) إلى الدرجة الثانية (ب) بنسبة • ع. بالاختيار و • جـ بالأقدمية.

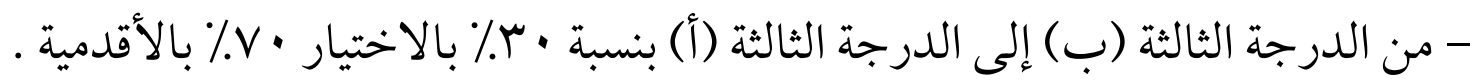

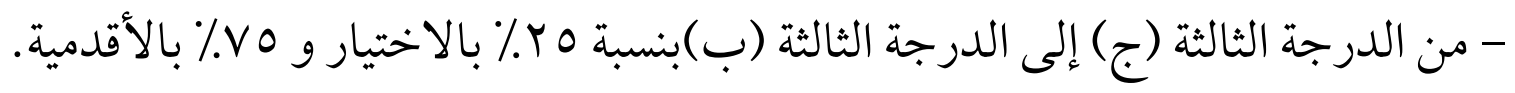
ويلاحظ أن نسبة الترقية بالاختيار للكفاية تكون ضئيلة في أدنى درجات السلم الإداري، ثم تتصاعد شيئً فشيئً بنسب متفاوتة إلى أن تصل نسبة . . 1\% إلى الدرجة

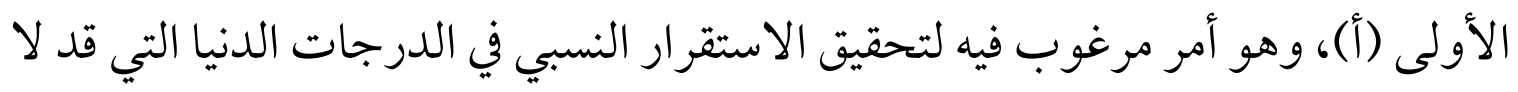
تتطلب قدرات خاصة والتي تعمل على تحقيقه الأقدمية هذا من ناحية ، ولإتاحة الفرصة للموظفين الممتازين أصحاب المهارات العالية والقدرات الخاصة لشغل 
الدرجات العليا من ناحية أخرى، بشرط أن يتم كل ذلك بموضوعية وبلا تعسف وفي

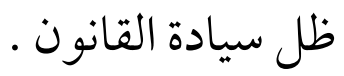
وقد بيّن قانون الخدمة المدنية ولائحتة التنفيذية شروط وضوابط الترقية بشكل عام، فقد تضمنت المادة (19) من اللائحة التنفيذية شروط الترقية بالاختيار، كالتالي:1 - أن يحصل الموظف على تقرير تقويم أداء بمرتبة ممثاز في السنتين السابقتين مباشرة

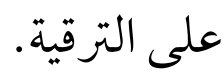

ץ- إذا كان عدد الحاصلين على تقدير ممتاز أقل من العدد المطلوب للترقية، يتم تكملت العدد من الحاصلين على تقدير كفء على الأقل عن ذات المدة. r- إذا لم يكف عدد الحاصلين على تقدير كفء، تؤجل الترقية وتحجز الوظائف في الجزء المتبقي إلى أول ترقية تالية. ع - يجب على الموظف المراد ترقيه بالاختيار أن يجتاز بنجاح التدريب الذي تعد له

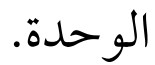
والمادة (•r) من قانون الخدمة المدنية وضحت معايير المفاضلة بين الموظفين المتقدمين للترقية بالاختيار في حالة تنافسهم عليها، أو في حالة تساويهم في مرتبة تقدير تقويم الأداء في السنتين السابقتين على الترقية، وذلك وفقـا للضو ابط التالية:1- في حالة المنافسة على الترقية، يفضل الموظف الحاصل على مجموع درجات أعلى الى الى في تقويم أداء السنتين السابقتين مباشرة على الترقية. r- عند التساوي في مجموع درجات السابقتين، يفضل الأعلى في مجموع درجات تقويم أداء السنة السابقة عليهما. r- عند التساوي في الحالتين السابقتين، يفضل الموظف الحاصل على درجة علمية 
أعلى إذا كانت متصلة بطبيعة العمل، متى كانت متصلة بطبيعة العمل طبقًا لما تقرره السلطة المختصة بناءً على اقتراح لجنة الموارد البشرية. ع - عند التساوي في الدرجة العلمية، يفضل الحاصل الأعلى في التقدير العام لهذه

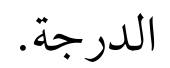
0- وعند التساوي فيما سبق، يفضل الأقدم في المستوى الوظيفي المرقى منه"). وقد اشترطت المادة (•9) من نفس اللائحة للترقية بالأقدمية، حصول الموظف على لق تقرير تقويم أداء بمرتبة كفء على الأقل في السنتين السابقتين مباشرة على الترقية. والملاحظ هنا أن المشرع قد اشترط في حالة الترقية بالاختيار النجاح في التدريب الذي تتيحه له الوحدة الإدارية طبقَّ للمادة (9)) من اللائحة التنفيذية، دون أن يذكر هذا الشرط في الترقية بالأقدمية، طبقَّ للمادة ( 9 ) من نفس اللائحة سالفة الذكر، مما يوحي أنه لا يشترط نجاح الموظف في التدريب، أو حتى دخوله التدريب أصلاً في حالة ترقيته بالأقدمية .

ومن وجهة نظري، هذا مسلك يؤخذ على المشرع، حيث إننا نعلم أن الترقية سواء كانت بالأقدمية أو بالاختيار يترتب عليها شغل الموظف المرقى لوظيفة أعلى في

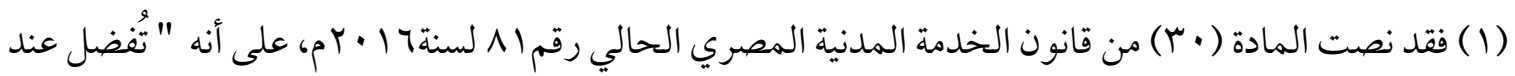
الترقية بالاختيار ترقية الأعلى في مجموع درجات تقويم أداء السنتين السابقتين مباشرة على الترقية، وعند

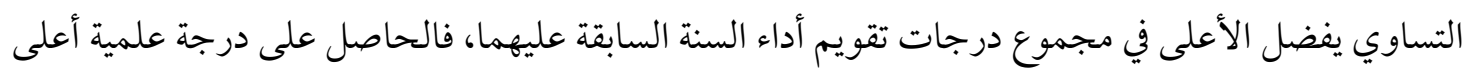
متى كانت متصلة بطبيعة العمل طبقًا لما تقرره السلطة المختصة بناءً على اقتراح لجنة الموارد البشرية، وعند التساوي يفضل الأعلى في التقدير العام لهذه الدرجة، فالأقدم في المستوى الوظيفي المرقى منه". 
درجات السلم الإداري ذات اختصاصات ومسئوليات أكثر أهمية، مما يتطلب كفاءات وقدرات في الموظف المرقى تتناسب مع هذه المسئوليات والاختصاصات الأكثر أهمية، لذا كان من الأحرى اشتراط هذا الشرط حتى عند الترقية بالأقدمية. أما عن الشروط العامة للترقية، سواء كانت بالاختيار أو بالأقدمية، وفقد تحدثت عنها المادة (19) من اللائحة التنفيذية لقانون الخدمة المدنية، حيث اشترطت للترقية

$$
\text { بشكل عام عدة شروط من أهمها:- }
$$

ا - أن تكون الترقية إلى وظيفة شاغرة وممولة تلي مباشرة الوظيفة التي يشغلها الموظف في المستوى وفي ذات المجموعة الوظيفية التي تنتمي إليها. r- أن تتو افر في الموظف كافة الشروط المطلوبة لشغل الوظيفة المرقى إليها. ب- ضرورة مرور ثلاث سنوات على بقاء الموظف في الوظيفة المراقى منها قبل ترقيته للوظيفة الأعلى، وهي المدة البينية التي تطلبها المشرع في الجدول رقم( ( ) المرافق لقانون الخدمة المدنية ع - أن تكون الترقية بقرار من السلطة المختصة، أو ممن تفوضه في اصدار مثل هذه القرارات، بناءً على اقتراح لجنة الموارد البشرية.

ه- مراعاة النسبة الواردة في الجدول رقم(1) المرافق للقانون، فيما يتعلق بالترقية بالاختيار والترقية بالأقدمية). 7- وياستثاء جزاءي الإنذار والخصم من الأجر مدة لا تزيد على عشرة أيام، لا تجوز ترقية الموظف قبل محو الجزاء الموقع عليه(r). 
وقد حظرت اللائحة التنفيذية لقانون الخدمة المدنية النظر في ترقية أي من الموظفين ـ سواء كانت الترقية بالاختيار أو بالأقدمية ــ الذين تتوافر فيهم حالة من الحالات

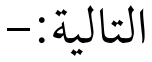

$$
\text { 1 - إذا كان معاراً، إلا بعد عودته من الإعارة. }
$$

r- إذا كان حاصلاً على إجازة بدون أجر، إلا بعد عودته من الإجازة، باستثناء الإجازة

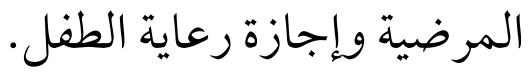
ץ- إذا وقع عليه جزاء الخصم من الأجر لمدة تزيد على عشرة أيام، أو جزاءً أشد من ذلك قبل محو الجزاء الموقع عليه. ع - إذا كان محالاً إلى المحاكمة التأديبية أو الجنائية أو موقوفتًاعن العمل، وذلك طول مدة الإحالة أو الوقف. ولا يجوز في هذه الحالة تأخير ترقية الموظف لمدة تزيد على سنتين.

وقد سبق لنا القول بأن الترقية تحقق ميزتين، الأولى: معنوية أو أدبية وهي الارتقاء بالموظف درجة أعلى في درجات السلم الإداري ذات مسؤوليات أكبر، أما الميزة الأخرى: مالية أو مادية، وتتمثل في زيادة راتبه بما يتناسب مع المسؤوليات الأعباء الجديدة، وقد تحدثت عن هذه الميزة المادة (آr) من قانون الخدمة المدنية، حيث قررت يمنح الموظف منذ صدور قرار ترقيته، الأجر الوظيفي المقرر للوظيفة المرقى إليها، أو أجر وظيفته السابقة مضافًَا إليه (ه\%) من هذا الأجر، أيهما أكبر (1).

(1) فقد نصت المادة (1/r) على أنه " يصدر قرار الترقية من السلطة المختصة، وتعتبر الترقية نافذة من تاريخ

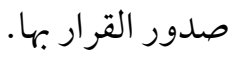


ونظراً لما تنطوي عليه الترقية من مزايا أدبية ومادية، فإن لها تأثير كبير على رضاه

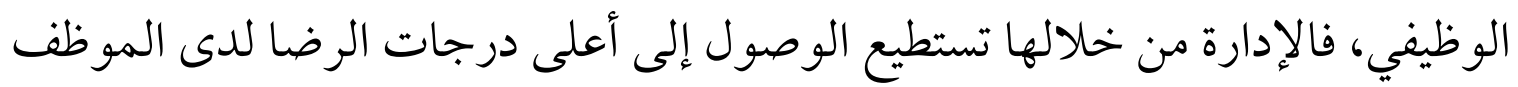
العام.

$$
\text { ثانيسًا : الإجازات : (1) }
$$

والإجازة تعني : تغيّب مشروع عن العمل سواء كان بأجر أو بغير أجر (1) .

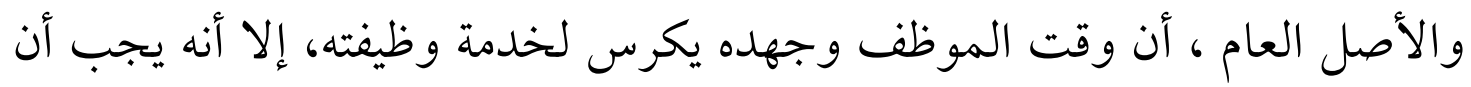
تكون هناك فترات يخلد فيها الموظف إلى الراحة لتجديد واستعادة نشاطه مرة أخرى . وإذا كانت الإجازات التي يحصل عليها الموظف تعتبر امتيازاً له ولمصلحته، إلا أن الهدف منها هو حماية صحة الموظف وتجديد نشاطه الذهني والفكري، ومحافظة على استمرار إنتاجيته بكفاءة واقتدار ، لأن فترة الراحة -الإجازة- نشاط للموظف (). وما دام الغرض من الإجازة هو إعطاء الموظف قسطكّ من الراحة لاستعادة وتجديد

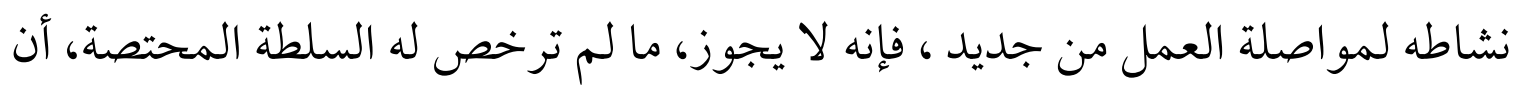

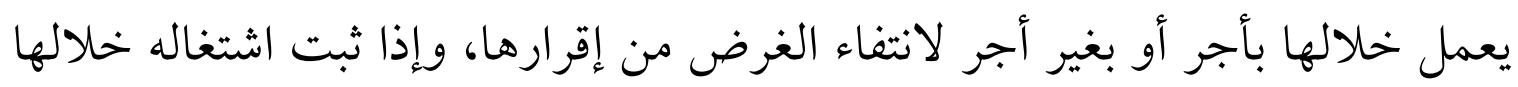
لحساب جهة أخرى كان للجهة التي يتبعها -مانحة الإجازة- أن تحرمه من أجره عن إنري مدة الإجازة، وتسترد ما كانت قد دفعته له من أجر ، مع الاحتفاظ لها في جميع الأحوال

ويستحق الموظف اعتبارًا من هذا التاريخ الأجر الوظيفي المقرر للوظيفة المرقى إليها أو أجره السابق مضافًا إليه

$$
\text { علاوة ترقية بنسبة (0) من هذا الأجر الوظيفي أيهما أكبر". }
$$

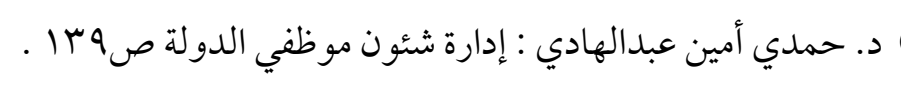

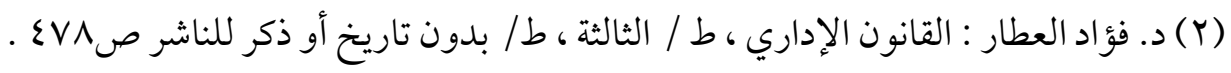




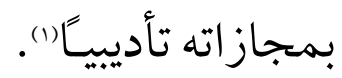

\section{ولإججازات في الواقع الإداري عدة صور (r) نوضحها فيما يلي :

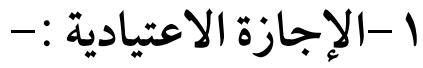

وهي إجازات تعطى للموظفين بصفة دورية سنويًا، وهي شرعت لراحتهم

واستعادة نشاطهم بعد ما بذلوه من جهد على مدار العام فيما أسند إليهم من أعمال .

وقد تكون هذه الإجازات موحدة بالنسبة لجميع الموظفين، وقد تتفاوت طولاً

وقصراً حسب سن الموظف، أو مدة خدمته، أو مستو اه الوظيفي .

كما يمكن تجزئتها أو إرجاء منحها، بل يمكن منعها وقطعها بعد منحها لأسباب قومية يقتضيها صالح العمل، ويجب لتمتع الموظف بها مو افقة رئيسه مقدمًا عليها بناءً على طلب منه.

ويدخل في نطاق هذه الإجازات ، الإجازات المقررة للموظفين في المناسبات الدينية والوطنية.

وقد نظم قانون الخدمة المدنية المصري الحالي رقم ا ل لسنة 7 ا • بم هذه النوعية

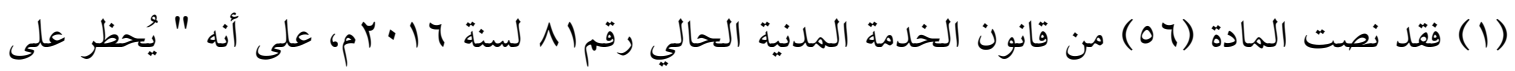
الموظف أن يؤدي عملاً للغير بأجر أو بدون أجر خلال مدة الإجازة بغير ترخيص من السلطة المختصة، وإلالا

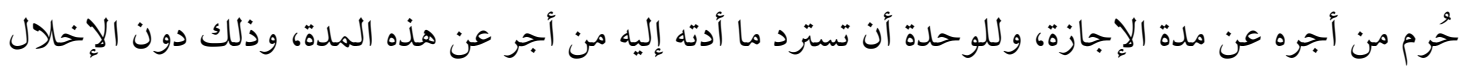

$$
\text { بالمسئولية التأديبية ". }
$$

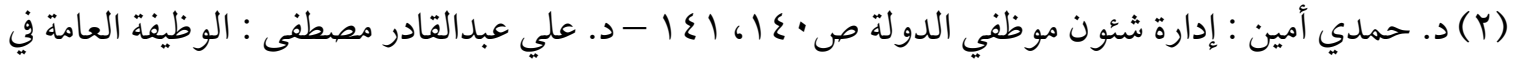
النظام الإسلامي وفي النظم الحديثة صهو وما بعدها - د. سليمان الطماوي : الوجيز في القانون الإداري

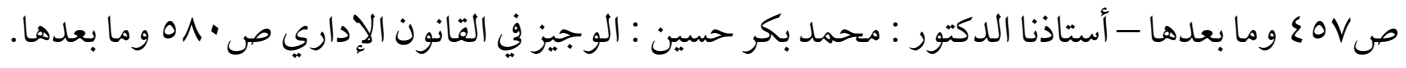




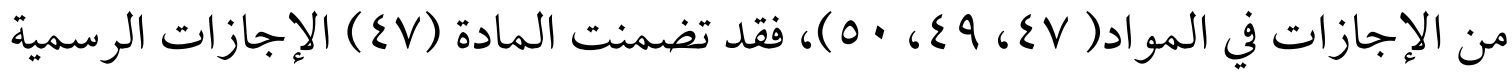
التي تمنح للموظفين في الأعياد والمناسبات الوطنية بأجر كامل، وفي حالة تشغيله خلال هذه الإجازات -عند الضرورة- يضاعف له أجره ، أو يعوض عنها"(') كما تضمنت المادة (9 ع) الأحكام الخاصة بالإجازة السنوية أو الاعتيادية أو الدورية للموظفين، ونجمل الأحكام الخاصة بها فيما يلي :أ-مدة الإجازة الدورية)

$$
\text { تتفاوت مدة هذه الإجازة على النحو التالي :- }
$$

10 يومـا في السنة الأولى من خدمة الموظف بعد مضي ستة اشهر من تاريخ

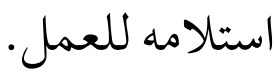

$$
\text { ا Y يومَا لمن أتم سنة كاملة في الخدمة. }
$$$$
\text { • س يومَّا لمن أمضى في الخدمة عشر سنوات . }
$$$$
\text { ○ يو مَّا لمن تجاوز عمره الخمسين سنة . }
$$

(1) فقد نصت المادة (\&V) من قانون الخدمة المدنية على أنه " يستحق الموظف إجازة بأجر كامل عن أيام عطلات الأعياد والمناسبات الرسمية التي تحدد بقرار من رئيس مجلس الوزراء، ويجوز تشغيل الموظف في

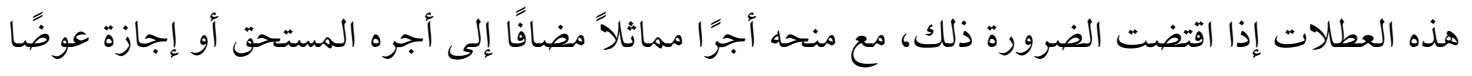
عنها. وتسري بالنسبة للأعياد الدينية لغير المسلمين أحكام قرار رئيس مجلس الوزراء الصادر في هذا الشأن ".

(Y) وهذه الإجازة وجوبية ، والوجوب يشمل الموظف والجهة التي يعمل بها ، بمعنى أنه من حق الموظف أن يطالب بها، ومن واجب الإدارة أن تستجيب دون أن تترخص في منحه هذه الإجازة إلا لأسباب قومية تقتضيها مصلحة العمل . 
ويمنح الموظفون من ذوي الإعاقة إجازة سنوية لمدة خمسة وأربعون يومًا دون التقيد بعدد سنو ات الخدمة.

\section{ب-بور السلطة المختصة :--}

أجاز القانون للسلطة المختصة زيادة مدة الإجازة الاعتيادية بما لا يجاوز خمسة

عشر يومَّا لطائفتين من العمال :

الأولى : العمال الذين يعملون في مناطق نائية .

الثانية: العمال الذين يعملون في أحد فروع الوحدة الإدارية خارج الجمهورية .

وتمنح هذه الإجازة سنويـًا للموظفين بأجر كامل ولا تحسب من ضمنها الإجازات

الرسمية السابق الإشارة إليها في المادة (\&V)، ولا يجوز تقصيرها، أو تأجيلها،

أو إنهاؤها، إلا أسباب قومية تقتضيها مصلحة (1).

جـ- السماح بتر اكم رصيد الإجازة الاعتيادية :

تعتبر الإجازة الاعتيادية من حقوق الموظفين التي تقتضيها طبيعة العمل، ومن ثم لا

(1) يستحق الموظف إجازة اعتيادية سنوية بأجر كامل، لا يدخل في حسابها أيام عطلات الأعياد والمناسبات

$$
\begin{aligned}
& \text { الرسمية فيما عدا العطلات الأسبوعية، وذلك على الوجه الآتي: } \\
& 1 \text { - } 10 \text { يومًا في السنة الأولى، وذلك بعد مضي ستة أشهر من تاريخ استلام العمل. } \\
& \text { r - ا Y يومًا لمن أمضى سنة كاملة في الخدمة. }
\end{aligned}
$$

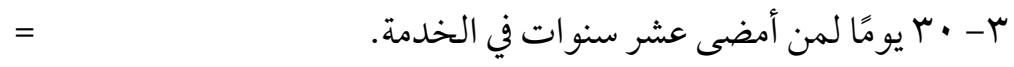

$$
\begin{aligned}
& \text { ع - م ي يومًا لمن تجاوزت سنه الخمسين. }
\end{aligned}
$$

ويستحق الموظف من ذوي الإعاقة إجازة اعتيادية سنوية مدتها خمسة وأربعون يومًا دون التقيد بعدد سنوات

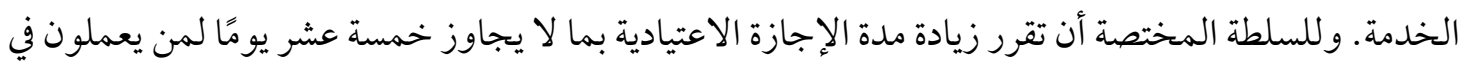

$$
\text { المناطق النائية، أو إذا كان العمل في أحد فروع الوحدة خارج الجمهورية. }
$$

ولا يجوز تقصير أو تأجيل الإجازة الاعتيادية أو إنهاؤها إلا لأسباب قومية تقتضيها مصلحة العمل. 
يجوز تأجيلها أو تقصير ها أو إلغائها، إلا لأسباب ضرورية تقتضيها مصلحة العمل .

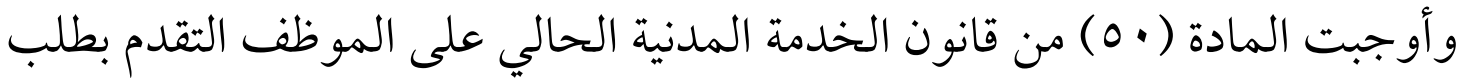
للحصول على كامل إجازته الاعتيادية، وإذا لم يتقدم بهذا الطلب سقط حقه فيها، ولا يستحق مقابلاً نقديًا عنها. وأما إذا تقدم بالطلب ورفضته السلطة المختصة، استحق مقابلاً نقديًا عنها يصرف بعد مرور ثلاث سنوات على انتهاء العام المستحق عنه الإجازة على أساس أجره

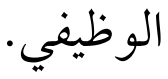
ولا يجوز للوحدة ترحيل هذه الإجازة إلا لأسباب تتعلق بمصلحة العمل، وفي حدود الثلث على الأكثر ولمدة لا تزيد على ثلاث سنوات، وذلك عند تقدم الموظف بطلب للحصول عليها ويتم رفض هذا الطلب").

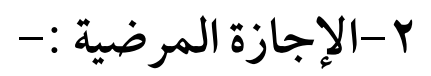

وهي التي تقرر لمو اجهة حالة مرض الموظف التي تعوق أدائه لمهام عمله، وتحدد مددها عن كل فترة زمنية معينة كثلاث سنو ات مثلاً، وهذه المدد قد تكون بأجر كامل أو

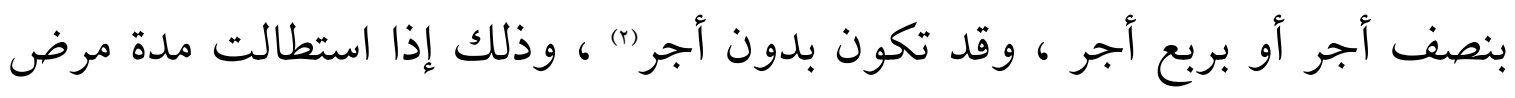
الموظف، وتقرر هذه الإجازة وتحدد مددها بناءعلى الكشف الطبي على الموظف من قِبَل جهة طبية معتمدة . وقد نظمت المادة (10) من قانون الخدمة المدنية المصري الحالي رقم 1 لسنة

(1) مادة (1) (1) من اللائحة التنفيذية لقانون الخدمة المدنية.

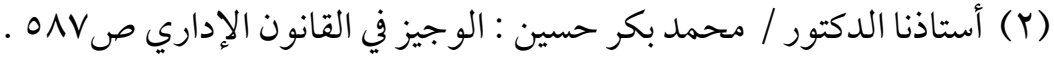




\section{1 • r م، ونشير إلى أهم الأحكام الخاصة بهذه الإجازة على النحو التالي :- \\ أ-لمن تستحق ؟ وما حدودها ؟}

تستحق للموظف كل ثلاث سنوات تقضى في الخدمة بقرار من المجلس الطبي

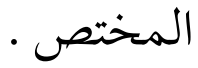

أما عن حدودها ، فقد راعى المشرع حالة الموظف المريض، فجعل أجره في الثلاثة أشهر الأولى من إجازته كاملاً، وفي الثلاثة أشهر التي تليها بما يعادل ه ٪٪ من أجره الوظيفي، وفي الستة أشهر التالية لها بما يعادل •0٪ من أجره الوظيفي، و \٪٪ من الأجر الوظيفي لمن يجاوز سنه الخمسين · وأجاز القانون للموظف الحق في مد هذه الإجازة بدون أجر للمدة التي يحددها المجلس الطبي المختص، إذا قرر احتمال برئه -شفائه-.

وفي جميع الأحو ال أعطى القانون الموظف الحق في طلب تحويل الإجازة المرضية

إجازة اعتيادية إذا سمح رصيده منها بذلك"(1).

$$
\text { تعليتق :- }
$$

الجميع يقدر مدى أهمية المرتب بالنسبة للموظف، حيث يعتبر مصدر دخله الوحيد -لدى الكثير من الموظفين - الذي يعتمد عليه في إشباع حاجاته وحاجات أسرته أو من يعولهم، فأكثر الأفراد، إن لم يكن جميعهم، أحد أهم أسباب التحاقهم بالوظيفة العامة هو تأمين حياة كريمة لهم ولمن يعولوا، خاصة في حالة عجزهم عن العمل أو انخفاض قدراتهم البدنية في الكسب الطيب الذي ينفقون منه على أنفسهم ومن يعولوا. 
فهل يعقل عندما تزداد أعباؤه بسبب تكاليف علاجه أن يحرم من مرتبه كله أو بعضه

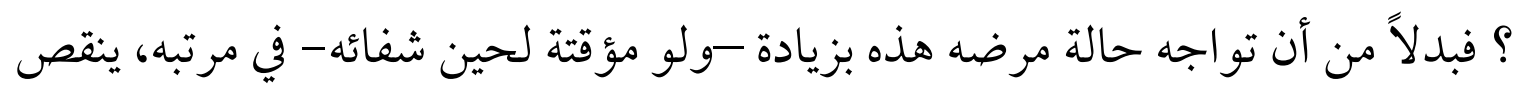
من أجره !!

لذا أرى صرف مرتب الموظف المريض كاملاً طو ال فترة علاجه حفاظكً على من

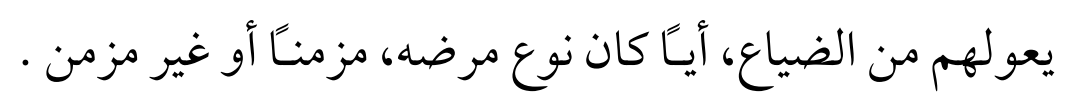

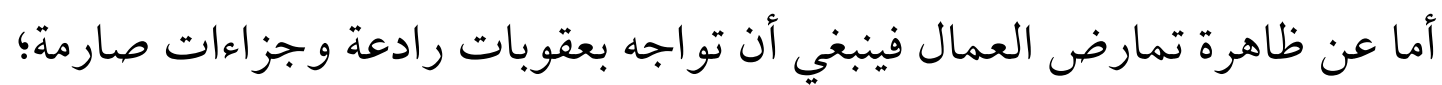
للقضاء عليها أو للحد منها، هذا فضلاً عن أنه في ظل التقدم الطبي الكبير في الآونة الأخيرة يندر معه ادعاء الشخص بمرض لم يكن مصابًا به . ب-حكم خاص بالمريض بمرض مزمن :-

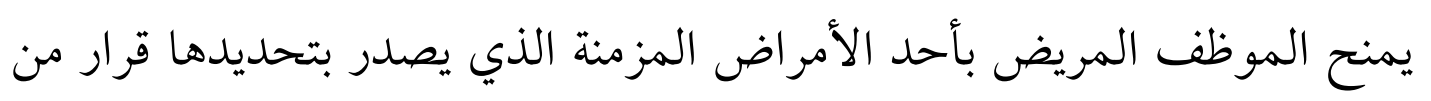
وزير الصحة بناءً على موافقة المجلس الطبي المحنص إجازة استثنائية بأجر كامل إلى بـ بهري

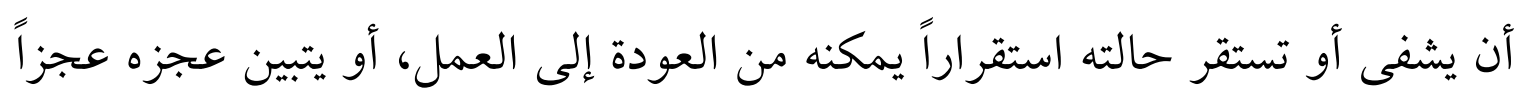
كاملاً، وفي هذه الحالة الأخيرة يظل الموظف في إجازة مرضية بأجر كامل حتى بلوغه لونه سن المعاش. وإذا رغب الموظف المريض في إنهاء إجازته والعودة إلى عمله، وجب عليه أن يقدم

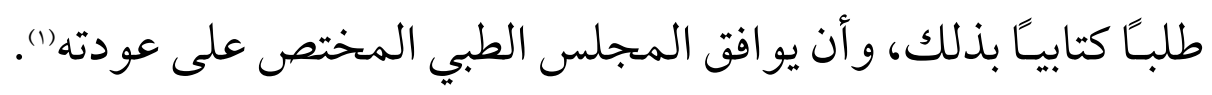
r-الإجازة العارضة :-

وهي إجازة تقتضيها ظروف قهرية طارئة تحتم على الموظف التغيب الفوري عن (1) المادة (10 ) من قانون الخدمة المدنية الحالي. 
العمل دون التمكن من إبلاغ الإدارة والحصول على مو افقتها، وهي فترة قصيرة نسبيً تحدد على مـدار العام، وتؤخذ مجزأة، وإذا مضى العام يسقط حقه فيها (1).

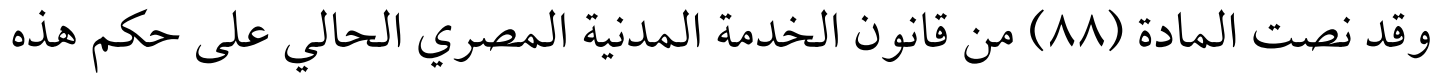
الإجازة فقالت : ": للموظف أن ينقطع عن العمل لسبب عارض لمدة لا تتجاوز سبعة أيام خلال السنة وبحد أقصى يومان في المرة الواحدة." ، فالموظف لا يجوز له أن يحصل على أكثر من يومين متتاليين باعتبارهما مدة كافية لمو اجهة الظروف الطارئة، لذا حق الموظف فيها ليس مطلقًا بل مقيداً بالظرف الطارئ .

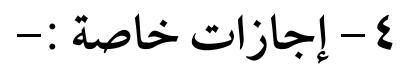

وهذه الإجازات تقتضيها اعتبارات إنسانية واجتماعية خاصة بالموظف، مثل إجازة الوضع أو الأمومة بالنسبة للمرأة الموظفة بمناسبة الولادة، وإجازة الحج التي تمنع بمناسبة أداء هذه الفريضة الدينية، والإجازات الخاصة التي تمنح لأحد الزوجين لمرافقة الآخر في الخارج حفاظًا على الروابط الأسرية، وهذه النوعية من الإجازات منها ما يكون بأجر ومنا ما يكون بدون أجر . مان. الإجازات الخاصة في قانون الخدمة المدنية المصري الحالي رقم /1 لسنة 1 ا • بم :وتنقسم هذه الإجازات إلى نوعين ، إجازات خاصة بأجر، وإجازات خاصة بدون أ- إجازات خاصة بأجر : أن وهذه النوعية من الإجازات قررها المشرع في حالات خاصة ورد النص عليها في 
المادة (Or) من قانون الموظفين الحالي على النحو التالي : - لأداء فريضة الحج وتكون لمدة شهر، وذلك لمرة واحدة طوال مدة خدمة الموظف الوظيفية، حيث إن هذه الشعيرة الإسلامية واجبة على المقتدر مرة واحدة في العمر طبقًا لتعاليم الإسلام الحنيف، ويقصد بالحج كما صرحت اللائحة التنفيذية، زيارة الأراضي المقدسة (مكة المكرمة والمدينة المنورة)، وزيارة بيت المقدس في فلسطين (1)، وهذا التفسير من اللائحة التنفيذية يتناسب فئات الموظفين التي يتكون منهم الجاز الإداري في الدولة، حيث يجمع بين المسلمين والمسيحيين، فلكل منهم وجهة في

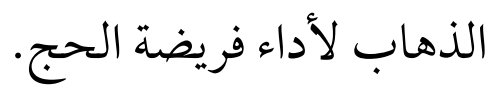
- للموظفة الحق في إجازة وضع لمدة أربعة أشهر، بحد أقصى ثلاث مرات طوال مدة عملها بالخدمة المدنية، على أن تبدأ هذه الإجازة من اليوم التالي للوضع، ويجوز أن تبدأ هذه الإجازة قبل شهر من التاريخ المتوقع للوضع بناءً على طلب مقدم من الموظفة وتقرير من المجلس الطبي المختص. والموظفة تستحق هذه الإجازة حتى لو

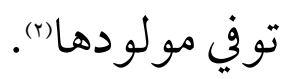
ولعل المشرع قد أراد أن يجعل من هذا القيد سببًا لتحديد النسل، ولكنه لم يعباً بالاعتبارات المحيطة بالطفل وبأمه ، ولا سيما لو مات الطفل الأول أو الثاني . - يستحق الموظف الذي يصاب إصابة عمل ويقرر المجلس الطبي المختص مدة

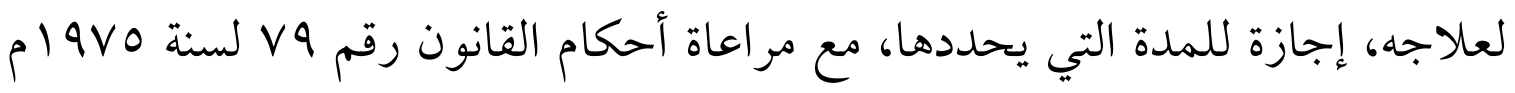


بإصدار قانون التأمين الاجتماعي والقوانين المعدلة له فيما يتعلق بتحديد إصابة العمل والتعويض المستحق . - للموظف المخالط لمريض بمرضٍٍ مُعٍِ ويرى المجلس الطبي منعه لهذا السبب من مزاولة أعمال وظيفته للمدة التي يحددها، فالمدة هنا مفتوحة لا تنتقص من الإجازات المقررة للموظف المخالط للمريض . - يستحق الموظف المقيد بإحدى الكليات أو المعاهد أو المدارس إجازة عن أيام الامتحان الفعلية. ولمنع التحايل من قبل الموظف للتغيب عن العمل بدون وجه حق، يجب عليه أن يقدم ما يثبت دخوله الامتحان، وإلا قُدم للمساءلة التأديبية'). وفي جميع الحالات السابقة تكون الإجازة بأجر كامل، ولا تحسب من الإجازات السنوية أو المرضية المقررة للموظف. ب-إبازات خاصة بدون أجر :-

وقد تحدث عنها المشرع في المادة (ror) من قانون الخدمة المدنية الحالي، وذلك . لمك

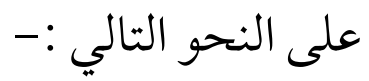
- يمنح الزوج أو الزوجة إذا سافر أحدهما إلى الخارج للعمل أو للدراسة لمدة ستة أشهر على الأقل إجازة بدون أجر مدة بقاء الزوج أو الزوجة في الخارج، وفي جميع الأحوال يتعين على الوحدة أن تستجيب لطلب الزوج أو الزوجة. والحكمة من هذه الإجازة تتمثل في جمع شمل الأسرة وعدم شتاتها، لذا لا يشترط القانون كون أحد الزوجين المرخص له أو لها بالسفر موظفتًا، وسلب القانون كل سلطة تقديرية للإدارة 
بشأن الترخيص بهذه الإجازة، وألزمها بالاستجابة لطلب الزوج أو الزوجة.

- يمنح الموظف إجازة بدون مرتب للأسباب التي يبديها وتقدرها السلطة المختصة حسب مقتضيات العمل، ويدخل في ذلك على سبيل المثال الإجازات الدراسية في الداخل وفي الخارج، أو السفر خارج البلاد للبحث عن فرص عمل أفضل، وهنا أيضًا يكون للإدارة مطلق الحرية في الموافقة على الإجازة أو رفضها ، وفي تحديد مدتها حسب المصلحة العامة . وهذه النوعية من الإجازات ــ الواردة في البندين السابقين ـ تؤثر على الترقية، حيث لا يجوز ترقية الموظف إلا بعد عودته من الإجازة واستكمال المدة البينية اللازمة لشغل الوظيفة الأعلى مباشرة، ولا تدخل مدد الإجازات المنصوص عليها في هذين البندين السابقين ضمن المدد البينية اللازمة للترقية. - تستحق الزوجة الموظفة إجازة بدون أجر لرعاية طفلها لمدة عامين على الأكثر في المرة الو احدة، وبحد أقصى ستة أعوام طو ال مدة عملها بالخدمة المدنية. وفي هذه الحالة تتحمل الوحدة") اشتراكات التأمين المستحقة عليها وعلى

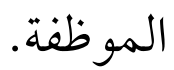

\section{ثالثًا : الرعاية الصحية والاجتماعية والثقافية والرياضية للموظفين :-}

وتعتبر الرعاية في هذه المجالات للموظفين ضمن مكونات الأجور الحافزة التي تدفتهم إلى بذل أقصى جهد يمكن في أداء أعمالهم، لثقتهم في أن الدولة ستوفر لهم كافة

(1) يقصد بالوحدة، الوزارة أو المصلحة أو الجهاز الحكومي أو المحافظة أو الهيئة العامة. مادة (Y/ ع) من قانون الخذمة المدنية الحالي. ويراجع نص المادة (ro من من ذات القانونان. 
الخدمات التأمينية لهم ولأسرهم ضد مخاطر العمل والحياة، كالمرض أو العجز أو الشيخوخة أو الوفاة عن طريق التأمين الصحي للموظفين، هذا بجانب بعض الخدمات الأخرى ، كتوفير المواصلات والسكن والتغذية للموظفين في مناطق نائية، وإنشاء النوادي وتزويدها بوسائل الترفيه والثقافة ، وتنظيم الرحلات ، وأنواع الرياضة، وإقامة المدارس ودور الحضانة لأبناء الموظفين والموظفات، كما تعتبر النظافة والتهوية والإنارة الجيدة ، والهدوء واستخدام الأدوات المكتبية الحديثة من أقوى المؤثرات الرضا الوظيفي لدى الموظف العام، تستطيع من خلالها جهة الإدارة قياس رضاه

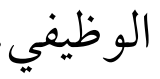
وتمويل هذه الخدمات مشترك بين الموظفين والدولة، حيث يدفع الموظفون اشتراكات تقدر بنسبة مئوية محددة من المرتب، وتتولى القيام بها وزارة أو هيئة عامة على مستوى الدولة، وتحصل اشتراكات تمويل هذه الخدمات وتتولى استثمارها بما يمكنها من مو اصلة تقديم هذه الخدمات") وقد نصت المادة (0ع) من قانون الخدمة المدنية المصري الحالي رقم 1 لسنة الم أم على هذه النوعية من الحو افز بقولها : ": تضع السلطة المختصة بالاشتراك مع اللجنة النقابية للوحدة نظامًا للرعاية الاجتماعية والثقافية والرياضية للموظفين بها، وذلك بمر اعاة أحكام التشريعات ذات الصلة ". ونخلص من كل ما سبق ذكره في هذا الفرع، بأن الأجور الحافزة تنطوي على نوعين من المكونات، مالية وغير مالية، وهي كل ما يعود على الموظف، سواء كانت نقوداً أو

(1) د. حمدي أمين : إدارة شؤون موظفي الدولة، ص عـ ـ 
أموالاً أو خدمات، لقاء تأديته لأعمال وظيفته والتفرغ لذلك، ونظراً لأن الموظف ما لجأ للانخراط في الوظيفة العامة إلا من أجل هذه الأجور لكونه يعتمد عليها في الإنفاق على نفسه ومن يعول، إذاً تعبر من أهم العو امل المؤثرة على رضاه الوظيفي، فإذاذا كانت هذه الأجور بكل مكوناتها تكفي لإحيائه حياة كريمة هو ومن يعول، لا شك في في أن رضاه الوظيفي سيكون في أعلى معدلاته، ولا يخفى على أحد قدر المميزات و التأثير الإيجابي

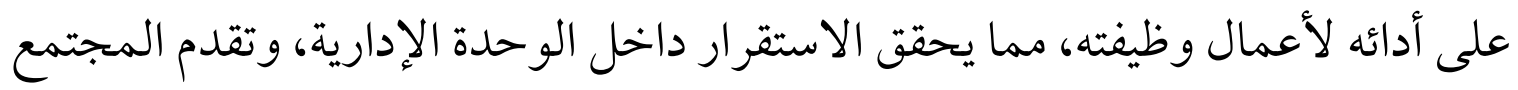
بشكل عام، و العكس صحيح. والسؤال الذي يطرح نفسه على بساط البحث الآن، إذا كانت النظم الوضعية قد عرفت نظام الأجور الحافز بمكوناته السابقة، فهل الإدارة الإسلامية عرفت هذه بهر

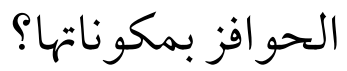
وهذا ما سنجيب عليه في الصفحات التالية من خلال بحث هذا الموضوع في الشريعة

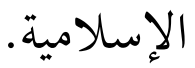

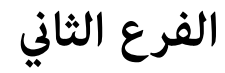 \\ مكونات الأجور الحافزة في الشريعة الإسلامية}

الناظر في تلك الأجور في الشريعة الإسلامية يجدها تشتمل على نوعين من المكونات، الأول: العطايا المالية والنقدية، والنوع الآخر: العطايا غير المالية أو المعنوية، وفي الصفحات التالية نلقي على كلا النوعين. المكونات المالية للأجور الحافزة: المكونات المالية هي : المبالغ النقدية أو العطايا العينية التي تعطى للموظفين لإثارة الرغبة لديهم وتحفيزهم على القيام بو اجبات وظائفهم على خير وجه . 


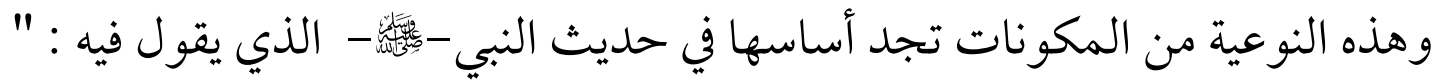
من وّرلِيَ لنا شيئًا فلم يكن له امر أة فليتزوج، ومن لم يكن له مسكن فليتخذ مسكنًا، ومن لم يكن له مركب فليتخذ مركبًا، ومن لم يكن له خادم فليتخذ خادمًا، فمن أعدّ سوى ذلك جاء يوم القيامة غالاً سارقـًا "(1). وتأخذ هذه المكونات في النظام الإسلامي صوراً متعددة منها ، الأجور الحافزة، وسلب القتيل، وغنيمة الحرب، والمكافآت التشجيعية . أولاً : الأجور أو المرتبات :- والأجر هو العوض أو المقابل الذي يتقاضاه الموظف

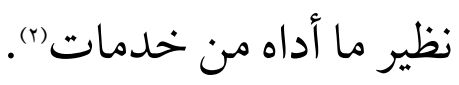
وكانت الإدارة الإسلامية حريصة جداً على اتصاف الأجر بصفة التحفيز، ويتمثل التحفيز في الأجر فيما يراعيه الإسلام عند تقديره للأجر من ضرورة كفاية الأجر للموظف، بحيث يضمن له مستوى لائقًا من الحياة يتناسب مع المستويين الاقتصادي والاجتماعي في البلد الذي يعيش فيه ، لذا يقول أبو يعلى : " وأما تقدير العطاء -

(1) ابن خزيمة : صحيح بن خزيمة ، باب إذن الإمام للموظف بالتزويج واتخاذ الخادم والمسكن من الصدقة ،

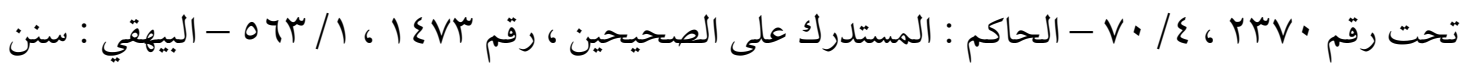

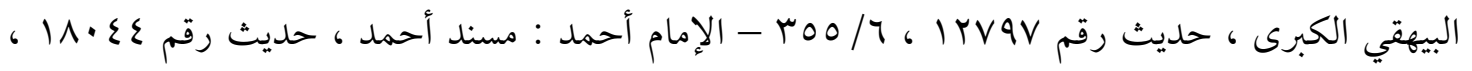
. rYq/६ (Y) عبدالعزيز حمد آل مبارك الإحسائي : تبيين المسالك شرح تدريب السالك إلى اقرب المسالك ، شرح الشيخ

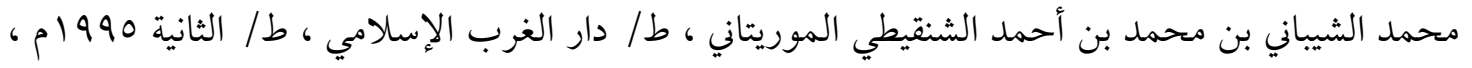

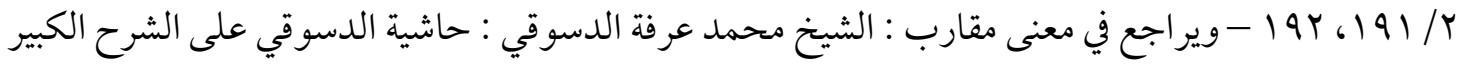

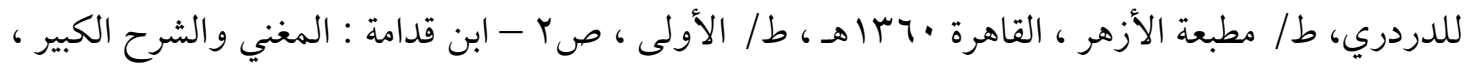

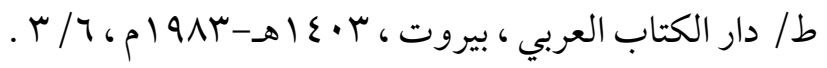


المرتب- فمعتبر بالكفاية ، حتى يستغنى بها عن التماس مادة تقطعه عن حماية

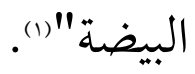

والسبب في ضرورة كفاية الأجر للموظف -كما بينه أبو يعلى- هو عدم انشغاله بطلب الرزق من مصادر أخرى، فيلهيه ذلك عن واجبه الأصلي وهو حماية البيضة -أي الدفاع عن الدين والوطن-، ويعني هذا في مجال الوظيفة العامة أن ضعف الأجر عن ضمان الحد الأدنى للمعيشة يجعل الموظف يرتشي أو يسرق وظيفته أو ما أؤتمن عليه حتى يشبع حاجاته الضرورية. ومن هنا ذهب بعض الفقهاء()، إلى أن يراعى عند تقدير الأجر ثلاثة أوجه :1 - ب عدد من يعولهم الموظف من الذراري . r - ما يكفل الإنفاق على ما يقنيه من الخيل والظهر، أو ضمان الأجر لتكاليف مظاهر الوظيفة وكل ما يتطلبه ذلك لأداء واجباتها على نحو أفضل .

r- مراعاة مستوى الأسعار في المكان الذي يوجد فيه الموظف من رخص أو غلاء، فيقدر كفايته في نفقته وكسوته لعامه كله فيكون هذا المقدر في أجره، ثم يعرض حاله في كل عام فإن زادت حاجاته الضرورية زيد في أجره، وإن نقصت نقص منه .

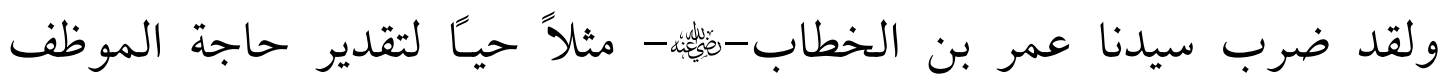
الضرورية من الطعام وما يكفيه ويسد حاجته، مما يعتبر وبحق من أحدث وسائل العصر

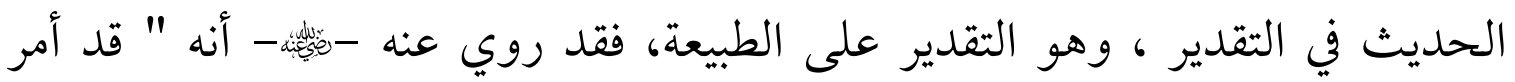


بجريب(1)من القمح فطحن، ثم خبز، ثم ثرد-أي جعل ثريداً- ثم دعا لأكله ثلاثين رجلاً، فأكلوا منه غداهم حتى أصدرهم -أي أشبعهم - ثم فعل في العشاء مثل ذلك، فقال عمر : يكفي الرجل جريبان في الشهر، -باعتبار أن للرجل أكلتان في اليوم- فكان يرزق الرجل والمرأة والمملوك جريبين كل شهر "(().

ويتمثل أيضًا وجه التحفير في الأجر في تمجيد الشريعة الإسلامية للعمل، وفي كفالة

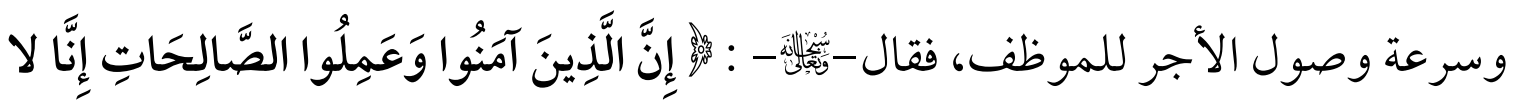

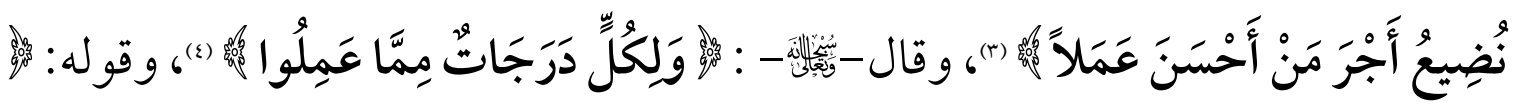

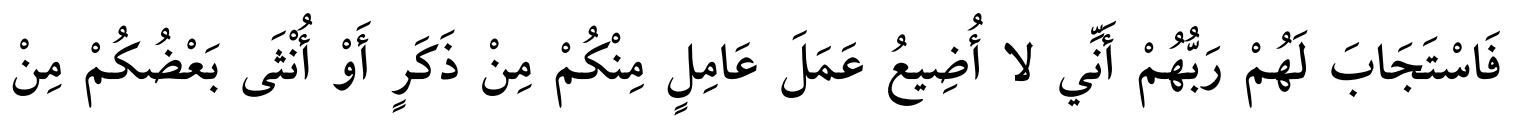
بَعْضِ (0) وجاءت السنة المطهرة تؤكد ذلك، فعن العمل قال النبي-هي طعامًَا قط خير من أن يأكل من عمل يده ، وأن نبي الله داود كان يأكل من عمل يده "(1)، (1) الجريب : مكيال قدر أربعة أقفزة، والقفيز : مكيال كان يكال به قديمكا، ويعادل بالتقدير المصري الحديث نحو ستة عشر كيلو جرامكا، إذا فالجريب يقدر بستين كيلو جرامًا.

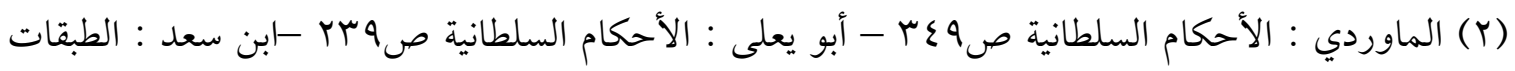

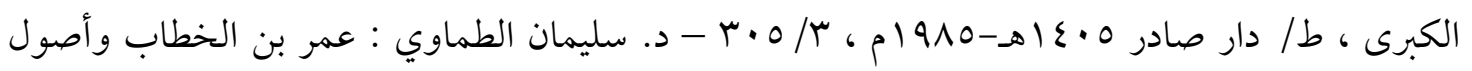

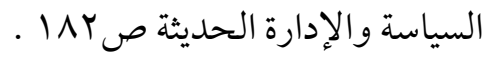

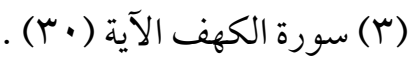

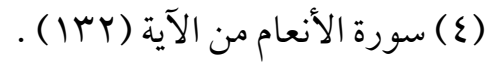

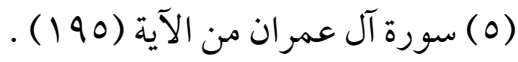
(7) البخاري : صحيح البخاري ، من حديث المقداد ، حديث رقم YV•r ، كتاب البيوع، باب كسب الرجل وعمله بيده، م/T/ 


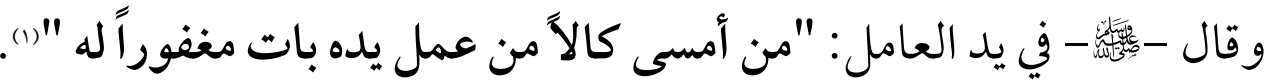

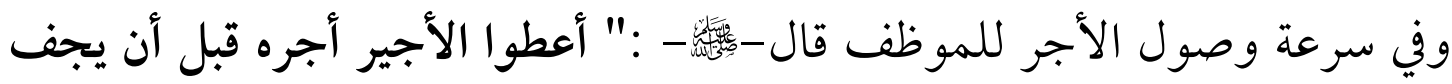

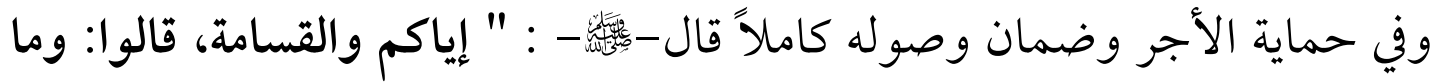

القسامة يا رسول الله ؟ قال : الرجل يكون على الفئام من الناس فيأخذ من حظ هذا وحظ الته

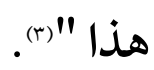

ومن هنا جاءت صفة التحفيز للأجور بالرغم من أنها تعد مقابلاً لما بذله الموظف

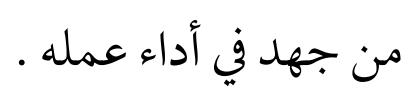

وبذلك كان للشريعة الإسلامية السبق في قيام سياسة الأجور على مراعاة مقدار

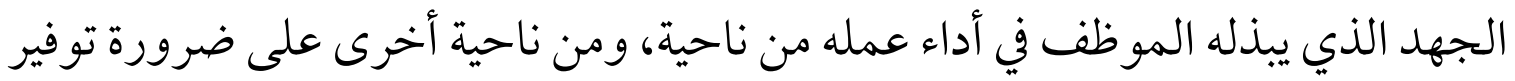

الحد الأدنى على الأقل من حاجته الماسة له ولمن يعول .

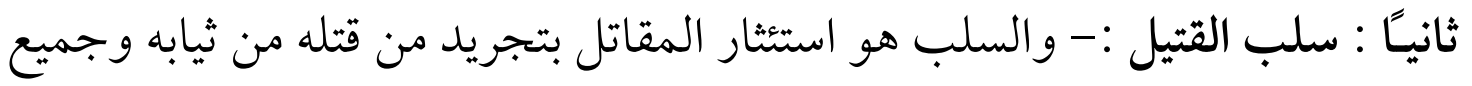

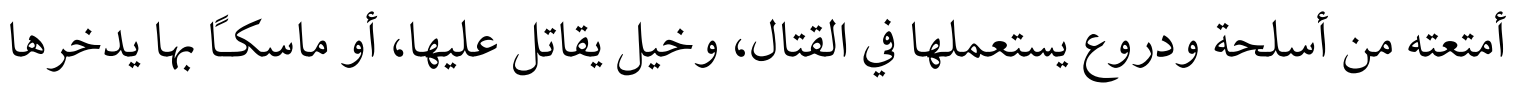

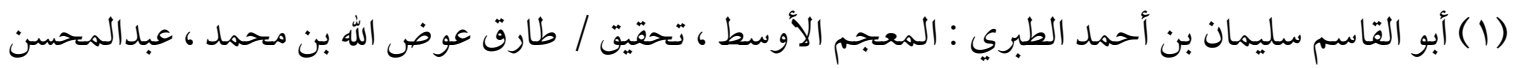

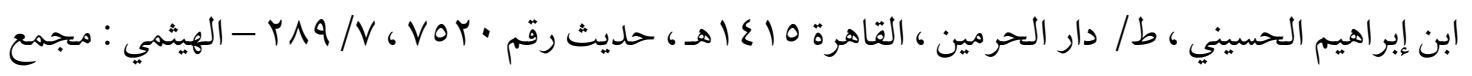
الزوائد ع/ آت .

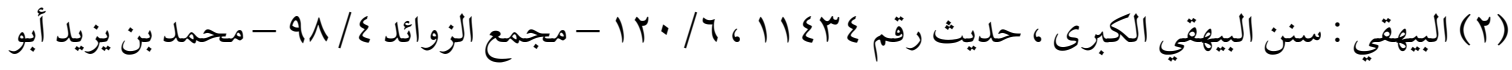

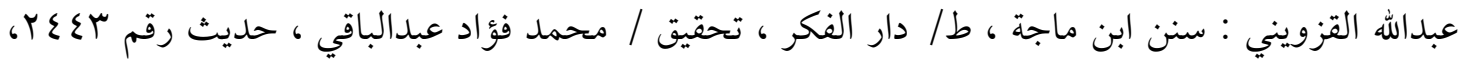
$. \wedge \mathrm{V} / \mathrm{r}$

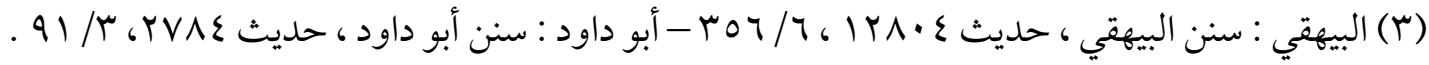


ويعد السلب صورة فعالة من صور التحفيز المالي في النظام الإسلامي، ويتجلى وجه التحفيز في حصول مستحقه -القاتل - عليه كاملاً ويصير ملكَّا خاصـا له (()، مهما بلغت قيمته، لا يز احمه فيه أحد غيره مهما تعددت أسلابه، ومما يدلنا على ذلك قول النبي قتل قتيلاً له عليه بينة فله سلبه "(r). وقد حدثت واقعة في خلافة سيدنا عمر بن الخطاب تؤكد استئثار القاتل بسلب من قتله مهما بلغت قيمته دون أن ينقص منه شيء مؤداها ، أن شابا من المسلمين يقال له "زهرة" عمد إلى "الجالينوس" وهو أحد أمراء الفرس ومن كبار أغنيائهم وقتله وقام بسلبه، وجاء بسلبه إلى قائده سعد بن أبي وقاص، فاستكثر سعد أن ينفرد هذا الجندي

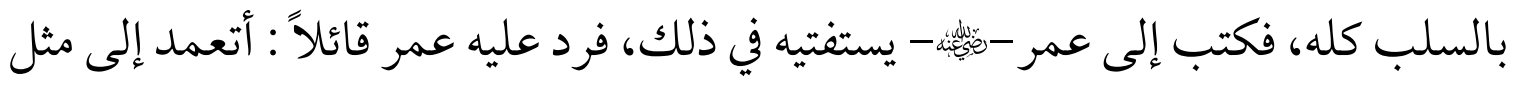

(1) أبو يحيى زكريا الأنصاري الشافعي : كتاب أسنى المطالب شرح روض الطالب، وبهامشه حاشية الشيخ أبو

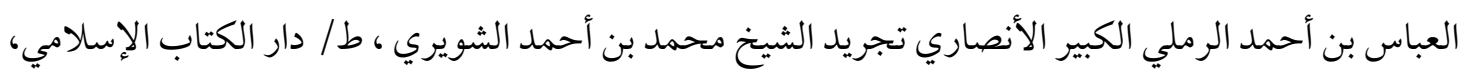

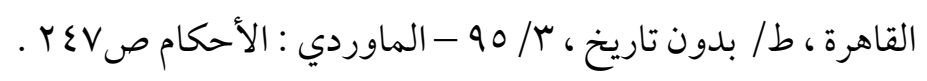

(Y) الشيخ : إبر اهيم الباجوري : حاشية الباجوري على شرح ابن قاسم على متن الشيخ أبي شجاع في مذهب الإمام

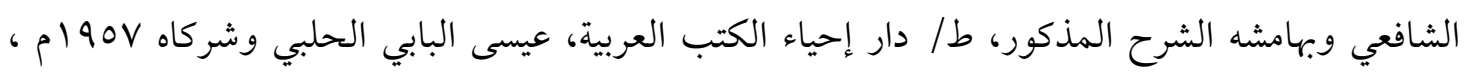

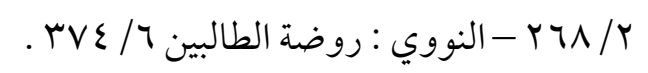

(r) البخاري: صحيح البخاري، كتاب فرض الخمس، باب من لم يخمس الأسلاب ومن قتل قتيلاً فله سلبه من

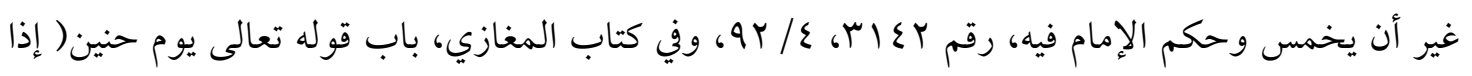

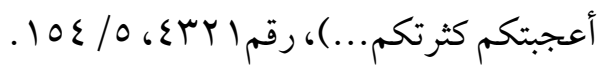


زهرة وقد صلى بمثل ما صلى إليه، وقد بقى عليك من حربك ما بقى، تكسر قرنه وتفسد قلبه، أمض له سلبه، وفضلّه على أصحابه عند العطاء بخمسمائة، فدفع سعد إلى زهرة سلبه، فباعه -كما تذهب بعض الروايات- بسبعين ألف درهم (1) . ومن هنا يعد السلب حافزاً قويـًا يرفع من الروح المعنوية للمقاتلين، ويصل بالرضا الوظيفي عندهم لأعلى معدلاته، مما يدفعهم إلى بذل قصارى جهدهم في قتال العدو، والإجهاز على أكبر عدد ممكن منهم .

لذا رأينا سيدنا عمر يكتب إلى سعد بأن يعوض الجندي عن التأخير في قبض سلبه ، ويميزه على أصحابه عند تقسيم العطاء، ليؤكد له ولغيره من الجند الثبات على المبدأ دائمَا وأبداً.

ثالثًا : الغنيمة :-و الغنيمة لغة : مأخوذة من الغنم وهو الفوز، يقال غَنِمَ المقاتل غنمًَ أي ظفر بمال عدوه، و الغنيمة ما يؤخذ في الحرب قهراً ((). وشرعَّ : ما استولى عليه المسلمون من أموال الكفار بالقتال على سبيل القهر

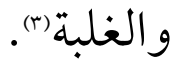

$$
\begin{aligned}
& \text { (1) د. سليمان الطماوي : عمر بن الخطاب وأصول السياسة والإدارة الحديثة ص 110 ـ . }
\end{aligned}
$$

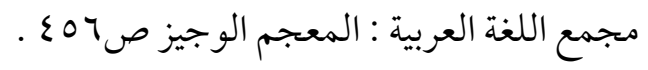

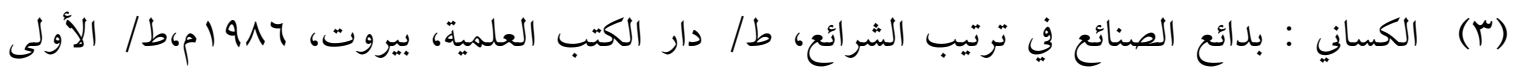
اllV/T Tr/T TY - القاضي عبدالله بن عمر البيضاوي: الغاية القصوى في دراية الفتوى ، دراسة وتحقيق وتعليق علي محي الدين علي القرة داغي ، ط/ دار الإصلاح للطبع والنشر والتوزيع، السعودية، ط/ بدون تاريخ r/ / 901 الشيخ الإحسائي : تبيين المسالك شرح تدريب السالك r / ror ـ - علي بن محمد الجرجاني : كتاب التعريفات

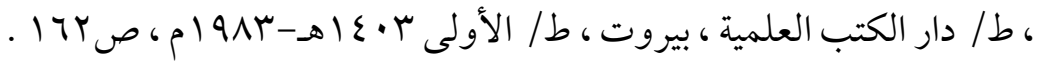




\section{و الغنيمة مشروعة بالكتاب والسنة :}

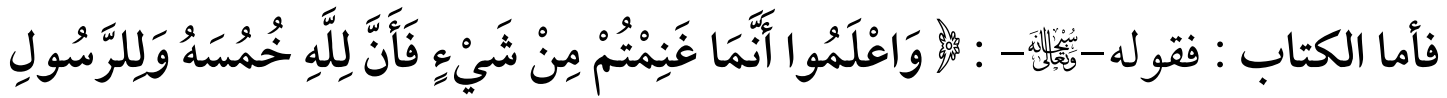

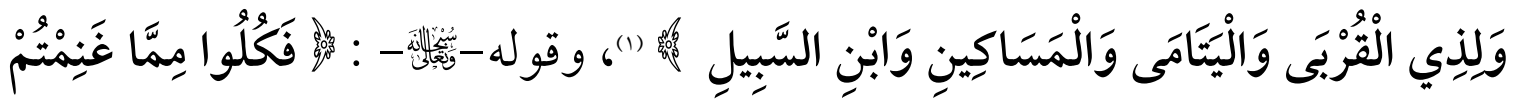

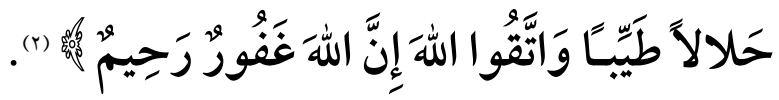

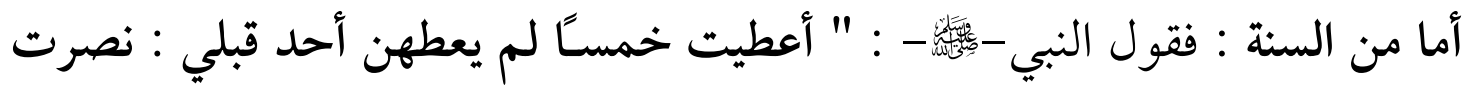
بالعرب مسيرة شهر، وجعلت لي الأرض مسجداً وطهوراً فأيما رجل من أمتي أدركته الصلاة فليصل، وأحلت لي المغانم ولم تحل لأحد قبلي، وأعطيت الشفاعة، وكان النبي يبعث إلى قومه خاصة ، وبعثت للناس عامة "(r). وتعد الغنيمة صورة من صور التحفيز المالي للعسكريين، ويتجلى وجه التحفيز في

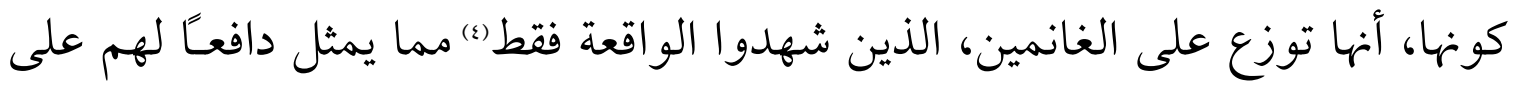
الإسراع والانضمام لصفوف الجيش لقتال الأعداء بحماس، وعدم توانٍ ؛ ليحققوا

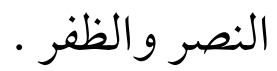

ويتمثل وجه التحفيز أيضًا في الغنائم في أنها تقسم على الغانمين بالعدل، فلا يحابي

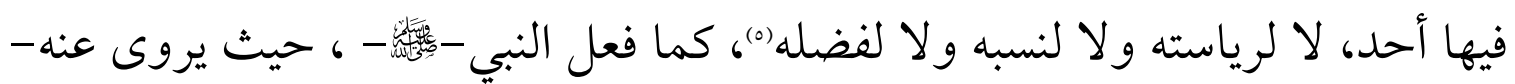

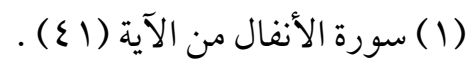
(Y) (Y) سورة الأنفال الآية (79) .

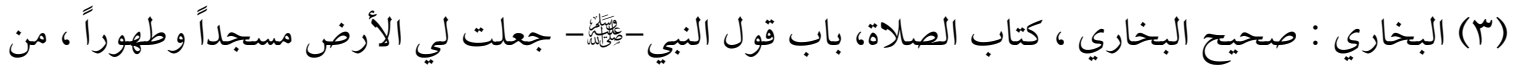

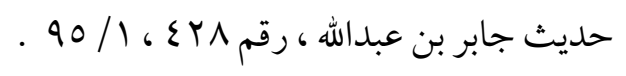

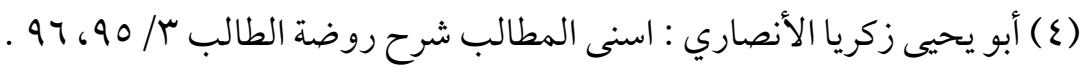

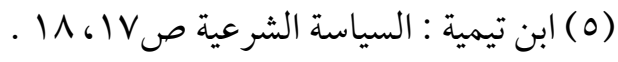




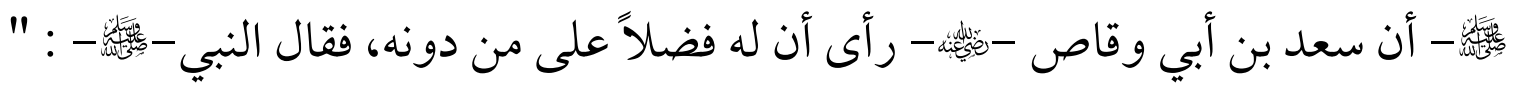
هل تنصرون وترزقون إلا بضعفائكم "(1). وفي مسند أحمد ومصنف عبدالرزاق عن سعد بن أبي وقاص قال : " قلت يا رسول الله الرجل يكون حامية القوم يكون سهمه وسهم غيره سواء ، قال : ثكلتك أمك ابن أم سعـد ، وهل ترزقونوتنصرون إلا بضعفائكم "(r).

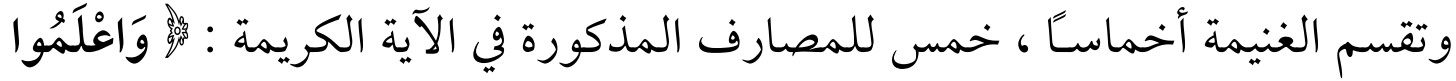

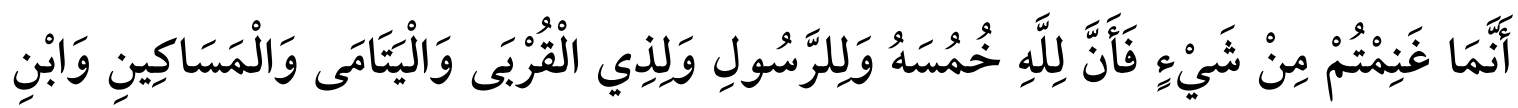
(r) السَّبيل أما عن الأربعة الأخرى : فإنها تقسم على الغانمين، وقد اختلف الفقهاء(8) في كيفية تقسيمها، هل يعطى للفرس سهم أم سهمين، وما أرجحه وأميل إليه أنه يعطى للفارس سهمًا وللفرس سهمين وللراجل سهمَّا، وذلك لما روى أن النبي -

(1) البخاري : صحيح البخاري ، كتاب الجهاد والسير، باب : من استعان بالضعفاء والصالحين في الحرب،

$$
\text { رقمr }
$$

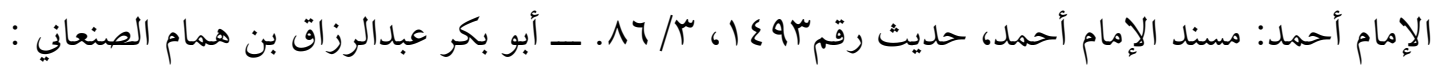

مصنف عبدالززاق : ط/ المكتب الإسلامي ، بيروت ب.عاهـ ، ط/ الثانية ، تحقيق / حبيب الرحمن

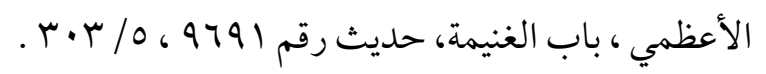

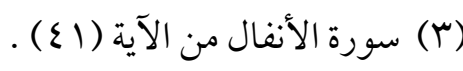

(ع) ) يراجع في هذا : الخلاف كلاً من : الكساني : بدائع الصنائع / عاس - الباجوري : حاشية الباجوري

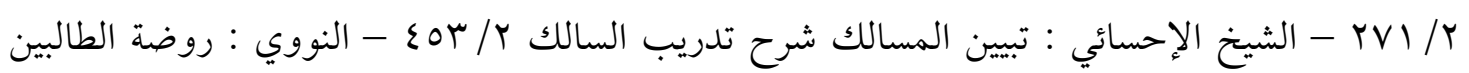

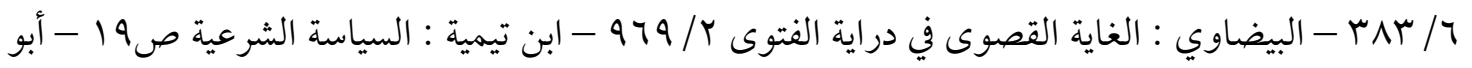

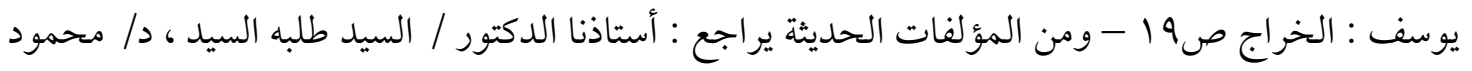

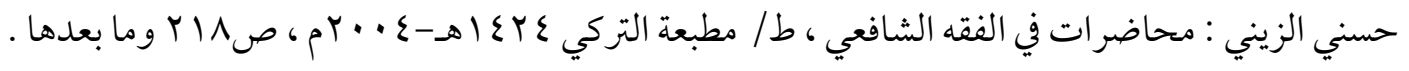


للر جل ولفرسه ثلاثة أسهم ، سهم له وسهمان لفرسهة".

وما دامت الغنيمة تعد حافزاً على القتال فلا يجوز تقسيمها إلا بعد انتهاء الحرب،

ليعلم بانتهائها تحقق الظفر واستقرار الملك، ولئلا ينشغل الجنود بها فيهزمو ("(). .

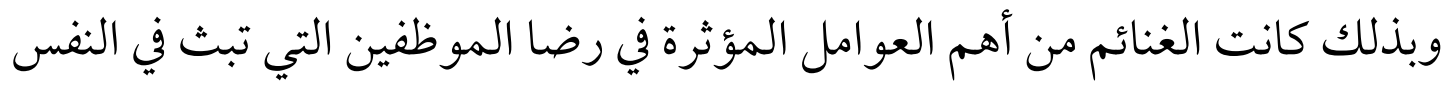

الحماس وروح التضحية، وبذل كل جهد وطاقة لتحقيق النصر والتمكين لدين الله في

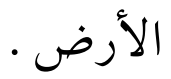

رابعًا : المكافآت التشجيعية :-ما أشرنا إليه سلفَّ من حوافز تمثلت في الأجور

الحافزة، والسلب وغنيمة الحرب قد دلت عليها أدلة قاطعة من الكتاب والسنة، ولم

يقتصر الأمر على ذلك، فبالبحث وُجد أن الإدارة الإسلامية قد اهتدت إلى نوع آخر من

الحوافز المالية يمنح للموظفين المدنيين دلت عليها سوابق تاريخية في عهد كبار

الصحابة، ويمكن أن نطلق على هذه النوعية من الحوافز "المكافآت التشجيعية" وهي عبارة عن مبلغ مالي يمنح للموظف الكفء الذي أجاد في عمله، أو قدم أعمالاً ممتازة لها قيمتها.

ومن التطبيقات على هذه النوعية من الحوافز ما روى أن سيدنا عمر بن الخطاب-

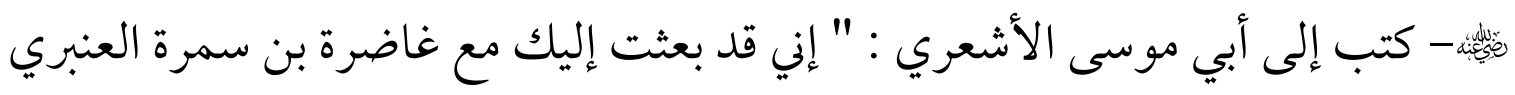

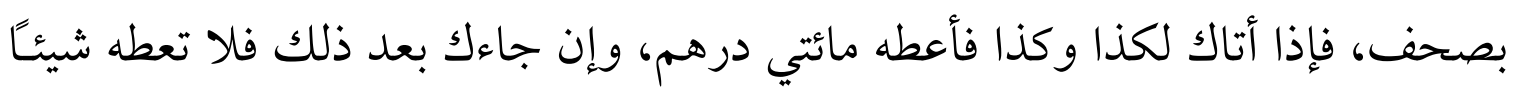
واكتب إلي في أي يوم قدم عليك "(r).

(1) محمد بن عيسى أبو عيسى الترمذي السلمي : سنن الترمذي، طا / دار إحياء التراث العربي ، تحقيق/ أحمد

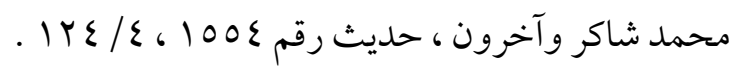

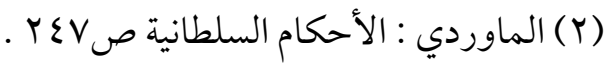

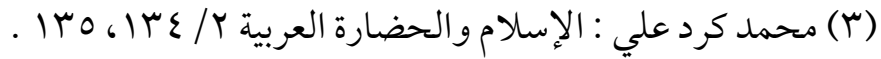


فهنا رأينا سيدنا عمر يحدد مكافأة قدرها مائتي درهم "لغاضرة" وذلك إذا أنجز عمله-وهو إيصال الصحف- في الميعاد المحدد لذلك، فإذا لم ينجز عمله في وقته المحدد يحرم منها .

ومن التطبيقات الواضحة لهذه الحوافز، أن أهل حمص قد شكوا عاملهم سعيد بن

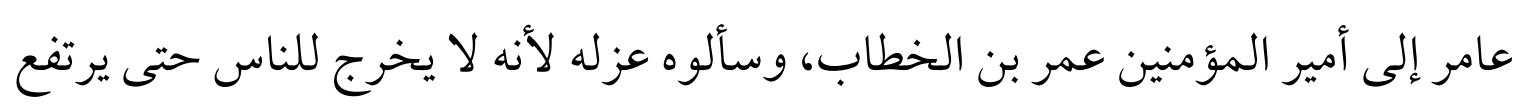

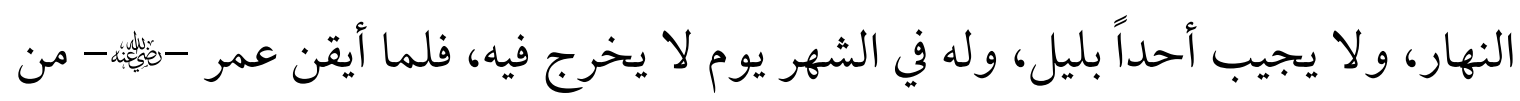
أن عامله يعجن خبزه ويجلس حتى يختمر فيخبز ثم يخرج للناس، وأنه يجعل الليل كله

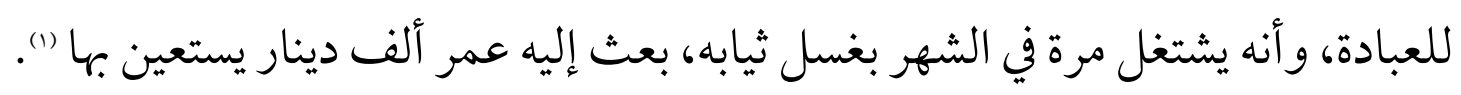
فلما وجد سيدنا عمر عامله سعيد كما أراد أمينًا على وظيفته، حريصًا على طاعة لئه الله في عمله، فقد كافأه بألف ينار ليستعين بها على طاعة الله ، وليزداد أمانة وحرصكا على فيلى وظيفته .

ومن ذلك يتضح أن المكافآت التشجيعية تعطي للموظف المجتهد الذي أخلص وتفانى في أداء واجبات وظيفته حتى أصبح متميزاً في ذلك . وأخيراً وعلى ضوء ما سبق ، إن منح هذه المكافأة يخضع للسلطة التقديرية للإدارة الإسلامية ولم يكن حقَّ مكتسبَّا للموظف سواء تفانى في عمله أم لا ، ولم يكن لها حداً أدنى

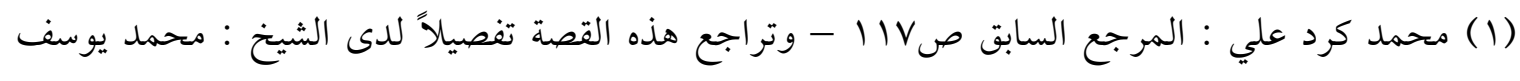

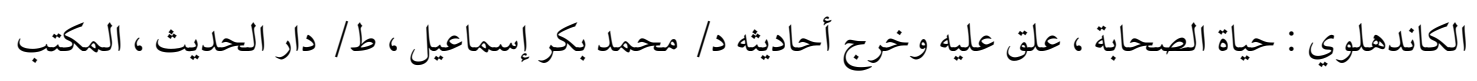

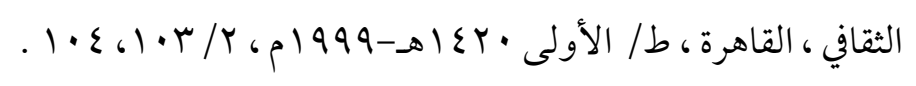


كما لم يكن لها حداً أقصى حتى لو تجاوزت قيمة الأجر الذي يأخذه الموظف، وهي بذلك تختلف عن المكافآت التشجيعية في النظام الإداري الوضعي والتي يشترط فيها عدم تجاوزها قيمة معينة أو نسبة محددة من الأجر الوظيفي الذي يحصل عليه

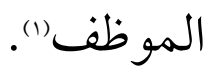

وخلاصة القول أن الشريعة الإسلامية قد لمست ميل الطبيعة الإنسانية للتملك والاستئثار وحب المال، وعلمت مدى تأثيره على معنويات الموظفين ورضتهم عن وظائفهم، وشحذ جهودهم وتسخيرها في خدمة وظائفهم، فأقرت نظامًا محكمًا للإجور الحافزة بمشتملاتها السابقة، للموظفين العسكريين والمدنيين على السواء، فسبقت بذلك كافة النظم الوضعية .

\section{المكونات غير مالية (المعنوية) للإجور الحافزة:}

وبعد أن ضمنت الإدارة الإسلامية حياة كريمة للموظفين عن طريق توفير

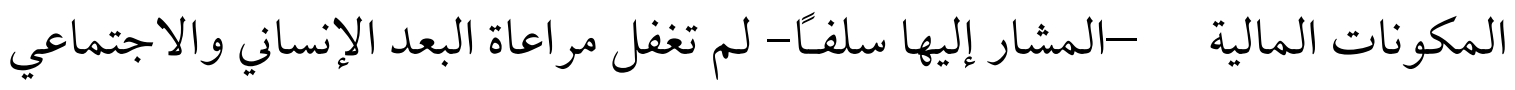
للموظف ولغيره من المسلمين ، فحرصت على توفير الحوافز الإنسانية للموظفين، تلك الحوافز التي تمثل المقابل المعنوي لقيام الموظفين بو اجباتهم الوظيفية، وقد يكون

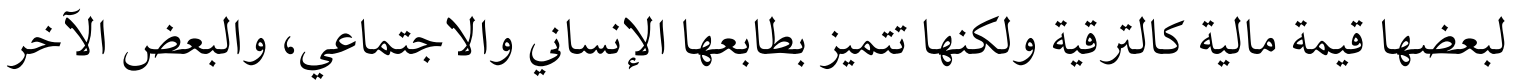
منها يكون غايته توفير الرعاية الصحية، والراحة البدنية لمواصلة العمل بقدرة خلاقة

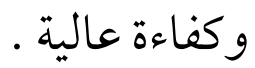

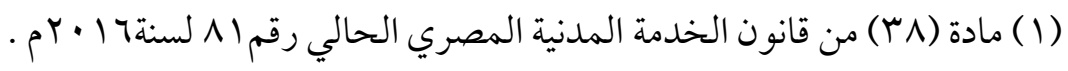


وفي الصفحات التالية نوضح أهم مكونات الأجور الحافزة المعنوية، وذلك على

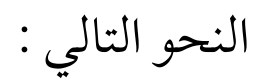

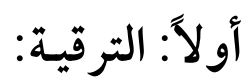

والترقية ببساطة تعني انتقال الموظف من الوظيفة التي يشغلها إلى وظيفة أخرى أعلى منها في الواجبات والمسئوليات، وتجري في النظم المعاصرة على أساس

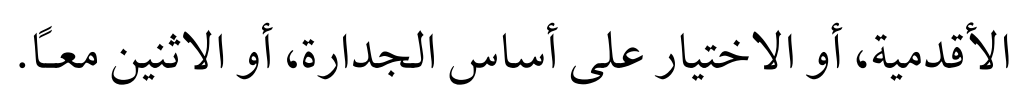

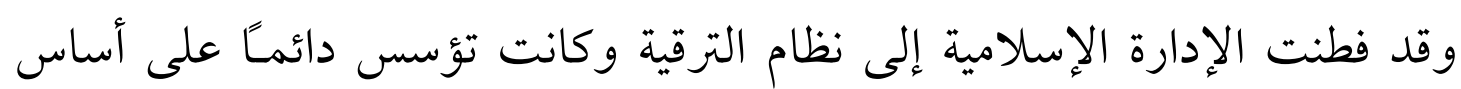
الجدارة أو الصلاحية باعتبارها كانت تأخذ شكل التعيين الجديد في كل مرة، فيكون شأنها شأن التعيينات الجديدة، التي كانت تتم على أساس الصلاحية بركنيها، القوة و والأمانة.

ومن الأمثلة على الترقية في الإدارة الإسلامية، ما فعله سيدنا عمر بن الخطاب من إسناد قيادة جيش المسلمين في الشام إلى أبي عبيدة بن الجراح بعد عزل خالد بن الوليد،

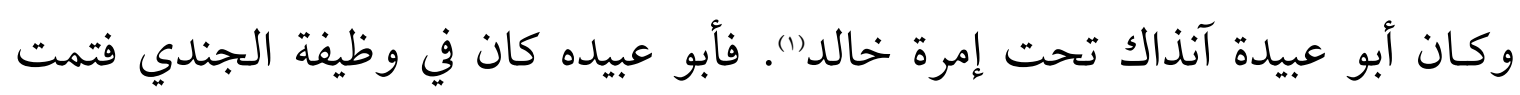
ترقيته إلى وظيفة القائد الرئيس .

وقد أخذت الترقية في الإدارة الإسلامية صورة أخرى، تمثلت في توسيع اختصاصات الموظف، كما فعل سيدنا عمر بن الخطاب مع معاوية بن أبي سفيان عندما أضاف

(1) ابن جرير الطبري : تاريخ الرسل والملوك \&/ جT، IV - خالد محمد خالد : رجال حول الرسول ، ط/ دار

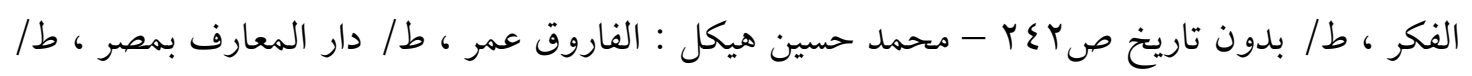

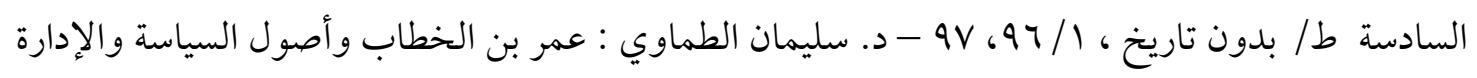
الحديثة، ص.9 r . 
لاختصاصاته ولاية الأردن بعد عزل شرحبيل بن حسنه عنها")، فأصبح معاوية أميراً

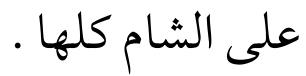
ومن هنا يتبين أن الإدارة الإسلامية قد عرفت نظام الترقي القائم على أساس الجدارة

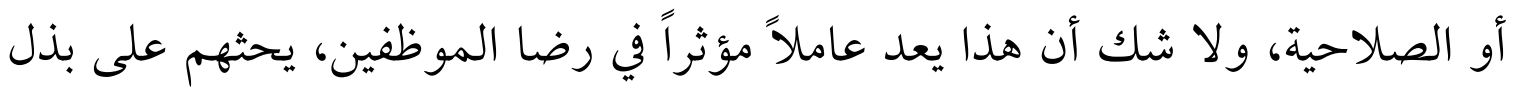
أقصى جهد ممكن في تحقيق أهداف الوظيفة ، حتى يكون عند حسن ظن هيئة الاختيار . ثانيًا : الإجازات :- وقد حرص النظام الإسلامي على ضرورة توفير القدر الكافي من الراحة للموظف كل فترة زمنية يقضيها في أداء عمله، ليستعيد نشاطه لمواصلة أعمال

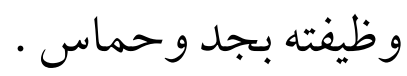
ومشروعية الإجازات تجد أساسها في عدم تكليف الإنسان بما لا يطيق ، قال -

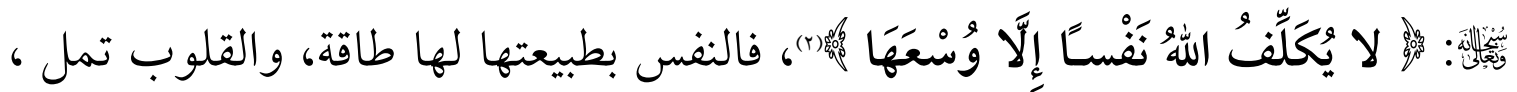
فيلزم لها فترات للر احة والترفيه لتستعيد نشاطها من جديد، لذا يقول النبيلنفسك عليك حق، وإن لبدنك عليك حق ، وإن لأهلك عليك حق فأعط كل ذي حق حقه "(r).

(1) د. سليمان الطماوي: عمر بن الخطاب وأصول السياسة والإدارة الحديثة صr مV - محمد حسين هيكل :

$$
\begin{aligned}
& \text { الفاروق عمر / } \\
& \text { (Y) سورة البقرة من الآية (YNイ) . }
\end{aligned}
$$

(r) أبو الحسن نور الدين علي بن أبي بكر بن سليمان الهيثمي: مجمع الزوائد ومنبع الفو ائد، تحقيق: حسام الدين

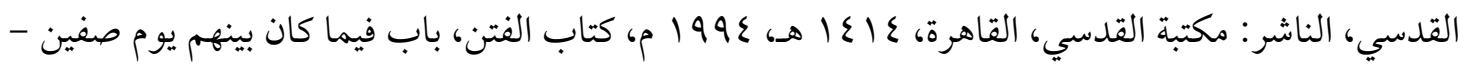

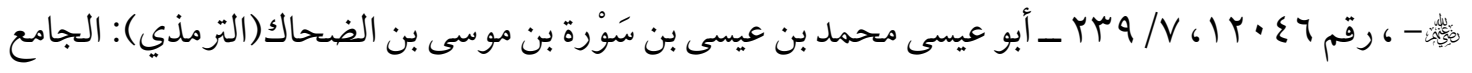
الكبير - سنن الترمذي-، تحقيق: بشار عواد معروف، دار الغرب الإسلامي - بيروت، 991 ام، أبواب الزهد،

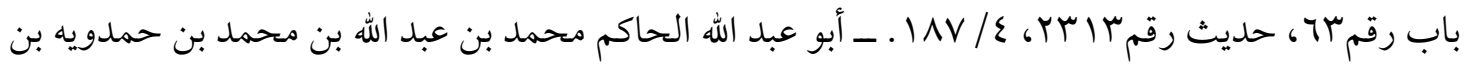


واستناداً إلى هذه الأصول أقرت الإدارة الإسلامية نظام الإجازات، فسمحت للموظف بيوم إجازة كل أسبوع ، فضلاً عن حقه في طلب إجازة خاصة لأسباب خاصة، بجانب الإجازة الاعتيادية .

فبالنسبة للإجازة الأسبوعية : فقد حدد يوم الجمعة من كل أسبوع لراحة الموظفين ،

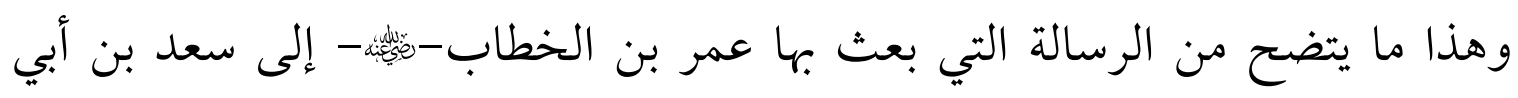
وقاص، يقول فيها: " ترفق بالمسلمين في مسيرهم، ولا تجشمهم مسيراً يتعبهم ، ولا تقصر بهم عن منزل رفق حتى يبلغوا عددهم ، والسفر لم ينقص من قوتهم ... و أقم بمن معك في كل جمعة -أي أسبوع- يوم وليلة حتى تكون لهم راحة يجمعون فيها أنفسهم، ويرمون أسلحتهم و أمتعتهم (1) .

أما عن الإجازة الخاصة ، فهي التي كانت تمنح للموظف لأسباب خاصة تتعلق به، كإجازة الحج التي تعطى للموظف لأداء هذه الفريضة بعد استئذان الحاكم أو الرئيس الإداري، ومما يدل على ذلك أن عتبة بن مروان والي البصرة في عهد عمر بن الخطاب-

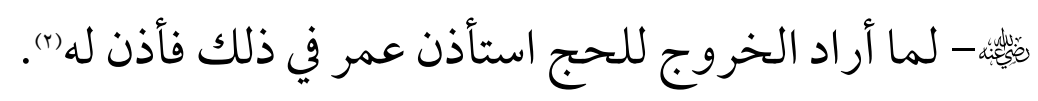
وبالنسبة للإجازة الاعتيادية : وهي التي تمنح للموظف بصفة دورية كل فترة زمنية

نُعيم بن الحكم النيسابوري المعروف بابن البيع: المستدرك على الصحيحين، تحقيق: مصطفى عبد القادر

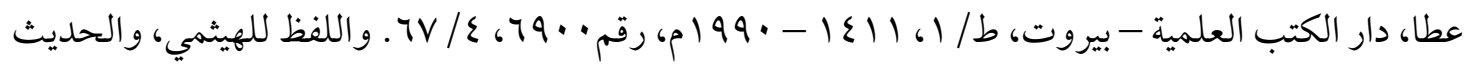
صححه الألباني. (1) د. سليمان الطماوي: عمر بن الخطاب وأصول السياسة صا9ף - خالد محمد خالد : خلفاء الرسول

$$
\begin{aligned}
& \text { ص.rVIGV }
\end{aligned}
$$

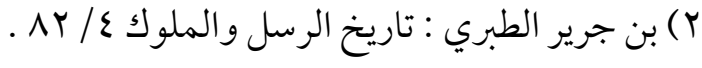


محددة غالبًّ ما تكون سنة، قد أقرتها الإدارة الإسلامية. .

ومما يروى في ذلك أن القاضي محمد بن يبقى كان لا يحكم في شهر رمضان، ويتفرغ للعبادة، ولم يزل مواظبـا على ذلك حتى مات (1).

ومن ذلك يتضح أن الإسلام قد أقر نظام الإجازات باعتباره من أهم الحوافز المعنوية التي تعمل على توفير الراحة اللازمة للموظفين لمواصلة أعمالهم بحيوية

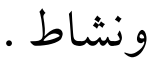

ثالثًا : الرعاية الصحية والاجتماعية :- عرفت الإدارة الإسلامية مقدار وأهمية الرعاية الصحية والاجتماعية على رضاء الموظف عن أعمال وظيفته، فسعت جاهداً لتوفير أكبر قدر من هذه الرعاية للموظف، حتى تصل برضاه الوظيفي إلى أعلى

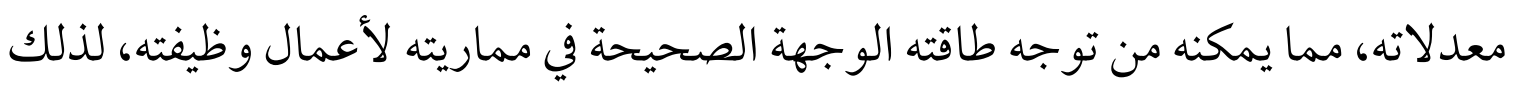

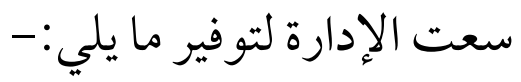
1-توفير المسكن ووسائل المواصلات لكل موظف :-- حرصت الشريعة الإسلامية على توفير المسكن الصحي والملائم لكل موظف، ووسيلة المواصلات المناسبة

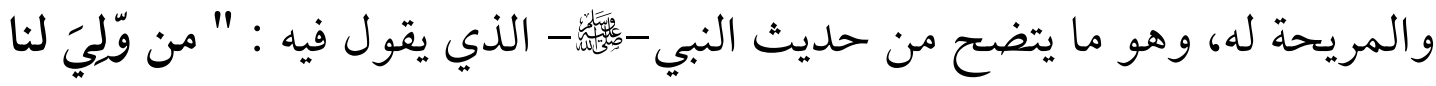
شيئًا فلم يكن له امر أة فليتزوج، ومن لم يكن له مسكن فليتخذ مسكنًا، ومن لم يكن له مركب فليتخذ مركبًا، ومن لم يكن له خادم فليتخذ خادمًا، فمن أعدّ سوى ذلك

(1) د. ظافر القاسمي : نظام الحكم في الشريعة والتاريخ الإسلامي ، السلطة القضائية ، ط/ دار النفائس، ط/

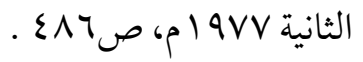




\section{جاء يوم القيامة غالاً سارقتًا " (1)}

ويتضح من هذا الحديث أن النبي - قد للموظف ، حتى يستقر في عمله ويطمئن على مستقبل أسرته، ويعيش راضيًا سعيداً ، في

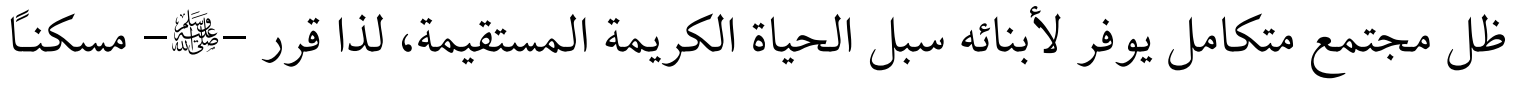
لكل موظف، كما شعر بضرورة وصول الموظف إلى مقر عمله في موعده دون أن تنتهك قو اه بفعل المو اصلات السيئة -هذا إذا كانت موجودة أصلاً الآن- فأمر توفير وسيلة مو اصلات سهلة ومريحة لنقل الموظف إلى مكان عمله . Y-الرعاية الصحية :- قد حرمت الشريعة الإسلامية كل من يضر بصحة الإنسان ، وحثت الموظف على المحافظة على صحته و البعد عن كل ما يسوؤها أو يضر بها

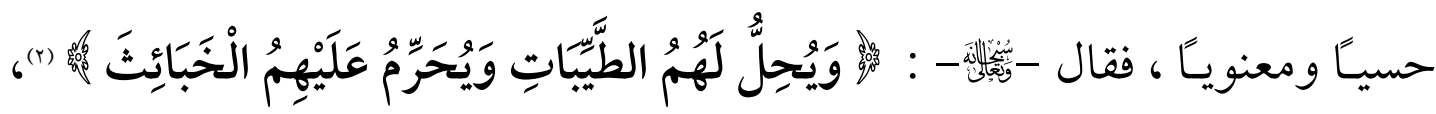
والخبائث كل ما يضر بجسم الإنسان ، وذلك حماية لفئة الموظفين وغيرهم، وحفاظًً على طاقاتهم وقدراتهم بهدف استغلالها في النهوض بمستوى الأمة الفكري والاقتصادي بما يعود بالخير والسعادة على المجتمع الإسلامي بأسره . وقد لمس طاهر بن الحسين ذلك، فكتب لابنه عبدالله يقول : " وانصب لمرضى المسلمين دوراً تأويهم، وقواما يرفقون بهم ، وأطباء يعالجون أسقامهم "(r).

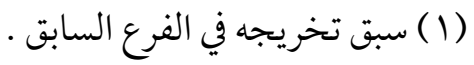

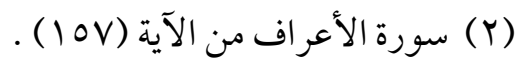

(r) عبدالرحمن بن خلدون : مقدمة ابن خلدون الجزء الأول من كتاب العبر وديو ان المبتدأ والخبر في أيام العرب و العجم والبربر ومن عاصرهم من ذوي السلطان الأكبر ، ط/ الرابعة ، ط/ دار الكتب العلمية ، بيروت 
r-الإثادة بالموظفين الأكفاء :- وهذه صورة من صور التحفيز الإنساني التي عرفتها الإدارة الإسلامية، تتمثل في إعطاء الموظف الكفء ما يستحقه من المدح والثناء بما يشعره بالرضا وتحقيق الذات ، ويشبع غريزته الإنسانية والتي دائمَّا ما تميل إلى لى

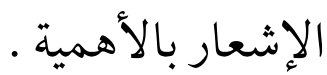
من ذلك ما أثنى به النبي - ملف

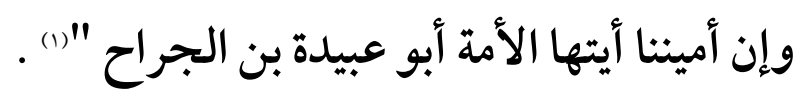

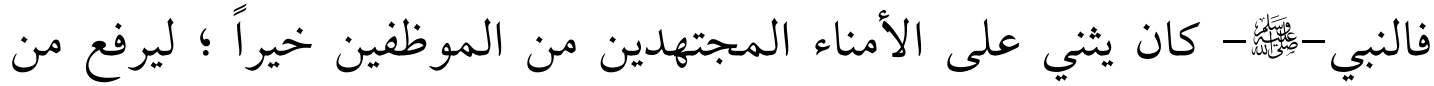

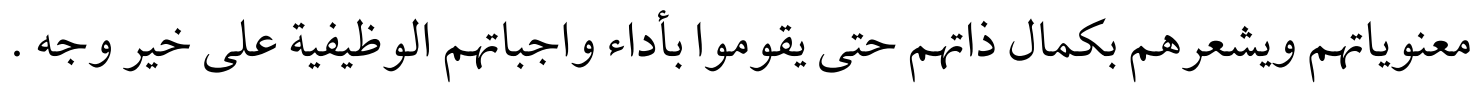
وهذه الصورة من الحوافز تقابل ما يعرف في عصرنا الحالي بمنح شهادات التقدير والأنوطة والنياشين للموظفين المتميزين .

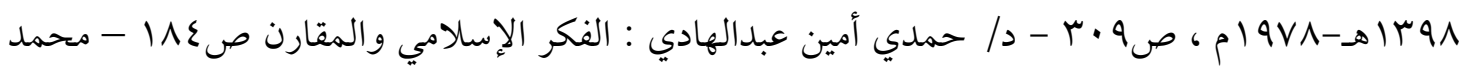
كرد علي :الإسلام والحضارة العربية Y / Y - د / محمد ماهر حمادة : الوثائق السياسية والإدارية العائدة

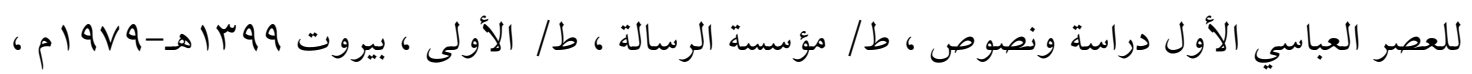
.$r \cdot \cdot \cdot 0$

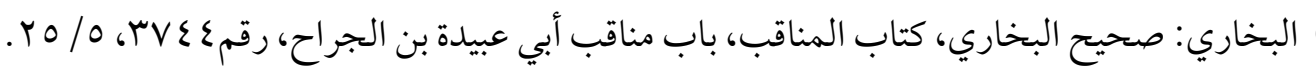

الإمام ابن الجوزي : صحيح البخاري مع كشف المشكل ، تحقيق د/ مصطفى الذهبي، طا / دار الحديث، القاهرة

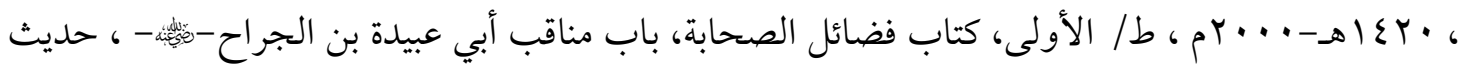

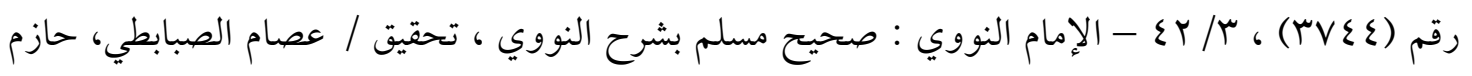

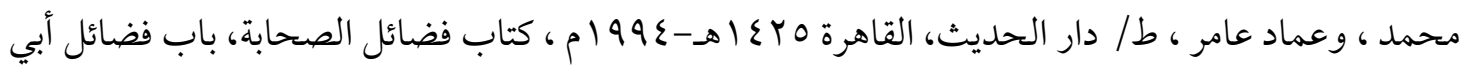

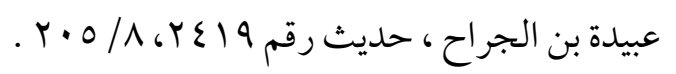


ونخلص مما سبق إلى أن الشريعة الإسلامية كما أقرت وعرفت مكونات الأجور الحافزة المالية، عرفت مكوناتها المعنوية التي تعمل على الارتقاء بمستوى الموظفين الروحي والإنساني، وتوفر لهم الطمأنينة والاستقرار وصفاء قلوبهم من كل كدر وهم؛ ليتفرغو التحقيق مستوى أفضل من الكفاية الوظيفية . ومن هنا يمكننا القول أن الشريعة الإسلامية كان لها السبق في إقرار نظام للأجور الحافزة في الوظيفية العامة بصورة بلغت من الدقة والتنظيم ما عجزت الكثير من النظم الوضعية من الوصول إليه، وذلك لإيمانها بأن هذه الحوافز لها تأثير إيجابي على رضاه الوظيفي، ذلكم الرضا الذي يجعله يقبل على أداء واجبات وظيفته بقلبه قبل جوارحه.

\section{المطلب الثالث أسس وطرق تقدير الأجـور الحافزة}

أشرنا فيما سبق إلى أن الأجور الحافزة هي كل ما يعود على الموظف من مزايا مالية، نقدية أو عينة، ومزايا غير مالية لقاء قيامه بأعباء وظيفته، وأن صفة التحفيز لهذه الأجور تتمثل في كونها تو اجه كافة أعبائه وتسد كل احتياجاته، خاصة الضرورية، لتوفير

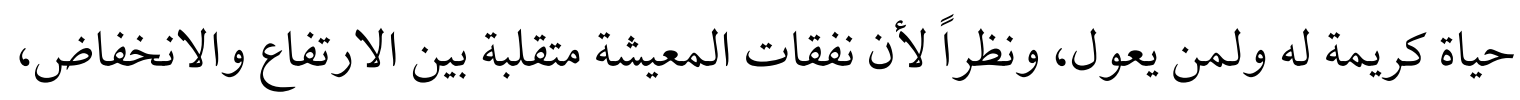
فقد لجأت بعض الدول إلى إعادة النظر في المرتبات بصفة دورية لعلاج جمودها

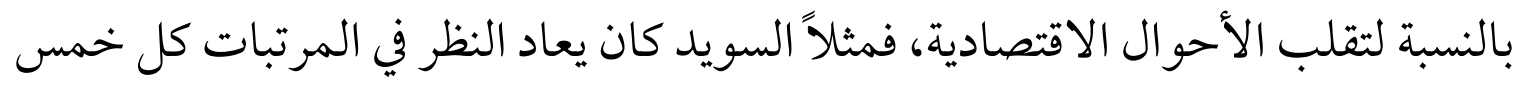
أو ست سنوات، ثم أصبح يعاد النظر فيها سنويتًا، كما هو الحال في فرنسال).

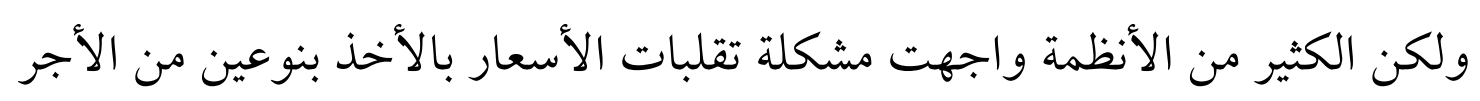

(1) يراجع تقرير لجنة دراسة الوظائف العامة في بورما ص9ه ، أشار إليه د/ حمدي أمين : إدارة شئون موظفي

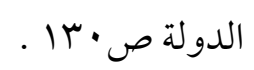


أو المرتب، هما الأجر الثابت، والأجر المتزايد، ويطلق عليه أحيانًا الأجر المتغير، تسعى من وراء النوع الأول إلى توفير الحد الأدنى من احتياجات الموظف في وقت إصدار القانون، وتسعى من خلال النوع الثاني إلى مواجه ارتفاع الأسعار، والمواءمة بين القدر الممنوح من هذا الأجر وأعباء الوظيفة والمستوى العلمي لشاغليها، وبين موارد الخزانة العامة ومقدار الدخل القومي. ولكي يمكن وضع هيكلة للأجور تلمس الرضا الوظيفي لدى الموظف العام وترفع من معدلاته، لا بد من المرور بجملة من العوامل، وعدد من المراحل، تبدأ بتحليل الوظائف وتقييمها، وتنتهي بتصميم نظام للحوافز والبدلات يحقق العدالة في منح

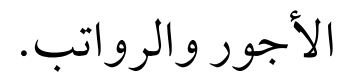

فالأجر الأساسي أو الثابت يجب أن يتم تقديره على أساس تحليل الوظائف

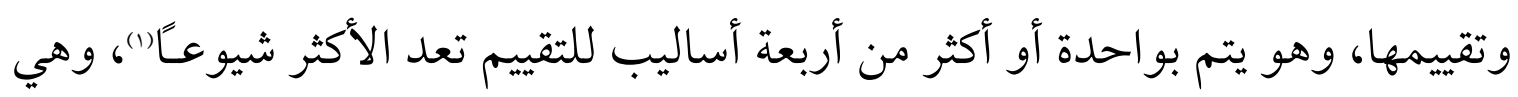
طريقة الترتيب البسيط، وطريقة التدرج، وطريقة التقييم بالنقاط، وطريقة العوامل المقارنة، وهذا يقوم به متخصصون في الموارد البشرية. فطريقة الترتيب البسيط، تقوم على أساس ترتيب الوظائف من حيث الأهمية، فيتم

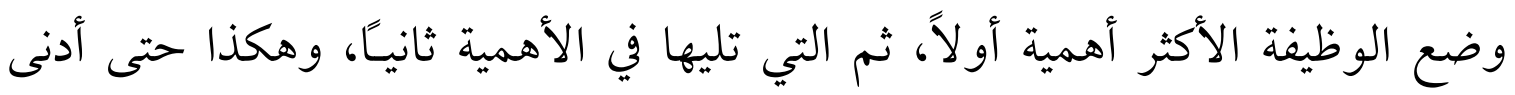
الوظائف في الجهاز الإداري.

(1) يراجع للمزيد، عبد الحميد عبد الفتاح المغربي، وعبد العزيز بن سلطان العنقري: إدارة الموارد البشرية

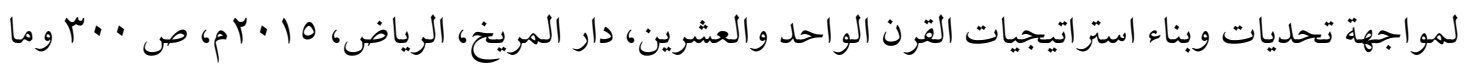
بعدها . ـ د. عبدالحميد عبدالفتاح المغربي: دليل الإدارة الذكية لتنمية الموارد البشرية في المنظمات المعاصرة، القاهرة، V. . Tم، ص 70. 
أما طريقة التدرج، فتحدد مقياسَّا لتدرج الوظائف، ويتم تقسيم الوظائف غالبًا إلى مجموعات متماثلة، أو قريبة من التماثل من حيث طبيعة المهام و الواجبات، كمجموعة الوظائف القيادية، ومجموعة الوظائف التخصصية، ومجموعة الوظائف الحرفية و الفنية، وهذه الطريقة هي الأكثر شيوعَّ في ترتيب الوظائف العامة. وعلى العكس لما سبق، تأتي طريقة التقييم بالنقاط على أسس كمية، حيث تعتمد في تقدير العوامل المكونة للوظيفة على أسس رقمية، وفقًا لستة بنود أساسية هي، المعرفة والتعليم، المهارات المطلوبة، المسؤوليات والمجهود العقلي، المجهود البدني، ظروف العمل، ، ويضاف لها بنود أخرى، كالخبرات السابقة، التدريب، وهذه الطريقة ترتبط بها طريقة مقارنة العوامل التي بدلاً من اعتمادها على مقارنة الوظيفة بغيرها كوحدة واحدة، فإنها تقوم بمقارنة كل وظيفة بغيرها تحت عامل من عوامل التقييم على

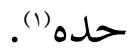
وعلى أي حال، يجب عند تقدير أو تحديد الأجور الحافزة مراعاة جملة من الأسس أو العناصر الأساسية التي يعتمد عليها هذا التقدير كي تتمتع بصفة التحفيز وتلبي حاجات الموظفين، ومن أهم هذه الأسس أو العناصر ما يلي:-(r)

(1) د. محمد أحمد عادل: نحو نظام للأجر العادل في مصر، بحث منشور في مجلة مصر المعاصرة، تصدرها الجمعية المصرية للاقتصاد السياسي والاحصاء والتشريع، العدد الب0، السنة المائة وسبعة، يناير 17 •بم، ص . Y07 600

(Y) لمزيد من التفصيل يراجع، د. محمد السيد محمد الدماصي: سياسة الأجور والمرتبات، الناشر اتحاد

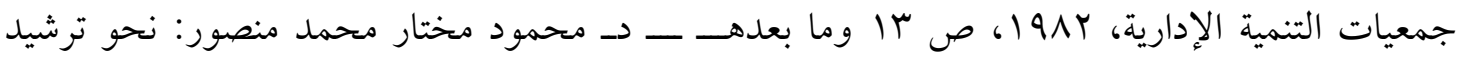
سياسات الأجور والمرتبات في قطاع الدولة في مصر، المؤتمر العلمي السنوي الثامن للاقتصاديين المصريين: 
1- مستوى المسؤولية طبقًا لما هو محدد في بطاقة وصف الوظيفة، فأية عوامل أو ظروف تؤثر في واجبات العمل أو صعوبة أدائه يتعين أن توضع في الاعتبار عند تقويم هذه الو اجبات وتحديد الدرجة المالية لها. r- ربط سياسة الأجور بالناتج القومي المحلي ومعدلات التنمية، حيث إن الأجور

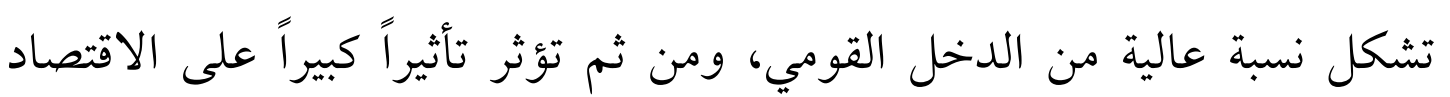
القومي، وبذلك يكون رفعها أو خفضها يتوقف إلى حد كبير على ما يكون عليه الاقتصاد القومي من انتعاش أو انهيار. r- ربط سياسات الأجور بتطور ارتفاع نفقات المعيشة في حدود الدخل القومي، والهدف من ذلك هو، أن يكفل رفع مرتب الموظف تبعَّ لزيادة تكاليف المعيشة، حياة كريمة يستطيع أن يقوم الموظف بعمله وهو آمن. وقد استقر في الوجدان، أن مراجعة الأجور و المرتبات وفقـَ لارتفاع نفقات المعيشة قاعدة عالمية مسلم بها في معظم دول العالم، على اختلاف فيما بينها في فترة المراجعة، حيث تتم المر اجعة مرة كل عام، أو عدة مرات في السنة). ففي فرنسا صدر في 11 يوليو 90 1 (م، قانون يقضي بربط الأجور بالأسعار، وأعدت لذلك أول قائمة قياسية للسلع تضم با ب سلعة، وتم تحديد المستوى الأدنى للأجور

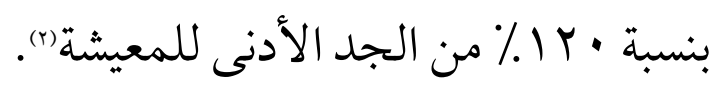

دور الدولة في النظام الاقتصادي المختلط، الذي أقامته الجمعية المصرية للاقتصاد السياسي والإحصاء

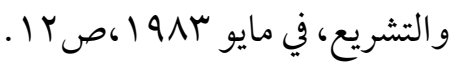

$$
\begin{aligned}
& \text { (1) د. محمود مختار منصور: نحو ترشيد سياسات الأجور و المرتبات في قطاع الدولة في مصر، صسا ه } \\
& \text { (Y) د. محمد السيد الدماصي: سياسات الأجور والمرتبات، صعاك } 10 .
\end{aligned}
$$


وفي الولايات المتحدة الأمريكية توجد لجنة يمثل فيها ديوان الخدمة المدنية ووزارة العمل وإدارة الميزانية، نيط بها تقديم تقرير سنوي إلى الكونجرس ورئيس الجمهورية عن أية تغيرات في الأسعار، أو غيرها تدعو إلى إعادة النظر في معدلات الأجور

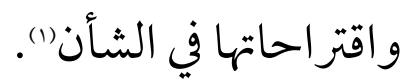

وعلى ذلك فالربط بين تقلبات الأسعار وزيادة أعباء الموظف العام من أهم العوامل أو الأسس التي توضع في الاعتبار تقدير الأجور ورسم سياستها كي يعيش حياة كريمة ويتفرغ لأداء واجبات وظيفته كما ينبغي.

ع - ضرورة أن تعمل الدولة على تحديد سياسات واضحة تتعلق بالحد الأدنى والأعلى للأجور مراعى فيه ظروف الزمان و المكان يتم تنفيذه بصر امة. ه - مراعاة قو اعد المساواة والعدالة في تقدير الأجور و المرتبات لكافة الفئات الوظيفية، حيث إن الأجر يجب أن يكون مساوٍ للإسهامات التي يؤديها الموظف، وأن يكون راتبه مساوٍ لما يتلقاه الموظفين الآخرين مقابل إسهاماتهم، فالحجم النسبي لما يحصل عليه الموظف في مقابل ما يحصل عليه غيره من الموظفين على إسهاماتهم، يمكن أن يكون له تأثير كبير على الرضا الوظيفي لدى الموظف العام. فالموظف ينظر إلى الجهد الذي يبذله في أداء واجبات وظيفته والانتاج الذي يحققه، ثم ينظر إلى العائد نظير هذا الجهد، فيعقد مقارنة بينهما، ثم يقارن بين ذلك وبين ما يحصل عليه موظف آخر، وما يؤديه هذا الموظف من واجبات وما يحققه من انتاج، فإذا اسفرت المقارنة عن مساوة بينها، فإنه يتفهم الموقف وعندها لا يوجد توتر، أما إذا كان العكس، فلا شك أنه سيوجد توتر وعدم رضا، ومن ثم سيؤثر ذلك سلبًا على (1) (1) د. محمد السيد الدماصي: المرجع السابق، نفس الموضع. 
أداء الموظف، فمراعات قواعد العدالة والمساواة في تقدير الأجور أمر ضروري لتأثيره على الرضا الوظيفي لدى الموظف العام. 7- وأخيراً، من البديهي أن يكون للاقتصاديين ورجال القانون والخبراء في مجال التخطيط والموارد البشرية الدور الأساسي في تحدير قيمة الأجور ومعدلات الزيادة فيها بدلاً من تركلها للتقديرات العشوائية التي تتم بواسطة موظفي الخزانة العامة،

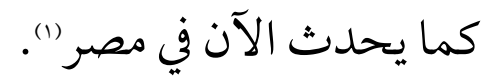

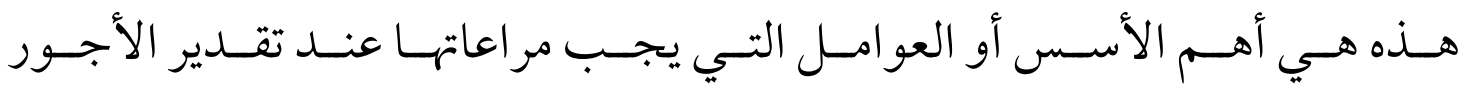
الحـافزة، حتي يكـون لهـا تـأثير إيجـابي على رضـا الموظف العـام، ومـن ثـم تحسـين

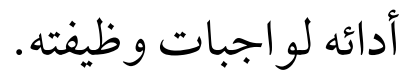

أما عن طرق تقدير الأجور الحافزة، فقد سبق القول بأنه عند تقدير الأجور، يكون هناك أجر أو مرتب ثابت أو أساسي، وأجر متزايد يضم كافة العلاوات والمكافآت التي يحصل عليها الموظف، وقد جرت العادة أن يتم تقدير الأجر الأساسي بعدة طرقن من أهمها ما يلي:الطريقـة الأول : المربــوط المتــداخل :-وتعنـي تـداخل مربــوط الفئـات الوظيفيـة مع الفئات الأعلى منها، و المثال التالي يوضح ذلك :

\begin{tabular}{|c|c|c|}
\hline \multicolumn{2}{|c|}{ المــــــــــــــــب } & \multirow[t]{2}{*}{ الفئة الوظيفية } \\
\hline نهاية المربوط & بداية المربوط & \\
\hline 0. & r. & الرابعة \\
\hline$\varepsilon$. & $r \cdot$ & الخامسة \\
\hline r. & 1 . & السادسة \\
\hline
\end{tabular}

(1) د. محمود مختار منصور: نحو ترشيد سياسات الأجور و المرتبات في قطاع الدولة في مصر، صـ1ا. 


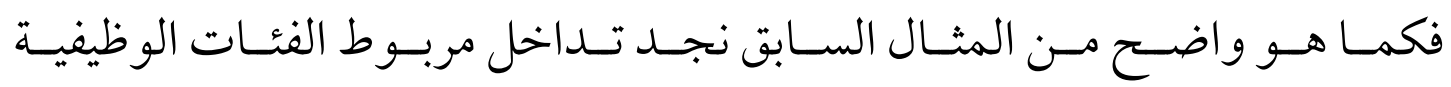
بعضـها بـبعض، وتحقـق هـذه الطريقـة مزايـا للمــوظفين، حيـث تهيـئ لهــم الفرصـة لزيـادة مُرتَبـة عنــدما لا تكــون هنـاك فرصـة لترقيـتهم إلى الفئـة الوظيفيـة الأعلىى، كمـا أنهـا تتحاشـى ضــرورة الزيـادة الضـخمة في المرتبـات عنــد الترقيـة للوظيفــة الأعلىى،

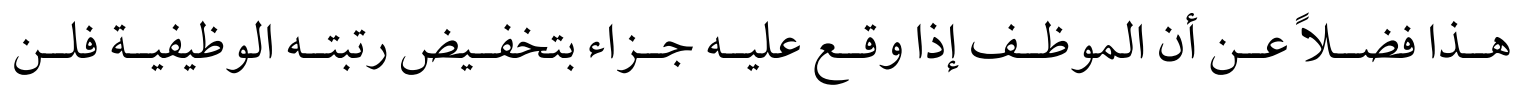
يحتاج الأمر إلى تخفيض مرتبه في نفس الوقت .

الطريقـة الثانيـة : المربـوط المـتلامس :- ويقصـــــهـا تلامسـس نهايـة مربـوط الفئسة الوظيفية مع بداية مربوط الفئة الوظيفية الأعلى منها ، مثال ذلك :

\begin{tabular}{|c|c|c|}
\hline \multicolumn{2}{|c|}{ المـــــــــــــــ } & \multirow[t]{2}{*}{ الفئة الوظيفية } \\
\hline نهاية المربوط & بداية المربوط & \\
\hline$\varepsilon 9$ & $\varepsilon$. & الرابعة \\
\hline rq & $r \cdot$ & الخامسة \\
\hline 19 & 1. & السادسة \\
\hline
\end{tabular}

ومسن هـذا المثـال يتضـح تميـز الفئـات الوظيفيـة المختلفــة عـن بعضهـا الـبعض،

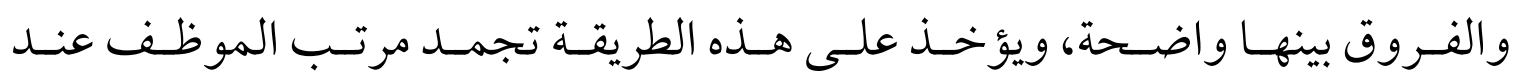
حد معين ، و لا يمكن زيادته إلا إذا رقى للفئة الأعلى .

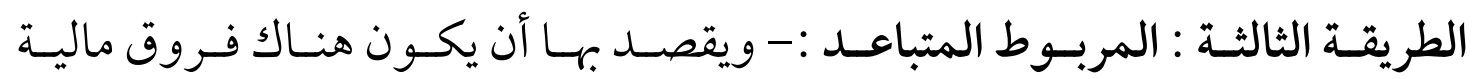
متباعدة بين بداية ونهاية مربوط الفئات الوظيفية المختلفة، مثال ذلك :

\begin{tabular}{|c|c|c|}
\hline \multicolumn{2}{|c|}{ 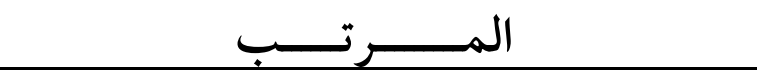 } & \multirow{2}{*}{ الفئة الوظيفية } \\
\hline نهاية المربوط & بداية المربوط & \\
\hline 0. & $\varepsilon \cdot$ & الرابعة \\
\hline ro & $r$. & الخامسة \\
\hline 10 & 1 . & السادسة \\
\hline
\end{tabular}


وواضح هنا تميز الفئات الوظيفية بعضها عن بعض بفروق واضحة من الناحية

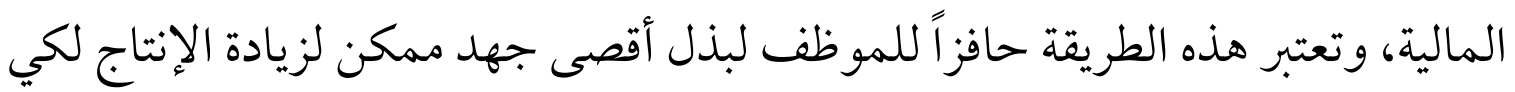

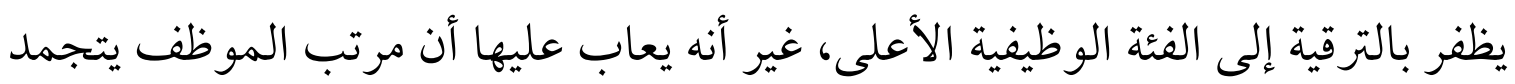
عند حد معين إذا لم يكن هناك فرصة للترقية).

الطريقة الرابعة: التقدير المستقل لكل وظيفة:- وتقوم هذه الطريقة على ربط مالي محدد لكل مستوى وظيفي، وعلى عكس الطرق السابق في تقدير الأجور والمرتبات، لم تضع هذه الطريق بداية مربوط للدرجة الوظيفية، ولا نهاية مربوط لها، بل يكون لكل درجة أو مستوى وظيفي مبلغنَّ مقطوعَّا، مثال ذلك:-

\begin{tabular}{|c|c|}
\hline المرتب & الفئة الوظيفية \\
\hline $1 \% \ldots$ & الرابعة \\
\hline $9 .$. & الخامسة \\
\hline $7 .$. & السادسة \\
\hline
\end{tabular}

وكما هو واضح من المثال السابق لم يحدد للفئة الوظيفية بداية ونهاية مربوط، إنما حُدد لكل فئة وظيفية مبلغَّا مستقلاً، ويشكل هذا المبلغ أساسي المرتب الذي يتم منح كافة المكافآت والبدلات بناءً عليه. كما يتضح الفرق الكبير في أساسي المرتب بين الفئات الوظيفية، وهذا يمثل دافعت كبيراً للموظفين لبذل قصارى جهدهم في أداء واجبات وظائفهم كي يظفروا بالترقية للفئة الأعلى. 
وقد أخذ قانون الخدمة المدنية المصري الحالي رقم 1 لسنة 7 ا • بم، عند تقديره للأجور بهذه الطريقة، فطبقًا للجداول أرقام(1) الوظائف إلى مجموعات، مجموعة الوظائف التخصصية، ومجموعة الوظائف الكتابية والفنية، ومجموعة الوظائف الحرفية والخدمية والمعاونة، قُسمت هذه المجموعات إلى مستويات وظيفية، وخُصص لكل مستوى درجة مالية معادلة، وأجر وظيفي ثابت شهريـا.

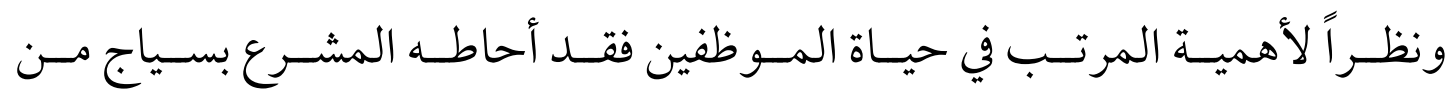

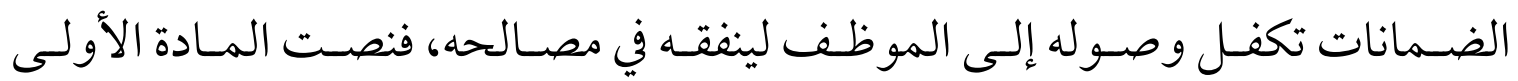

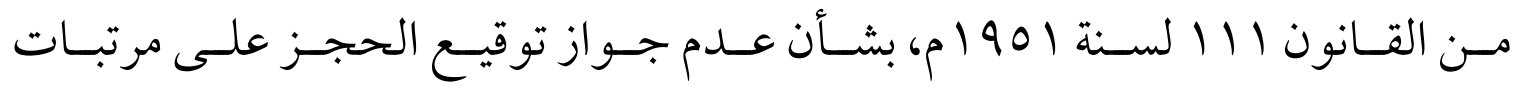

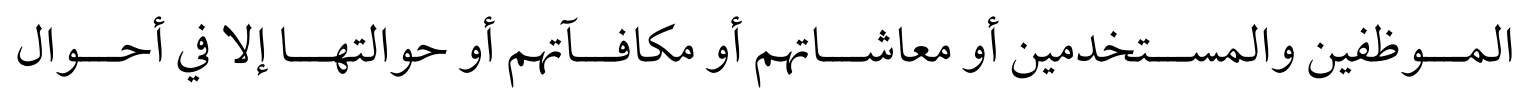
خاصة، و المعدلة بالقانون رقم سع لسنة ب797 ام على أنه : " لا يجــوز إجـــــاء خصـــم أو توقيـع حجــز علـى المبـالغ الو اجبــة الأداء مــن

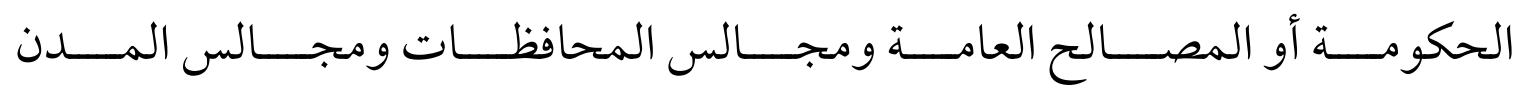

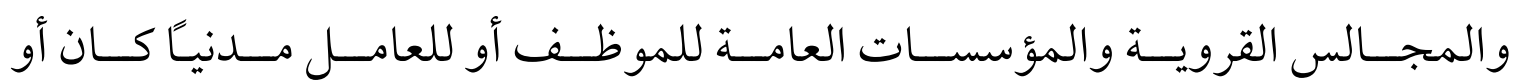

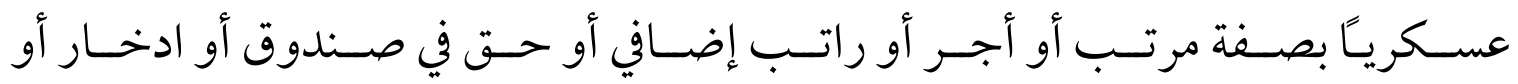
معـاش أو مكافـأة أو أي رصسيد مسن هـــه المبـالغ فيمـا يجـاوز الربـع، وذلـك لوفـاء

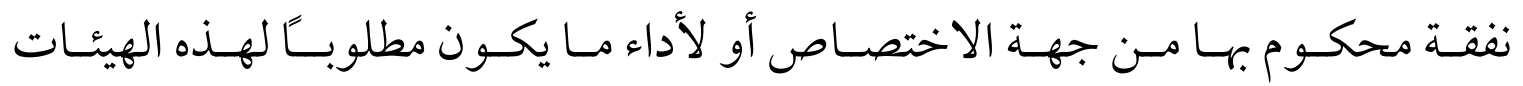

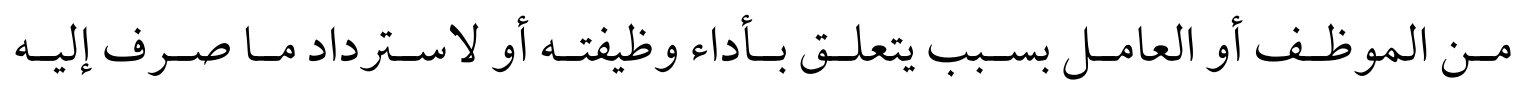
بغيـر وجـه حـق مـن المبـالغ المـذكورة أو بصـفة بــل سـفر أو اغـتراب أو بــل تمثيـل

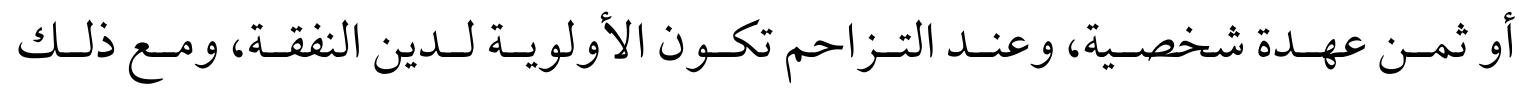




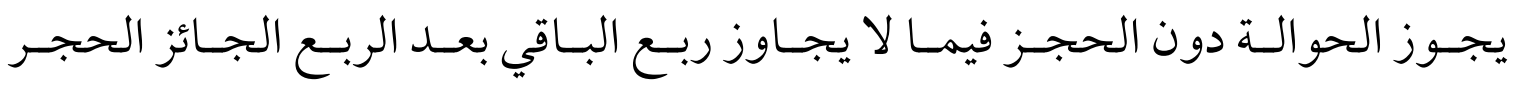

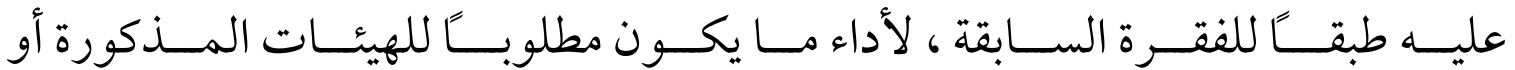

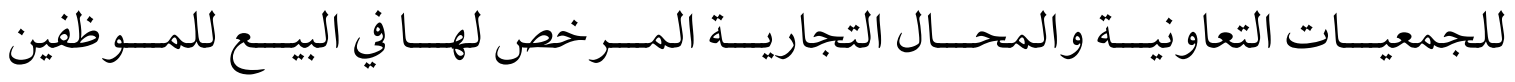

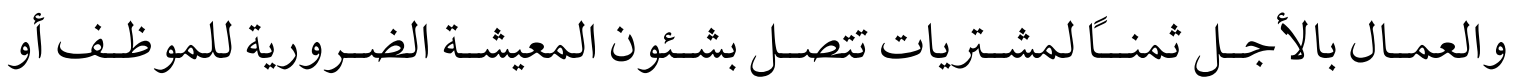

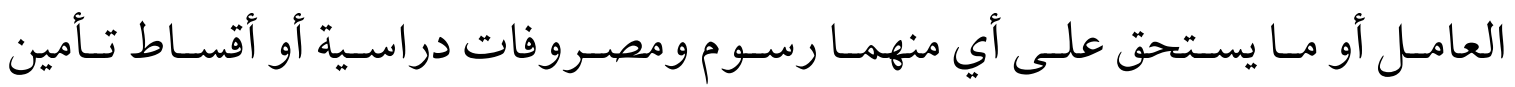

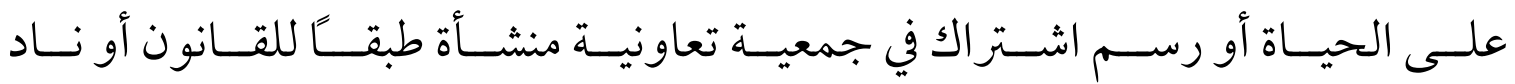

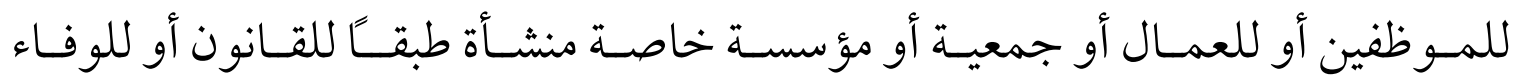

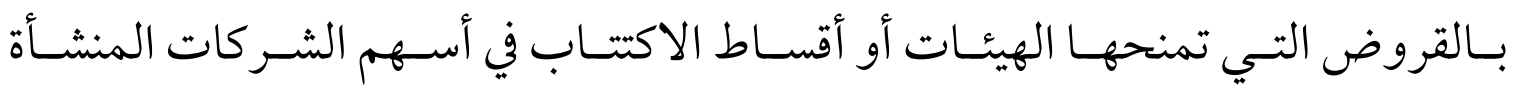

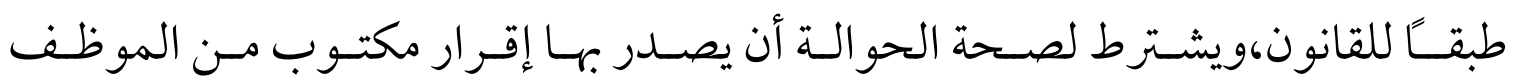

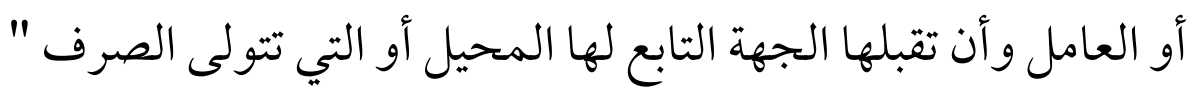
ومن ذلك يتضح مدى حرص المشرع على حماية المرتبات باعتبارها عصب الحياة بالنسبة للموظفين (1). وإذا كانت النظم الوضعية قد اهتمت بتوفير عائدٍ مناسبٍ للموظف العام يسد

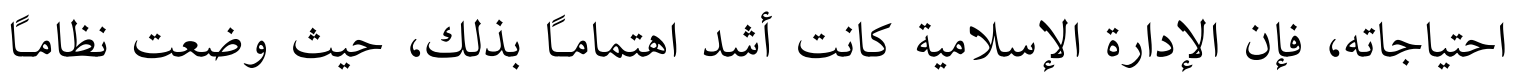

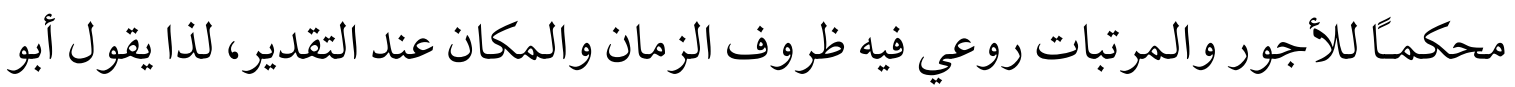
يعلى : "وأما تقدير العطاء -المرتب- فمعتبر بالكفاية "().

(1) وقد تضمن قانون الخدمة المدنية السوداني رقم ه لسنة بلو ام في مادته (11) نفس الحكم السابق لحماية المرتب وملحقاته المشار إليه في المتن ، أما المادة (·r) من نظام الخدمة المدنية السعودي ، فقد علقت بجواز الحجز على مرتب الموظف على إذن من السلطة المختصة فيما لا يجاوز ثلث صافي المرتب، ما عدا دين 
وقد راعت الإدارة الإسلامية عند تقدير المرتبات عدد من يعولهم الموظف من الأشخاص، وما يلزمه من إنفاق على ما يقنيه من الخيل والظهر، وما يلزم لتكاليف مظاهر الوظيفة وكل ما يتطلبه ذلك لأداء واجباتها على نحو أفضل، مع ضرورة مراعاة مستوى الأسعار في المكان الذي يوجد فيه الموظف من رخص أو غلاء، فيقدر كفايته في نفقته وكسوته لعامه كله فيكون هذا المقدر في أجره، ثم يعرض حاله في كل عام فإن زادت حاجاته الضرورية زيد في أجره (1). هذا عن أهم الأسس التي كانت توضع في الاعتبار عتد تقدير مرتبات الموظفين في الإدارة الإسلامية، أما عن طرق تقدير المرتبات، فلقد ضرب سيدنا عمر بن الخطاب-

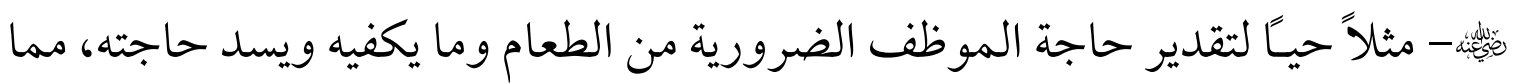
يعتبر وبحق من أحدث وسائل العصر الحديث في التقدير، وهو التقدير على الطبيعة،

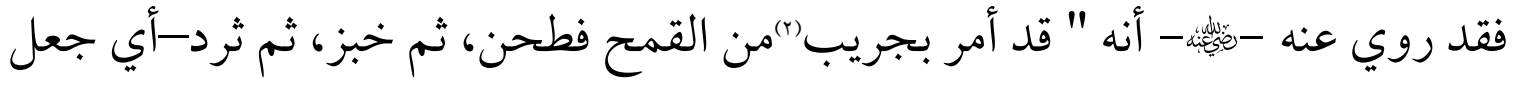
ثريداً- ثم دعا لأكله ثلاثين رجلاً، فأكلوا منه غداهم حتى أصدرهم -أي أشبعهم - ثم فعل في العشاء مثل ذلك، فقال عمر : يكفي الرجل جريبان في الشهر، -باعتبار أن للرجل أكلتان في اليوم- فكان يرزق الرجل والمرأة والمملوك جريبين كل شهر "(r).

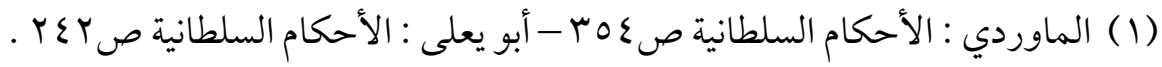
(r) الجريب : مكيال قدر أربعة أقفزة، والقفيز : مكيال كان يكال به قديمكا، ويعادل بالتقدير المصري الحديث نحو ستة عشر كيلو جرامًا ، إذا فالجريب يقدر بستين كيلو جرامًا.

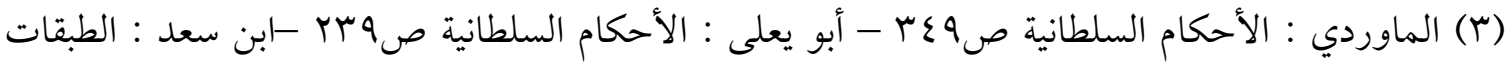

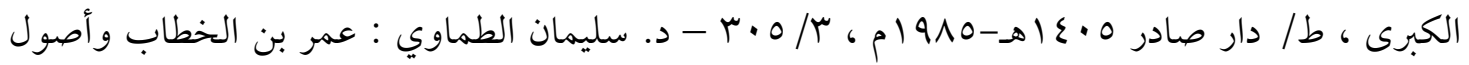

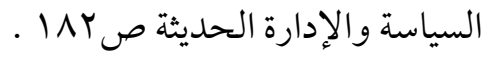




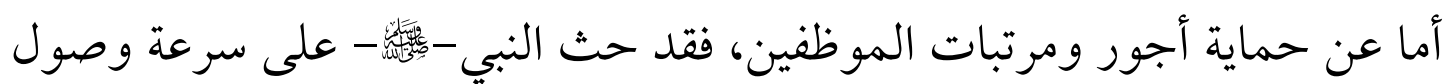
الأجر إلى العامل كاملاً دون أن ينقص منه شيئًا، حيث قال:" أعطو الأجير أجره قبل أن ستر

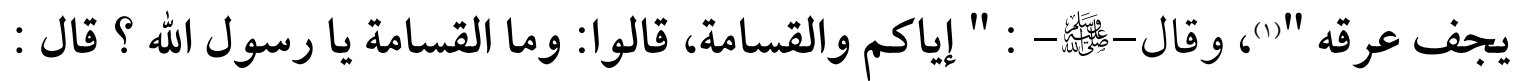
الرجل يكون على الفئام من الناس فيأخذ من حظ هذا وحظ هذا "(s). وبذلك كان للشريعة الإسلامية السبق في قيام سياسة الأجور على مراعاة مقدار الجهد الذي يبذله الموظف في أداء عمله، وخطورة العمل وأهميته من ناحية، ومن ناحية أخرى على ضرورة توفير الحد الأدنى على الأقل من حاجاته ومن يعول. بذلك نصل بفضل الله وكرمه إلى نهاية بحثنا الموسوم بدور الأجور الحافزة في تحقيق الرضا الوظيفي لدى الموظف العام دراسة مقارنة بالشريعة الإسلامية.

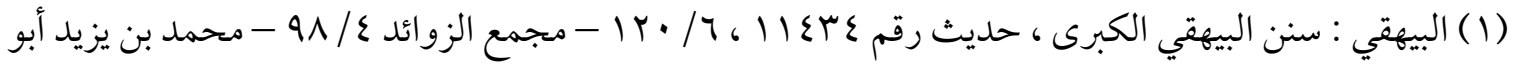

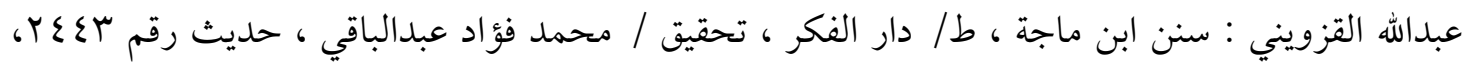
$. \wedge 1 v / r$

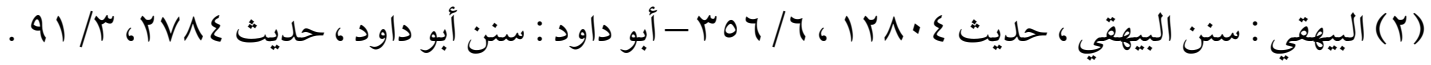




\section{الخاتمــة}

من خلال الاستعراض السابق الذي استهدفنا منه استكشاف نظرية تتعلق بالتقدير السليم للأجور والمرتبات تقوم على أسس موضوعية تحقق العدالة في توزيع تلك

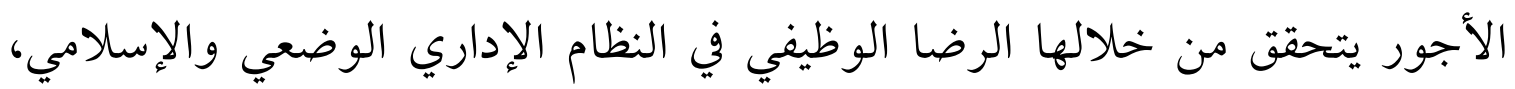
يمكن استخلاص النتائج والتوصيات الآتية: أولاً : النتائج المستخلصة من الدراسة :

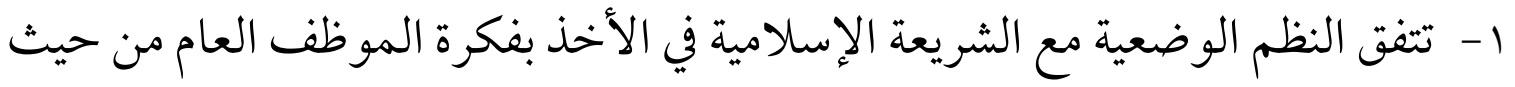

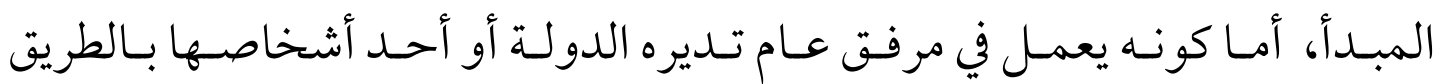
المباشر، وكون العمل الذي يقوم بـه دائمسكا، فهذه أمور لـم تكن تعرفها الشـريعة الإسلامية، غير أنه يترك تقديرها للسلطة العامة حسبما تقتضيه مصلحة الأفراد، ويمـا لا يتعـارض مـع القو اعـد الكلية والأصـول الشـاملة التي جـاءت بها الشـريعة

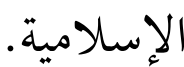

r- تتفق النظم الوضعية مع الشريعة الإسلامية بشأن مفهوم الرضـا الوظيفي، فالرضا الوظيفي هو عبارة عن مجموعة من الأحاسيس و المشاعر الكامنة داخل الموظف

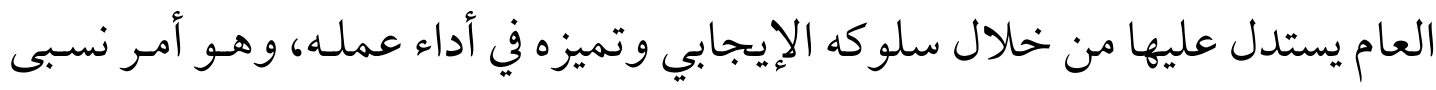
يختلف إلى حد كبير من موظف إلى آخر، والسبب في ذلك عدة عوامل مختلفة منها الظروف التي يعمل فيها الموظف؛ درجة طموحه ومدى تكيفه مع عمله؛ تعامله مع رؤسائه وزملائه؛ اشباع حاجاته؛ وتلبية رغباته، وعلى الرغم مـن أن الرضا نسبي لاختلاف العوامل المؤثرة فيه؛ إلا أنه يظل الراتب من أهـم، بـل أهـم عامل مؤثر في رضا الموظف العام عندما يكون مشبعَّ لحاجاته ومحققًَّا لرغباته وطموحاته. 
r- يتنوع الرضا الوظيفي إلى نوعين الأول: الرضا العام؛ وهـو الاتجاه العام للموظف نحو عمله ككل؛ من حيث كونه راضٍ عنه أم غير راضٍ؛ ولا يسمح هـذا المؤشر

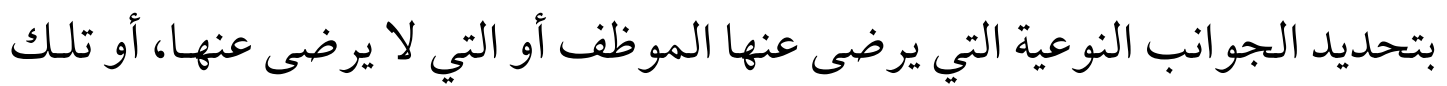

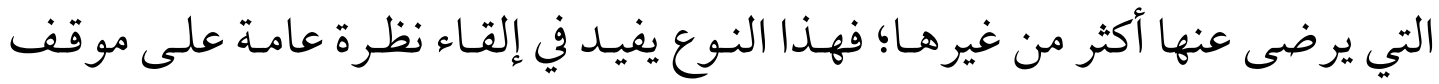
الموظف إزاء وظيفته · والنوع الآخر الرضا النوعي؛ ويشير إلى رضا الموظف عن كل جانب من جو انب عمله بشكل مستقل؛ وتتمثل تلك الجوانب في سياسية الادارة التي يعمل تحـت مظلتهـا؛ بمـا فيهـا المرتبـات؛ فرص الترقي؛ الرعايـة الصسحية والاجتماعية؛ وغير ها من علاقات العمل وبيئنه، وهذا النوع يفيد في تمكين الباحثين من الوقوف على العوامل التي تسهم في خفض الرضا أو زيادته. ع- تتفق النظم الوضعية مع الشريعة الإسلامية في أن تحقق الرضا الوظيفي لدى الموظف العام يؤدي إلى ارتفاع درجة الطموح لديه؛ مما يزيد من كفاءته في انجاز عمله؛ علاوة على ارتفاع الروح المعنوية لديه؛ الأمر الذي يدفعه إلى الإبداع والابتكار وتطوير ذاته؛ فالرضا الوظيفي يؤدي إلى تحقيق الأمن والاستقرار النفسي والفكري والوظيفي لدى الموظف العام؛ ويبعث روح الأمل والطموح لدى الموظفين الآخرين في الوصول إلى هذه الدرجة من الرضا الوظيفي، مما ينعكس تلوسي ذلك بالإيجاب على المؤسسة التي يعملون بها والمجتمع الذي يعيشون فيه • ه- تتعـدد العو امـل المؤثرة في الرضـا الـوظيفي إلى عوامـل شخصـية (ذاتية ) وعوامـل

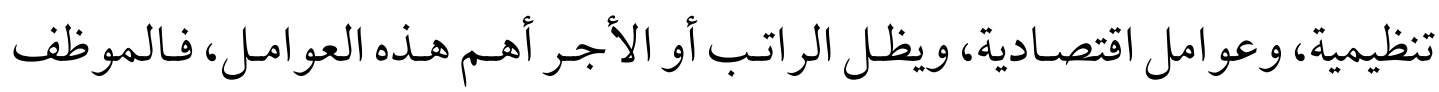
الر اضي عن راتبه تهون في نظره كل الصعاب وتغلب على كل المشاكل التي تحيط بأدائه لعمله، مهما بلغت من تعقيد. 
ז- اتفقت النظم الوضعية مع الشريعة الإسلامية بشأن أسس تقدير المرتبات، فكلا النظامين وضع في اعتباره أسس شخصية تتعلق بالموظف العام، وأسس موضوعية تتعلق بطبيعة الوظيفة العامة وصعوبة أدائها، غير أن النظم الوضعية كان لها السبق في ذلك، فضلاً عن أنها اتبعت طريقة تقدير عملية لمعرفة احتياجات الموظف، وذلك عندما قرر سيدنا عمر بن الخطاب رضى الله عنه بجريب من القمح فطحن، ثم خبز، ثم ثرد، ثم دعا لأكله ثلاثين رجلاً، فأكلوا منه غداهم حتى أصدرهم -أي أشبعرم ثم فعل في العشاء مثل ذلك، فقال عمر : يكفي الرجل جريبان في الشهر، -باعتبار أن

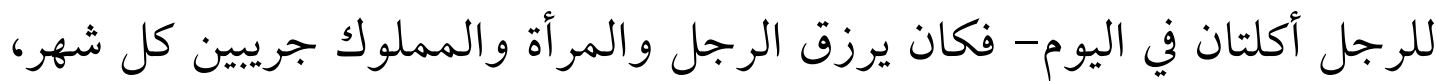
وهذا يمسى التقدير على الطبيعة تميزت به الشريعة الإسلامية وطبقه أمير المؤمنين عمر رضي الله عنه. وبذلك كان للشريعة الإسلامية السبق في قيام سياسة الأجور على مراعاة مقدار الجهد الذي يبذله الموظف في أداء عمله من ناحية، ومن ناحية أخرى على ضرورة توفير الحد الأدنى على الأقل من حاجته الماسة له ولمن يعول. v- اتفقت النظم الوضعية مع الشريعة الإسلامية، في أن الأجور الحافزة هي التي تسد حاجة الموظف ومن يعولهم، وتوفر هم حياة كريمة، وأن هذه الأجور تشتمل على لى لم مكونات مالية وغير مالية تراعي الجانب الإنساني والاجتماعي للموظف وأفرد أسرته.

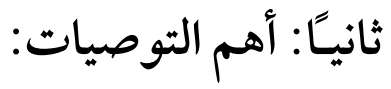
ويمكن بناءً على ما سبق اقتراح جملة من التوصيات من أهمها: 1- ضرورة إقرار مبدا المساواة في تولي الوظائف العامة، بحيث تكون متاحة للجميع إتاحة فعلية وليست على الأوراق، فالمو اطنون أما القانون سو اء. 
ץ- تبني أسس موضوعية لتقدير الأجور والمرتبات تطبق على الجميع، مراعى فيها المواصفات المطلوبة في الموظف وطبيعة الوظيفة ودرجة صعوبتها والمهارات

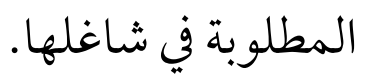

r- العدالة والمساواة في توزيع الدخل القومي، باعتبار أن هذا الدخل هو الذي تحدد على أساسه أجور ومرتبات الموظفين. ع - النظر بشكل دوري في مرتبات الموظفين بواقع مرتين أو مرة واحدة على الأقل في

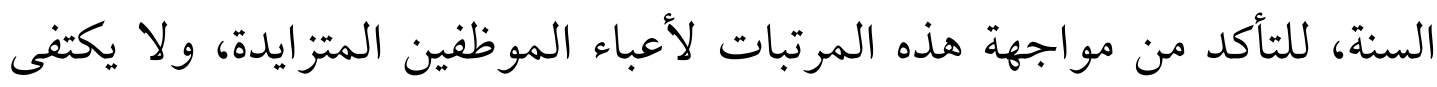
بتقرير علاوة دورية سنوية، لأن هذه العلاوة قد توقفها الإدارة لأنها لم تضاف إلى سلى المرتب قبل إقرارها. 0- وضع قانون موحد لمرتبات جميع الموظفين في الدولة، بحيث يتقاضى جميع الموظفين في الدولة مرتباتهم وفق هذا القانون. وهكذا نصل بفضل اله وتوفيقه إلى نهاية البحث، ولا أدعي أنني سددت أو قاربت، ولكن أزعم أني قد استفرغت الوسع، والله من وراء القصد، فهو حسبي وعليه تكالي ولا حول ولا قوة إلا بالله العلي العظيم . وصلى الله على سيدنا محمد وعلى آله وصحبه وسلم 


\section{قائمة بأهم مصادر البحث}

1 إبراهيم أبو شمله: مدى الرضا الوظيفي لدى موظفي بلديات المحافظة الوسطي،

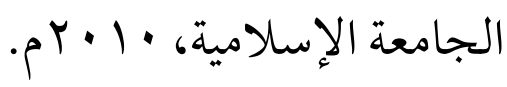

r- إبراهيم الباجوري: حاشية الباجوري على شرح ابن قاسم على متن الشيخ أبي

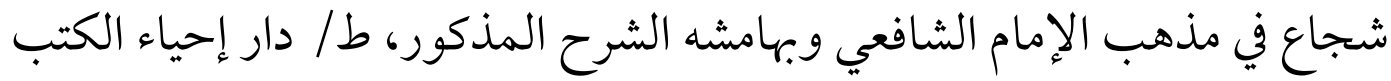

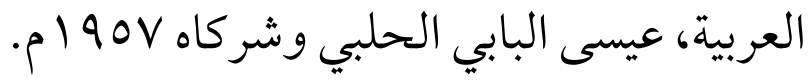

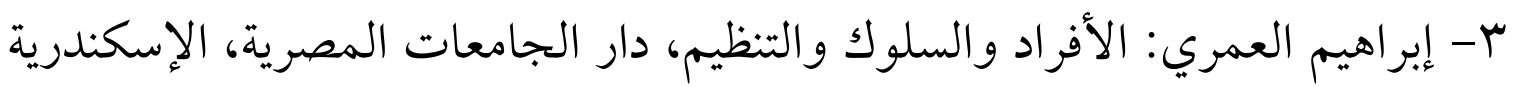
.$p 19 \vee 9$

ع - إبراهيم عبد الصادق محمود: الاختيار للوظيفة العامة في النظام الإسلامي دراسة مقارنة بالنظم المعاصرة، رسالة دكتوراه، مقدمة لكلية الشريعة والقانون

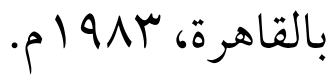
ه- ابن قدامة المقدسي: المغني والشرح الكبير، دار الكتاب العربي، بيروت، .

1- أبو الحجاج مسلم بن الحجاج القشيرى النيسابورى: صحيح مسلم : دار إحياء التراث العربى، بيروت، دار إحياء الكتب العربية، القاهرة، تحقيق / محمد فؤاد

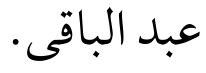
V أبو الحسن على بن محمد الشهير بالماوردى: الأحكام السلطانية والو لايات الدينية

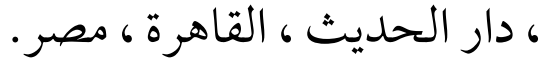

1- أبو الحسن نور الدين علي بن أبي بكر بن سليمان الهيثمي: مجمع الزوائد ومنبع

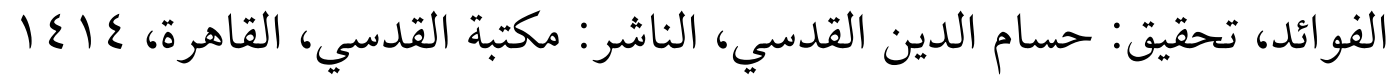
$.0199 \varepsilon$ 
9- أبو الحسين أحمد بن فارس بن زكرياء القزويني الرازي: مجمل اللغة لابن فارس، دراسة وتحقيق: زهير عبد المحسن سلطان، مؤسسة الرسالة - بيروت الطبعة

$$
\text { الثانية - } 7 \text { - أهـ - } 1917 \text { ام. }
$$

• - - معجم مقاييس اللغة، تحقيق، عبد السلام محمد هارون، دار الفكر، 94 با هـ .$p^{19 \vee 9}$

1 - أبو العباس أحمد بن محمد الفيومي : المصباح المنير في غريب الشرح الكبير؛

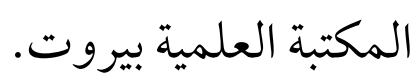

r أ - أبو الفرج جمال الدين بن علي بن محمد الجوزي: صحيح البخاري مع كشف بـف

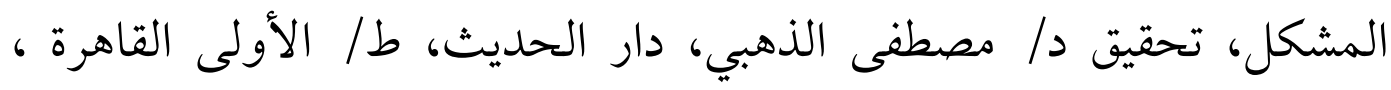
. $r \cdots-\infty) \leqslant r$. rا - أبو الفضل جمال الدين محمد بن منظور: لسان العرب، دار صادر، بيروت .$\rightarrow|\varepsilon| \varepsilon$

ع ا - أبو القاسم سليمان بن أحمد الطبري : المعجم الأوسط ، تحقيق / طارق عوض الله بن محمد ، عبدالمحسن بن إبراهيم الحسيني ، ط/ دار الحرمين ، القاهرة $.01 \leqslant 10$

10 - أبو بكر عبدالززاق بن همام الصنعاني : مصنف عبدالرزاق، تحقيق/ حبيب

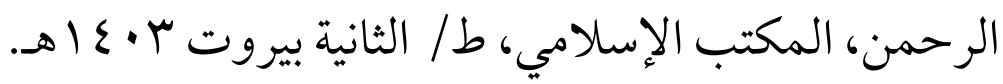
17 - أبو بكر محمد بن الحسن بن دريد الأزدي: جمهرة اللغة، المحقق: رمزي منير

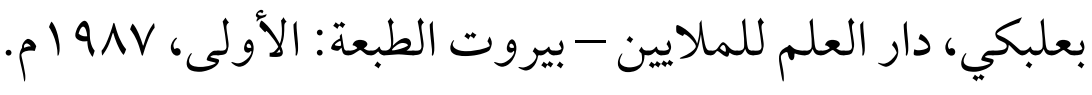

IV - أبو جعفر محمد بن جرير الطبري : تاريخ الطبري(تاريخ الرسل والملوك) تحقيق/ محمد أبو الفضل إبراهيم، دار المعارف، بدون تاريخ، ط / الرابعة . 
11 - أبو زكريا محي الدين يحيى بن شرف النووي: المنهاج شرح صحيح مسلم بن

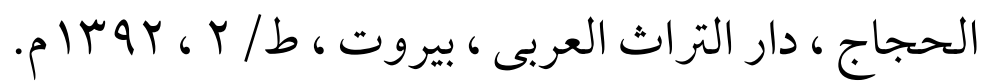

19 - : : روضة الطالبين، المكتب الإسلامي، 90 س1 هـ-9V0 ام . • • - أبو عبد الرحمن الخليل بن أحمد بن عمرو بن تميم الفراهيدي البصري: كتاب العين، المحقق: د مهدي المخزومي، د إبراهيم السامرائي، دار ومكتبة الهالال. ا ا - أبو عبد الله الحاكم محمد بن عبد الله بن محمد بن حمدويه بن نُعيم بن الحكم النيسابوري المعروف بابن البيع: المستدرك على الصحيحين، تحقيق: مصطفى

عبد القادر عطا، دار الكتب العلمية -بيروت، ط/ |، || |ع| - • 199 م.

r Y - أبو عبد الله محمد بن احمد شمس الدين القرطبي: الجامع لأحكام القرآن (تفسير القرطبي)، تحقيق / احمد البردوني وإبراهيم اطفيس، دار الكتب

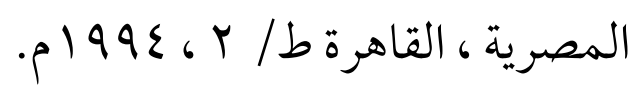

ץr- أبو عبداله محمد بن منيع البصري الزهري المعروف بابن سعد : الطبقات الكبرى ، دار صادر، و دار الكتب العلمية، 910 ام.

ع - - أبو عيسى محمد بن عيسى بن سَوْرة بن موسى بن الضحاك(الترمذي): الجامع الكبير - سنن الترمذي-، تحقيق: بشار عواد معروف، دار الغرب الإسلامي -

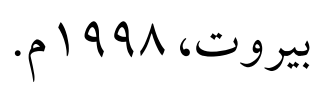

0Y - أبو منصور محمد بن أحمد بن الأزهري الهروي: تهذيب اللغة، المحقق: محمد عوض مرعب، دار إحياء التراث العربي - بيروت الطبعة: الأولى، ا + . rم. جr- أبو نصر إسماعيل بن حماد الجوهري الفارابي: الصحاح، تاج اللغة وصحاح العربية، تحقيق: أحمد عبد الغفور عطار، دار العلم للملايين - بيروت الطبعة:

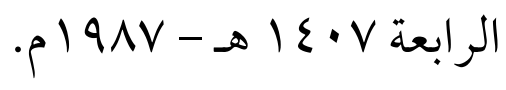


Y V أبو يحيى زكريا الأنصاري الشافعي : كتاب أسنى المطالب شرح روض الطالب،

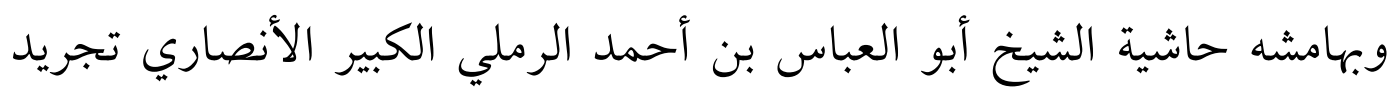

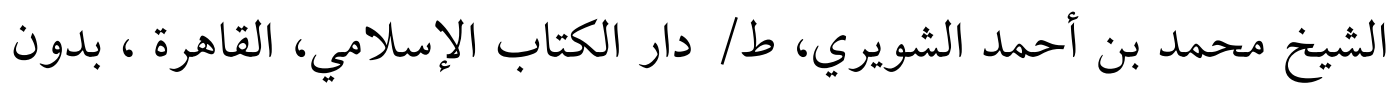

تاريخ.

^Y - أبو يوسف يعقوب بن إبراهيم الأنصاري : الخراج، تحقيق طه عبد الرؤوف، المكتبة الأزهرية.

qץ- أبوبكر محمد بن أبي إسحاق الكلاباذي البخاري : التعرف لمذهب أهل

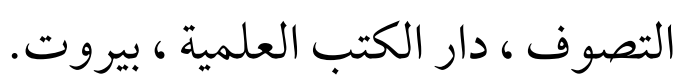

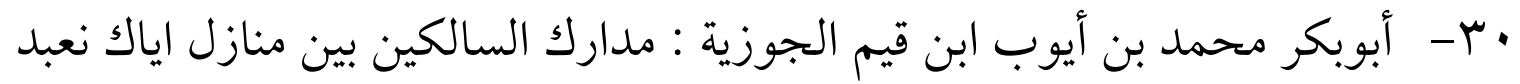

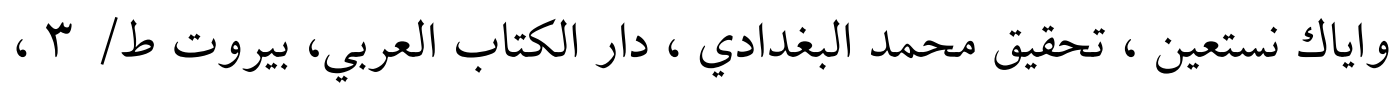
. 1997 اب- أبوبكر محمد بن أيوب ابن قيم الجوزية : مدارك السالكين بين منازل إياك نعبد

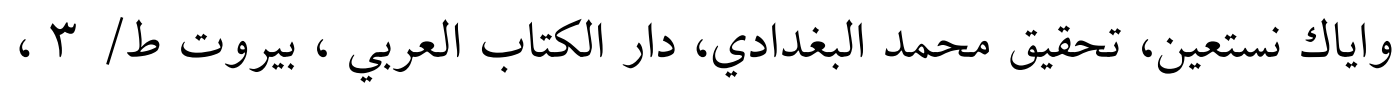
. 1997 r ب- أبوطاهر مجد الدين محمد بن يعقوب الفيروز أبادى: القاموس المحيط؛ مؤسسة

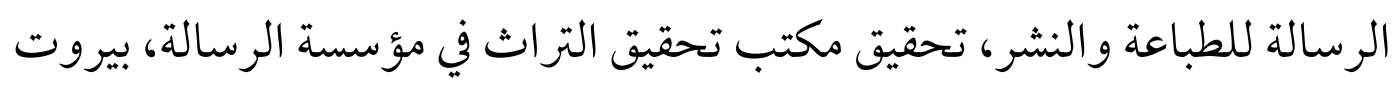

$$
\text { ط }
$$

rr- أبوعبد الله محمد بن عبدوس الجهشياري : الوزراء والكتاب، حققه ، مصطفي

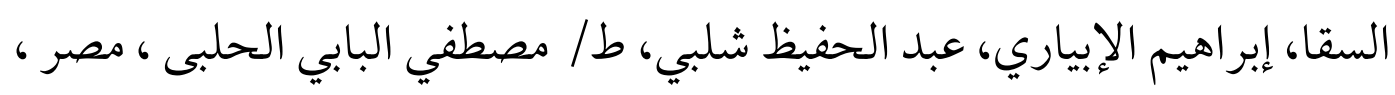
ط ع ب- أبوعبداله محمد بن يزيد القزويني : سنن ابن ماجة، ط/ دار الفكر، تحقيق/ محمد فؤاد عبدالباقي. 
هـ- أحمد بن الحسين بن علي بن موسى أبو بكر البيهقي : سنن البيهقي الكبرى ،

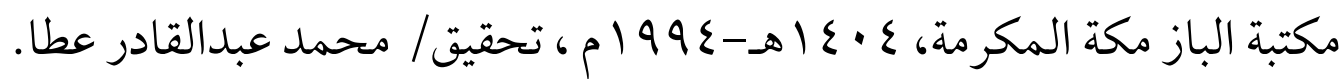
جس- أحمد بن حنبل أبو عبداله الشيباني: مسند أحمد، طبعة دار صادر، بيروت، بدون

$$
\text { تاريخ. }
$$

أب - أحمد بن عبدالحليم المعروف بابن تيمية : السياسة الشرعية في إصلاح الراعي و الرعية، المطبعة السلفية ومكتبتها، ط/ الثانية، القاهرة ، 99 ب1 هـ.

^ץ- أحمد صقر عاشور: إدارة القوى العاملة، الأسس السلوكية وأدوات الحفظ

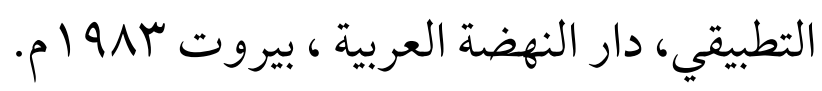

qس- أحمد فاضل عباس مكي: التطور التنظيمي في الجهاز المركزي للتنظيم والإداري، برامج القادة الإداريين، برامج الإدارة العليا، القاهرة 9V^ ام ـ •ع - أماني فهمي: العوامل المؤثرة في الرضا الوظيفي للقائمين بالاتصال في السينما المصرية خلال التسعينات، المجلة المصرية لبحوث الاعلام، القاهرة، 991 ام ، العدد سץ. اع - أندرو دي سيزلاي ، مارك جي والاس: السلوك التنظيمي ، ترجمة : أحمد أبو القاسم ، معهد الإدارة العامة ، الرياض السعودية ، 1991 1م. r ع - أنور رسلان : الوظيفة العامة، ط/ دار النهضة العربية، القاهرة ع 99 ام.

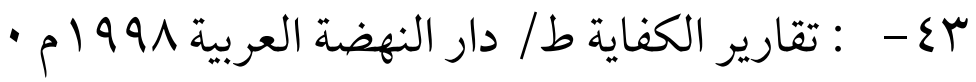
ع - إيمان جوده، ورنده الباقي: العلاقة بين البيروقراطية، ضغوط العمل، وعدم الرضا، دراسة حالة (مجلة العلوم الإدارية؛ جامعة الملك سعود؛ الرياض؛

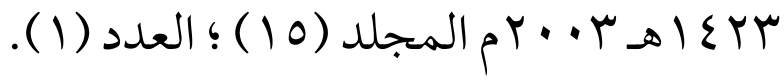
0ع- - إيمان عبد الباقي: العلاقة بين البيروقراطية وضغوط العمل، وعدم الرضا الوظيفي، دراسة حالة، مجلة العلوم الإدارية، جامعة الملك سعود، المملكة، 
7ع - إيناس فؤاد فلبمان: الرضا الوظيفي وعلاقته بالالتزام التنظيمي لدى المشرفين التربويين والمشرفات التربويات، بإدارة التربية والتعليم بمدينة مكة المكرمة،

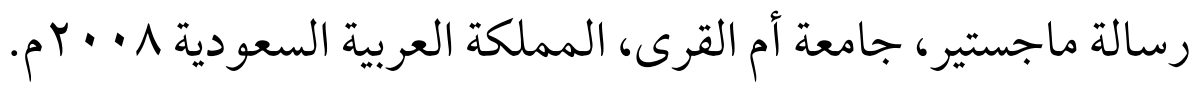
IV - بشرى عباس محمد: تأثير الرضا الوظيفي في الأداء المنظم، دراسة تحليلية في

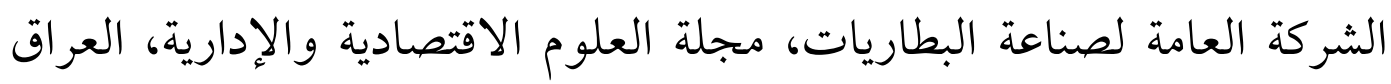

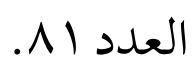

^乏 - - بوظريفه حمو ، دوقة أحمد ، لورسي عبد القادر: عوامل الرضا لدى أساتذة التعليم الثانوي دراسة ميدانية ، دار الطب الملكية للطباعة والنشر والتوزيع

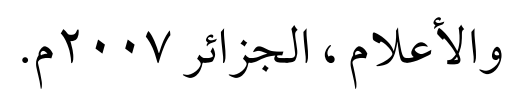

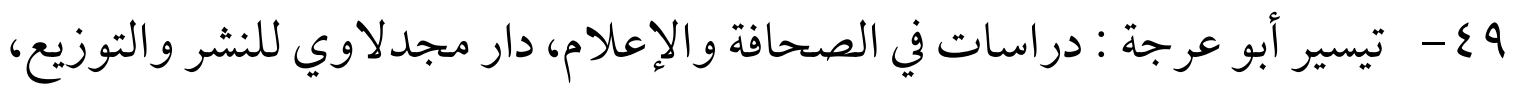

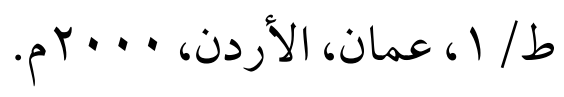

•- - جاسر صالح محمد الرفاعي: أثر المناخ التنظيمي على الرضا الوظيفي لدى

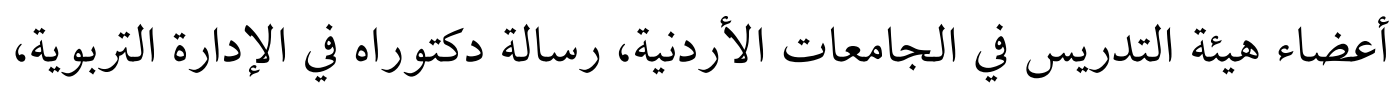

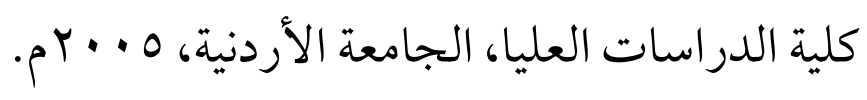

ا0- جرنبرج جيرالد ، بارون روبرت : ادارة السلوك ، ترجمة رفاعي رفاعي ،

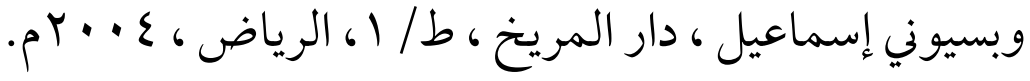

$$
\begin{aligned}
& \text { ror - الجريدة الرسمية لجمهورية مصر العربية. }
\end{aligned}
$$

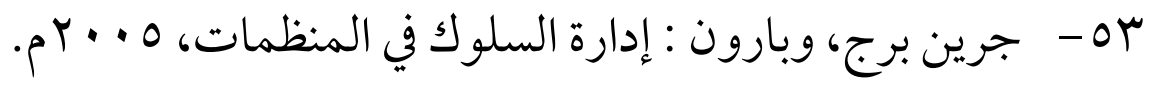

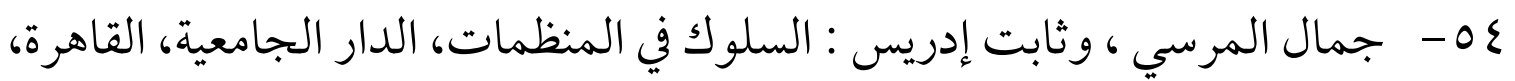

$$
\text { ץ. P }
$$

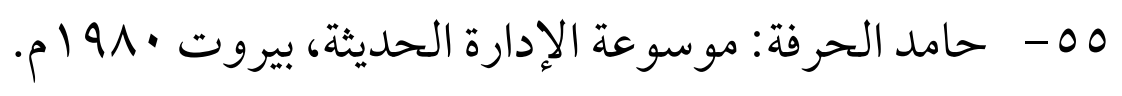


به - حامد بدر: الرضا الوظيفي لأعضاء هيئة التدريس والعاملين بكلية التجارة والاقتصاد ، و العلوم السياسية بجامعة الكويت مجلة العلوم الاجتماعية.

- OV الأعمال، دار الحامد للنشر والتوزيع ط/ ( ، عمان: الأردن ع + . بم.

1 - - حماد محمد شطا: النظام القانوني للأجور والمرتبات في الوظيفة العامة، ط/ p $19 \mathrm{VV}$

9ه- - حمدي أمين عبدالهادي : إدارة شئون موظفي الدولة أصولها وأساليبها، ط/ الثانية ، دار الفكر العربي، القاهرة ب1919

• - - الفكر الإداري الإسلامي والمقارن، دار الفكر العربي، ط/ الثالثة، بدون تاريخ. ال7- نظرية الكفاية في الوظيفة العامة دراسة الأصول العامة للتنمية الإدارية وتطبيقاتها المقارنة، رسالة دكتور اه مقدمة لكلية الحقوق جامعة القاهرة 977 (م، طبعة دار

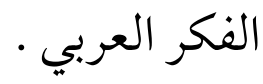

rا7- خالد محمد خالد: رجال حول الرسول، ط/ دار الفكر، بدون تاريخ. سج- خديجة مرشد: تأثير المادة الإعلانية في الصحف السعودية على الأداء المهني للصحفيين، رسالة ماجستير، جامعة الإمام محمد بن سعود الإسلامية،

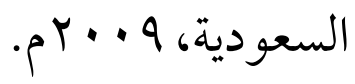

ع - خلف السيد: تنمية القدرات القيادية للعاملين بالجامعات، دار العلم والايمان،

$$
\text { كفر الشيخ، مصر 9 + • ب م. }
$$

07 - دينا يحيى: العوامل المؤثرة في الرضا الوظيفي للقائم بالاتصال في قنوات التليفزيون المحلية ، دراسة ميدانية ، مجلة البحوث الإعلامية ، العدد · r ، 
77- راشد طاحوس الجعيري الزعبي: مستوى الرضا الوظيفي لدى المشرفين التربويين في المنطقة الشرقية بالمملكة العربية السعودية من وجهة نظرهم، رسالة ماجستير، كلية الدراسات العليا : جامعة عمان العربية للدراسات العلمية

$$
\text { . } r \cdots T / r \cdots 0
$$

TV - راويه حسن : إدارة الموارد البشرية، رؤية مستقبلية، الدار الجامعية للطباعة

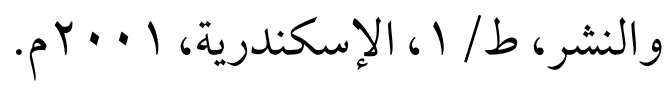

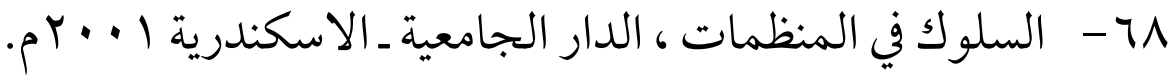
79- - رشيد زرواتي: تدريبات على منهجية البحث العلمي في العلوم الاجتماعية ، دار

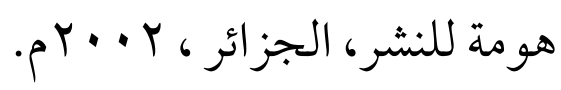

•- - رمضان محمد بطيخ: الوسيط في القانون الإداري، ط/ دار النهضة العربية، القاهرة 997 (م.

ا -V - زهيه عزبون: التحفيز وأثره على الرضا الوظيفي للمورد البشرى في المؤسسة

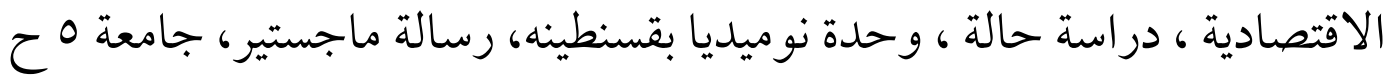

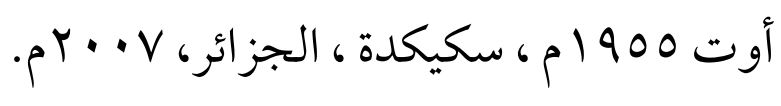



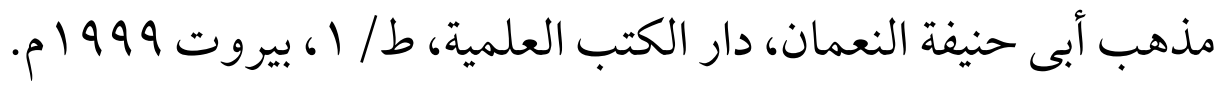
r

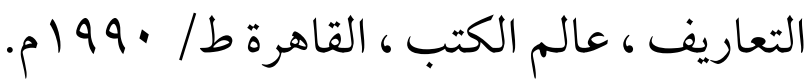
ع - - زين العابدين عبدالعزيز حسين السعدني : حوافز الموظفين بالدولة دراسة مقارنة بين نظام الدولة الإسلامية والنظم المعاصرة ، رسالة ماجستير مقدمة لكلية

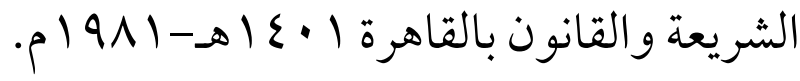


0- سالم تيسير الشرايده : الرضا الوظيفي أطر نظرية وتطبيقات عملية، دار الصفا

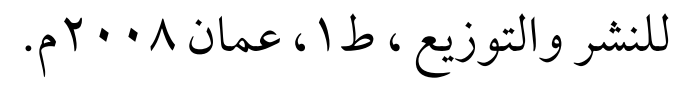

TT- سامى صليحة: المناخ التنظيمي وتأثيره على الأداء الوظيفي للعاملين ، دراسة حالة " أحمد بوقرة "بومرداس : رسالة ماجستير، جامعة أحمد بوقرة بومرداس،

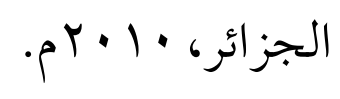

ساميه عدنان إبراهيم العجوري: العوامل المؤثرة في الرضا الوظيفي لدى -VV الصحفيات الفلسطينيات في فلسطين؛ دراسة ميدانية؛ رسالة ماجستير في كلية

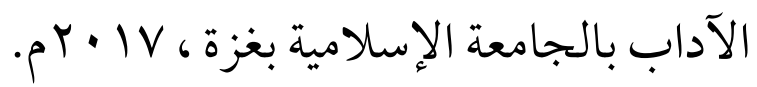

-VA سليمان بن الأشعث أبو داود السجستاني الأزدي: سنن أبي داود ، طبعة دار

$$
\text { الكتاب العربي، بيروت ، بدون تاريخ · ل }
$$

- Vq سليمان محمد الطماوي : عمر بن الخطاب وأصول السياسة والإدارة الحديثة دراسة مقارنة، دار الفكر العربي، ط/ الثانية، $9 V 7$ ام .

•^- - مبادئ القانون الإداري دراسة مقارنة ، الكتاب الثاني ، ط / دار الفكر العربي p $19 \vee 9$

1 ا - الأسس العامة لنظم الترقية والترفيع ، مجلة العلوم الإدارية ، العدد الثالث ، السنة السابعة ديسمبر 970 (1) - (1)

r r- الوجيز في القانون الإداري دراسة مقارنة، ط / دار الفكر العربي، القاهرة p $199 r$

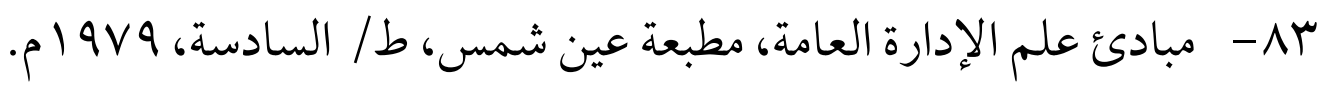
ع^- سهيلة محمد عباس: إدارة الموارد البشرية، مدخل استراتيجي، دار المسيرة

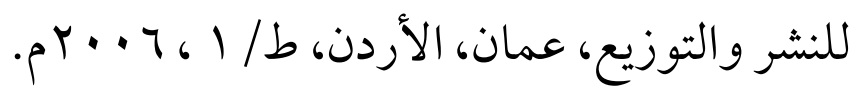


10- السيد خليل هيكل: القانون الإداري السعودي، مطابع جامعة الملك سعود،

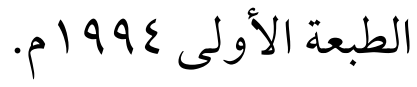

T1 - السيد طلبه السيد، محمود حسني الزيني : محاضرات في الفقه الشافعي ، ط/

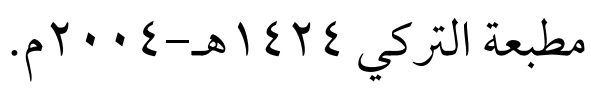

1VV - شمس الدين المقدسي أبو عبداله محمد بن مفلح : كتاب الفروع، راجعه/

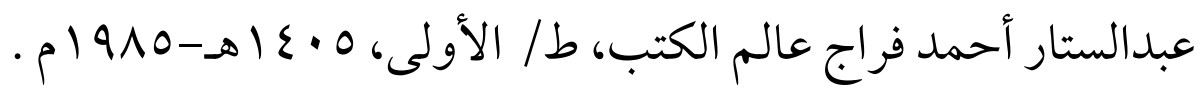
11- شهاب الدين أبو العباس الصنهاجي المعروف بالقرافي: الفروق ، مطبعة إحياء الكتب العربية، القاهرة ، جـ با هـ. 91 - صبري جلبي أحمد: النظم التقدمية في الوظيفة العمومية، دراسة مقارنة بين

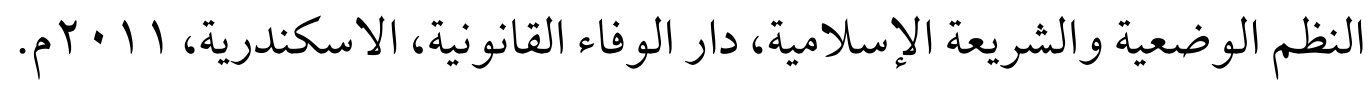
• - - صلاح محمد عبد اله: السلوك التنظيمي ـ مدخل تنظيمي معاصر، دار الجامعة

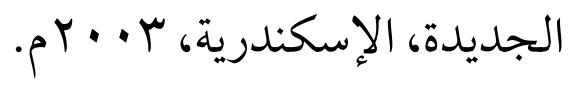

19- طريف شوقي فرج: السلوك القيادي وفعاليته الإدارية، دار غريب للنشر

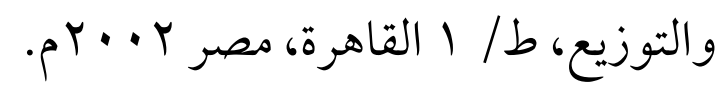

به- ظافر القاسمي : نظام الحكم في الشريعة والتاريخ الإسلامي، الكتاب الأول،

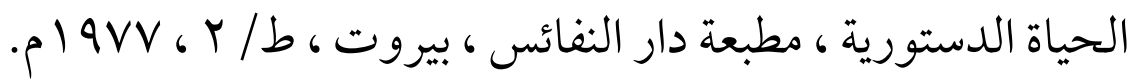

بهو- نظام الحكم في الشريعة والتاريخ الإسلامي، الكتاب الثاني السلطة القضائية ، ط/ دار النفائس، ط/ الثانية $9 V V$ ام.

ع9- عادل عبد الرازق هاشم : القيادة وعلاقتها بالرضا الوظيفي، ط/ دار البازوري،

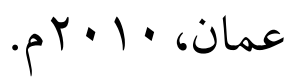


90- عارف بن ماطل الجريد: التحفيز ودوره في تحقيق الرضا الوظيفي لدى العاملين بشرطة منطقة الجوف، دراسة ميدانية على ضباط وأفراد شرطة منطقة الجوف، رسالة ماجستير كلية الدراسات العليا، جامعة نايف العربية للعلوم الأمنية السعودية. 97 - عبد الحليم بن عبد المجيد حكيم: الرضا الوظيفي لدى معلمي التعليم العام و معلمي الفئات الخاصة من الجنسين، دراسة مقارنة؛ رسالة ماجستير؛ جامعة أم

$$
\text { القرى، المملكة العربية السعودية؛ } 9 \text { • • ب م. }
$$

9V - عبد الحميد عبد الفتاح المغربي، وعبد العزيز بن سلطان العنقري: إدارة الموارد البشرية لمواجهة تحديات وبناء استراتيجيات القرن الواحد والعشرين، دار

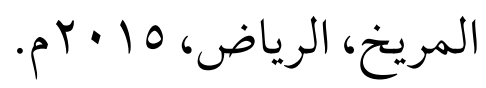

ه1 - عبد الله بن عبد الرحمن بن العزيز : تأسيس التقديس في كشف تلبيس داود بن جرجيس، مؤسسة الرسالة، تحقيق عبد السلام بن برجس العبد الكريم، ط/ 1،

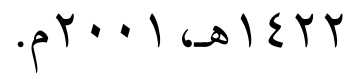

99 - عبدالحميد عبدالفتاح المغربي: دليل الإدارة الذكية لتنمية الموارد البشرية في

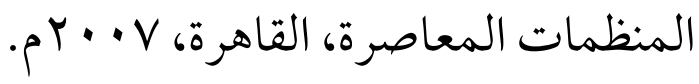

. . . - عبدالرحمن بن خلدون: مقدمة ابن خلدون الجزء الأول من كتاب العبر وديوان المبتدأ والخبر في أيام العرب والعجم والبربر ومن عاصرهم من ذوي السلطان

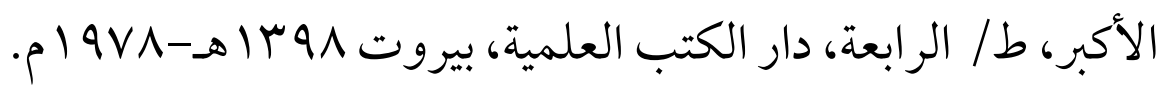

1 • 1 -عبدالعزيز حمد آل مبارك الإحسائي: تبيين المسالك شرح تدريب السالك إلى أقرب المسالك، شرح الشيخ محمد الشيباني بن محمد بن أحمد الشنقيطي الموريتاني، ط/ دار الغرب الإسلامي، ط/ الثانية 990 م. 
r + ا-عبدالعظيم عبدالسلام : القيادة الإدارية ودورها في صنع القرار، دار النهضة

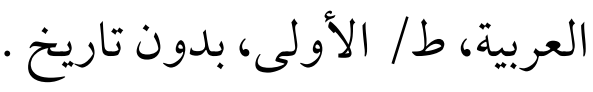

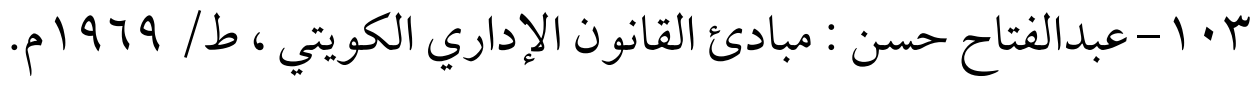
ع • ا- العبودي فاتح : الضغط النفسي وعلاقته بالرضا الوظيفي ، رسالة ماجستير ،

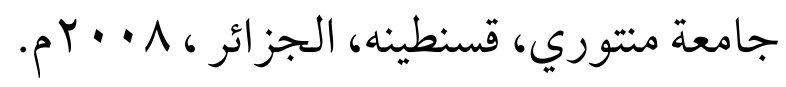
ه 1 - عدد من المختصين بإشراف الشيخ صالح بن عبد الله بن حميد إمام الحرم المكي: نضرة النعيم في مكارم أخلاق الرسول الكريم صلى الله عليه وسلم، ط/ ع عار الوسيلة للنشر، جده.

7 • 1 - عدلي خليل : التعليق على نصوص قانون نظام الموظفين بالقطاع العام، المكتبة

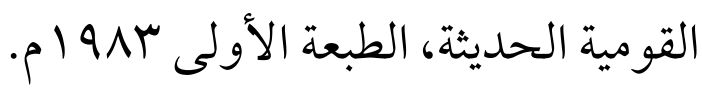

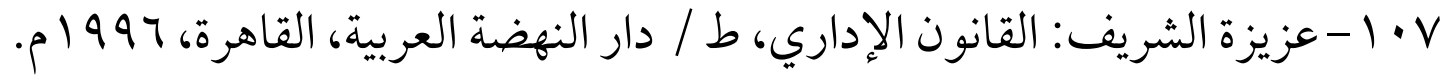

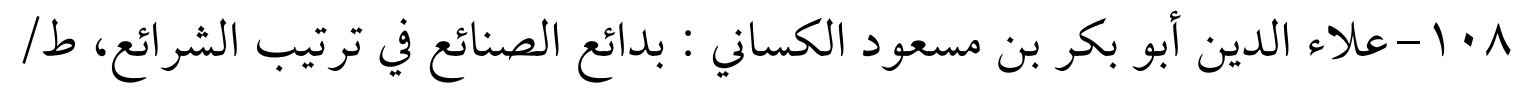

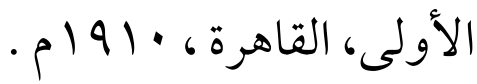

9. 1-على مرشد: أثر الحوافز في الرضا الوظيفي في الشركات الصناعية العاملة في منطقة الملك الحسين بن طلال التنموية في المفرق، رسالة ماجستير جامعة آل

$$
\text { البيت ؛ ع إب إم. }
$$

•11 - علي السلمي: الإدارة المصرية، رؤية جديدة، ط/ الهيئة المصرية العامة للكتاب .$p 19 \vee 9$

111 - 11 علي بن محمد الجرجاني : كتاب التعريفات، دار الكتب العلمية، ط/ الأولى

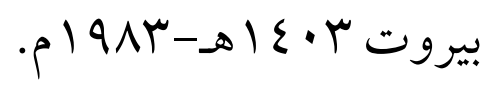


r ا ا - علي عبد القادر مصطفي: الوظيفة العامة في النظام الإسلامي وفي النظم الحديثة،

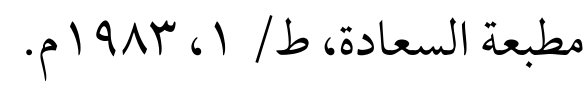

سا1ا-عليّ فالح المطيري: أثر المناخ التنظيمي في الرضا الوظيفي لدى العاملين في البنوك التجارية في دولة الكويت؛ رسالة ماجستير في كلية الأعمال جامعة عمان

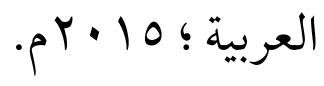

ع || - عمر حلمي فهمي: مبدأ الجدارة في تولية الوظائف العامة، طبعة مكتبة عين

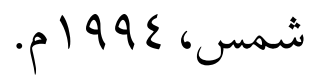

10 الارشادية، دكتور اه جامعة محمد الخامس، الرباط ع ا • بم. 117 - فتوح محمد عثمان: أصول القانون الإداري، طبعة / 919 (م. IV - الفضل محمد بن الأعرج: تحرير السلوك في تدبير الملوك، تحقيق ودراسة د/ فؤاد عبد المنعم أحمد، مؤسسة شباب الجامعة للطباعة و النشر و التوزيع. 11ا - فهد الخشاب: أثر الرضا في الارتباط الوظيفي لدى العاملين في رئاسة الوزراء لدولة الكويت، ماجستير جامعة آل البيت. 19 ا - فؤاد العطار : القانون الإداري ، ط / الثالثة ، ط/ بدون تاريخ أو ذكر . • با - القاضي أبو يعلى محمد بن الحسين بن الفراء : الأحكام السلطانية للفراء ،

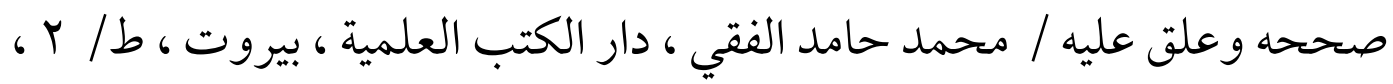

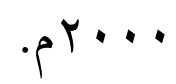

| ا | - القاضي عبداله بن عمر البيضاوي: الغاية القصوى في دراية الفتوى، دراسة وتحقيق وتعليق علي محي الدين علي القرة داغي، ط/ دار الإصلاح للطبع والنشر والتوزيع، السعودية، بدون تاريخ. 
r ا ا - كاظم خضير حمود: السلوك التنظيمي، دار الصفاء للنشر والتوزيع ، طا عمان ،

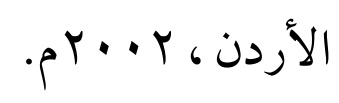

بrا - كامل المغربي: السلوك التنظيمي، مفاهيم وأسس سلوك الفرد والجماعة في التنظيم، دار الفكر للطباعة والنشر والتوزيع، طب، عمان، الأردن.

ع ז ا-كمال الدين محمد بن عبد الواحد السواسي ثم السكندري المعروف بابن الهمام الحنفي : شرح فتح القدير على الهداية شرح بداية المبتدي لشيح الإسلام برهان الدين على بن أبي بكر المرغيناني ومعه شرح العناية على الهداية للإمام أكمل الدين محمد بن محمود البابرتي وحاشية المحقق سعد الله بن عيسي المفتي الشهير بسعد جلبي وبسعد أفندي ويليه تكملة شرح فتح القدير المسماة نتائج الأفكار في كشف الرموز والأسرار لشمس الدين أحمد المعروف بقاض

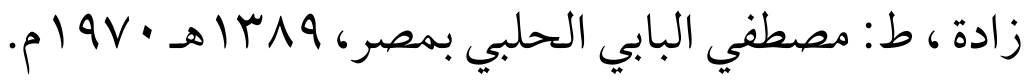
هY ا - ليندى بن سهل : الحوافز وعلاقتها بالرضا الوظيفي دراسة ميدانية مطبقة على

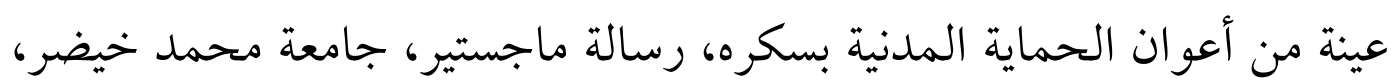

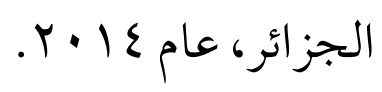

4Y I - ماجد راغب الحلو: القانون الإداري، ط / دار المطبوعات الجامعية، 9AV ام.

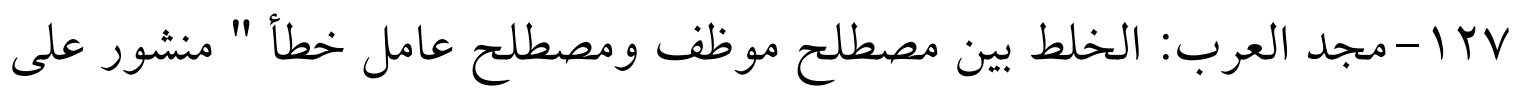
الإنترنت، شبكة القانون، موقع مجالسنا.

1Y1-مجدي مدحت النهري: الموظف العام، ط / دار النهضة العربية، القاهرة .$p 1997$

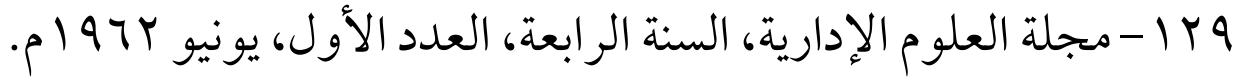




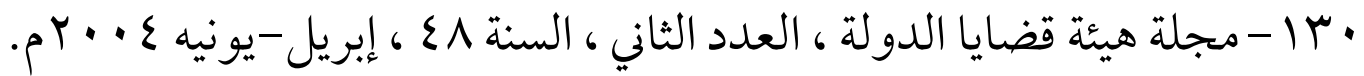
آسا - مجلس الدولة المصري: مجموعة المكتب الفني لمجلس الدولة، السنة الرابعة

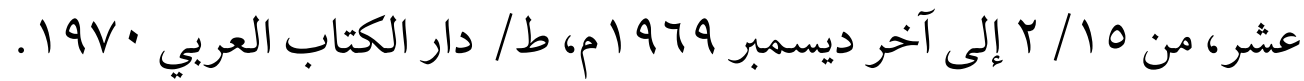
ץسا -مجمع اللغة العربية: المعجم الوجيز، طبعة خاصة بوزارة التربية والتعليم، . $199 r-\infty 1 \leqslant 1 r$ بrا - مجمع اللغة العربية: المعجم الوسيط، مكتبة الشروق الدولية، ع • • م. ع ا - مجموعة مجلس الدولة لأحكام القضاء الإداري، السنة السابعة. هبر - محسن على كتبي: السلوك التنظيمي بين النظرية والتطبيق، المكتبة الأكاديمية

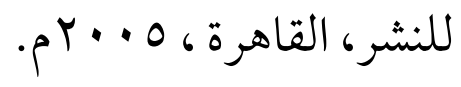
جسا - محمد إبراهيم التويجري: المواقف الوظيفية والرضا الوظيفي للعاملين من السعوديين وغير السعوديين في الشركات متعددة الجنسيات، دراسة ميدانية مقارنة "المجلة العربية للإدارة المجلد 9 1 ؛ العدد ب ؛ 999 1م. VV I - محمد إبراهيم حسن علي: مبدأ المساواة في تقلد الوظائف العامة دراسة مقارنة، رسالة دكتور اه مقدمة لكلية الحقوق، جامعة القاهرة ع1911910، 19. ^ץ| - محمد أحمد عادل: نحو نظام للأجر العادل في مصر، بحث منشور في مجلة مصر المعاصرة، تصدرها الجمعية المصرية للاقتصاد السياسي والاحصاء والتشريع، العدد ا YYO ، السنة المائة وسبعة، يناير 17 • ب م. qسا - محمد إسماعيل مرعى: الحقوق الدستورية في النطاق الوظيفي بين الشريعة الإسلامية والتشريعات الوضعية، مقدمة لكلية الشريعة والقانون بالقاهرة 
•عا - محمد الرضى بن الحسن الموسوي : نهج البلاغة من كلام الإمام علي، شرح

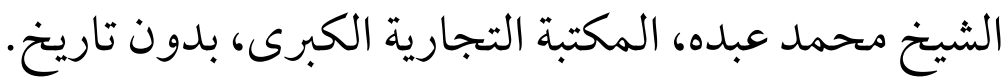

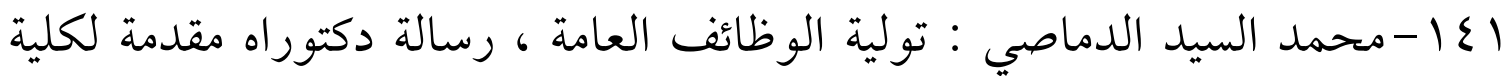

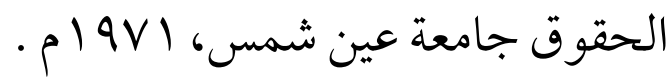

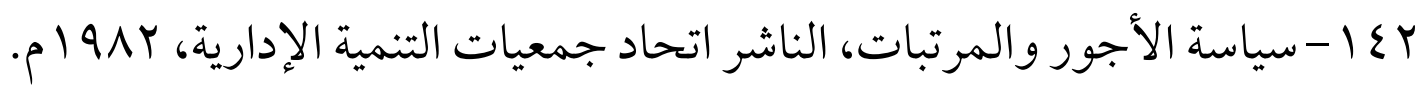

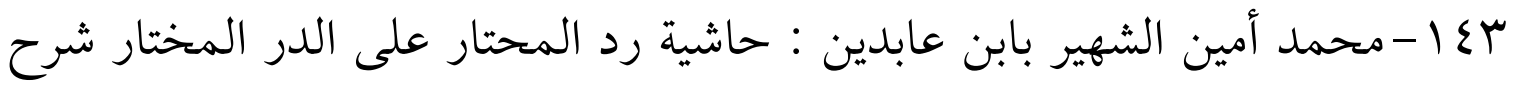

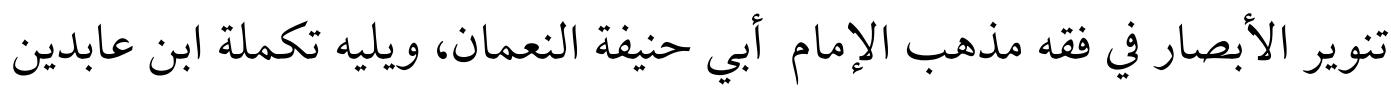

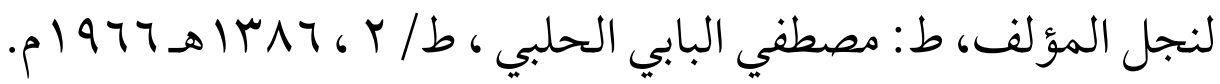

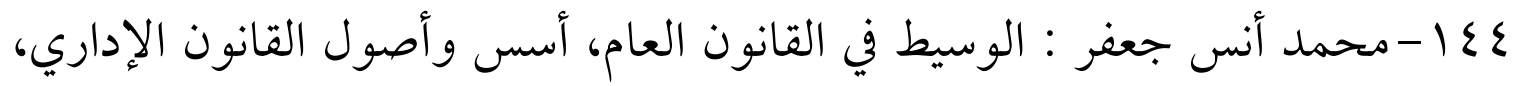

$$
\text { ط/ إخوان مورافتلي. }
$$

0ع ا-نظم الترقية في الوظيفة العامة، وأثرها في فاعلية الإدارة، دار النهضة العربية،

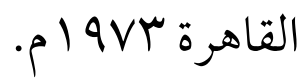

7ع ا - مبادئ الوظيفة العامة وتطبيقاتها على التشريع الجزائري، ط/ إخوان مورافتلي م 1914

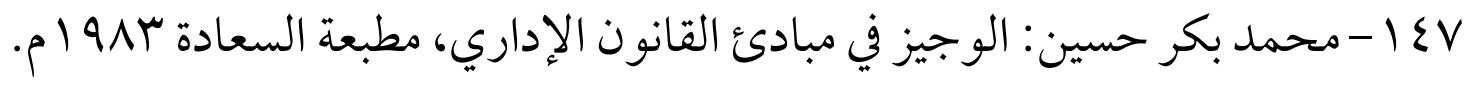

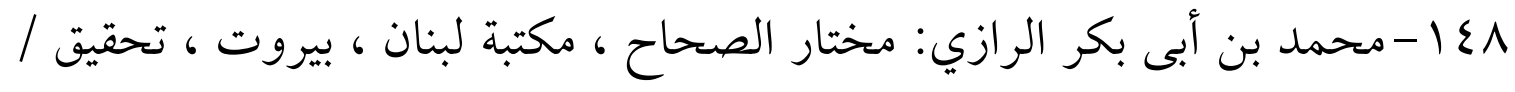

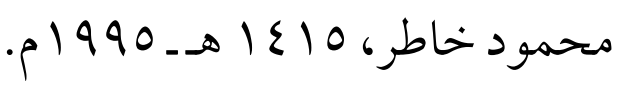

\§ ا-محمد بن أحمد شمس الائمة السرخسي: المبسوط، دار المعرفة، بيروت

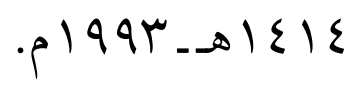

• 10 - محمد بن إسحاق بن خزيمة أبو بكر السلمي النيسابوري : صحيح ابن خزيمة،

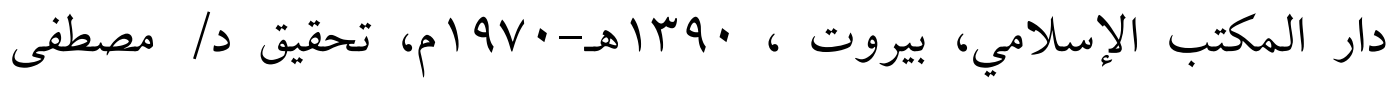

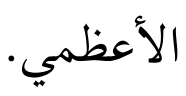


101 - محمد بن إسماعيل أبو عبداله البخاري الجعفي : صحيح البخاري، دار ابن

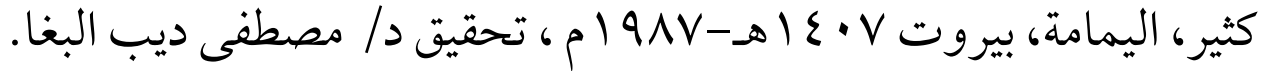
Yo 10 - محمد حامد الجمل الموظف العام بأنه: الموظف العام فقهًا وقضاءً، ط/ ب، دار النهضة العربية، القاهرة 979 1م.

به - محمد حسين هيكل: الفاروق عمر، دار المعارف بمصر، ط/ السادسة، بدون تاريخ. ع ا - محمد زين العابدين عبد الفتاح: درجة الرضا الوظيفي لدى أعضاء هيئة التدريس العاملين بشركات التعليم والتدريب مشتملة للسنة التحضيرية ـ جامعة تبوك

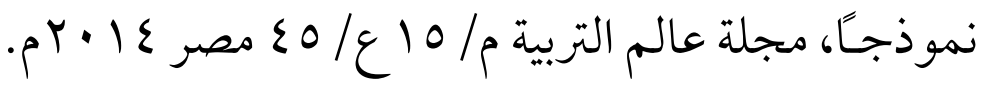
100-محمد سعيد سلطان: السلوك التنظيمي، دار ا لجامعة الجديدة، ط/ الإسكندرية، مصر، ع • ( ب م.

107-محمد صلاح الدين عبد الباقي: السلوك التنظيمي، الدار الجامعية للنشر و التوزيع، الإسكندرية.

loV - محمد عافت شافان العنزي: أثر الحوافز في تحقيق الرضا الوظيفي في المؤسسة العامة للتأمينات الاجتماعية في دولة الكويت، رسالة ماجستير في الإدارة العامة،

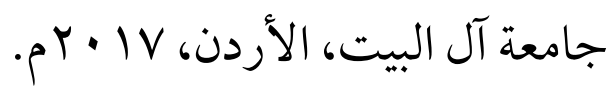
101 - محمد عبد الله الشباني: الخدمة المدنية على ضوء الشريعة الإسلامية مدخل

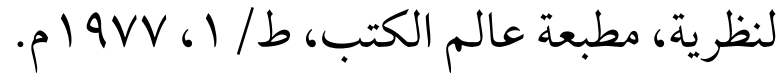
109 - محمد عرفة الدسوقي : حاشية الدسوقي على الشرح الكبير للدرديري، مطبعة

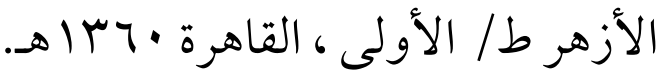


• 17 - محمد فؤاد مهنا: مبادئ و أحكام القانون الإداري، مطبعة الشاعر، بدون تاريخ. ا |7 - سياسة الإصلاح الإداري وتطبيقاتها في ضوء مبادئ علم التنظيم والإدارة، دار المعارف، مصر $19 V 1$ (م.

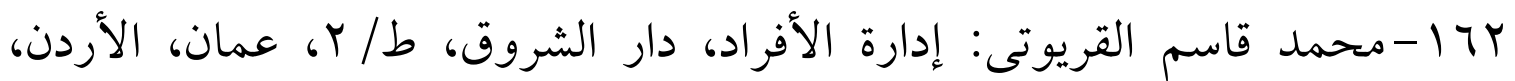
$\cdot p 199$. سجا -محمد كرد على: الإسلام والحضارة العربية؛ دار الكتب العلمية؛ القاهرة p) 947

ع7 ا-محمد ماهر حمادة : الوثائق السياسية والإدارية العائدة للعصر العباسي الأول دراسة ونصوص، مؤسسة الرسالة، ط/ الأولى، بيروت 99 بـ اهـ-9V9 ام. 170 - محمد نصر الدين محمد عويضه: فصل الخطاب في الزهد والرقائق والآداب، أعده للمكتبة الشاملة: الغريب الشهري.

77 ا - محمد يوسف الكاند هلوي: حياة الصحابة، علق عليه وخرج أحاديثه د/ محمد بكر إسماعيل، ط/ دار الحديث، المكتب الثقافي، القاهرة، ط/ الأولى $.01999-81 \varepsilon r \cdot$ ITV - محمود حلمي مصطفى: نظام الموظفين المدنيين بالجهاز الإداري والقطاع

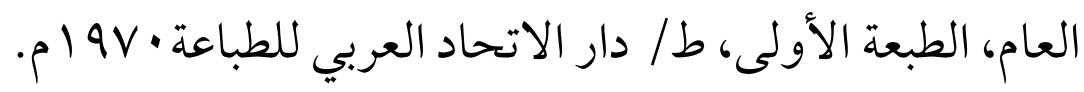
17 ا-محمود سلمان العميان: السلوك التنظيمي في منظمات الأعمال، دار وائل للطباعة والنشر، عمان، الأردن، ؟ +. ب م. 79 - 19 - محمود عاطف البنا : دراسات في الوظيفة العامة في النظام الفرنسي، بدون تاريخ

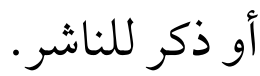


IV· مححمود مختار محمد منصور: نحو ترشيد سياسات الأجور والمرتبات في قطاع الدولة في مصر، المؤتمر العلمي السنوي الثامن للاقتصاديين المصريين: دور الدولة في النظام الاقتصادي المختلط، الذي أقامته الجمعية المصرية للاقتصاد السياسي والإحصاء والتشريع، في مايو بر91ام. |V| - مروان أحمد حويجي: أثر العوامل المسببة للرضا الوظيفي على رغبة العاملين

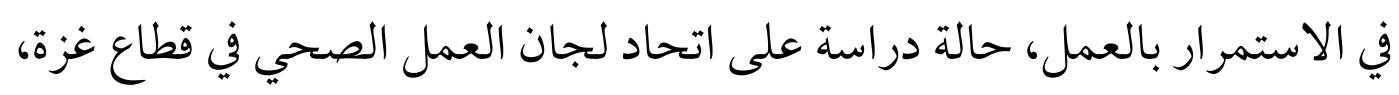

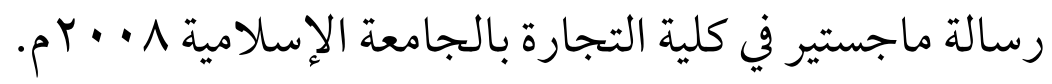

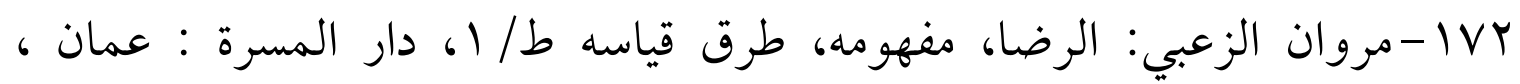
pr.l.

س ا - مصطفى أبو زيد فهمي : الوجيز في القانون الإداري ، ط/ $190 \mathrm{~V}$ IVE - مصطفي عشوي: أسس علم النفس التنظيمي، المؤسسة الوطنية للكتاب،

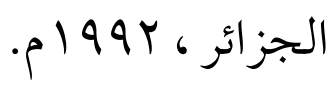

IV0 - مصطفي كامل وسونيا البكري : دراسات تحليلية للرضا الوظيفي لأعضاء هيئة

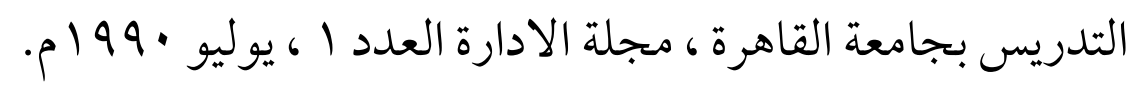
IV7 - مناحي مسلم القحطاني : الشفافية الإدارية ودورها في تحقيق الرضا الوظيفي

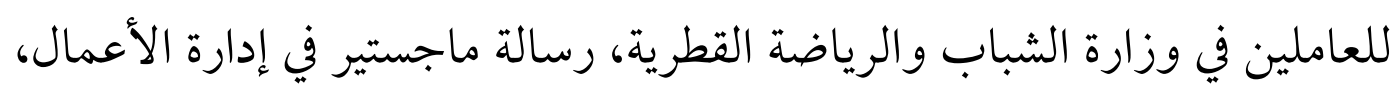

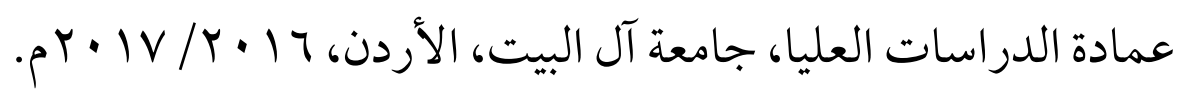
- IVV وتعليق الشيخ هلال مصيلحي، مصطفي هلال، دار الفكر للطباعة والنشر والتوزيع. 
IVA المؤسسات الإمار اتية؛ مجلة العلوم الإنسانية والاجتماعية العدد 19. IV9 -ناصر العديلي: السلوك الإنساني والتنظيمي، معهد الادارة العامة، الرياض p 1990

•11-نبيل رسلان : الحوافز في قوانين الحكومة والقطاع العام •ط / دار النهضة

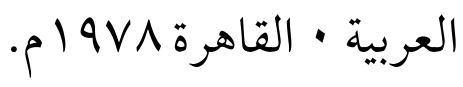

|11-نور الدين شنوفي: تفعيل تقييم أداء العامل في المؤسسة العمومية الاقتصادية،

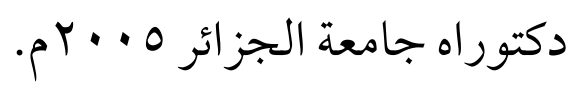
r/1 - النووي: صحيح مسلم بشرح النووي، تحقيق/ عصام الصبابطي، حازم محمد،

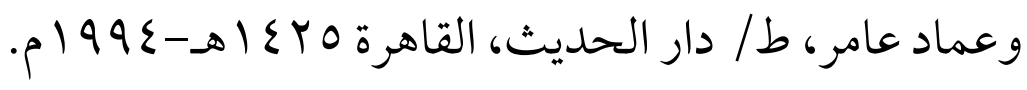
rی1 - -وجدي محيسن: مدى رضا الموظفين العاملين في مؤسسات وكالة الغوث في قطاع غزة عن أنظمة التعويض والحوافز، رسالة ماجستير، الجامعة الإسلامية

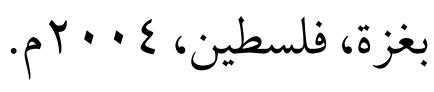




\section{فهرس الموضوعات}

$V \cdot r$

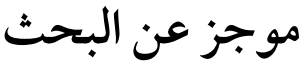

$V \cdot 0$

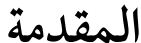

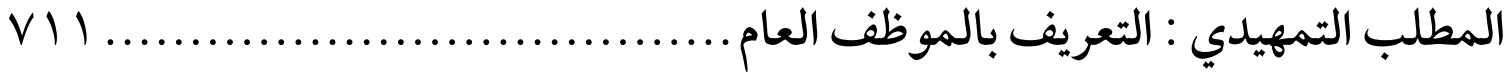

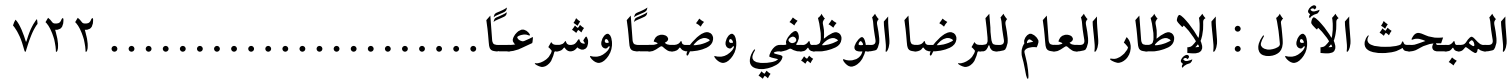

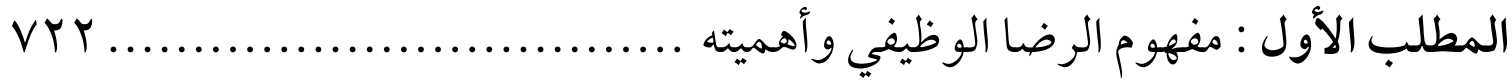
VYr الفرع الأول : تعريف الرضا الوظيفي VYV الفرع الثاني : أهمية الرضا الوظيفي VYr المطلب الثاني : أنواع الرضا الوظيفي وخصائصه. VYT. المطلب الثالث : العو امل المؤثرة في الرضا الوظيفي. المطلب الرابع : أساليب قياس الرضا الوظيفي ومظاهر تحقيقه ........................

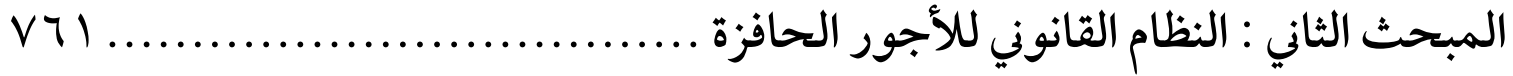

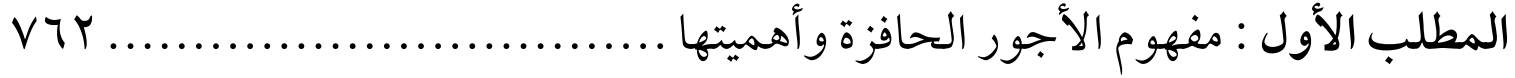

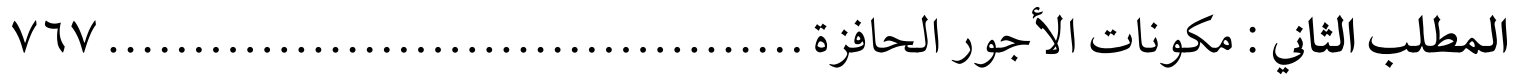
$\vee 79$ الفرع الأول : مكونات الأجور الحافزة في النظم الوضعية .

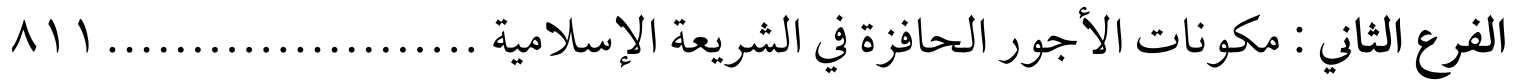

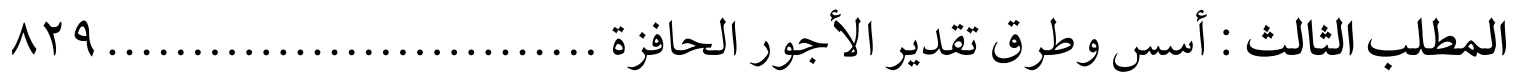
$\wedge \varepsilon 1$

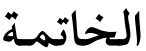
$\wedge \varepsilon 0$ قائمة بأهم مصادر البحث 